\title{
The historical earthquakes of Syria: an analysis of large and moderate earthquakes from 1365 B.C. to 1900 A.D.
}

\author{
Mohamed Reda Sbeinati $\left({ }^{1}\right)$, Ryad Darawcheh $\left({ }^{1}\right)$ and Mikhail Mouty $\left({ }^{2}\right)$ \\ ( ${ }^{1}$ Department of Geology, Atomic Energy Commission of Syria, Damascus, Syria \\ $\left(^{2}\right)$ Department of Geology, Faculty of Science, Damascus University, Damascus, Syria
}

\begin{abstract}
The historical sources of large and moderate earthquakes, earthquake catalogues and monographs exist in many depositories in Syria and European centers. They have been studied, and the detailed review and analysis resulted in a catalogue with 181 historical earthquakes from 1365 B.C. to 1900 A.D. Numerous original documents in Arabic, Latin, Byzantine and Assyrian allowed us to identify seismic events not mentioned in previous works. In particular, detailed descriptions of damage in Arabic sources provided quantitative information necessary to re-evaluate past seismic events. These large earthquakes $\left(I_{0} \geq \mathrm{VIII}\right)$ caused considerable damage in cities, towns and villages located along the northern section of the Dead Sea fault system. Fewer large events also occurred along the Palmyra, Ar-Rassafeh and the Euphrates faults in Eastern Syria. Descriptions in original sources document foreshocks, aftershocks, fault ruptures, liquefaction, landslides, tsunamis, fires and other damages. We present here an updated historical catalogue of 181 historical earthquakes distributed in 4 categories regarding the originality and other considerations, we also present a table of the parametric catalogue of 36 historical earthquakes (table I) and a table of the complete list of all historical earthquakes (181 events) with the affected locality names and parameters of information quality and completeness (table II) using methods already applied in other regions (Italy, England, Iran, Russia) with a completeness test using EMS-92. This test suggests that the catalogue is relatively complete for magnitudes $>6.5$. This catalogue may contribute to a comprehensive and unified parametric earthquake catalogue and to a realistic assessment of seismic hazards in Syria and surrounding regions.
\end{abstract}

Key words historical earthquakes - historical sources - seismic hazards - Dead Sea fault system Eastern Mediterranean - Lebanon - Syria

\section{Introduction}

The Middle East is one of the few regions worldwide where historical accounts of earth-

Mailing address: Dr. Mohamed Reda Sbeinati, Department of Geology, Atomic Energy Commission of Syria, P.O. Box 6091, Damascus, Syria; e-mail: sbeinati@scs-net.org quakes can date back several hundred years B.C. When available, historical earthquake records are a critical database for characterizing earthquake sources and assessing seismic hazards. Previous compilations of historically documented earthquakes in Syria and adjacent regions indicate noteworthy seismic activity with large damage (e.g., Sieberg, 1932; Ben-Menahem, 1979; Plassard and Kogoj, 1981; Guidoboni et al., 1994; Ambraseys and Jackson, 1998). Despite these invaluable contributions to the understanding of seismicity in the Middle East, considerable information has remained unexploited in numerous original sources that provide important and quantitative input for developing a parametric catalogue. 
Since 1990 and within the framework of the «Seismic Data for Siting and Site-Revalidation of Nuclear Facility» research project, under the patronage of the International Atomic Energy
Agency (IAEA), the Seismology Section in the Department of Geology and Nuclear Ores at the Atomic Energy Commission of Syria (AECS) has investigated the historical seismicity of Syr-

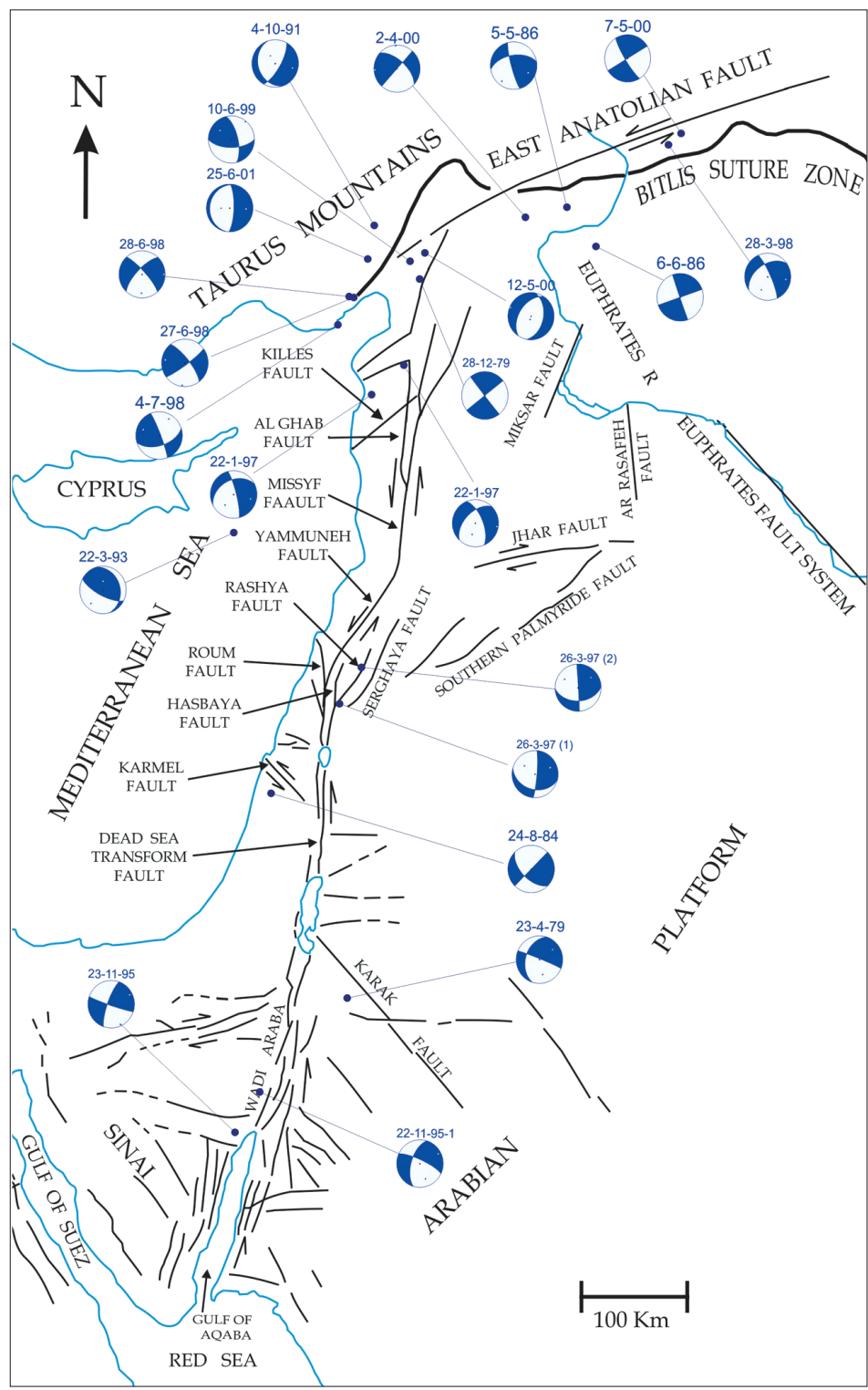

Fig. 1. Summary of major fault zones of the northern Arabian plate (redrawn from Garfunkel et al., 1981; Barazangi et al., 1993). 
ia. Original sources were identified, located, and exploited to extract the necessary information for constructing a unified parametric catalogue. We studied 181 historical earthquakes, and estimated the related intensities for each locality with a standardized methodology. A final parametric catalogue for 36 major earthquakes reports the epicenter locations, maximum intensities and estimated magnitudes.

This paper documents historical earthquakes of Syria and addresses the following points: i) the study of new historical seismic events; ii) the re-appraisal of historical seismic events in the light of original and new sources; iii) re-evaluation of past events by means of a careful examination of all available references; iv) historical earthquakes in previous works, and finally a discussion on the distribution of large earthquakes along the main fault systems. In addition, all events are listed in table II which represents complete information about the historical earthquakes with estimated intensities at relevant localities and accompanying effects, with information completeness (A - complete; $\mathrm{B}$ - accepted; $\mathrm{C}$ - incomplete) and information quality factors (1 - good source quality; 2 - moderate source quality; 3 - poor source quality).

\section{Seismotectonic setting}

The study area is located in the northern part of the Arabian plate and encompasses Syria and Lebanon and adjacent areas of neighboring countries. It is bounded from the west, by the northern section of the Dead Sea Fault system (DSF), a plate boundary consisting of the northeast trending Al-Yammouneh Fault (YAF) and the north trending Al-Ghab Fault (GAF) (fig. 1). Northeast of Antioch, the DSF intersects the Eastern Anatolian Fault system (EAF) and the Bitlis Suture zone (BS), both of which comprise the northern border of the Arabian plate. Between Damascus and the Euphrates River, the northeast trending Palmyra fold-thrust belt is located within the northern Arabian plate (fig. 1). This belt consists of many asymmetrical elongated anticlines separated by narrow depressions.

The seismicity of Syria can be qualified as moderate during the last century (fig. 2). However, the historical seismicity indicates the occurrence of large earthquakes in the past. The main instrumental seismicity with many moderate earthquakes $\left(5<M_{s}<6\right)$ is located along the East Anatolian Fault and the Dead Sea fault system (Sbeinati, 1993). An apparent lack of

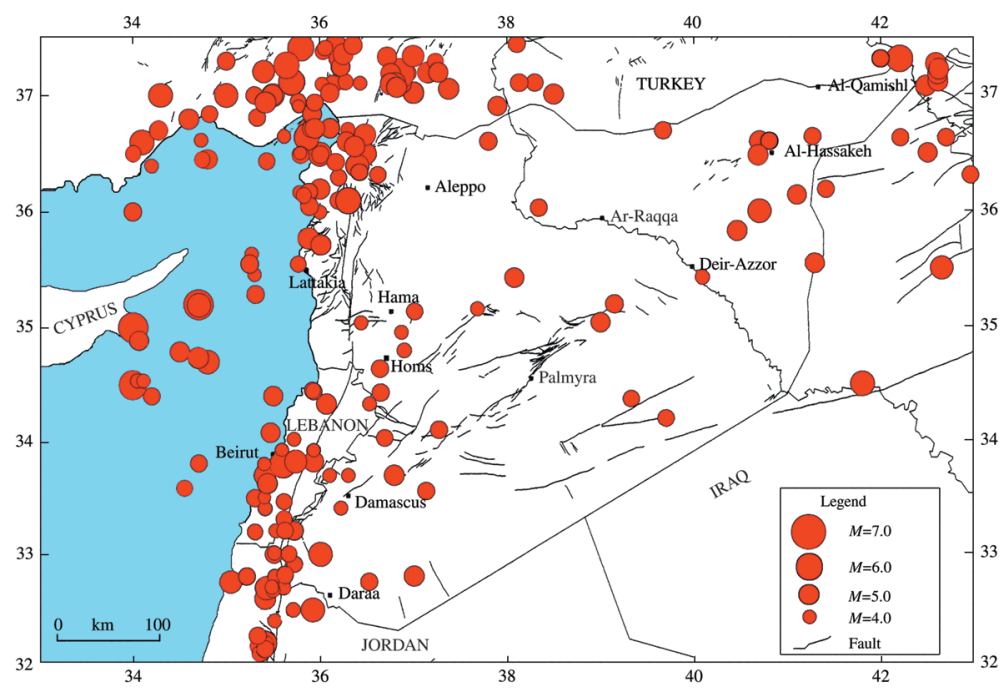

Fig. 2. Map of Syria showing the seismicity during 1900-1993 (Sbeinati, 1993). 
seismicity can be observed along the Ghab fault zone and motivates a careful analysis of seismic documentation of the region.

Focal mechanisms of the main recent events indicate a NNW-SSE trending of $P$ axes with strike slip movements along faults (see Harvard CMT Catalogue). These mechanisms illustrate the left-lateral pattern of active deformation with minor component of normal faulting associated with pull-apart basins along the Dead Sea Fault. The rate of active deformation and relative Arabia-Africa plate motion determined from GPS studies varies from 5.6 to $7.5 \mathrm{~mm} / \mathrm{yr}$ from south to north, respectively (McCluskey et al., 2003). Recent paleoseismic and archeoseismic investigations along the Missyaf segment south of the Ghab Basin show successive faulting with 13.6 $\mathrm{m}$ of left-lateral displacements during the last 2000 years yielding an average $6.9 \mathrm{~mm} / \mathrm{yr}$ slip rate (Meghraoui et al., 2003). In contrast, the intraplate area of Syria is generally aseismic, with infrequent earthquakes some of which can be of significant size $\left(M_{w} 5.5\right)$ (fig. 2).

\section{Previous works}

Earthquake catalogues of the Middle-East are from Hoff (1840), Mallet (1853) and Perrey (1850) who compiled a list of earthquakes (see the parametric catalogues and seismological compilations in References Section). Tholozan (1879) mentioned information about earthquakes that hit the Middle-East between 7th and 17th centuries; Willis compiled in 1928 and 1933 (Willis, 1928, 1933a,b) an earthquake list for Palestine; catalogue of Sieberg (1932) is a global work with an incomplete description; Amiran prepared in 1950-1951 and 1952 a revised catalogue of Willis' work; Ergin et al. (1967) presented a parametric earthquake catalogue for Turkey and surrounding areas between 11 A.D. and 1964 A.D.; Al-Sinawi and Ghalib (1975) compiled a detailed and descriptive earthquake catalogue of Iraq and partly some adjacent countries using modern references; the parametric catalogue of Ben-Menahem (1979) is a real attempt at parameterization of the historical earthquakes specifically concerned with the Middle East; Taher (1979) presented a full corpus of texts from
Arabic sources about the earthquakes that hit the Arab World; the work by Plassard and Kogoj (1981) is generally related to Lebanon and Syria; Russell (1985) used the available ancient textual and archaeological data in order to compile the seismic events of Palestine, Lebanon and Syria between the 2nd and the mid-8th century; Ambraseys et al. (1994) offered a seismic catalogue for Egypt, Arabia and the Red Sea; work of Guidoboni et al. (1994) represents a critical compilation and a historical review on the historical earthquakes that hit the Mediterranean area; Ambraseys and Finkel (1995) compiled a catalogue for Turkey and adjacent areas for the period 1500-1800; finally the compiled catalogue on Lebanon and parts of Syria presented by Abu Karaki (1992) is not based on primary sources.

On the other hand, there are two detailed papers dealing with the 1202 A.D. earthquake in the Eastern Mediterranean region (Ambraseys and Melville, 1988) and 1759 A.D. earthquake in Bekaa Valley (Ambraseys and Barazangi, 1989).

Although some of these catalogues consist of many usual and unusual problems, they are, to a large extent, valuable and helpful for preparing our catalogue.

\section{Sources of the catalogue}

Syria has been home to some of the world's earliest civilizations. It is located on the eastern shore of the Mediterranean Sea, at the crossroads of three continents (Asia, Europe and Africa).

The main sources for the pre-Islamic period are official letters, accounts of travelers who visited the affected regions shortly after the earthquakes, diaries, chronicles of historians written in Syriac and Greek. Most of these sources are not available in Syria. The rise of Islam in the early 7th century in Mecca, followed by many conquests for Syria and other regions represented the first step for real systematic documentation in the region. The Muslims paid considerable attention to the history of the Islamic World. Earthquakes are among natural phenomena that attract Muslim historians. Arabic chronicles are one of the main primary sources for the history of earthquakes for our region, from the 9th century till the 19th centu- 
ry. Between the 7th century and 1000 A.D., there were universal chronicles covering various events that happened in the Islamic Empire. Then and due to many known reasons, history was written to be more local. By the 17th century, the European sources started to mention events of our region in the form of travel literature and diplomatic correspondence reports. These latter were preserved in archives in Europe and Turkey.

An extensive bibliographical research has been performed as a base step and continued throughout the research period in order to dynamically improve the result (see References Section).

Scientific visits to the Turkish Atomic Energy Authority, Ankara, and ENEA, Rome, were made in 1994 and 1995, in an attempt to collect available sources and to better understand the methodology of studying historical earthquakes where many important historical sources on Byzantine and Ottoman eras were found.

Our investigations were achieved in the following libraries: Al-Assad National Library in Damascus, Syria (this cultural center represents one of the largest depositories in our Arabian region, containing a huge number of histories, mother books); the Institut Français de Damas in Damascus; Süleymaniye Library in Istanbul; the National Library in Ankara; the Vatican Library in Rome (by Dr. C. Margottini); Library of Pontificio Istituto Orientale in Rome (by Dr. C. Margottini).

There are numerous sources used for preparation this catalogue, these are original documents such as manuscripts, diaries, ambassador letters, existing catalogues and modern papers. To retrieve data already available in seismological literature, a supplement of research was devoted to a systematic reading of most sources.

Due to our belief that they are good interpretations, parameters of 1202 and 1759 events have been considered by this research as they are.

\section{Methodology}

For the study of historical earthquakes in and around Syria, all available relevant information concerning the history in the region was collect- ed from libraries in Syria, Turkey, Lebanon and Italy. This information is translated, when needed, to the English language. Then, this information is assessed and evaluated. In addition, all other catalogues, monographs and books were also searched.

Both occidental and oriental sources containing useful data about earthquakes during the years under consideration have been identified, particularly Arabic, Greek, Syriac and to a lesser extent English, French and Ottoman.

Arabic chronicles are one of the main sources of information for the present catalogue, and they generally date earthquakes according to the Muslim calendar of 12 lunar months. The Muslim Era started in 622 A.D. (date of migration of the Prophet Muhammad from Mecca for Medina). Therefore, it is called the Hijiri (migration) calendar, which is indicated here by the suffix A.H. (i.e. After Hijira). In all cases, Gregorian calendar comes in the heading, while the Hijiri one is sometimes mentioned in the second part. On the other hand and for the sake of consistency, all needed conversions from Hijiri into their corresponding dates in the Christian calendar were made from the comparative tables in Wolseley Haig (1932) which takes 16 July 622 A.D. as the start of the Muslim Era. The Arabic documents are not without internal problems. As becomes clear below, the exact date of a earthquake is only rarely given in Arabic documents.

In principle, the applied methodology in this research is in accordance with the topology presented by the IAEA (1987) and by Stucchi (1994) as follows:

- Identifying the historical sources of information: historical sources (contemporary and near-contemporary), previous catalogues (parametric and compilations) and monographs have been investigated and collected from many libraries in Syria, Lebanon, Turkey and Italy.

- Grouping all available information relating to one historical earthquake and arranging it in chronicle order.

- Reading descriptions for each event in order to build up the earthquake flow and its date. Those descriptions which belong to the same event have been interpreted in terms of intensity for each affected locality using the European Macroseismic Scale 1992. 


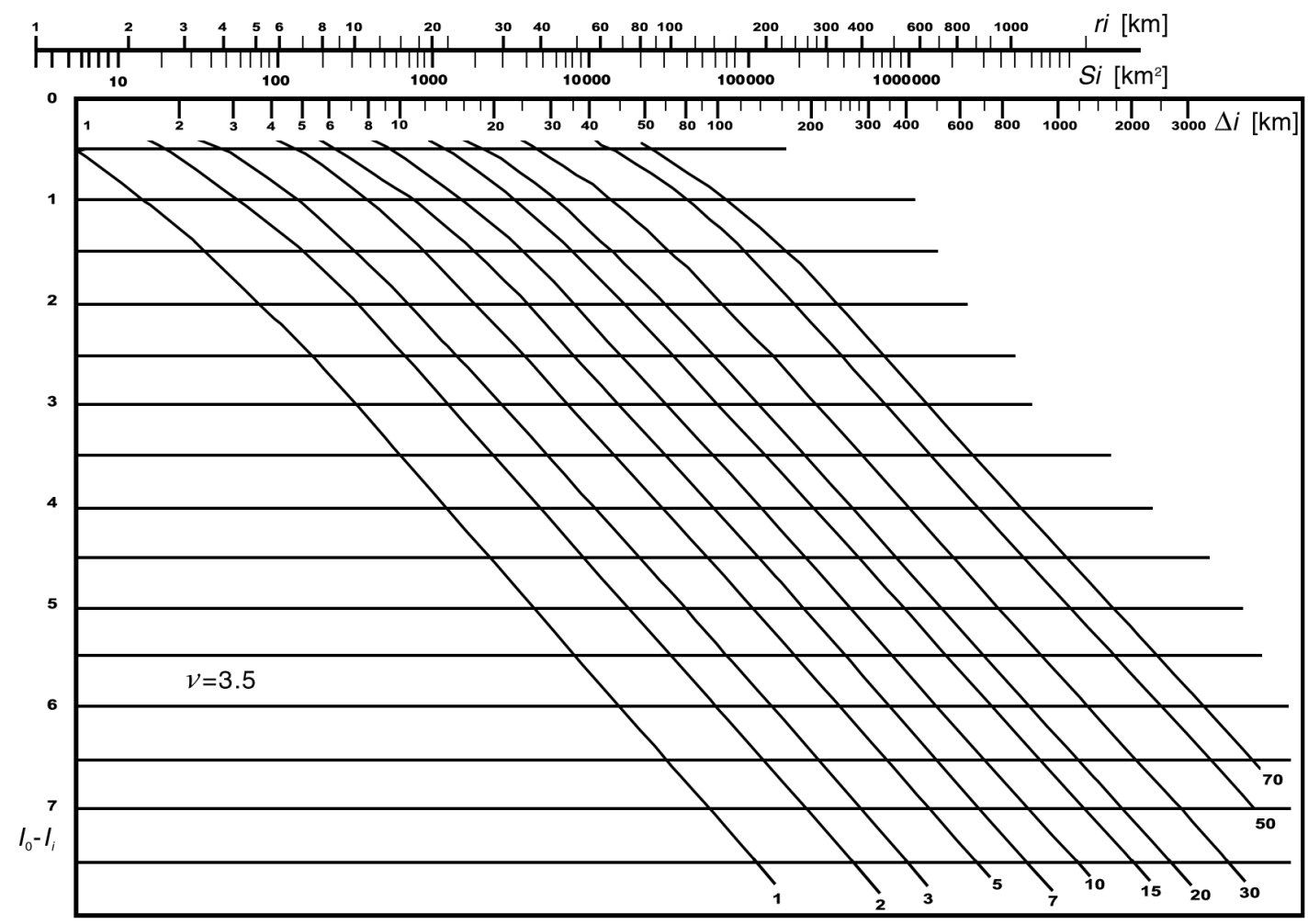

Fig. 3. Standard nomograph for determining local depht of shallow earthquakes from macroseismic data (area of isoseismal $\mathrm{Si}$, their average radius $r i$, or distance to points of known intesity $\Delta i$ ), for attenuation coefficient $v=3.5$ (Shebalin, 1970).

- Assessing parameters of each historical earthquake (date, epicentral location, epicentral intensity, locality intensity, depth and macroseismic magnitude), when the available descriptions are adequate to permit accurate assessment.

Date - Date of the earthquake is the first parameter that should be assessed. Date of the earthquake was assumed to be the most reliable one according to the nearest historical sources to the event in space and time.

Location - Latitude and longitude of the epicenter of the earthquake is the second parameter that should be also assessed. For the large earthquakes, this location was defined as a center of the isoseismal lines. However, all sources utilized in the catalogue give some idea of the location, with the indication of the area worst affected. In some cases, one locality was men- tioned, so there is only a choice of locating the earthquake near this center. In other cases, two or more localities are reported, so there is a good chance for locating the epicenter in between.

Intensity - Effects of any earthquake on the environment should be evaluated using any descriptive scale. In our case, epicentral intensity $\left(I_{0}\right)$ and intensities for each affected locality for the same earthquake have been assessed in accordance with the EMS Scale 1992. It is worth mentioning that the assessment of the intensity for each locality was defined on the basis of analyzing all sources taking into account their quality.

Depth - Depth of the earthquake foci can be evaluated when intensities of many localities are available. However, this assessment was performed according to the transparency of Shebalin (1970), with $v=3.5$ where $v$ is coefficient 


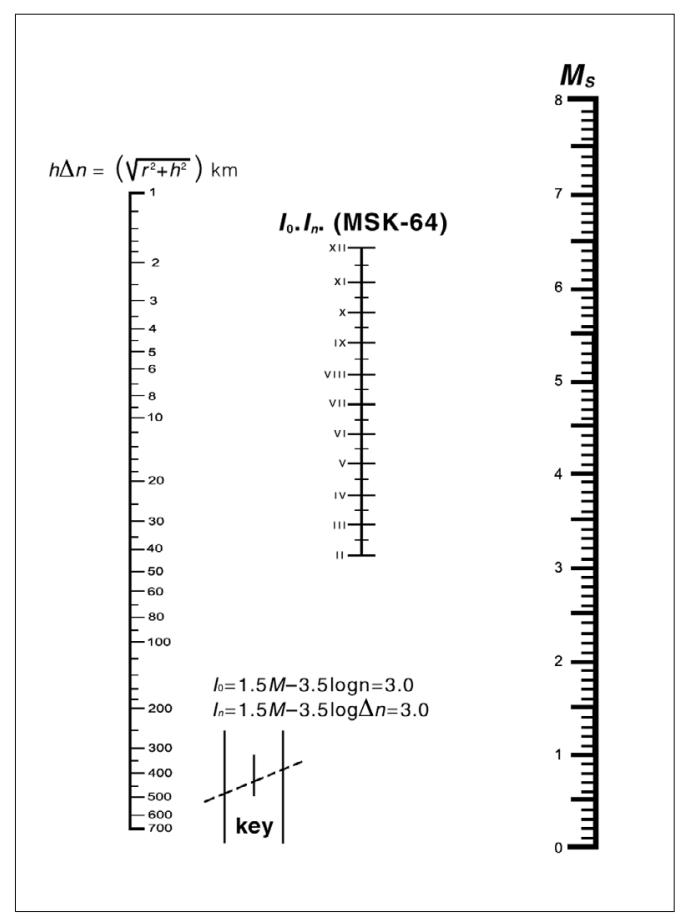

Fig. 4. Standard nomograph of $M, h, \Delta$ and $I$. It is averaged for shallow earthquakes $(b=1.5, v=3.5$, $c=3$ ) (Shebalin, 1970).

of intensity attenuation (fig. 3). It is worth mentioning that the tectonic setting of western boundary of the Arabian plate (transform system) suggests that earthquakes originating in the study area are shallow events within the crust $(44 \mathrm{~km})$.

Magnitude - Size of the earthquake is the most important parameter that should be calculated. For large events in the catalogue, it is derived using the nomograph proposed by Shebalin (1970) (fig. 4).

\section{Catalogue of historical earthquakes}

This catalogue contains all historical earthquakes affecting Syria and neighboring regions, the 181 events distributed in four categories regarding the following parameters: 1) new sources for past unknown 14 events; 2) re-appraisal of 42 historical seismic events in the light of original and new sources; 3 ) re-evaluation of 116 seismic events; and 4) contains 9 historical seismic events without re-evaluation.

\subsection{New sources for past unknown events}

In this section, we present unknown historical earthquakes and their associated original sources which has never been referenced elsewhere. These references correspond to Arabic sources collected from different depositories.

〈004〉 331 B.C. Syria: VI.

Sources

- Al-Boustani (1887): In the year of 331, there was a heavy earthquake causing many victims and destruction in Syria.

$\langle 069\rangle 1046$ July 8-1047 June 27 Diyar Bakr: z VII; Khlat: $\geq$ VII.

Sources

- Al-Suyuti: In the year 438 A.H. (1046 July 81047 June 27) many earthquakes occurred in Khlat and Dyar Bakr destroying the citadels and the fortresses, and killing people.

〈073〉 1094 April 20-May 18 Damascus: V-VI. Sources

- Ibn Al-Athir: In this month, 487 Rabi' II A.H. (1094 April 20-May 18), there was a sequence of earthquakes in Bilad Al-Sham for a long time without a significant damage.

- Al-Dawadari: In this year there were 12 shocks for one day, causing destruction of the country and killing a great scientist [at Damascus].

\section{〈081〉 1140 August 17-1141 August 6 Qalaat} Sheizar: VI-VII.

Sources

- Al-Dawadari: In this year [535 A.H.] [1140

August 17-1141 August 6] there was an earthquake in Sheizar, causing damaging its citadel.

\section{〈111〉 1537 March 08 Damascus: IV. Sources}

- Al-Ghazi: A slight shock was felt in Damascus on 27 Ramadan 943 A.H. (08 March 1537) (Badr Al-Ghazi). 


\section{〈113〉 1563 September 13 Damascus: VI.} Sources

- Al-Ghazi: A strong shock hit (Damascus), accompanied by a sound from the earth, on Sunday early morning, 24 Muharram 971 A.H. (13 September 1563), causing a few houses to collapse and many fractures to appear on walls (Badr Al-Ghazi).

$\langle 117\rangle$ 1604 March 13 Damascus: V; Bekaa: V. Sources

- Al-Nablsi: A strong shock was felt in Damascus and Bekaa on Friday night, 11 Shawwal 1012 A.H. (13 March 1604) (Al-Ghazi).

\section{$\langle 118\rangle 1606$ October 19 Baalbak: IV.}

Sources

- Al-Nablsi: A shock was felt in Baalbak on Monday night, 17 Jamada II, 1015 A.H. (19 October 1606) (Al-Ghazi).

\section{〈121〉 1618 July 8 Damascus: IV.}

Sources

- Al-Nablsi: A slight shock was felt [in Damascus] on Wednesday 15 Rajab 1027 A.H. (08 July 1618) at sunset time (Al-Ghazi).

〈122〉 1618 July 23-August 21 Damascus: IV. Sources

- Al-Nablsi: A slight shock was felt [in Damascus] in Sha'ban 1027 A.H. (23 July-August 21, 1618) (Al-Ghazi).

$\langle 123\rangle 1619$ December 8-1620 November 25 Darkoush. Landslide.

Sources

- Al-Nablsi: A landslide, probably resulting from an earthquake, happened in Darkoush in the year of 1029 A.H. (1619 December 08-1620 November 25), destroying many houses and killing about 70 persons (Al-Ghazi).

\section{$\langle 125\rangle 1627$ November 24. Damascus: V.} Sources

- Al-Nablsi: A strong shock hit Damascus on Wednesday night, 15 Rabi'I 1037 A.H. (24 November 1627), but without any damage (Al-Ghazi).

〈131〉 1683 Safineh. Landslide.
Sources

- Al-Nablsi: An earthquake occurred in a night of 1095 A.H. (1683), causing a village called Safineh in Al-Shouf region (Lebanon) to shift with its houses and trees from its location on the top of the mountain to the bottom of the valley, but without any damage.

\section{$\langle 135\rangle 1712$ December 28 Damascus: IV. Sources}

- Al-Nablsi: He reported that a shock was felt in Damascus on Wednesday night, $29 \mathrm{Zu}-1-\mathrm{Qa}^{-}$ da 1124 A.H. (28 December 1712).

\subsection{Re-appraisal of historical seismic events in the light of original and new sources}

The seismic events of this section have already been mentioned in previous works, but original documents and new sources of information (most of them from the Arabic and Byzantine period) provide new information on earthquake size and related damage distribution. Therefore, for some large events we provide a special section on «Sources» added to the «Parametric catalogues and previous studies» and «Seismological compilations».

$\langle 001\rangle \sim 1365$ B.C. Ugharit: VIII-IX. Tsunami, fire.

Sources

- Schaeffer (1948): A violent earthquake hit Ugharit in the Recent Bronze Era between 1370 and 1360 B.C. (probably in 1365 B.C.). The layer of destruction that found in level I of Ugharit represents archaeological evidence for the catastrophe. Preliminary investigation in Ugharit permited that this layer caused by 1365 B.C. earthquake is corresponded with the text found in Tell Al-Amarneh in Syria, which was reported by Abimilki of Tyre to Amenophis IV as follows: «Ugharit, city of the king, was destroyed by the fire; half of the city burnt, other half was intact». Schaeffer estimated the intensity of this earthquake at Ugharit to be VIII after Mercalli scale or IX-X after the international scale. Detailed regional studies allow the establishment of the layers of destruction that found in Beit Mirsin, level CI, Recent Bronze II of Jerico and 
probably those of Megiddo VIII, Bissan VII, Hésy V, Ascalan V ... were a result of the same earthquake of Ugharit. Farther away, the site of Troie in Asia Minor was subjected to serious damage due to an earthquake in the middle of XIV century (American excavations). In the center of Asia Minor, Boghazkeuy-Hattousas, the capital of Hittites was subjected to serious destruction during the time of 1365 B.C. earthquake.

- Saadeh (1982): A possible earthquake was in Ugharit. It was accompanied by a high seawave covered the region of Minet Al-Biada, and with a fire (indicated accidentally in a letter from the King of Tyre «Abimilki» to Pharoa of Egypt and archaeological excavation in Ugharit according to Schaeffer, 1954).

Parametric catalogues

- Plassard and Kogoj (1981): 1365 B.C., I=X, destruction in Ugharit and Byblus (A letter from a King of Tyre to Akenton Pharoa).

- Ben-Menahem (1979): In 1356 B.C., destruction of Ugarit, with tsunami at the Syrian coasts. Other works

- Klengel (1985): Between 2100 and 1200 B.C., there was a catastrophe in Ras-Shamra (Ugharit) transferring the flourishing city into ruins and ash.

$\langle 006\rangle$ 148-130 B.C. February 21, afternoon Antioch: $\geq$ VII.

Sources

- Al-Boustani (1887): 115 B.C., it was a heavy earthquake and many victims in Antioch.

Parametric catalogues

- Ben-Menahem (1979): 184, $M_{l}=6.8$, an earthquake was near Antioch (Willis).

Seismological compilations

- Sieberg (1932): 148 or 184, a destructive earthquake in Antioch.

- Guidoboni et al. (1994): Antioch IX $\leq I \leq X I$, Antioch was suffered from the wrath of God. It could be dated at the year 130 B.C. (Malalas) regarding the confusion in Malalas dating or there were two separate earthquakes.

- Sieberg (1932): 140 B.C., a destructive sea wave was along the Syrian coast.

$\langle 032\rangle 502$ August 22, Friday Akka: VIII; Tyre: VII-VIII; Sidon: VII-VIII; Beirut: VII; Palestine: VI; Safad: VI?; Reina: VI?

\section{Sources}

- Joshua the Stylite: 502 August 22, Friday: Ptolemais destroyed to the extent that nothing stayed standing. Half of Tyre and Sidon fell down. In Beirut, only the synagogue fell down.

Parametric catalogues

- Plassard and Kogoj (1981): 502 August 2122 , in Lebanon $I=\mathrm{IX}$, half of Tyre and Sidon were destroyed, at Beirut ( $I=$ VII) some damage in houses, remarkably in the synagogue (Joshua the Stylite).

- Ben-Menahem (1979): 502 August 21 off coast Acre, $I_{o}=\mathrm{X}, M_{l}=7.0$, Acre destroyed. Destruction at Sur, Sidon, Beirut and Byblos. Latrun (Nicopolis) destroyed (Amiran; Plassard and Kogoj).

\section{Seismological compilations}

- Guidoboni et al. (1994): 502 August 22, Akka $I=\mathrm{X}$, an earthquake happened between 501 and 502, where Akka was overturned and destroyed completely, half of Tyre and Sidon fell, the synagogue in Beirut fell down (PseudoJoshua's Chronicle). Palaces in Palestine were also affected (Russell).

- Russell (1985): 502 August 22, Akko was overturned by an earthquake at night and nothing left standing. Half of Tyre and Sidon fell. The synagogue at Beirut fell down (Chronicle of Joshua the Stylite). Safad and Reina in Galilee could be affected.

〈034〉 526 May 20-29 Antioch: VIII; Dafneh: VII; Seluecea: VII. Aftershocks. Liquefaction at Antioch. Fire in Antioch.

Sources

- Malalas (1831): A large catastrophe occurred in Antioch. Citizens were buried under the debris. The houses, located only near the mountain, survived. The rest of the buildings were completely destroyed. Fire following the earthquake destroyed the Big Church (so was named the ancient church of Antioch) and the remaining houses. There were 250000 casualties because of holidays. Shocks lasted 18 months. Some buildings in Selucea and Dafneh fell down.

- John of Ephesus: In Antioch, the disaster was on the 7th hour, fire from the land and sky. City wall, houses and churches were destroyed. There was a fire following the earthquake. The Big Church was burned after 7 days and de- 
stroyed completely. There were 255000 casualties ... as Malalas.

- Procopius of Caesarea: A severe earthquake occurred in Antioch where most of the buildings and the most beautiful ones fell down. There were 300000 casualties.

- Evagrius Scholasticus: An earthquake, followed by a fire, occurred in Antioch.

- Chronicon Edessenum (Urfa): A great earthquake ruined Antioch.

- Zachariah of Mitylene: A severe earthquake in Antioch. Houses fell down over their inhabitants.

- Giovanni Lido: The earthquake split Antioch and Selucea, no damage to the desert place between the mountain and the city where runs the river of Orontes.

- Marcellinus Comes: A severe earthquake destroyed Antioch. The fire, following the earthquake, increased by the wind.

- John of Nikiu: An earthquake and a fire were in Antioch. Houses were completely destroyed as well as a house located on the nearby hill. Many churches were destroyed or divided in two parts from the bottom to the top. The Big Church was destroyed. The casualties were 250000. Towns of Dafneh and Selucea at 20 miles from Antioch were destroyed.

- Theophanes: A large part of Antioch was destroyed by the earthquake. The survived citizens were killed by the fire.

- Chronicle of 819: A severe earthquake. Antioch was destroyed. The casualties were 255000 .

- Georgius Monachus: An earthquake and a fire were in Antioch. There were many casualties.

- Leo Grammaticus: Most of Antioch was destroyed by the earthquake and fire.

- Georgius Cedrenus: There was an earthquake, followed by 6 days fire. There were many thousands of casualties.

- Michael Glykas: The earthquake produced a big opening. The fire killed the survivors.

- Chronicle of 1234: An earthquake and a fire occurred in Antioch, destroying all buildings and churches.

- Girgis Bar Hebraeus: An earthquake occurred in Antioch. The casualties were 255000. Shocks continued for one year and six months.

Parametric catalogue

- Plassard and Kogoj (1981): 526 May 29, in
Lebanon $I=\mathrm{V}$, Antioch was destroyed for the fifth time with a large number of victims (Michael the Syrian).

- Poirier and Taher (1980): 526 May mid-day 20-29, $I_{0}=\mathrm{IX}-\mathrm{X}$ (MMS), very severe earthquake in Antioch.

\section{Seismological compilations}

- Guidoboni et al. (1994): 526 May mid-day 2029 , Antioch $I=\mathrm{X}$, a disastrous earthquake was at Antioch, causing a great fire and thousands of deaths. There were fire and liquefaction resulted by the earthquake at Antioch, and everything had been destroyed, 250000 people perished (Malalas). Much of Antioch collapsed and vast numbers of people were killed (The Chronicle of Zacharia of Mitylene). Dafneh was struck by a violent earthquake which reduced the whole city to ruins and three hundred thousand Antioch perished (Procopius of Caesarea).

- Sieberg (1932): In 526, a strong earthquake, followed by a fire, destroyed Antioch with 250000 deaths (?). In Seleucea, there was damage.

\section{〈035〉 528 November 29 Antioch: VII-VIII;} Lattakia: VI-VII.

Sources

- Malalas (1831): in Antioch, duration one hour, terrible rumbling, all buildings which were rebuilt fell down, as well as the city wall and some churches. Damage to other cities near Antioch, with 5000 casualties. In the same year, Laodicia had the first earthquake, where its half was destroyed with 7500 casualties, the synagogue fell down but the church did not.

- John of Ephesus: A terrible earthquake with rumbling, ... as Malalas as well as the city gate fell down. The Big Church fell down and all the surviving houses and churches from the previous earthquake fell down except few numbers of buildings, villages in the vicinity 10 miles were destroyed. Seleucea and Dafneh did not affect. Surviving citizens of Antioch ran away to the open. In the 529 Laodicia was completely destroyed from the gate of Antioch to the Ghetto, but the left zone east of the church of S. Mother of God did not fall down, there were 7500 casualties without a fire.

- Evagrius Scholasticus: The earthquake split Antioch.

- Theophanes: A strong earthquake lasted for one 
hour with terrible sound such as a bull's sound, all the constructions, the city wall and old constructions which survived from the previous earthquake fell down, there were 4870 casualties. - Georgius Monachus: One hour duration, sound, the area 5 miles around Antioch fell down.

- Leo Grammaticus: An earthquake at Antioch.

- Georgius Cedrenus: A large earthquake lasted for one-hour duration, there was a terrible sound, all constructions were destroyed with 4870 buried casualties, emigration of survivors. - Chronicle of 1234: There was a severe earthquake, followed by a sound from the sky like thunder and a sound from the earth like a bull's sound. City walls, churches and the surviving constructions from the previous earthquake were destroyed as well as the vicinity villages, there were 2740 casualties.

- Nicephorus Callistus: A severe earthquake at Antioch.

- Saadeh (1984): 529 January 2, a violent earthquake occurred in Lattakia, causing destruction of its large part and killing 7500 people.

Parametric catalogues

- Plassard and Kogoj (1981): 529 November 29 , in Lebanon $I=I V$, Antioch was destroyed for the sixth time (Cedrenus; Michael the Syrian).

- Poirier and Taher (1980): 528 November 29, $I_{0}=\mathrm{X}-\mathrm{XI}$ (MMS), Antioch, a mountain fell into the Euphrates at Quludhya, the Euphrates shifted its bed.

- Ben-Menahem (1979): 528 November 29, $M_{l}=6.9$, destruction of Antioch. Damage in Jerusalem and Damascus. Felt in Egypt, Turkey, Armenia and Mesopotamia (Ergin et al.; Plassard and Kogoj; Sieberg).

Seismological compilations

- Guidoboni et al. (1994): 528 November 28, Antioch and Lattakia $I=I X$, an earthquake struck Antioch destroying both the new buildings put up after the previous one (526), and those old buildings which had survived it, victims number was few thousands. Antioch suffered from an earthquake collapsing the new buildings, walls and some of churches, from one side and killing up to 5000 lives (Malalas). Laodicea suffered its first earthquake disaster by destroying its half and 7500 deaths (Malalas). Antioch was subjected to a violent earthquake causing all the buildings and walls to collapse (Theophanes).
- Sieberg (1932): In 528 November, a destructive earthquake was in Antioch, Dafneh and Betelma (?). There was damage in Seuleucea, Loadicea and Pompejopolis (?). In the latter, surface rupture appeared. There were 4870 victims.

\section{〈036 531-534 Area between Aleppo and} Homs: VI-VII; Antioch: VI; Mesopotamia: IV. Sources

- Malalas (1831): (earthquake between 531534) After a short time, a terrible earthquake occurred at Antioch, but without damage.

Seismological compilations

- Sieberg (1932): 532, a destructive widespread earthquake in Syria. It destroyed the area from Aleppo to Homs. It was said that 130000 were killed. It was felt in Mesopotamia.

- Guidoboni et al. (1994): 532, An earthquake in Antioch without damage (Malalas). It dated back to between 531 and 534 (Downey, 1961).

〈037〉 551 July 9 Beirut: IX-X; Sur: IX-X; Tripoli: IX-X; Byblus: IX-X; Al-Batron: IXX; Shaqa: IX-X; Sarfand: VII-VIII?; Sidon: VII-VIII; Arwad: III-IV. Tsunami along the Lebanese coast. Landslide near Al-Batron. Fire at Beirut (fig. 5).

New original sources

The following publication summarizes the main information with new original sources on the earthquake of Beirut.

- Darawcheh et al. (2000): 551 July 9, 34.00N$35.50 \mathrm{E}, M_{s}=7.2$. This event destroyed several cities in Lebanon (Beirut, Tripoli, Saida, Djbil, Al-Batron, Tyre, Shakka and Sarfand) with great loss of lives. The shock was felt throughout the Eastern Mediterranean region. There were tsunami along the Lebenese coast, a local landslide near Al-Batron and a large fire in Beirut.

Among the main original references we mention: - Theophanes: A large and terrible earthquake took place in the territories of Palestine, Arabia, Mesopotamia, Syria and Pheonicia. Tyre, Sidon, Beirut, Tripoli and Byblus suffered much damage and many thousands of people were killed. A part of the mountain named Lithoprosopus fell down forming a harbor in Botro, the sea went back for 1000 feet and many ships sunk.

- Georgius Monachus: A large and widespread 


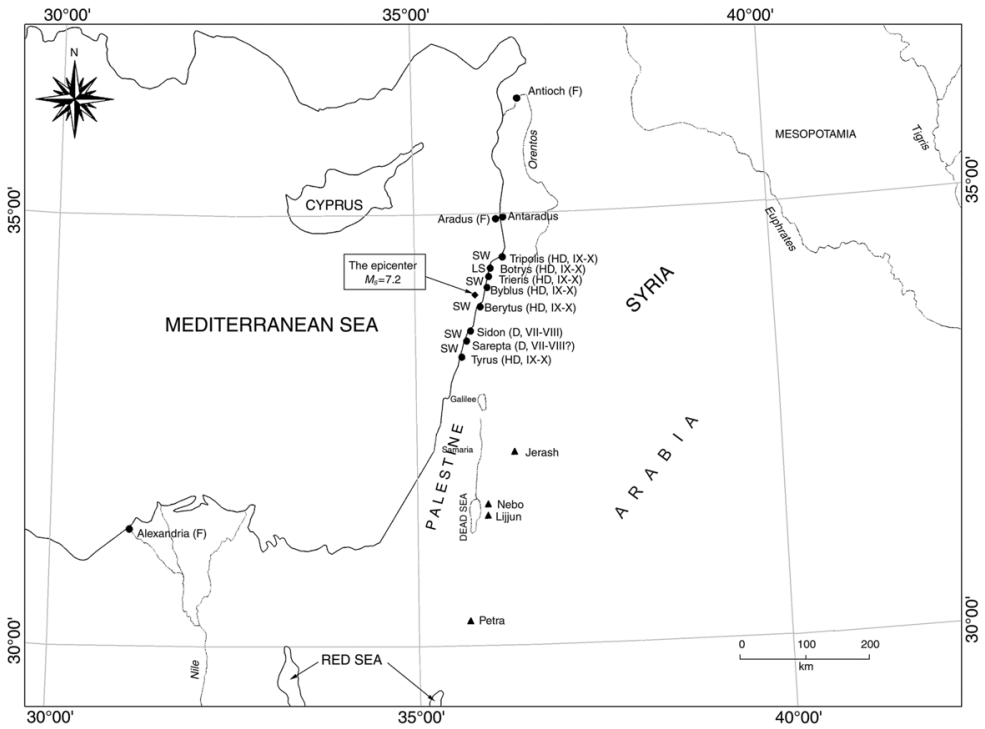

Fig. 5. Map of intensity distribution for July 9, 551 A.D. earthquake. F - felt; D - damage; LS - landslide, and SW - Sea-Wave. Triangles represent possible damaged archaeological sites (Darawcheh et al., 2000).

earthquake. Most of the Earth shocked. The sea went back for two miles. This event caused destruction in Arabia, Palestine, Mesopotamia, Antioch and many others and near cities, killing large numbers of people.

- Georgius Cedrenus: A big earthquake destroyed houses, churches and the most part of the city wall near the Golden Gate. The sea went back for two miles. In Arabia, Palestine, Mesopotamia, and Antioch, many villages were destroyed. The earthquake destroyed most part of Nicomedia. Shocks continued for 40 days.

Parametric catalogues

- Plassard and Kogoj (1981): 551 July 6, in Lebanon $I=\mathrm{XI}$, an earthquake caused destruction of Beirut $(I=\mathrm{XI})$, Tripoli $(I=\mathrm{X})$, Sidon and Tyre $(I=$ VIII or IX) and 101 sites, a landslide occurred in the Lithoprosopon Mountain near Ras Chekka, Wujj Al-Hajar, creating a harbour near Al-Batron, there was a tsunami in Beirut and Tripoli in particular, where the sea retreated for two miles (Agathias; Fragment of Tusculum).

- Ben-Menahem (1979): 551 July 09, off coast Beirut, $I_{0}=$ XI-XII, $M_{l}=7.8$, destruction of Beirut, Sur, Sidon, Tripoli and Galilee. Felt in
Egypt, Arabia and Mesopotamia. Tsunami. (Amiran; Al-Sinawi and Ghalib; Plassard and Kogoj; Sieberg; Willis).

Seismological compilations

- Guidoboni et al. (1994): 551 July 9, the earthquake affected the following localities: Byblus, Beirut and Tripoli $I=\mathrm{X}$, Sidon, Botrus (Al-Batron), Tyre, Arabia, Mesopotamia, Palestine and Syria, seismic sea wave and landslide, the principal damage was between Antioch and Tyre whereas there was apparently only minor damage further north and south. A disastrous earthquake along the Lebanese coast reducing many cities to ruins: Tripoli, Byblus, Beirut, Triaris, and killing thirty thousand known people in Beirut (Antoninus of Piacenza). A severe and tremendous earthquake occurred throughout the land of Palestine, in Arabia and in the land of Mesopotamia, Antioch, Phoenice Maritima and Phoenice Libanensis including Tyre, Sidon, Beirut, Tripoli, Byblus and parts of other cities, killing large numbers of people, cutting a large part of Lithoprosopon mountain at Botrus and accompanyied by a seismic sea wave (John of Ephesus; Malalas; Theophanes). Beirut was 
completely ruined and many inhabitants were crushed to death under the weight wreckage (Agathias). It dated back to 557 (Michael the Syrian).

- Ambraseys et al. (1994): 551 July 9, 32.0N$36.0 \mathrm{E}, I \leq \mathrm{VI}$, tsunami.

- Russell (1985): 551 July 9, a disastrous earthquake occurred throughout the regions of Palestine, Arabia, Mesopotamia, Syria and Phoenicia, to such an extent that Tyre, Sidon, Beirut, Tripoli and Byblus received great damage, and many thousands of people perished. In Botryos, a large part of the mountain called «Lithoprosopus» near the sea was separated and displaced into the sea. The water also withdrew for a mile out to a sea (Theophanes). Same description was mentioned by Cedrenus, but dated this event between $\mathrm{Au}$ gust 550 through July 551. Agathius described the extensive damage to Beirut, without providing an exact date for this earthquake. He mentioned that this event was felt in Alexandria. Sites in the eastern delta may have been damaged, particularly Damieta.

- Sieberg (1932): 551 July 9, a vast earthquake occurred in Syria, Palestine, Egypt, Arabia and Mesopotamia. Beirut was completely destroyed with many deaths. It was said that 600 persons were buried under the debris. There was damage in the coastal cities between Tripoli and Tyre. Antioch, Apamea, Bosra and Alexandria were among the cities destroyed. The sea waves destroyed a large number of ships, especially in Botrys.

$\langle 040\rangle$ 565-571 Antioch: VI-VII; Seleucea: VI-VII; Kilikia: VI; Anazrabo: VI; Orfa: IV. Sources

- Procopius of Caesarea: Earthquakes destroyed Antioch and near Selucea.

- Theophanes: A severe event took place in Cilicia, Anazarbo, and Antioch.

- Georgius Cedrenus: A plague and earthquake occurred in Cilicia, Anazarbo and Antioch.

Parametric catalogues

- Ben-Menahem (1979): 565, $M_{l}=6.7$, strong in Baalbak and Damascus. It was felt in Palestine and Mesopotamia (Sieberg; Willis).

Seismological compilations

- Guidoboni et al. (1994): 570, a violent earthquake affected Antioch IX $\leq I \leq X I$, Anazarbus, Edessa, Samosata, Seleucea Pieria, Cilicia and
Syria. It is possible that there where two distinct earthquakes, but it is more likely that the date 570 is the result of confusion on the part of James of Edessa. A severe earthquake on 5 October with sound (Elias of Nisibis). The earth was shaking at Antioch, Seleucea and the two Cilicias collapsing them (Chronicle of 724). It was in 571 (Maronite Chronicle). It was in 560-561 at Cilicia, Anazarbus and Antioch (Theophanes). There were tremors at Edessa and Samosata (Micheal the Syrian). It was in 567 October (Chronicle of 1234). - Seiberg (1932): 565, a destructive earthquake in Syria. Aleppo, Baalbak, Damascus, Apamea and Beirut were suffered. It was felt in Mesopotamia.

- Lemmens (1898): An earthquake was in Eastern Mediterranean.

〈041〉 580-581 Antioch: VI-VII; Dafneh: VI. Sources

- Evagrius Scholasticus: 580-581, there was an earthquake in Antioch and Dafneh. In Antioch, public and private buildings were destroyed, some of these were completely. Dafneh was destroyed.

- Nicephorus Callistus: 580-581, as Evagrius Scholasticus.

- Agapius of Menbij: 580-581, a severe earthquake at Antioch, destroying two towers of the city wall.

Parametric catalogues

- Poirier and Taher (1980): 580-581, $I_{0}=$ VIIIIX (MMS), Antioch, the suburb Dafneh was destroyed.

Seismological compilations

- Guidoboni et al. (1994): 580-581, AntiochDafneh $I=I X$, a violent earthquake struck Theopolis (Antioch) and the suburb of Dafneh precisely at noon, causing total destruction of Dafneh and destroyed many public and private buildings in Antioch (Evagrius).

- Sieberg (1932): 579, Antioch and Dafneh were destroyed.

\section{〈042〉 588 Antioch: VI-VII. Aftershocks.}

\section{Sources}

- Evagrius Scholasticus [this author was an eyewitness because the earthquake took place during his marriage]: There was an earthquake with a big sound at Antioch. Many buildings 
fell down. A part of the holy church fell down. The dome was inclined in north direction and fell down by the following shocks. Same happened for most of the district of Ostracina and Brisia. The buildings near the church of the Deipara Virgin fell down, except the Central Portico. The towers in the Kampos fell down while other buildings survived. A large number of persons were killed. No fire.

- John of Nikiu [no indication of the year can be found, except the name of the Emperor Maurice]: An earthquake destroyed Antioch. Many streets at the west and on the island were destroyed. Men were killed.

- Agapius of Menbij: An earthquake at Antioch. The big churches were destroyed as well as most of the city wall, trade square and houses.

- Nicephorus Callistus: Same as mentioned in Evagrius Scholasticus.

\section{Parametric catalogues}

- Plassard and Kogoj (1981): 589 October 21 or $31, I=$ III, an earthquake caused destruction in Antioch with many victims (Perrey).

- Poirier and Taher (1980): 588 October 31, $I_{0}=$ $=$ IX (MMS), Antioch destroyed with 60000 victims.

\section{Seismological compilations}

- Guidoboni et al. (1994): 587-588, Antioch VI$\mathrm{II} \leq I \leq \mathrm{IX}$. In the year of 588 a disaster earthquake in Antioch causing thousands of deaths 60000), razing most buildings to the ground, accompanied by many aftershocks (Evagrius). Antioch suffered a great earthquake, many roads in the east were destroyed, as well as islands and countless victims (John of Nikiu). It was a violent earthquake in 587-588 destroying most of Antioch and killing the inhabitants (Ibn Batriq). It was in the winter of 587 (Michael the Syrian). It was in 588-589 (Chronicle of 1234; Barhebraeus).

- Sieberg (1932): 587 September 30, a destructive earthquake in Antioch. It was said that it caused 60000 victims.

$\langle 043\rangle$ 601-602 Kilikia; Syria. Surface faulting. Sources

- Ibn Batriq: A severe earthquake in the Greek territory. In Syria, many cities were destroyed and many persons were killed.

- Michael the Syrian: Like Ibn Batriq but indicate only «Greek territory».
- Chronicle of 1234: A great earthquake took place in Syria and many cities were destroyed. Seismological compilations

- Guidoboni et al. (1994): 601-602, Cilicia and Syria IX $\leq I \leq \mathrm{XI}$, with surface faulting. Towards the third hour of the day, there was a violent earthquake in the territory of Rum [Cillicia] destroying many cities in Syria and Cillicia, and killing a large number of people (Ibn Batriq). On 2 Nisan [April], in the year of 599, a destructive earthquake affected towns and villages burying their inhabitants, for the earth boiled and split open (Michael the Syrian). There was a great earthquake in Syria in 599, on Monday 19 Canun II [January], and many cities were laid waste (Chronicle of 1234).

〈044〉 634 Aleppo: VII-VIII; Palestine: IV-V. Aftershocks.

Parametric catalogues

- Poirier and Taher (1980): 634, $I_{0}=$ VIII (MMS), Ramparts and fortress were destroyed in Aleppo. Seismological compilations

- Guidoboni et al. (1994): 634, Aleppo VII $\leq I \leq$ $\leq$ VIII, an earthquake destroyed the fortress and walls of Aleppo (Ibn Shaddad).

- Ibn Shaddad: When Abu 'Ubayda conquered the city of Aleppo in the year 15 of the Hegira, the walls and the citadel were restored, for an earthquake before the conquered had destroyed them. - Theophanes: An earthquake in Palestine.

- Michael the Syrian: A severe earthquake. Churches of Resurrection and Golgotha and many places fell down.

- Agapius of Menbij: An earthquake in Palestine. - Erpenius: A large earthquake was in Palestine. Shocks lasted 30 days.

〈046〉 678 Batnan: VI-VII; Orfa: VI-VII; Mesopotamia: VI.

Sources

- Theophanes: A large earthquake took place in Mesopotamia. Church of Edessa was partly destroyed.

- Michael the Syrian: A violent earthquake. Batnan of Sarugi fell down, the church of Edessa was partly destroyed.

- Chronicle of 846: A violent earthquake destroyed Batnan of Sarugi and the ancient church of Edessa, a large number of people was killed. 
- Chronicle of 819: A violent earthquake destroyed many places in Syria. Batnan of Sarugi was demolished, some destruction in the church of Edessa.

- Agapius of Menbij: An earthquake was at Beisan and Qatnan (unknown sites), city of Sarugi was struck, and the city wall and its houses fell down as Edessa and damage in many places.

- Chronicle of 1234: An earthquake destroyed Sarugi and partly the ancient church of Edessa. - Chronicon Pseudo-Dionysus of Tell-Mahre: A big and violent shock. Batnan of Sarugi was destroyed and the ancient church of Edessa. There was a large number of casualties.

Seismological compilations

- Guidoboni et al. (1994): 679 April 3, an earthquake struck Batnan, the city of Edessa and Mesopotamia. A great earthquake struck Batnan of Sarug and the old church of Edessa collapsed and many people died (Chronicle of 846). There was a violent earthquake in 677678 , it struck Mesopotamia and the dome of the church of Edessa collapsed (Theophanes).

- Sieberg (1932): 678, a strong earthquake destroyed many cities in Syria. It was said that 170000 people were killed. Edessa and Batnae in West Mesopotamia were damaged.

$\langle 047\rangle 713$ February 28 Antioch: VI-VII; Aleppo: VI-VII; Kennesreen: VI-VII. Aftershocks. Sources

- Theophanes: A strong earthquake in Syria.

- Agapius of Menbij: A violent earthquake destroyed many buildings at Antioch.

- Chronicle of 819: A violent earthquake in all places of Syria, causing many casualties.

- Chronicle of 846: An earthquake destroyed in all Syria and many casualties.

- Chronicle of 1234: A violent earthquake, where many places were destroyed in the zone of Antioch, Aleppo and Qennesrin, all churches and temple fell down.

- Elias of Nisibis: Earthquakes lasted 40 days. Antioch fell down.

- Al-Isfahani: Earthquakes took place in some part of the world for 40 days. In Antioch, buildings and houses fell down.

- Notitia annorum 712-716 (information of the years 712-716): A shock and violent earthquake. Houses, villages, churches and many large cities fell down killing the inhabitants, some men were burned and other survivors in Antioch and district of Sidqa and Ksyut and coastal entire island, it was remaining until 1027.

- Ibn Al-Athir: In this year (713 A.D., 94 A.H.) there were earthquakes in Al-Sham which lasted for 40 days, causing destruction of the towns, particularly at Antioch.

- Al-Suyuti: In this year (713 A.D., 94 A.H.) March 20, earthquakes lasted for 40 days in the world, causing destruction of buildings (tall buildings). Most of Antioch fell down.

Parametric catalogues

- Plassard and Kogoj (1981): 713 February 28, in Lebanon $I=I V$, an earthquake caused destruction at Antioch, where there was a seismic crisis between December 712 and 715 (Berloty; Michael the Syrian; Perrey).

- Poirier and Taher (1980): 713 March 20, $I_{0}=$ IX (MMS), Antioch was completely destroyed.

- Ben-Menahem (1979): 713 February 28, $M_{l}=7.0$, destruction of Antioch. Felt in Egypt. (Ergin et al.; Plassard and Kogoj; Sieberg).

Seismological compilations

- Guidoboni et al. (1994): 713 February 28March 10, Antioch, Aleppo and Qennesrin VI$\mathrm{II} \leq I \leq \mathrm{X}$ and other earthquake in 717 December, 24 in Mesopotamia and Syria. A violent earthquake struck Syria in 713, 28 February (Theophanes). On 28 February, 713 there was a tremor and severe earthquake causing many villages and towns to collapse on their inhabitants, some houses, villages and cities were swallowed up in the region of Antioch and district of Sidqa and Ksyut, and the whole coast and the islands, this earthquake or tremor lasted from 28 February to 715-716 (Notitia annorum 712 -716). During the year (7 October 712-25 September 713), earthquakes began in the world and lasted for 40 days, causing the collapse of high buildings and houses in Antioch (Al-Asfahani). There were earthquakes in Syria lasting for forty days, and the whole country collapsed, the strongest shocks took place at Antioch (Ibn Al-Athir). There was a tremor in every region of Syria, killing countless people (Syriac Chronicle of 846). Aleppo and Qennesrin were damaged by a violent earthquake on 28 February where many places collapsed in the region of Antioch, Aleppo and Qennesrin (Michael the Syrian). 
- Sieberg (1932): 713 February 28, a strong earthquake occurred in Syria, destroying Antioch. The earthquake was felt in Egypt. Aftershocks continued for one month.

〈048〉 717 December 24 Antioch: VI-VII; Batnan: VI-VII; Orfa: VI-VII. Aftershocks.

Sources

- Theophanes: A violent earthquake in Syria.

- Agapius of Menbij: A violent earthquake took place, where many places were damaged.

- Chronicle of 846: A violent earthquake occurred and sound like a big torus.

- Michael the Syrian: A big earthquake.

- Georgius Cedrenus: An earthquake in Syria.

- Elias of Nisibis: An earthquake was in Meso-

potamia, where many houses fell down. Shocks continued for 3 months.

- Chronicon Pseudo-Dionysus of Tell-Mahre: A big earthquake destroyed many places, temples, churches and the ancient church of Edessa and Batnan of Sarugi. Same happened for important tall constructions which fell down over the citizens [note: the author seems to be merging information from different dates or earthquakes 678].

Parametric catalogues

- Plassard and Kogoj (1981): 717, I=III, an earthquake occurred at Antioch and Syria (AlSuyuti; Anastase; Perrey).

Seismological compilations

- Guidoboni et al. (1994): In 717-718 a strong earthquake in Syria (Theophanes). A great earthquake on 24 December (Syriac Chronicle of 846). In 717-718 a severe and terrible earthquake destroyed many places, including temples, churches and great buildings, in particular Batan and the ancient church of Edessa were destroyed (Pseudo-Dionysius). In the year (14 August 717-2 August 718) an earthquake was in Mesopotamia, where many houses collapsed and the shocks lasted for six months (Elias of Nisibis).

- Sieberg (1932): 717 or 718, an earthquake in Syria.

$\langle 049\rangle 749$ January 18 (It seems to be that there are two earthquakes, the first is in Southern Syria while the second is in the northern part and Mesopotamia that Manbej could be affected). Mount Tabor: VII-IX; Baalbak: VIII; Bosra:
VII; Nawa: VIII; Balqa: VIII; Al-Quds: VII; Beit Qubayeh: VII-VIII; Tabaryya: VII; AlGhouta and Manbej: VII; Darayya: VI; Damascus and Daraa: V-VI; Ariha. Surface faulting and liquefaction in Mesopotamia. Landslide at Mount Tabor.

Sources

- Al-Suyuti: In the year of 130 A.H. (started from 747 September 11) a shock occurred in Damascus causing panic and the Hens Souk fell down. In the year 131 A.H. (started from 748 August 31) a great shock occurred in Damascus, fracturing the roof of the Mosque.

- Al-Mansouri: In the year 132 A.H. (started from 749 August 20) there was an earthquake at Al-Sham.

- Theophanes: 749 January 18, a violent earthquake occurred in Palestine, Jordan and in all of Syria, many tens of thousands of casualties, churches and monasteries fell down especially near Jerusalem. Some cities were completely destroyed and some partly. In Mesopotamia, the land was opened for 2 miles where the eyewitness saw an ancient statue. Landslide for one city completely.

- Michael the Syrian: 749 January 18, an earthquake was in Damascus for some days; one fortress was completely destroyed and 800 casualties in the city. In Ghouta and Daraya, many casualties. Bosra, Nawa, Dar'a, Baalbak were completely swallowed up. In the region of Balqa (Mu'ab), a fortress was taken and thrown 3 miles away. City of Tiberias destroyed. Near the mount of Thabor, a village was moved for 4 miles without damage. A source of water near Ariha was moved 6 miles. In Maboug, the earthquake was during the prayer time.

- Chronicon Pseudo-Dionysus of Tell-Mahre: 749 January 18, in Manbej, and during the time of prayer, the church fell down.

- Chronicle of 1234: 749 January 18, there was an earthquake for some days in Damascus, a fortress at Beit Cubaya was destroyed, 800 casualties, the same in Ghuotah and Daraya, many casualties were heavily damaged, Bosra, Nawa and Baalbak fell down partially, a fortress in Mo'ab was thrown for 3 miles. The city of Tabaria was destroyed and a village near Thabor Mountain was shifted without damage. Mabboug was destroyed. - Elias of Nisibis: 749 January 18, many earth- 
quakes occurred and many places fell down. A village near Tabor Mountain was shifted for 4 miles. The church of Mabboug fell down over the people.

- Agapius of Menbij: 749 January 18, a violent earthquake hit the coast of Palestine, many villages were hit and many casualties in Tiberias more than 100000 casualties

- Georgius Cedrenus: 749 January 18, a big earthquake took place in Palestine, Jordan and all of Syria. There were many thousands of casualties. Monasteries and temples fell down.

- Nicephorus of Costantinopolis: 749 January 18, a violent earthquake hit Syria, the cities were swallowed up and some buildings were shifted for 7 miles. In Mesopotamia, a deep hollow was formed. - Georgius Monachus: 749 January 18, a big earthquake destroyed the cities, some completely and other partially, the tall buildings fell down or shifted. In Mesopotamia, a deep hollow was formed for three miles.

- Al-Dhahabi: A strong earthquake in Syria. It was the strongest in Jerusalem, causing many casualties.

- Ibn Tagri Birdi: A violent earthquake in Syria destroyed Jerusalem.

Parametric catalogues

- Plassard and Kogoj (1981): They considered that there were two events, the first was on 746 January $18(I=\mathrm{V})$ in Palestine with destruction (Anastase; Perrey; Sieberg) and the second was in $748(I=$ VII $)$ at Damascus with destruction (AlSuyuti).

- Ben-Menahem (1979): 746, January 18, wednesday evening after $16 \mathrm{~h}, 32.0 \mathrm{~N}, 35.5 \mathrm{E}$, fault extended northwards over $120 \mathrm{~km}, I_{0}=\mathrm{XI}$, $M_{l}=7.3$, felt in Egypt, Syria, Arabia and Mesopotamia. Great damage in Tiberias (30 synagogues destroyed), Jerusalem, led, Arad and to monasteries north of the Dead Sea. About 600 settlements in Judea, Samaria and Galilee were hit and many casualties reported. Destruction of Hisham palace near Jerico and the city of Gerasa. Tsunami in the Dead Sea and possible flooding of Dead Sea southern basin (Al-Sinawi and Ghalib; Amiran; Avi-Yonaha; Bahat et al.; Michel the Syrian; Neev and Emery; Plassard and Kogoj; Sieberg; Willis).

Seismological compilations

- Guidoboni et al. (1994): 749 January 18, Baal- bak, Beit Qubayeh, Bosrah, Damascus, Daraa, Darayya, Al-Ghouta, Jerico, Jerusalem, Mabbug, Nawa, Tiberias, Mt. Tabor, Palestine, Mesopotamia and Syria (Jerusalem and Mabbug IX $\leq$ $\leq I \leq \mathrm{X}$ ), in the mid 8th century, a powerful earthquake struck Palestine, inflicting serious damage at Jerusalem and Tiberias, and causing a landslide at a village near Mt. Tabor. There are two problems relating date of this event and either it was a single earthquake or a series of tremors, however it dated back to 18 January 749 (Tsafrir and Foerster, 1992). A powerful earthquake dated back to 18 January 747 occurred in Palestine, along the Jordan River and throughout Syria, killing thousands of people and collapsing churches and monasteries, especially in the desert near Jerusalem (Theophanes). There was a strong earthquake in Syria during the year (11 September 747-30 August 748), where the strongest shocks occurred in Jerusalem, causing the death of many conquering troops and others (Al-Dhahabi). There was a strong earthquake in Syria which destroyed Jerusalem, during the year (31 August 748-19 August 749) (Ibn Tagri Birdi). A severe and powerful earthquake in the West, the temple of Mambej collapsed totally in the year 747-748 (Pseudo-Dionysius). During the year (30 August 748-19 August 749) there were many earthquakes and many places were reduced to ruins, a village near Mt. Tabor moved four miles from its original position and in that year a church in Mambej collapsed (Elias of Nisibis). A tremor at Damascus lasted for days, a fortress in Beit Qubayeh collapsed and many people were killed, many myriads of people perished in Al-Ghouta and Dareya, while Bosra, Nawa, Dar'a and Baalbak were completely swallowed up, changing the color of water spring in the city, sea waves destroyed most of the cities and villages along the coast, the fortress of Balqa on the coast was uprooted, Tiberias collapsed, a village near Mt. Tabor was moved four miles with its houses and other buildings without any destruction, a water spring near Jerico changed its original place for six miles, destruction of churches and deaths in Mambej, most the buildings in Constantinople, Nicea and other cities collapsed (Michael the Syrian). Regarding (Tsafrir and Foerster, 1992) chronological analysis, they considered the Babylonian dating instead of the Antiochene sys- 
tem, they dated this event back to 749 January, 18. An earthquake in Mesopotamia and Syria in the year of 749-750, causing various levels of destruction in many cities and large-scale surface faulting in Mesopotamia (Theophanes).

- Ambraseys et al. (1994): 747 January 18, morning, 31.8N-35.7E, $I \leq \mathrm{VI}$. In 747 January 18 , a large earthquake centering the Dead Sea region was felt in Egypt, some damage was caused in Damietta, in Fustat the shock was strongly felt and caused fear but no damage. There is a considerable confusion over the dating of this event, which the Arabic sources put in 130 A.H. began 11 September 747 (Al-Dhahabi; Al-'Ulami; AlSuyuti; Caetani; Sibt Ibn Al-Jawzi; Taher), and January 748 has recently been proposed as the correct date (Ben-Menahem; Gil; Russell; Sieberg), the effects of the earthquake are frequently confused with those of another event that affected parts of Syria two years later (AlKhwarazmi; Tsafrir and Foerster).

- Russell (1985): 748 January In January 18, 747 , a great earthquake occurred in Palestine, around the Jordan, and in all of Syria, to such an extent that many innumerable and countless people perished in its power, and churches and monasteries collapsed (Theophanes). On 18th day of January at the 4th hour in the 6th year, there was a great earthquake in Palestine, and towards the Jordan, and throughout all of Syria. Many thousands of people perished, and churches and monasteries collapsed (Cedrenus). Russell evaluated the date to be from June 746 through May 747. That night there was a great earthquake in the land from the city of Gaza to the furthest extremity of Persia, many houses were ruined in all the cities, and none was saved from them. On the sea, many ships were sunk on that night. Six hundred cities and villages were wrecked with a vast destruction of men and beasts, but Egypt was uninjured, except Damietta. At Misr, there was only great fear without damage (Severus Ibn Al-Muqaff). There was an earthquake at Damascus which lasted for days, a fortress in Beit Qubayeh collapsed and many people were killed, many myriads of people perished in AlGhouta and Darayya, while Bosra, Nawa, Dar'a and Baalbak were completely swallowed up, sea waves destroyed most of the cities and villages along the coast, the fortress of Balqa on the coast was uprooted, Tiberias was destroyed except for a house, a village near Mt. Tabor was moved four miles with its houses and other buildings without any destruction, a water spring near Jericho changed its original place for six miles, destruction of churches and deaths in Mabbug (Michael the Syrian). Russell suggested a date between September 747 and August 748 for this event. There were many earthquakes where many regions gave way. A village near Mt. Tabor was displaced 4 miles along with houses and their possessions, but without damage. The church of the Jacobites in Mabbug collapsed on Sunday and many people perished in it (Elias of Nisibus). Russell also suggested that this event occurred between September 747 and August 748.

Monographs

- Tsafrir and Foerster (1992): A major earthquake occurred in 749 January 18 (according to Margaliot and archaeological evidences found in Bet Sheam), in Palestine and throughout Syria, destroying Jerusalem, Gerasa, Jericho, Pella, Capernaum, Sussita, Bet Sheam and many sites along the Jordan Valley, killing many tens of thousands of people (Cedrenus; Dionysus of Tellmahr; Ibn Tagri Birdi; Ibn Al-Muqaffa; Margaliot; Michael the Syrian; Sibt Ibn Al-Jawzi; Theophanes).

〈050〉 757 March 9 Habura: VII; Mesopotamia; Syria; Palestine.

Sources

- Theophanes: A strong earthquake in Syria and Palestine.

- Chronicon Pseudo-Dionysus of Tell-Mahre: A big and terrible shock in the region of Mesopotamia. Near Harbura, three villages fell down. Seismological compilations

- Guidoboni et al. (1994): 757 March 9, Habura, Palestine, Syria and Mesopotamia $I=I X$. A powerful earthquake struck Syria and Palestine on 9 March 757 (Theophanes). In the year 756 on Tuesday 3 March, there was a great, violent and terrible earthquake in the land of Mesopotamia where three villages near Habura collapsed, many people there were crushed and perished (Pseudo-Dionysius).

- Russell (1985): An earthquake by no means 
mild, affected Palestine and Syria on 9 March 757 (Theophanes).

〈054〉 835 January 5-December 25 Antioch: VI-VII. Aftershocks.

Sources

- Al-Suyuti: In the year 220 A.H. (started from 835 January 5) the earth shook for 40 days and Antioch destroyed.

Seismological compilations

- Guidoboni et al. (1994): 835 January 5-December 25 , Antioch IX $\leq I \leq \mathrm{XI}$, the earth shook for forty days, and Antioch was destroyed (AlSuyuti).

$\langle 055\rangle 846$ August 28-847 August 16 Antioch: > VIII; Damascus: VII; Homs: VII; Antioch, Al-Jazira: VI; Al-Mousel: VI. Aftershocks. Sources

- Al-Suyuti: During the year 232 A.H. (started from 846 August 28) many earthquakes occurred in the world in particular, in Morocco and AlSham. The walls of Damascus and Homs were collapsed. It was worst at Antioch. It caused destruction in Al-Jazira and Al-Mousel and lasted for many days.

Seismological compilations

- Sieberg (1932): 846, numerous places in Lebanon exposed to many sequences of shocks, to such an extent that landslides occurred.

〈056〉 847 November 24 Damascus: VII-VIII; Al-Ghouta: VII-VIII; Al-Mazzeh: VII; Beit Lahya: VII; Darayya: VII; Antioch: VI; AlMousel: V.

Sources

- Al-Dhahabi: In 253 A.H. Rabi' II, it was a dreadful earthquake in Damascus which lasted for three hours, causing walls to fall down and people die under debris. It extended to Antioch killing 20000 as it was said, then to Al-Mousel where 50000 people were killed under debris as it was said.

- Al-Suyuti: In 253 A.H. 11 (847 A.D. November 25) there was a dreadful earthquake in Damascus where houses fell down and people died under debris. This earthquake extended to Antioch causing destruction, to Al-Jazira causing damage, and to Al-Mousel killing 50000 people as it was said. In his book Al-Zalazel (the earthquakes), Al-Hafez Ibn Asaker mentioned that there was an earthquake in Damascus on Thursday 11 Rab' 253, destroying a quarter of the Ommyad Mosque the great, the minaret fell down and bridges and houses collapsed, this earthquake reached Al-Ghouta where Darayya, Al-Mazzeh, Bait Lahya and others were destroyed.

New original sources

- Ibn Al-Imad: an earthquake caused heavy shaking in Damascus since morning for $3 \mathrm{~h}$, destroying houses and displacing huge stones and breaking many windows of Souks and killing many people under debris. Many terraces of Ommyad Mosque the Great fell down, a quarter of its minaret fell down. A village in Al-Ghoutah was overturned on its inhabitants unless one person survived. It was strong at Antioch and Al-Mousel where more than 2000 houses collapsed over their residents and 20000 victims.

Parametric catalogues

- Plassard and Kogoj (1981) 847 November 24, $I=\mathrm{V}$ in Lebanon, this earthquake caused destruction in Damascus and damage in Homs (Al-Suyuti).

- Ben-Menahem (1979): 847, $M_{l}=6.2$, destruction in Lebanon (Plassard and Kogoj; Sieberg; Willis).

Seismological compilations

- Guidoboni et al. (1994): 847 November 24, Antioch, Bayt Lahya, Damascus IX $\leq I \leq X I$, Darayya, Al-Ghoutah, Al-Mousel and Al-Mazzah. A dreadful earthquake occurred at Damascus, causing the walls to collapse and people to die in the ruins, the earthquake reached Antioch and 20000 people died there and it reached Mawsel where 50000 people died in the ruins (Al-Dhahabi). The earthquake took place on 24 November 847, it was strong in Damascus, destroying a part of the Ommiad Great Mosque, the minaret fell down and bridges and houses collapsed, it reached Al-Ghouta, Darayya, AlMazzeh, Bayt Lahya and others were destroyed (Al-Suyuti).

$\langle 057\rangle$ 853 June 12-854 June 1 Tabariya: VIIIIX. Landslide.

Sources

- Ibn Al-Imad: The earth shook Tiberias at 
night, then a huge part $(80 \times 50$ Zeraa $)$ of its mountain split open, and many people were killed.

Parametric catalogues

- Plassard and Kogoj (1981): 853-854, I= III, a strong earthquake occurred in Tiberias (AlSuyuti).

Seismological compilations

- Guidoboni et al. (1994): 853 June 12-854 June 1 ,Tiberias $\mathrm{VIII} \leq I \leq \mathrm{X}$, landslide, The earth shook at Tiberias, a huge part of the mountain split open, and so ... many people died (Ibn Al-Imad Al-Hanbali).

$\langle 058\rangle 859$ December 30-860 January 29 (It could be two earthquakes, the first one is between Antioch and Lattakia while the second is on the Euphrates). Antioch: VIII; Lattakia and Jableh: VIII; Homs: VII; Palmyra: VII; Tarsus: VI; Balis: VI; Damascus: VI; Adana: VI; AlQuds: V-VI; Ar-Raqqa: V; Ras Al-Ein: V; Harran: V; Orfa: V; Egypt: IV (fig. 6). Landslide. Sources

- Al-Mansouri: In the year 244 A.H. [858 April
19-859 April 7], a great earthquake occurred in Al-Sham, damaging Antioch, Homs and Palmyra.

- Al-Tabari: In Shawwal 245 A.H. (859 December 30-860 January 29), there was an earthquake at Antioch, collapsing 1500 houses, killing many people, half of the city wall and 90 towers fell down and people ran out to desert. A part of Jabal Al-Akraa was split and sank into the sea generating high waves, disappearing river there. It was said that inhabitants of Tnis (Egypt) heard a high noise which led to the killing of a large number of victims. In this year the earthquake shook Balis, Raqqa, Harran, Ras Al-Ain, Homs, Damascus, Al-Ruha, Tarsus, Adana and the Syrian coasts. In Lattakia the shock caused destruction of all houses and some survivals there escaped. Same happened to Jableh.

- Al-Suyuti: [...] The earthquake passed the Euphrates after destroying Balis and its around [...]. - Saadeh (1984): in the year 859-860, a violent earthquake occurred at Lattakia, causing destruction of most buildings with a large number of victims.

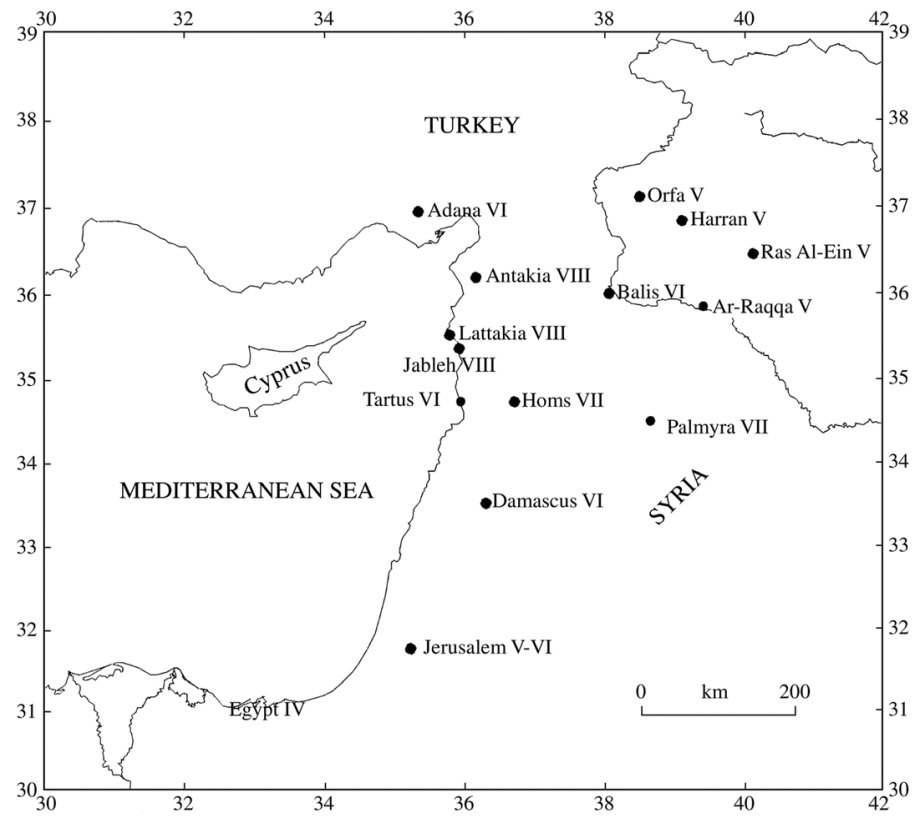

Fig. 6. Map of intensity distribution for the December 859-January 860 A.D. earthquake. 
Parametric catalogues

- Plassard and Kogoj (1981): 859 April 18, in Lebanon $I=\mathrm{VI}$, this earthquake caused destruction in Antioch and damage in Damascus and Homs (Al-Suyuti, Erpenius). Poirier and Taher (1980): 859 December, $I_{0}=\mathrm{X}$-XI (MMS), in Antioch 1500 houses were destroyed, 90 towers fell from the ramparts. Casios Montain (Jabal AlAqra'), $30 \mathrm{~km} \mathrm{SW}$ of Antioch, fell into the sea. A river disappeared into the ground. Cities of Urfa, Adana, Tarsus, Misis, Homs and Damascus were destroyed.

- Ben-Menahem (1979): 859 April 8, 36.2N, $36.1 \mathrm{E}, I_{0}=\mathrm{XII}, M_{l}=8.0$, near Samandag, an inhabited mountain fell into the sea. Total destruction of Antioch. Felt in Mecca, Egypt, Turkey, Armenia, Mesopotamia. Damage in Jerusalem (Al-Sinawi and Ghalib; Amiran; Ergin et al.; Plassard and Kogoj; Sieberg).

\section{Seismological compilations}

- Guidoboni et al. (1994): 859 December 30860 January 29] Adhana, Antioch, Balis, Damascus, Jableh, Harran, Homs, Laodicea IX $\leq I \leq \mathrm{X}$, Al-Massisa, Edessa, Raqqa, Ra's al-'Ayn, Tarsus, Mt. Casius and Syria, landslide, in the year (30 December 859-29 January 860) there was an earthquake at Antioch, killing a large number of people and causing the collapse of 1500 houses and about 90 towers in the walls of the city, Mt. Casius (Jabal Al-Aqra'a) split open and rocks fell into the sea, which was stormy that day, people in Tinnis in Egypt were killed, there was another earthquake in the cities of Balis, Raqqa, Harran, Ra's Al-'Ayn, Hims, Damascus, Al-Ruha, Tarsus, Al-Massisa, Adhanah and along the Syrian coast, the earthquake reached Laodecea, where no home remained standing and only a small number of people escaped (Al-Tabari). Syria was struck by earthquakes which destroyed Laodicea and Jableh and many people were killed (Ya'qubi).

- Ambraseys et al. (1994): 860 January, 37.0N$38.0 \mathrm{E}, I \leq \mathrm{VI}$. In one day of January 860 , a large earthquake in Eastern Anatolia and North Syria, particularly destructive in Antioch, Jableh and Lattakia, was felt in Egypt (Al-Suyuti; AlTabari; Ibn Al-Athir; Taher). This earthquake could be dated in other catalogues on 859 and often under 8 April (Al-Sinawi and Ghaleb; Ben-Menahem; Kallner-Amiran; Poirier and Taher; Sieberg).
- Sieberg (1932): 859 April, a strong earthquake in Northern Syria. It was felt in Asia Minor, Armenia, Mesopotamia, Palestine and Egypt. It killed a large number of people. In Antioch, 1500 houses and 90 towers of the city rampart collapsed. Lattakia and Jableh lost most of their inhabitants. A part of Casius mountain fell into the sea. Damascus, Tarsus, Edessa, Baghdad, Homs, Balis, Adana Harran, Marsin and ...? affected. Minor damage in the mosque of Al-Aqsa in Al-Quds. Shocks lasted for 3 months.

$\langle 066\rangle 1002$ November 10-1003 October 29 Western Syria: $\geq$ VIII.

Sources

- Al-Suyuti: In the year 393 A.H. (1002 November 10-1003 October 29) an earthquake occurred in Al-Sham, cities and towns along the frontiers, causing citadels and fortresses to fall down, and people to die under the debris.

Parametric catalogues

- Poirier and Taher (1980): 1002, $I_{0}=$ VIII-IX (MMS), Syria, border zone much destruction.

\section{$\langle 067\rangle$ 1029 January 20-1030 January 8 Dam-} ascus: VII.

Sources

- Al-Dawadari: in the year 420 A.H. (1029 January 20-1030 January 8) a heavy earthquake occurred in Damascus, collapsing its half and killing many people under the debris.

Parametric catalogues

- Plassard and Kogoj (1981): 1029 January 29, $I=\mathrm{VII}$, this earthquake caused the destruction of half of Damascus (Perrey; Sieberg).

Seismological compilations

- Sieberg (1932): 1029 January 20, a strong earthquake in Syria destroying half of Damascus.

(068) 1042 August 21-1043 August 9 Palmyra: > VII; Baalbak: V; Tabriz: III; Egypt: III. Sources

- Al-Suyuti: in the year 434 A.H. (1042 August 21-1043 August 8) an earthquake occurred in Palmyra and Baalbak. Most people in Palmyra were killed under the debris.

Parametric catalogues

- Ben-Menahem (1979): 1042 August 21, $35.1 \mathrm{~N}, 38.9 \mathrm{E}$, near Palmyra, $M_{l}=7.2$, destruc- 


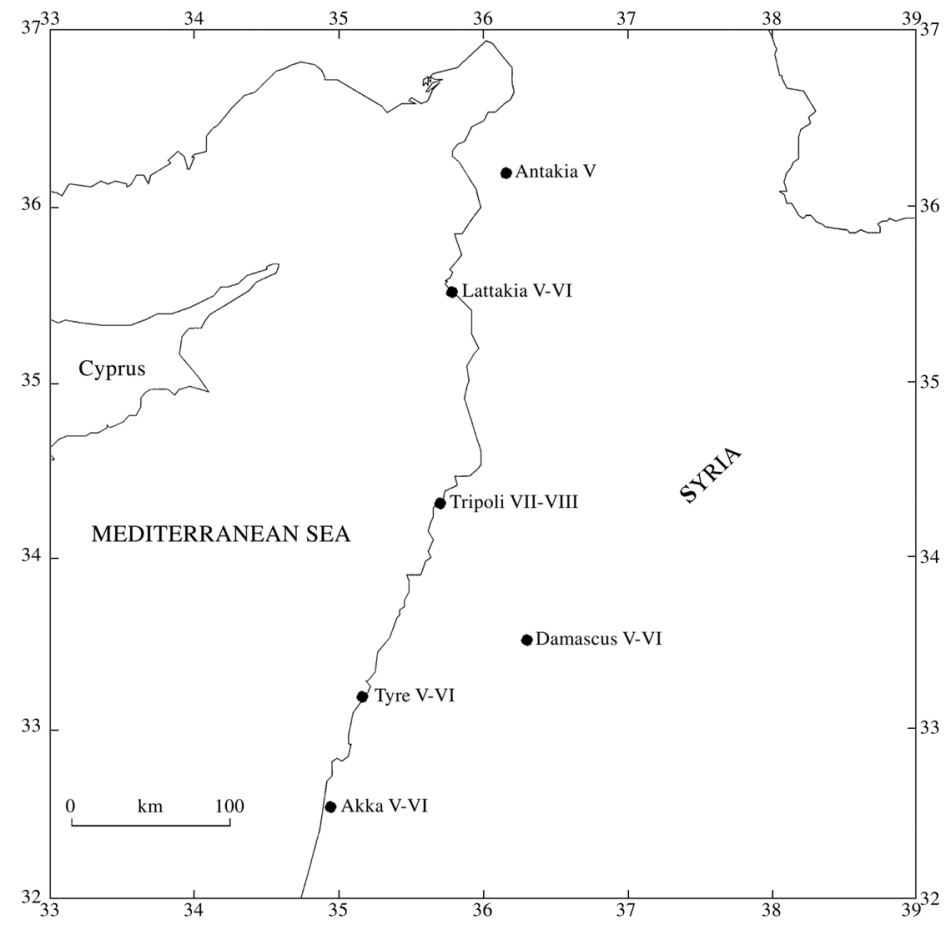

Fig. 7. Map of intensity distribution for July-August, 1063 earthquake.

tion of Palmyra. It was strong in Baalbak. It was felt in Tabriz and Egypt.

Seismological compilations

- Sieberg (1932): 1042 August 21, a strong widespread earthquake occurred to such an extent that it was felt in Tabriz and Egypt. The center of this earthquake seems to be at Palmyra, where it killed most of its inhabitants. It was felt strongly in Baalbak. Victims were evaluated to be 50000 .

〈070) 1063 July 30-August 27 Tripoli: VIIVIII; Lattakia: V-VI; Acre: V-VI; Sur: V-VI; Antioch: V (fig. 7).

Sources

- Al-Suyuti: In 455 A.H. Sha'ban (1063 July 30August 27) there was a great earthquake at Waset, Antioch, Lattakia, Tyr, Akka, Al-Rum and AlSham, falling down a part of Tripoli wall.

- Abu Al-Fida: In this year (455 A.H.) (1063 January 4-1063 December 25), there was a great earthquake in Al-Sham, causing destruction of many cities. The wall of Tripoli collapsed.

- Ibn Kathir: In that year [455 A.H.] in Sha'ban [1063 July 30-August 27], there was a great earthquake in Al-Sham land, where it caused destruction of many towns. Wall of Tripoli was destroyed.

Parametric catalogues

- Plassard and Kogoj (1981): 1063 May, in Lebanon $I=\mathrm{IX}$, this earthquake caused destruction in Tripoli and Akkar region (Al-Suyuti; Perrey).

- Poirier and Taher (1980): 1063 July, $I_{0}=$ VIII (MMS), Antioch, Lattakia, Tripoli and Acre.

- Ben-Menahem (1979): 1063 August, $M_{l}=7.1$, damage in Antioch, Tripoli, Lattakia, Sur and Acre (Amiran; Ergin et al.; Willis).

Seismological compilations

- Sieberg (1932): 1063 or 1083, a strong earthquake occurred in the Syrian coast. Walls of 
Tripoli collapsed. Antioch and Damascus suffered.

\section{$\langle 072\rangle 1091$ September 26 or October 6 Anti-} och: VI-VII.

Parametric catalogues

- Plassard and Kogoj (1981): 1091, I= III (in Lebanon), an earthquake caused destruction at Antioch where 80 towers collapsed (Abu Al-Fida; Al-Suyuti; Berloty).

- Poirier and Taher (1980): 1091 September 17, $I_{0}=$ IX (MMS), in Antioch, 70 towers fell from the ramparts.

Seismological compilations

- Sieberg (1932): 1092, an earthquake was in Syria from Antioch to Damascus. Many buildings were destroyed.

- Ibn Al-Athir: In that year [484 A.H.] in
Sha'ban 9 (1091 September 26) many earthquakes happened in Bilad Al-Sham and other countries, where people left their houses. In Antioch, it caused destruction of many houses with many victims under the debris, and 90 towers of its wall collapsed.

- Al-Dawadari: In 494 Sha'aban 19 (1091 October 6), an earthquake occurred in Antioch, causing the collapse of 70 towers of its wall.

$\langle 075\rangle 1114$ November (Two earthquakes could have happened; one at Maraash and other at Orfa). Maskaneh: VIII; Maraash: VII-VIII; Samsat: VII-VIII; Orfa: VII-VIII; Harran: VII, Aleppo: V; Antioch: IV (fig. 8). Landslide. Sources

- Ibn Al-Jawzi: In the year 508 A.H., the night of 18 Jamada II Sunday (1114 November 19), an

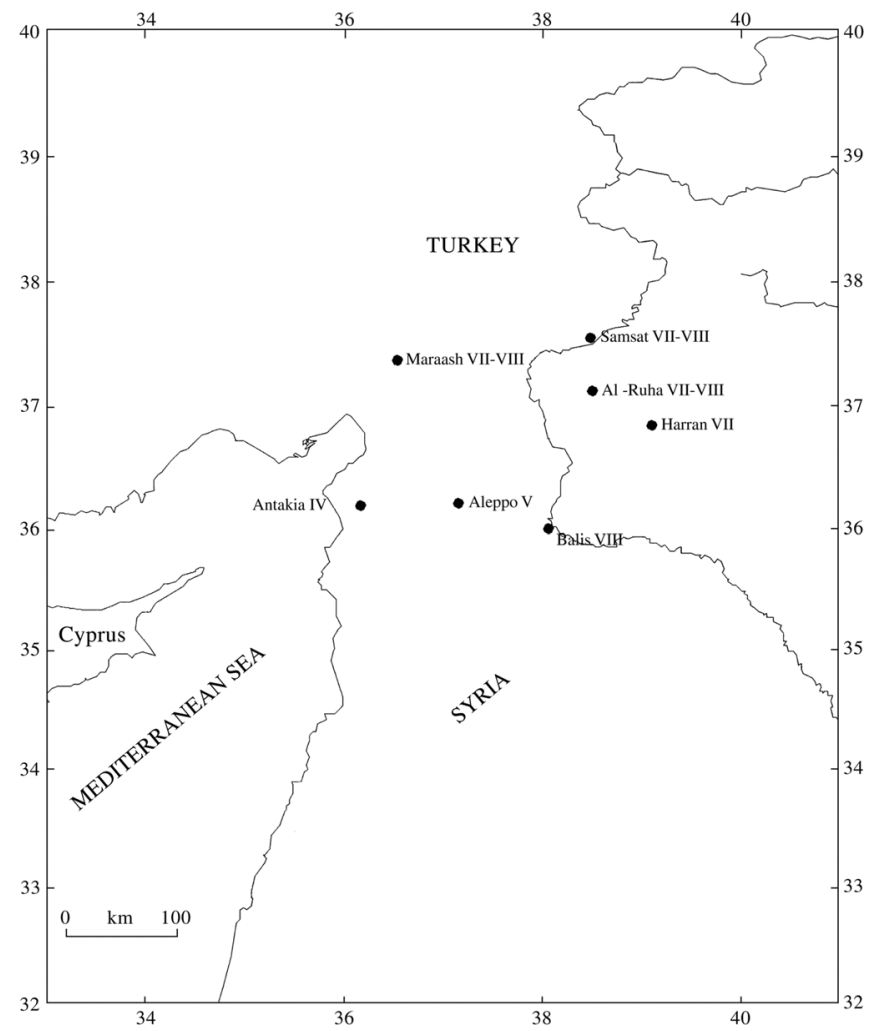

Fig. 8. Map of intensity distribution for November 1114 earthquake. 
earthquake occurred, causing collapse of 13 towers of Al-Ruha Wall, a part of Harran Wall fell down and many houses collapsed on their inhabitants, Samasat was swallowed up, 100 houses and half of the citadel collapsed at Balis.

- Ibn Al-Athir: In this year (508 A.H.) in Jamada II (November 2-30), there was a strong earthquake in Al-Jazira area, Al-Sham and others, causing a wide destruction at Al-Ruha, Harran, Samsat, Balis and others, and many people killed under debris.

- Al-Dawadari: In this year (508 A.H.), there was an earthquake at Aleppo. Samsat and Marash were swallowed up and many people killed.

- Ibn Kathir: In this year (508 A.H.) (1114 January 7-1115 May 26), there was a great earthquake in Al-Jazira, causing destruction of 13 towers and many houses in Al-Ruha and some houses in Khurasan (?) and many houses in many countries where many of its inhabitants were killed about 100000 victims, and half of Harran castle was collapsed, Samsat was swallowed up and many people were killed under debris.

Parametric catalogues

- Plassard and Kogoj (1981): 1114 August 10 and November 13, in Lebanon $I=I I$, there were two earthquakes, causing destruction in Cilicia with tsunami and damage in Antioch (Al-Suyuti; Sempad).

- Ben-Menahem (1979): 1114 August 10, $36.5 \mathrm{~N}, 36.0 \mathrm{E}, M_{l}=7.0$, destruction of Antioch. It was accompanied by a tsunami. It was strongly felt in Palestine. Jerusalem $\left(M_{M}=\mathrm{IV}\right)$ (Amiran; Plassard and Kogoj; Sieberg).

- Ergin et al. (1967): Antioch was felt by the first event. The epicenter of the second one was between Urfa and Harran, the walls of Edessa city were ruined. Samsat, Marash, Antioch and Harran were felt.

- Ben-Menahem (1979): 1115 December 25, 37.0N, 38.9E, Urfa-Harran, Taurus mountains, $M_{l}=7.5$, Jerusalem $\left(M_{M}=\mathrm{V}\right)$. It was strong in Syria. Walls of Edessa destroyed (Amiran; Ergin et al.; Sieberg; Willis).

Seismological compilations

- Sieberg (1932): In 1114 August 10, a vast destructive earthquake started from southwest of Asia Minor through Cillicia and Cyprus to Egypt. There was large destruction in Antioch and minor damage in Aleppo. In 1114 Novem- ber 13, repeating what happened in August in the same regions with the same damage.

〈078〉 1137 October 19-November 16 Syria: VII; Al-Jazira: VII; Al-Mousel: VII; Iraq: VII. Sources

- Ibn Al-Athir: In this year [532 A.H.] in Safar [1137 October 19-November 16], there was a great earthquake in Al-Sham, Al-Jazira, Diyar Bakr, Al-Mousel, Iraq and other countries, causing a lot of destruction in these regions and many people were killed under debris.

- Abu Al-Fida: In this year [532 A.H.] [1137 September 19-1138 September 08], there was a great earthquake in Al-Sham, Iraq and other countries, causing a lot of destruction and many people killed under debris.

Parametric catalogues

- Ben-Menahem (1979): 1137 September 13, NE Aleppo, $M l=7.2$, felt in Mesopotamia and Egypt (Al-Sinawi and Ghaleb; Sieberg; Willis). Seismological compilations

- Sieberg (1932): 1137 September 13, a destructive earthquake in Syria caused a large number of people to kill. It was felt in Mesopotamia and Aleppo. Aftershocks lasted for the next year.

- Ambraseys et al. (1994): 1138 October 15, afternoon, $36.5 \mathrm{~N}-37.0 \mathrm{E}, I \leq \mathrm{VI}$. Earthquake. Shocks were felt in Egypt, originating from the series of earthquakes that devastated Northern Syria.

$\langle 079\rangle 1138$ October 11-26 Al-Sham: VI-VII; AlJazira: VI-VII; Aleppo: VI-VII. Aftershocks. Sources

- Ibn Al-Athir: In this year [533 A.H.] in Safar [1138 October 11-26] there were many great earthquakes in Al-Sham, Al-Jazira and other countries, where the strongest were in Al-Sham lasting for many nights with many aftershocks, causing destruction of many towns such as Aleppo where people ran out leaving their houses to the desert. The earthquakes extended from Safar 4 to 19 in Al-Sham.

- Abu Al-Fida: Same description of Ibn Al-Athir. Parametric catalogues

- Poirier and Taher (1980): 1139 November, $I_{0}=\mathrm{X}-\mathrm{XI}$ (MMS), Aleppo was destroyed and the inhabitants evacuated.

Seismological compilations

- Plassard and Kogoj (1981): 1138 October, in 
Lebanon $I=\mathrm{IV}$, there was an earthquake causing destruction in Aleppo (Al-Suyuti; Berloty; Ibn Al-Athir).

- Sieberg (1932): 1138 September 8, repeating of what happened in the same month of the last year, but it was stronger causing a large number of people to die in Aleppo and Ambar.

\section{〈082 1152 September 27 Bosra: VII; Hau- ran: VII; Syria: VII.}

Sources

- Abu Shama: It was said that on 546 A.H. Jamada II 13 at night [1152 September 27], there was an earthquake, producing 3 shocks in Bosra and Horan regions, causing destruction of many house walls in Bosra and others. On Shawal 2 morning [1152 November 14] there was an earthquake, shaking the earth for 3 times and moving houses and walls.

\section{Parametric catalogues}

- Plassard and Kogoj (1981): 1152 March 22, $I=I V$, it was an earthquake that caused a destruction in Afamea (Sieberg).

- Ben-Menahem (1979): 1151, 32.6N, 36.7E, Jabal Al-Arab (Hauran), $I_{0}=\mathrm{IX}, M_{l}=6.2$, destructive at Bousra and the Hauran. Felt in Palestine (Amiran; Plassard and Kogoj; Sieberg; Willis). Seismological compilations

- Sieberg (1932): 1151, a destructive earthquake in the volcanic area in Al-Nuqra and Horan [Syria], where only Bosra was widely damaged. It was said that large areas of Syria were affected. In 1152 March 22, a destructive earthquake was in Syria, especially in Apamea and Qalaat Al-Madiq.

$\langle 083\rangle 1156$ September-1159 May Western Syria including Damascus. Foreshocks, aftershocks, surface faulting.

New original sources

Depending on quality of the available historical sources, we consider that Ibn Al-Qalansi is the best eye-witness of this seismic crisis in the region during that period, and we summarize his text chronically with intensity evaluation of each described locality.

- Ibn Al-Qalansi: 1156 September 28 (551 Sha'aban 9), 3-4 strong shocks hit Damascus: III-IV. 1156 October 9 (551 Sha'aban 22), 6 shocks were felt in Damascus: II-III. 1156 October 12 (551 Sha'aban 25), 2 shocks hit Dam- ascus: III-IV; Aleppo: V-VI; Hama: V-VI; Afamia: VI. 1156 October 17 (551 Sha'aban 29), 2 shocks was felt in Damascus: III. 1156 October 22 (551 Ramadan 5), there were 3 shocks in Damascus: IV. 1156 October 23 (551 Ramadan 6), 5 shocks were in Damascus: IV-V. 1156 October 31 (551 Ramadan 15), 2 shocks in Damascus. 1156 November 1 (551 Ramadan 16), 2 shocks in Damascus: III. 1156 November 4 (551 Ramadan 18), a strong shock was felt in Damascus: III-IV. 1156 November 8 (551 Ramadan 23), there was a strong shock in Damascus: III-IV. 1156 November 18 (551 Shawwal 2), there was a strong shock in Damascus: IV. 1156 November 22 (551 Shawwal 6), at noon, a shock was in Damascus: III. 1156 December 2 (551 Shawwal 16), there was a strong shock in Damascus: III. 1156 December 3 (551 Shawwal 17), 4 shocks in Damascus: IV. 1156 December 8 (551 Shawwal 23), many shocks in Damascus: IV-V. Aleppo: V-VI, Shaizar: VII-VIII; Kafar Tab: VIVII; Hama: VI-VII. 1157 April 2 to 4 (552 Safar 19, 20 and 21), a shock was felt in Damascus: IV; Shaizar: VI; Hama: VI; Aleppo: V; Kafar Tab: VI. 1157 July 5 (552 Jumada I 25), 4 strong shocks in Damascus: III-IV. 1157 July 13 (552 Jumada II 4), a great earthquake followed by anther one less stronger was in Damascus: IV-V. In Aleppo, it was a frighten earthquake: IV-V. In Homs, it was frighten earthquake with destruction: V-VI. In Hama and Kafar Tab, there was destruction: VVII. Same was in Afamia: V-VII. In Tayma, there was damage: V. 1157 August 12 (552 Rajab 4), a great earthquake was in Damascus, causing partial destruction: V-VI; Hama: VIII-IX; Shaizar: VIII-IX; Kafar Tab: VIII-IX.; Afamia: VIII-IX; Arqa: VIII-IX; Aleppo: VII-VIII; Homs: VII-VIII; Lattakia: VII-VIII; Tripoli: VII-VIII; Antioch: VII-VIII; Shmemis: VII-VIII; Qalaat Al-Hosn: VII-VIII; Maarret Annooman: VI-VII; Tel Harran:? (fig. 9). 1157 August 16, 17 and 18 (552 Rajab 8, 552 Rajab 9, 552 Rajab 10), there were 4 main earthquakes and series of shocks in Damascus: III-IV. 1157 September 6 (552 Rajab 29), a frightening earthquake was in Damascus: IV-V. 1157 October 30 (552 Ramadan 24), many shocks were in Damascus: IV-V. In Aleppo, there was light damage to the houses: VI. In Hama, there were a destruction with sound: VII-VIII. 1157 November 14 (552 Shawwal 10), a strong 


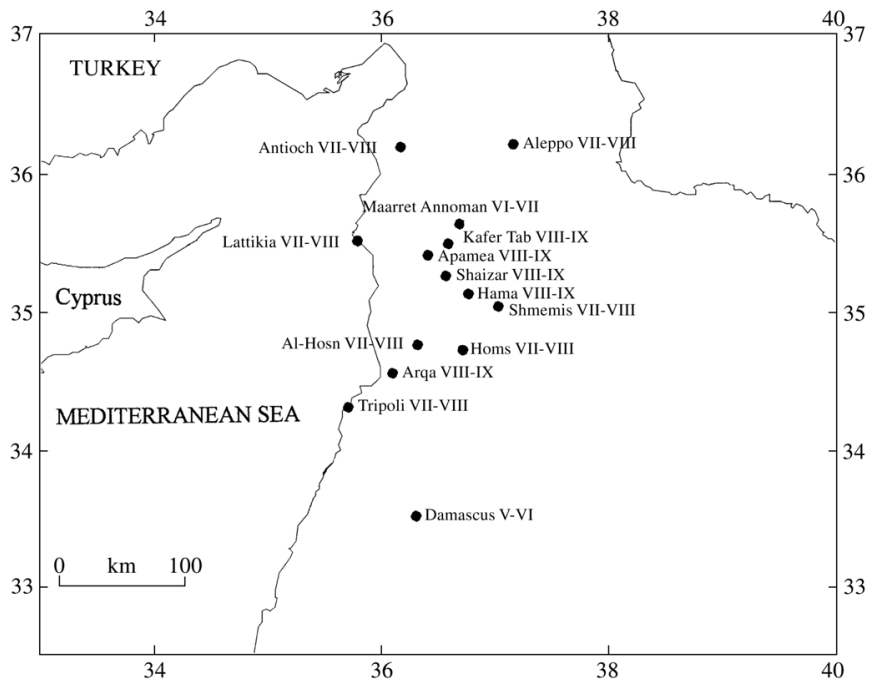

Fig. 9. Map of intensity distribution for August 12, 1157 earthquake.

earthquake caused a panic in Damascus: III-IV. 1157 December 13 and 14 (552 Dhul Qi'ada 10), there were 2 shocks in Damascus: III-IV. 1157 December 26 (552 Dhul Qi'ada 23), there was a shock in Damascus: IV. 1157 December 28 (552 Dhul Qi'ada 25), there were 6 shocks causing a panic in Damascus: IV-V. 1158 January 1 (552 Dhul Qi'ada 30), there were many shocks in Damascus: III-IV. 1158 April 16 (553 Rabi'a I 15), Aleppo was shaken: IV. 1158 April 25 (553 Rabi'a I 25), there was a shock in Damascus: III. 1158 August 20 (553 Rajab 23), there was a shock in Damascus: III. 1158 August 21 (553 Rajab 24), there was a shock in Damascus: III. 1159 January 23 (554 Muharram 1), there were 3 shocks in Damascus: III. 1159 April 12 (554 Rabi'a I 22), there was a shock in Damascus: IV-V. 1159 May 30 (554 Jumada I 10), there was a shock in Damascus: IV.

- Ibn Al-Athir: In this year [552 A.H.] in Rajab [1157 August 9-September 7], there were many strong earthquakes, causing destruction of many towns and killing a countless number of people. Hama, Shaizar, Kafar Tab, Maarret, Afamia, Homs, Crac Des Chevaliers, Arqa, Lattakia, Tripoli and Antioch were totally destroyed. The remaing towns in Bilad Al-Sham were partially de- stroyed. Ramparts of the towns and fortresses collapsed.

- Abu Al-Fida: In this year (552 A.H.), Rajab, there were strong earthquakes, causing destruction of Hama, Shaizar, Homs, Hosn Al-Akrad, Tripoli, Antioch and other places, to the extent that fortresses and walls fell down. Large number of people were killed under debris.

- Bar Hebraeus: And in this year, which is the year 552 of the Arabs (1157 A.D.), severe earthquakes took place in Syria destroying many towns. In Hamth [Hama], its fortress and all its large houses fell down. Old men, women, children, and tens of thousands of its inhabitants perished. The fortress of Shaizar fell down, every part of it, and only women and eunuch escaped. The people of Emessa went forth hastily and were delivered, but their monasteries and fortress perished. In the same manner, the people of Aleppo fled from the city, and stayed outside for a few days. Their houses in the city were thrown down with perishing of five hundred souls. Similar was in Kafar Tab and Afamia where no one escaped. Cities of Franks, Hosn Al-Akrad and Arqa fell completely. In Laodicea the great church only remained, and all those who were inside were delivered. The ground inside the church was rent 
asunder, and a chasm which was full of clay appeared, and in the middle of the clay a molten image was standing upright. Similarly, most of Antioch and Tripoli were destroyed.

- Chronicle of 1234: And the year of 1462 arrived. In that year, there was a large earthquake and Sayzar [Shaizar] fell down. Forty thousand persons were killed. The governor and his children were among those who were killed. The citadel that was built on a mountain fell down. A great number of persons were killed in Hama, Salamiya and in many nearby villages.

- Michael the Syrian: And in this year, there were severe earthquakes in Syria and many places were destroyed. In Hamath, the fortress, the town and all large houses fell down upon the citizens. Old men, women, children and a myriad of persons were killed. The fortress of Saizar fell entirely, except a woman and a eunuch. And the people of Emessa were taken by the fear: they fled the town and were delivered. Their houses and the fortress were destroyed. And in same manner, the people in Aleppo fled from the city, and sat down outside it for a few days and were delivered, and their houses were thrown down, and only five hundred persons perished in it. Same was at Kaphar Tab, and Afamia, no one escaped, and many other places as far as Rahabot. Cities of the Franks, Hosn Al-Akrad and Arqa fell down completely. In Laodicea, the great church only remained, and all those who were in the church were delivered. In some cities, the earth was opened. In this city, the earth was opened and lying to watch a chasm full of mud, and in the center of the mud a statue, staying upright, was fusing. Similarly, the greater part of Antioch and Tripoli was destroyed.

- Saadeh (1984): In 1157, there was a very large earthquake in Northern Syria, causing heavy damages in Lattakia and other cities.

Parametric catalogues and previous studies

- Ambraseys and Barazangi (1989): 15 August $1157,35.1 \mathrm{~N}, 36.3 \mathrm{E} M_{s}>7.0$ Hama.

- Ben-Menahem (1979): 1157, July 15, $M_{l}=6.1$, destruction of Baalbak (Amiran; Plassard and Kogoj; Sieberg).

- Plassard and Kogoj (1981): 1157 June 4, 14 and August $12, I=$ VIII, there were earthquakes causing destruction in Tripoli, Krak, Homs, Hama and Sheizar. Hama and Sheizar citadel were the most affected sites. New earthquakes till 1158 (Al-Suyuti; Berloty; Ibn Al-Jawzi).

〈084〉 1170 June 29 Damascus: VII-VIII; Homs: VII-VIII; Hama: VII-VIII; Al-Sham: VII-VIII; Lattakia: VII-VIII; Baalbak: VIIVIII; Shaizar: VII-VIII; Barin: VII; Aleppo: VII-VIII; Iraq: V; Al-Jazira: V; Al-Mousel: V (fig. 10). Aftershocks, tsunami. Sources

- Abu Al-Fida: In this year [565 A.H.] [1169 September 25-1170 September 14], there was a great earthquake, destroying Al-Sham.

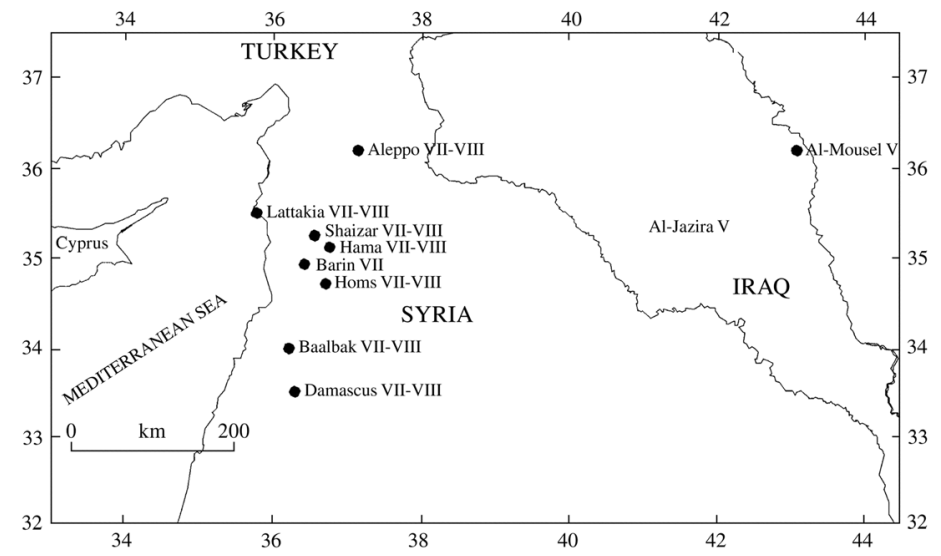

Fig. 10. Map of intensity distribution for June 29, 1170 earthquake. 
- Ibn Al-Athir: Also in this year [565 A.H.] 12 Shawwal [1170 June 29], there were successive great terrible earthquakes which had never been seen before. Al-Sham, Al-Jazira, Al-Mousel, Iraq and other countries were affected. They were strongest in Al-Sham, where most of Damascus, Baalbak, Homs, Hama, Shaizar, Barin, Aleppo and others were destroyed, with their ramparts and fortresses, houses collapsed over their residents, killing countless numbers of people. Sultan Nur ed-Din visited these later towns and ordered to rebuild their ramparts and fortresses, while he found Aleppo had not been destroyed as these towns previously. Bilad Al-Firnj [in that time during the Crusader wars the Syrian coastal area was occupied by the Crusaders and called in Arabic Bilad Al-Firanj] was affected.

- Saadeh (1984) during the year of 1170 , there was a very large earthquake that occurred in Northern Syria, causing heavy damage in Lattakia and other cities.

Parametric catalogues

- Ambraseys and Barazangi (1989): 1170 June $29,35.9 \mathrm{~N}-36.4 \mathrm{E}, M_{s}>7.0$, tsunami.

- Plassard and Kogoj (1981): 1170 June 29, in Lebanon $I=I X$, there was an earthquake, causing destruction in Tripoli and Aleppo (Al-Suyuti; Berloty; Guillaume de Tyre; Perrey).

- Poirier and Taher (1980): 1170 June 30, $I_{0}=$ IX$\mathrm{X}$ (MMS), Aleppo was totally destroyed with 80000 victims. Damage in Orontes Valley. In Antioch, St. Peters cathedral collapsed over the patriarch.

- Ben-Menahem (1979): 1170 June 29, 34.6N, $36.2 \mathrm{E}, I_{0}=\mathrm{XI}-\mathrm{XII}, M_{l}=7.9$, damage and casualties in Palestine. It was felt throughout Mesopotamia, Cyprus and Upper Egypt. Tripoli ruined. Destruction at Damascus, Sur, Sidon and Baalbak (most columns fell down). Damage to the walls of Sur. Jerusalem $\left(M_{M}=\mathrm{V}-\mathrm{VI}\right)$. The obelisk at Caesaria may have been thrown down (Amiran; Humphrey; Plassard and Kogoj; Sieberg; Willis).

Seismological compilations

- Ambraseys et al. (1994): 1170 June 29, $35.0 \mathrm{~N}-36.5 \mathrm{E}, I \leq \mathrm{VI}$. A catastrophic earthquake in northwest Syria, felt in Egypt (Abu Shama; Ibn Al-Athir; Ibn Qadi Shuhba).

- Sieberg (1932): 1170 June 29, a destructive earthquake in Syria, killing 2000 persons. Lattakia and half of Hosn Al-Akrad were ruined.
Antioch, Jableh, Tripoli and Jerusalem were also felt. Cyprus, Egypt and Mousel were also felt. Aftershocks lasted for three months.

\section{〈095〉 1287 March 22 Lattakia: VII-VIII;} Palestine: IV; Armenia: IV.

Sources

Saadeh (1984): In the year of 1287 March 22, a violent earthquake occurred in Lattakia, causing damage in some districts of Lattakia and its harbor, especially in the big tower.

Parametric catalogues

- Plassard and Kogoj (1981): 1287-1285, in Lebanon $I=\mathrm{VI}$, it was an earthquake that caused destruction in Lattakia (Abu Al-Faraj; Al-Suyuti; Perrey).

- Ben-Menahem (1979): 1287, $M_{l}=7.3$, destructive in north Syria and Armenia. Lattakia ruined. It was felt in Palestine (Al-Sinawi and Ghaleb; Amiran; Plassard and Kogoj; Sieberg; Willis).

Seismological compilations

- Sieberg (1932): 1287, a strong earthquake in Northern Syria killed a large number of people. Lattakia was the most affected city to the extent that it was completely destroyed. It was felt in Palestine and Armenia.

〈098〉 1322 January 20-February 19 Damascus: V.

Sources

- Ibn Kathir: In this year (722 A.H.) of Muharram (1322 January 20-February 19), a great earthquake was felt at Damascus.

Parametric catalogues

- Plassard and Kogoj (1981): 1322 JanuaryFebruary, $I=I V$, a strong earthquake occurred in Damascus (Al-Suyuti).

<100〉 1344 January 2 Al-Rawendan: VIII; Manbej: VII-VIII; Aleppo: VI-VII; Damascus: IV.

Sources

- Abu Al-Fida: In this year [744 A.H.] of 15 Shaaban [1344 January 2], a great earthquake occurred, causing destruction of Aleppo and its vicinity. In Manbej, destruction was large and many people were killed under debris. Same was in Al-Rawendan castle.

- Ibn Kathir: In this year [744 A.H.] 15 Sha'ban, Saturday [1344 January 2], a slight shock was felt 
by a few people in Damascus. News came from Aleppo mentioning that many houses were destroyed, a few towers of Aleppo citadel, mosques, monuments and walls fell down. Many citadels around Aleppo were destroyed. It was mentioned that most of Manbej had collapsed and most of its inhabitants were killed under the debris.

Parametric catalogues

- Plassard and Kogoj (1981): 1344, I= IV, there was a strong earthquake in Egypt and in Syria (Abu Al-Fida; Al-Suyuti; Perrey).

- Poirier and Taher (1980): 1343 January 1, $I_{0}=$ IX, Manbej was destroyed with 5700 victims. Aleppo fortress was destroyed.

Seismological compilations

- Ambraseys et al. (1994): 1344 January, a large earthquake in SE Anatolia was said to have been felt as far as Egypt (Al-'Aini; Anonymous; Ibn Al-Shihna; Ibn Habib; Poirier and Taher; Sibt Ibn Al-'Ajami; Taher). There is no effects in south of Damascus, where the shock was only slight (Ibn Kathir).

- Sieberg (1932): 1344, an earthquake was in Syria. It was felt in Egypt.

$\langle 110\rangle 1537$ January 7 Antioch: VII; Damascus: IV; Dimyat: IV-V; Egypt: IV.

New original sources

- Al-Ghazi: A slight shock was felt in Egypt and Damascus on 25 Rajab 943 A.H. (07 January 1537) (Badr Al-Ghazi).

Seismological compilations

- Ambraseys et al. (1994): 1537 January 8, Damietta was shaken by earthquakes that continued for four days, five times a day. These shocks may be associated with an earthquake reported to have shaken down many walls in Antioch the same year (Al-'Umari). Alternatively, there may be some connection with the shocks reported in Cairo and Damascus, noted above under 9431537. Such associations imply a large earthquake in or offshore from Northern Syria, for which one would expect further details to be preserved, and it is more likely that the Antioch earthquake, at least, is a separate event.

- Al-Ghouneim (no date): In 944 A.H. (started from 1537 June 10), there was a great earthquake in Antioch where many walls fell down. Later on, Dimyat was shaken for 4 days, 5 times daily (AlJalabi).
〈114〉 1565 July 26 Damascus: V.

New original sources

- Al-Ghazi: A shock occurred on Wednesday early morning, $28 \mathrm{Zu}-\mathrm{l}-\mathrm{Hijja} 972$ A.H. (26 July 1565) in Damascus. It was accompanied by a sound from the earth (Badr Al-Ghazi).

Seismological compilations

- Sieberg (1932): 1566, a destructive earthquake was felt till Cyprus.

\section{〈119〉 1610 March 7 Aleppo: VI.}

New original sources

- Al-Nablsi: A great earthquake hit Aleppo at sunset time on 11 Zu-1-Hijja 1018 A.H. (07 March 1610) (Al-Ghazi).

Seismological compilations

- Ambraseys and Finkel (1995): A contemporary reports that Aleppo and its environs suffered a great earthquake on the evening of Sunday, 11 Zilhicce (Zulhijeh) 1018 A.H. (7 March 1610) (Al-Hafiz).

〈124〉 1626 January 21 Aleppo: VIII-IX; Gaziantab: VIII-IX; Hama: VI-VII; Damascus: V (fig. 11).

Sources

- Al-Nablsi: A slight shock was felt in Damascus on Wednesday 22 Rabi' II 1035 A.H. (21 January 1626). In the meantime an earthquake hit Hama, causing the Souk Al-Dahsheh to collapse and killing many people under the debris (Al-Ghazi).

Seismological compilations

- Ambraseys and Finkel (1995): there was a great earthquake in the Middle East as result of which many places in the region of Aleppo and Gaziantep were ruined with great loss of life (LBS, BDP). This is most probably the earthquake of Wednesday, 22 Rebi-II 1035 A.H. (21 January 1626).

〈134〉 1705 November 24 Yabroud: VIII; AlQastal VIII; Damascus: VII; Tripoli: VII. Aftershocks.

Sources

- Al-Nablsi: He mentioned, as an eyewitness, that three main different sized shocks happened on Tuesday night, 7 Sha'ban 1117 A.H. (24 November 1705) in Damascus. The first one caused general panic while the second was the strong- 


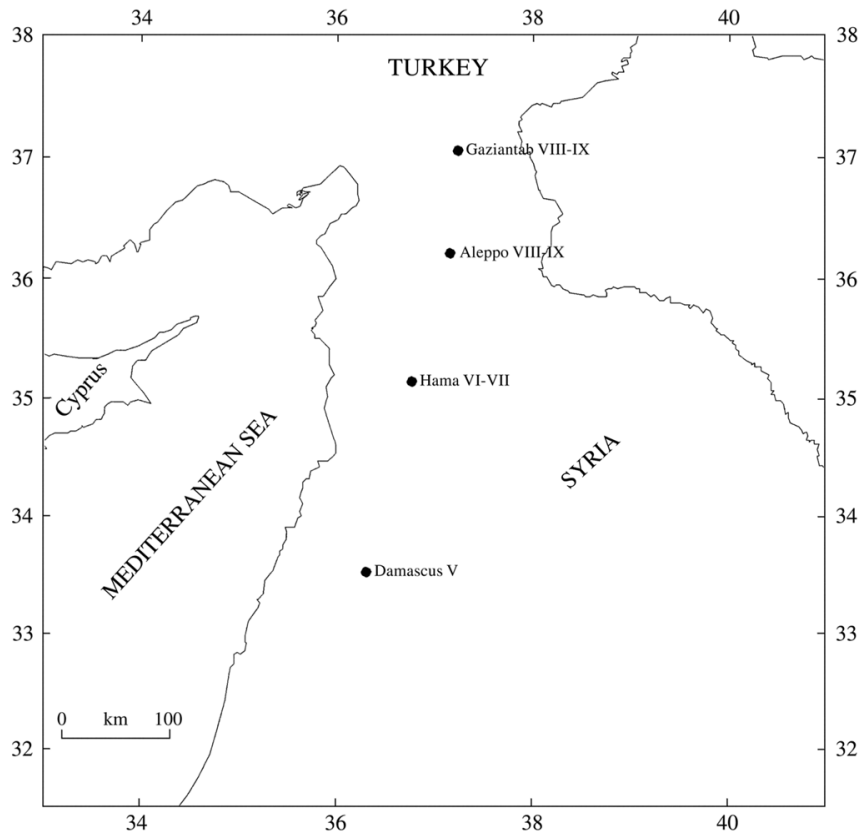

Fig. 11. Map of intensity distribution for January 21, 1626 earthquake.

est, causing houses to fall, walls to be destroyed in and around Damascus and top of the eastern minaret of the Umayyad Mosque to split, upper portion of the Murshidiyah minaret and Al-Afram minaret to fall, to the extent that large number of people in the villages were killed under the debris. In Al-Qastal village, its fortress collapsed as well as a monastery in Yabrud village. Light shocks continued to be felt till Ramadan [aftershocks were felt for one month].

Seismological compilations

- Ambraseys and Finkel (1993): A destructive earthquake occurred on Tuesday night, 7 Sha'ban 1117 A.H. (24 November 1705) in the northern part of the Bekaa Valley in Lebanon. It was preceded by a strong foreshock that caused panic in the area of Damascus. In Damascus, many strong aftershocks occurred, causing some houses to fall, walls to be destroyed, people to be killed in the debris, top of the eastern minaret of the Umayyad Mosque to split, upper portion of the Murshidiyah minaret and Al-Afram to fall. Fortress of Al-Qastal and its villages were de- stroyed. A monastery in Yabrud and many houses in the villages were also destroyed (Al-Nablsi). In Tripoli, roofs and walls of the city, some of the walls of the towers of the coastal fort and some of the quarters of the gar were destroyed.

$\langle 157\rangle 1822$ August 13, 09:50 p.m. (local time) Jisr Ash'Shoughour: IX; Quseir: IX; Aleppo: VIII-IX; Darkoush: VIII-IX; Antioch: VIII; Iskenderun: VIII; Idleb: VIII; Sarmeen: VIII; Kelless: VIII; Armanaz: VII-VIII; Sarmada: VII-VIII; Lattakia: VII; Homs: VII; Hama: VII; Maraash: VII; Ram Hamadan: VII; Bennesh: VII; Maarret Missrin: VII; Damascus: III; Gaza: III; Al-Quds: III; Black Sea: III; Cyprus: III (figs. 12, 13 and 14). Faulting, tsunami.

Parametric catalogues and previous studies - Ambraseys (1989): 1822 August 13, 20:40 (LT), 36.7N-36.9E, $M_{s}=7.4, I_{0}(\mathrm{MSK})=\mathrm{X}$. - Plassard and Kogoj (1981): 1822 August 13, in Lebanon $I=\mathrm{V}$, an earthquake, causing destruction in Antioch, Aleppo and Lattakia with 
tsunami. It was felt in Damascus and Cyprus (Blanckenhorn; Sieberg; Willis).

- Poirier and Taher (1980): 1822 August 13, $I_{0}=\mathrm{X}-\mathrm{XI}$ (MMS), Aleppo destroyed at $60 \%$, sea wave at Iskenderun.

- Ben-Menahem (1979): 1822 August 14,36.4N$36.2 \mathrm{E}, I_{0}=\mathrm{X}-\mathrm{XI}, M_{l}=7.1$, destruction of Antioch and Aleppo. Felt in Jerusalem and Cyprus. Tsunami at Beirut (Amiran; Kárník; Ergin et al.; Plassard and Kogoj; Sieberg).

- Ambraseys and Barazangi (1989): 36.7N36.9E, $M_{s}=7.4$.

Seismological compilations

- Ambraseys (1989): 1822 August 13, this earthquake was the largest in the Border Zone in the last five centuries. It was felt from the coast of the Black Sea to Gaza, and it was followed by an aftershock sequence that lasted almost 2.5 years. The shock almost destroyed the region between Gaziantep and Antakia in Turkey and Aleppo and Khan Sheikhun in NW Syria, killing a very large number of people. Slight shocks began on August 5 and continued until August 12, reported from Aleppo and Antioch. At 8 h 10 min p.m. on August 13 a strong shock was felt in the region between Lattakia, Aleppo and Antioch, causing considerable concern. The main shock happened $30 \mathrm{~min}$ later. Gaziantep and its surrounding villages were almost completely destroyed with great loss of life. Damage was equally heavy in the districts of Shikaghi and particularly of Jum and in the settlements along the Aafrine River. The ground opened up for some distance. The Orontes River overflowed its

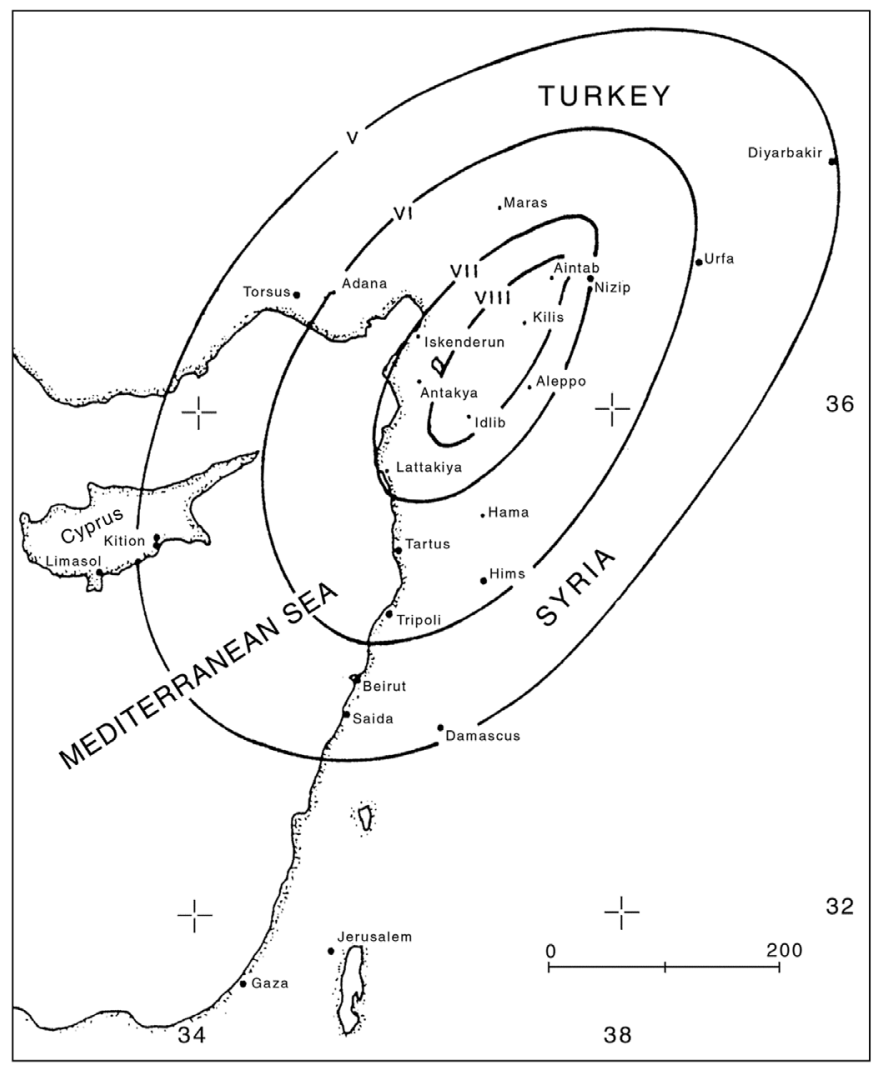

Fig. 12. Map of intensity distribution for August 13, 1822 earthquake (Ambraseys, 1989). 


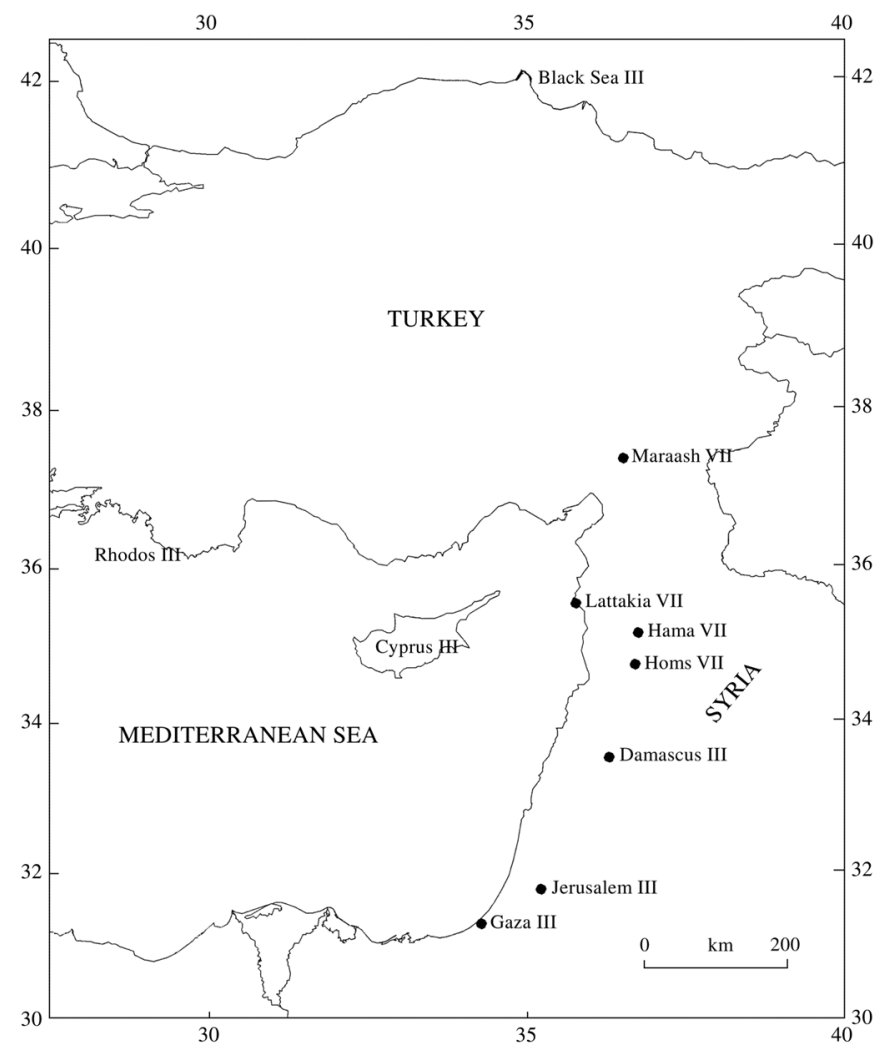

Fig. 13. Map of intensity distribution for August 13, 1822 earthquake.

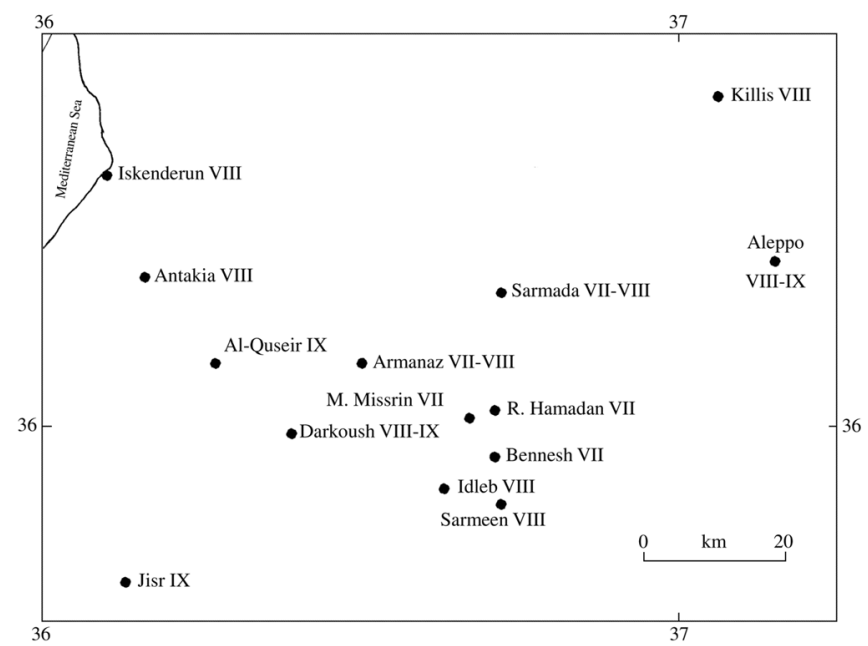

Fig. 14. Detailed map of intensity distribution for August 13, 1822 earthquake, between Antakia and Aleppo. 
banks destroying bridges and embankments. Killis was destroyed with loss of life. Harem and Armanaz were totally destroyed. Darkush was ruined partly and a landslide blocked the Orontes River. Jisr As-Shugr was entirely destroyed with loss of life. Khan Sheikhun, Ariha, Idleb and particularly Maarat were almost completely ruined but the loss of life was not great. Houses collapsed in these places but large buildings, although shattered, were left standing, except in Maarat where they were brought down by aftershocks which also crevassed the banks of the Orontes. It is said that damage extended to Hama and that it suffered as much as Aleppo. Aleppo was ruined with 7000 deaths within the walls of the city. The walls of the citadel were ruined. Many houses, gates and Souks were ruined. It is said that before the earthquake the temperature of well water had increased. Antioch and its surrounding villages were ruined. Many small settlements in the upper and lower Quseir area were razed to the ground and there was a liquefaction of the ground near the town. Beilan was heavily damaged without casualties. In Iskenderun, number of houses were destroyed with liquefaction. At Payas, some houses sunk into the ground but without loss of life. One-third of Lattakia was destroyed and one-third damaged. In Marina, the fort, the mosque and the large khan collapsed, and houses and stores were considerably damaged. Jableh was more heavily damaged and people were killed. Damage was also reported from Markab and the castle of the Crusaders partly collapsed. Villages in the regions of Adana and Misis were ruined. Marash and Nizip also seem to have been affected. Tarsus was strongly affected by this event. At Homs it caused unspecified damage. At Tripoli and its dependencies, it was violent and caused damage. It was strongly felt at Beirut, Sidon, Jerusalem, Gaza, Trabzon, Tokat and Merzifon. It caused panic at Damascus. It was felt in Cyprus and Mesopotamia. It was felt at Urfa, Dyar Bakr and along the Euphrates and caused some damage. Destructive aftershocks occurred in 1822 August 15 and 23, September 5 and 29, October 18 and 1823 June 30, the sequence terminating in 1824 March. The total number of killed people varies between 30000 and 60000 (Consular Archives; Güzelbey and Yetkin; Press Reports).
- Sieberg (1932): 1822 August 13, a vast destructive earthquake in Northern Syria. It was said that 20000 people were killed. Antioch was a victim completely to that earthquake. In Aleppo, 2/3 of houses became not suitable for living and it was said that $1 / 3$ inhabitants were killed. In Iskanderun and Lattakia, there was heavy damage to the houses. It was felt in Adana, Dayr Bakir, Damascus, Jerusalem and Cyprus. Aftershocks continued to the end of June 1823 in Aleppo and Lattakia.

- Al-Tabakh Al-Halabi (1925): Al-Sheikh Bakri Kateb [a religious leader in Aleppo] says that: «In August, many great earthquakes occurred causing the collapsing of the Jewish quarter, the Souk of Perfumery and Al-Aqaba [in Aleppo]. These earthquakes lasted 40 days for every day, collapsing schools and houses in the city [of Aleppo] to the extent people went out of the town. Minerat of the great Mosque was cracked». Jawdat Basha says that: «On the 3rd hour of the night of 6 Zu-L-Hijja 1237 A.H. [1822 August 23], a strong earthquake occurred in Aleppo, Kelless, Antioch and their vicinity, causing many buildings to collapse and large number of people to die under the debris». I [means Al-Tabakh Al-Halabi] catch a poem arranged by Mohammad Taqi edDin who lived in Aleppo during this year [1237 A.H.], describing these earthquakes and their effects in the localities. He says: "An awful earthquake occurred in Aleppo on the night of Wednesday [Tuesday], buildings fell, people were killed, khans collapsed, mosques ruined and the citadel of Aleppo collapsed with falling its stones in the surrounding trench. In Homs, Hama, Marash and Al-Maarat, people were killed. In Ariha and Salqein, the earth faulted. The earth in Gaziaintab and Atareb was shaking. Both Al-Quseir and Jisr Ash'Shougour cities were ruined and people were killed. Houses ruined and people killed in the villages of Aleppo. The ground in Al-Atareb and Ipin sunk. Ram Hamadan suffered. Idlib and Sarmeen became ruined completely. Bennesh and Maarret Missrin were ruined partially. In Darkoush, all houses fell, people were killed and sunk. In Armanaz, houses fell, some inhabitants ran away, others lost and others were injured. Kelless suffered as Aleppo. Sarmada and its vicinity collapsed and people ran away. In Antioch the tower, the city 
wall, khans and houses collapsed». Al-Sheikh Mohammad Al-Termanini from Aleppo (died in 1250 A.H.) says that: "On the 3rd hour of the night of $27 \mathrm{Zu}$-L-Qada 1237 A.H. [1822 August 14] there was an earthquake in and around Aleppo. While we were talking on the 3rd hour of that night, a terrible earthquake occurred causing great panic. At the beginning, we thought it was The Day of Judgment. This earthquake caused the collapse of houses, palaces, and the loss of about 10000 lives. We ran away to the desert. This earthquake caused also the collapse of houses, schools, mosques and soaks that were in front of the gate of the citadel [of Aleppo], starting from Khan Al-Farayin (in the west) to the Salt Square, Al-Mzaweq and Bab Al-Ahmar (in the east), and to the boundaries of Al-Qasileh and Al-Saphahiyya (in the north); only the school of Khessrow Basha, Mosque of Al-Atroush, the school of Al-Sultaniyya and the bath of Al-Nassiryya survived».

- ANF: A terrible earthquake occurred in 1822 August 13 at 09:50 p.m. (local time) lasted for one minute, causing great damage at Aleppo, destroying monuments, minarets, high buildings and walls of Aleppo, and killing many people. At Lattakia, half the city was destroyed and it was more terrible than the 1794 earthquake. Antioch was completely reduced to ruins and many open fractures appeared, producing smoke and lava (?). The Orontes River fled on the neighboring banks, destroying villages, bridges and dams. Iskenderun was destroyed. New springs appeared. The deeply affected area in north west Syria has a radius of $160 \mathrm{~km}$. Villages of Aleppo district were demolished and others swallowed up. The seismic waves had vertical and horizontal components with East West direction. (In fact, this earthquake was followed by many big aftershocks from the date of the main shock up to writing this letter).

\subsection{Re-evaluated seismic events}

In this section we studied each historical earthquake by means of a careful examination of all available references. In addition we restimated all earthquake parameters (intensity, earthquake location, estimated magnitude; see table I) by a unified standard with the aim of providing a homogenous standard list of seismic events with the same characteristics.

$\langle 002\rangle 590$ B.C. Tyre: VII? Tsunami at the Lebanese coast.

Parametric catalogues

- Plassard and Kogoj (1981): 590 B.C., in Lebanon $I=I X$, destruction in Tyre with tsunami. - Ben-Menahem (1979): 590 B.C., $I_{0}=$ IX-X, $M_{l}=6.8$, off Coast epicenter, flooding at Sur, tsunami at Lebanese coasts (Amos, Psal.).

Table I. Parametric catalogue of large historical earthquakes in Syria and its surroundings. The magnitude is calculated following Shebalin (1970), Ambraseys and Barazangi (1989) and Ambraseys (1997).

\begin{tabular}{|c|c|c|c|c|c|c|c|}
\hline No. & $\begin{array}{c}\text { Date } \\
\text { (day.month.year) }\end{array}$ & $\begin{array}{l}\text { Lat. } \\
\left({ }^{\circ} \mathrm{N}\right)\end{array}$ & $\begin{array}{l}\text { Long. } \\
\left({ }^{\circ} \mathrm{E}\right)\end{array}$ & Major affected localities & $\begin{array}{c}I_{0} \\
\text { (EMS-92) }\end{array}$ & $\begin{array}{c}H \\
(\mathrm{~km})\end{array}$ & $M_{s}$ \\
\hline 01 & 37 A.D. & 36.00 & 36.30 & Antioch, Dafneh & VII-VIII & 15 & 6.2 \\
\hline 02 & 53 & 36.20 & 36.50 & $\begin{array}{l}\text { Antioch, Afamia, } \\
\text { Manbej, Lattakia }\end{array}$ & VIII & 30 & 6.6 \\
\hline 03 & $303-304$ & 33.80 & 34.30 & Saida, Sur, Syria & VIII-IX & 20 & 7.1 \\
\hline 04 & 494 & 35.80 & 36.30 & Antioch, Tripoli, Lattakia & VII-VIII & 25 & 6.5 \\
\hline 05 & 22.08 .502 & 33.00 & 34.80 & Akka, Sur, Saida, Beirut, Safad & VIII-IX & 30 & 7.2 \\
\hline 06 & $531-534$ & 35.50 & 37.20 & Area between Aleppo and Homs & VIII & 15 & 6.5 \\
\hline 07 & 09.07 .551 & 34.00 & 35.50 & Cities of Lebanese coast, Arwad & IX-X & 28 & 7.2 \\
\hline 08 & $565-571$ & 36.00 & 36.20 & $\begin{array}{l}\text { Antioch, Seleucea, } \\
\text { Kilikia, Anazrabo }\end{array}$ & VII-VIII & 30 & 6.0 \\
\hline
\end{tabular}


Table I (continued).

\begin{tabular}{|c|c|c|c|c|c|c|c|}
\hline No. & $\begin{array}{c}\text { Date } \\
\text { (day.month.year) }\end{array}$ & $\begin{array}{l}\text { Lat. } \\
\left({ }^{\circ} \mathrm{N}\right)\end{array}$ & $\begin{array}{l}\text { Long. } \\
\left({ }^{\circ} \mathrm{E}\right)\end{array}$ & Major affected localities & $\begin{array}{c}I_{0} \\
(\text { EMS-92) }\end{array}$ & $\begin{array}{c}H \\
(\mathrm{~km})\end{array}$ & $M_{s}$ \\
\hline 09 & 18.01 .747 & 32.50 & 35.60 & $\begin{array}{l}\text { Mt. Tabor, Baalbak, Bosra, Nawa, } \\
\text { Balqa, Al-Quds, Beit Qubayeh, } \\
\text { Tabaryya, Damascus, Daraa }\end{array}$ & IX & 25 & 7.2 \\
\hline 10 & 24.11 .847 & 34.40 & 36.30 & $\begin{array}{l}\text { In and around Damascus, } \\
\text { Antioch, Al-Mosel }\end{array}$ & IX & 35 & 7.5 \\
\hline 11 & $30.12 .859-29.01 .860$ & 35.70 & 36.40 & $\begin{array}{l}\text { Antioch, Lattakia, Jableh, } \\
\text { Homs, Palmyra, Tarsus, Balis, } \\
\text { Damascus, Adana, Ar-Raqqa }\end{array}$ & VIII-IX & 33 & 7.4 \\
\hline 12 & 05.04 .991 & 33.70 & 36.40 & Baalbak, Damascus & IX & 22 & 7.1 \\
\hline 13 & $30.07-27.08 .1063$ & 34.40 & 36.20 & Tripoli, Lattakia, Akka, Sur & VIII & 32 & 6.9 \\
\hline 14 & 11.1114 & 37.30 & 38.50 & Maskaneh, Maraash, & VIII-IX & 40 & 7.4 \\
\hline 15 & 11.1114 & 37.30 & 36.50 & Samsat, Orfa, Harran & IX & 40 & 7.7 \\
\hline 16 & 27.09 .1152 & 32.60 & 36.70 & Bosra, Hauran, Syria & VIII & 12 & 5.8 \\
\hline 17 & 02-04.04.1157 & 35.50 & 36.50 & $\begin{array}{l}\text { Shaizar, Hama, } \\
\text { Kafer Tab, Aleppo }\end{array}$ & VII & 22 & 6.0 \\
\hline 18 & 13.07.1157 & 35.20 & 36.60 & $\begin{array}{c}\text { Hama, Afamia, Kafer Tab, } \\
\text { Homs, Tayma }\end{array}$ & VIII & 25 & 6.6 \\
\hline 19 & 12.08 .1157 & 35.40 & 36.60 & $\begin{array}{c}\text { Shaizar, Kafar Tab, Afamia, } \\
\text { Hama, Arqa, Aleppo, Homs, Lattakia, } \\
\text { Tripoli, Antioch, Qalaat Al-Hosn, } \\
\text { Maarret Annooman }\end{array}$ & IX-X & 15 & 7.4 \\
\hline 20 & 29.06 .1170 & 34.80 & 36.40 & $\begin{array}{l}\text { Damascus, Homs, Hama, Lattakia, } \\
\text { Baalbak, Shaizar, Barin, Aleppo }\end{array}$ & IX & 35 & 7.7 \\
\hline 21 & 20.05 .1202 & 34.10 & 36.10 & $\begin{array}{c}\text { Mount Lebanon, Baalbak, Sur, } \\
\text { Beit Jin, Banyas, Nablus, Al-Samyra, } \\
\text { Damascus, Safita, Akka, Tripoli, } \\
\text { Hauran, Beirut, Homs, Tartus }\end{array}$ & IX & 30 & 7.6 \\
\hline 22 & 02.01 .1344 & 36.70 & 37.40 & Al-Rawendan, Manbej, Aleppo & VIII & 30 & 6.8 \\
\hline 23 & 20.02 .1404 & 35.70 & 36.20 & $\begin{array}{c}\text { Blatnes, Bkas, West of Aleppo, } \\
\text { Qalaat Al-Marqeb, Tripoli, } \\
\text { Lattakia, Jableh }\end{array}$ & VIII-IX & 30 & 7.4 \\
\hline 24 & 29.12 .1408 & 35.80 & 36.10 & $\begin{array}{c}\text { Shugr, Bkas, Blatnes, Lattakia, } \\
\text { Jableh, Antioch, Syrian coast }\end{array}$ & IX & 25 & 7.4 \\
\hline 25 & 10.10 .1568 & 35.50 & 35.50 & Lattakia, Famagusta & VIII & 12 & 6.0 \\
\hline 26 & 21.01 .1626 & 36.50 & 37.10 & Aleppo, Gaziantab, Hama & IX & 20 & 7.3 \\
\hline 27 & 22.09 .1666 & 37.00 & 43.00 & Al-Mousel, Sinjar, Sharqat & IX & 35 & 6.9 \\
\hline 28 & 24.11.1705 & 33.70 & 36.60 & $\begin{array}{l}\text { Yabroud, Al-Qastal, } \\
\text { Damascus, Tripoli }\end{array}$ & VIII & 35 & 6.9 \\
\hline 29 & 15.04 .1726 & 36.30 & 36.60 & Jum, Aleppo & VIII & 15 & 6.1 \\
\hline 30 & 25.09 .1738 & 36.70 & 36.50 & $\begin{array}{l}\text { Iskenderun, Bellen Bass, Antioch, } \\
\text { Jabal Al-Amanus, Aleppo }\end{array}$ & VIII & 10 & 6.2 \\
\hline 31 & 30.10 .1759 & 33.10 & 35.60 & $\begin{array}{l}\text { Al-Qunaytra, Safad, Akka, } \\
\text { An-Nasra, Sidon, Saasaa }\end{array}$ & VIII-IX & 20 & 6.6 \\
\hline 32 & 25.11.1759 & 33.70 & 35.90 & Baalbak, Zabadani, Ras Baalbak, & IX & 30 & 7.4 \\
\hline
\end{tabular}


Table I (continued).

\begin{tabular}{|c|c|c|c|c|c|c|c|}
\hline No. & $\begin{array}{c}\text { Date } \\
\text { (day.month.year) }\end{array}$ & $\begin{array}{l}\text { Lat. } \\
\left({ }^{\circ} \mathrm{N}\right)\end{array}$ & $\begin{array}{l}\text { Long. } \\
\left({ }^{\circ} \mathrm{E}\right)\end{array}$ & Major affected localities & $\begin{array}{c}I_{0} \\
\text { (EMS-92) }\end{array}$ & $\begin{array}{c}H \\
(\mathrm{~km})\end{array}$ & $M_{s}$ \\
\hline & & & & $\begin{array}{l}\text { Al-Qunaytra, Damascus, Beirut, } \\
\text { Saida, Safad, Sur, Tripoli, Homs, } \\
\text { Hama, An-Nasra, Lattakia, Al-Quds, } \\
\text { Gaza, Antioch }\end{array}$ & & & \\
\hline 33 & 26.04 .1796 & 35.30 & 36.20 & $\begin{array}{c}\text { Qalaat Al-Marqeb, Al-Qadmous, } \\
\text { Nahr Al-Kabir, Jableh, } \\
\text { Bkas, Lattakia }\end{array}$ & VIII-IX & 20 & 6.8 \\
\hline 34 & 13.08 .1822 & 36.10 & 36.75 & $\begin{array}{l}\text { Jisr Ash'Shoughour, Quseir, Aleppo, } \\
\text { Darkoush, Antioch, Iskenderun, } \\
\text { Idleb, Kelless, Armanaz, Sarmada, } \\
\text { Lattakia, Homs, Hama, Maraash, Ram } \\
\text { Hamadan, Bennesh, Maarret Missrin }\end{array}$ & 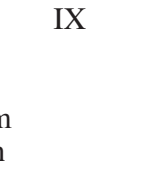 & 18 & 7.0 \\
\hline 35 & 01.01 .1837 & - & - & Safad & VIII & & $>7.0$ \\
\hline 36 & 03.04 .1872 & 36.20 & 36.50 & $\begin{array}{l}\text { Harem, Armanaz, Lake of Al-Amq, } \\
\text { Antioch, Aleppo, Suaidiya, Izaz, } \\
\text { Idleb, Iskenderun }\end{array}$ & VIII-IX & 10 & 5.9 \\
\hline
\end{tabular}

Seismological compilations

- Sieberg (1932): 590 B.C., a great shock occurred, causing a destructive sea wave in Tyre.

〈003〉 525 B.C. Tyre: VIII-IX; Sidon: VIIIIX; Kiklades island: III-IV; Eubea island: IIIIV. Tsunami at the Lebanese coast.

Parametric catalogues

- Plassard and Kogoj (1981): 525 B.C., in Lebanon $I=\mathrm{X}$, destruction in Tyre and Sidon with tsunami, destruction in Bisri (Strabon).

- Ben-Menahem (1979): 525 B.C., off Coast Sur, $I_{0}=\mathrm{XI}, M_{l}=7.5$, Sur destroyed. Sidon greatly damaged. Tsunami at Lebanese coast.

Seismological compilations

- Sieberg (1932): 525 B.C., Sure was completely destroyed. Two thirds of tall buildings in Sidon were ruined. Tsunami in the Lebanese coast. It was felt in Kiklades and Eubea Islands.

$\langle 005\rangle$ 199-198 B.C. Sidon: VIII; Syria: s VII. Landslide at Sidon.

Seismological compilations

- Guidoboni et al. (1994): 199-198, Sidon $I=\mathrm{X}$, a series of shocks felt in Sidon and almost two thirds of it collapsed. A city above Sidon was swallowed up. It was less strongly in Syria with moderate intensity. There was a limited number of victims (Posidonois).

〈007〉 92 B.C. Syria: III-IV; Egypt: III-IV. Tsunami at the Syrian-Lebanese coasts.

Parametric catalogues

- Plassard and Kogoj (1981): 92 B.C., I=VI, strong earthquake felt till Egypt.

- Ben-Menahem (1979): 92 B.C., February 28, SE Cyprus, $M_{l}=7.1$, big tsunami hit Levantine coastal cities. It was felt in Syria, Egypt and Palestine (NSH; Plassard and Kogoj; Talmud; Willis).

Seismological compilations:

- Sieberg (1932): 92 B.C., an earthquake occurred in Syria. It was felt in Egypt.

$\langle 008\rangle$ 65 B.C. Syria: VII-VIII; Antioch: VIIVIII; Al-Quds: VI; Cyprus: III-IV; Salamis: III-IV; Famagusta: III-IV.

Parametric catalogues

- Plassard and Kogoj (1981): 69 B.C., I=IV, destruction in Antioch.

- Ben-Menahem (1979): 64 B.C., $M_{l}=7.7$, $36.2 \mathrm{~N}, 36.1 \mathrm{E}$, destruction of Antioch. It was 
felt in Cyprus. damage to the temple walls in Jerusalem (Amiran; Plassard and Kogoj; Sieberg; Willis; Yebamoth).

Seismological compilations

- Sieberg (1932): 69 B.C., a heavy earthquake destroyed many cities in Syria. Antioch was included in this destruction. It was said that 17000 people were killed in Syria. Shocks reached Palestine and Cyprus (Salamis and Famagusta).

- Guidoboni et al. (1994): 65 B.C., Antioch, Syria IX $\leq I \leq X I$, a destructive earthquake hit Antioch causing one hundred and seventy thousands deaths and destroyed many cities (Pompeos Trogus and Malalas).

〈009〉 37 B.C. March 23, morning Dafneh: VI-VII; Antioch: V.

Seismological compilations

- Guidoboni et al. (1994): 37 B.C. March 23, Antioch suffered and Dafneh was damaged (Malalas).

$\langle 010\rangle 19$ A.D. Sidon; Palestine; Syria; Asia Minor.

Parametric catalogues

- Plassard and Kogoj (1981): 19 A.D., in Lebanon $I=\mathrm{VI}$, a strong earthquake at Sidon (Sieberg).

- Ben-Menahem (1979): 19 A.D., off coast Sidon, $I_{0}=\mathrm{IX}-\mathrm{X}, M_{l}=6.8$, destruction at Sidon. It was felt in Palestine, Syria and Asia Minor (Amiran; Plassard and Kogoj; Willis).

Seismological compilations

- Sieberg (1932): 19 B.C., an earthquake was in Sidon.

〈011〉 37 A.D. Antioch: VII-VIII; Dafneh: VII; Al-Quds: IV.

Parametric catalogues

- Plassard and Kogoj (1981): 37 A.D., I=IV, a destructive earthquake at Antioch. It was felt at Jerusalem (Sieberg).

Seismological compilations

- Guidoboni et al. (1994): Antioch, Daphne $\mathrm{VIII} \leq I \leq \mathrm{X}$, Antioch suffered from an earthquake in the morning of 23 March 37. Dafneh area was also damaged (Malalas).

- Sieberg (1932): 37 B.C., a destructive earthquake in Antioch. It was felt in Jerusalem.
〈012〉 47 Antioch: VII.

Seismological compilations

- Guidoboni et al. (1994): 47 A.D., Antioch $\mathrm{VIII} \leq I \leq \mathrm{X}$, a violent earthquake in Antioch (Philostratus). Antioch was shaken by an earthquake where the famous palaces collapsed and cracks appeared in many temples (Malalas).

〈013〉 53 Antioch: VII-VIII; Afamia: VI-VII; Manbej: VI-VII; Lattakia:VI-VII (fig. 15).

Parametric catalogues

- Plassard and Kogoj (1981): 53 A.D., I= IV (in Lebanon), destructive earthquake at Antioch, Apamea and Lattakia (Sieberg).

- Poirier and Taher (1980): 52 A.D., $I_{0}=$ VIIIIX (MMS), destruction in Antioch.

Seismological compilations

- Sieberg (1932): 53 A.D., there was an earthquake in Syria. In Antioch, temples of Diana and Hercules were destroyed. There was heavy damage in Menbej, Lattakia, Apamia.

〈014〉 82-94 Antioch: VI-VII, Syria. Aftershocks.

Seismological compilations

- Sieberg (1932): between 82-94 A.D., a strong widespread earthquake struck Syria causing destruction of many houses at Antioch. Shocks lasted for 40 days.

〈015〉 115 December 13 Antioch: VII; Eleyah: VI-VII; Mirana: VI-VII; Rhodos: IV; Pitana. Tsunami at Caesaria, the Lebanese coast and Yavne.

Parametric catalogues

- Plassard and Kogoj (1981): 115 December 3, $I=$ VII (in Lebanon). It has an intensity VII at Beirut and all the Lebanese Coast. It was destructive at Antioch (Shalem).

- Poirier and Taher (1980): 115 A.D., $I_{0}=\mathrm{X}-\mathrm{XI}$ (MMS), heavy destruction in Antioch.

- Ben-Menahem (1979): 115 December 13, at night, near Samandag, $M_{l}=7.4$, it was felt all over the near east and the Eastern Mediterranean up to Rhodos. Destruction of Antioch. Tsunami hit Yavne and Caesaria in Palestine (Ergin et al.; Plassard and Kogoj; Shebalin et al.; Sieberg; Willis).

Seismological compilations

- Guidoboni et al. (1994): 115 December 13, 


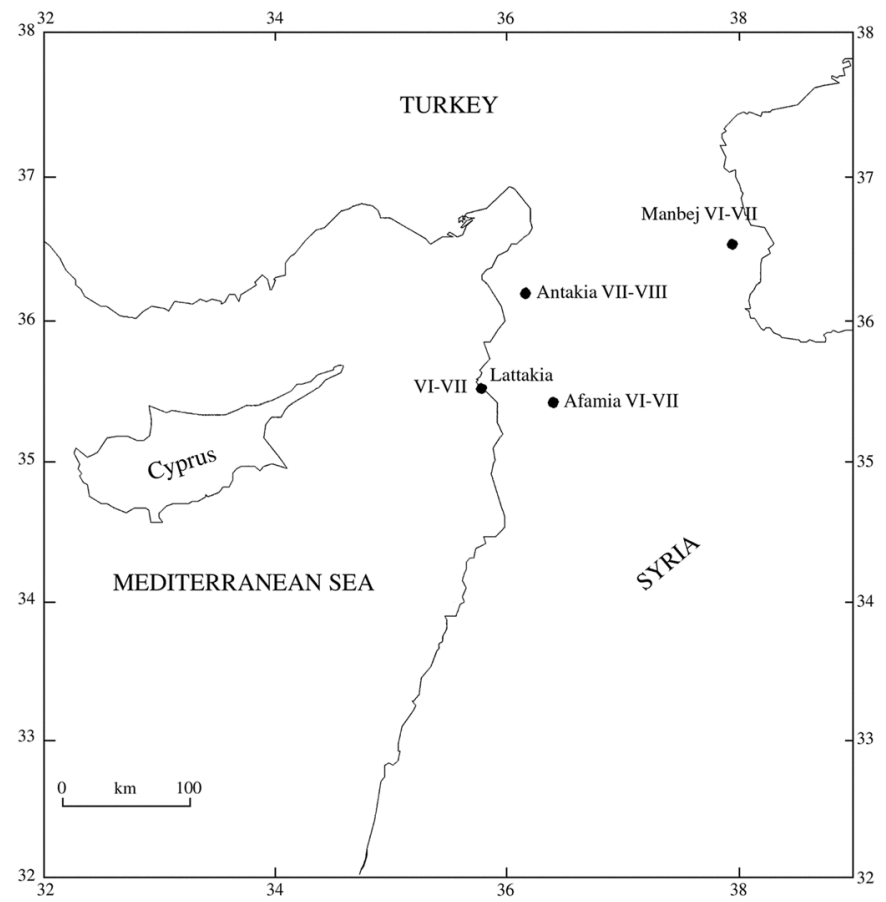

Fig. 15. Map of intensity distribution for the 53 A.D. earthquake.

Antioch $\mathrm{IX} \leq I \leq \mathrm{XI}$, Antioch was struck by a violent earthquake, many cities were badly damaged, buildings were thrown into the air, large number of casualties and injured (Dio Cassius). Antioch, near Daphne, suffered from this earthquake (Malalas). An earthquake in Antioch (Incomplete Fragment XXXV in the Fasti Ostiensis). - Sieberg (1932): 115 December 13, at night, an earthquake destroyed two thirds of Antioch. 1600 victims. Destruction of Eleyah, Mirina and Pitana (near Antioch). It was felt in Rhodos.

〈016 130 Damascus: V-VI; Baalbak: V; Eastern Mediterranean region. Aftershocks.

Parametric catalogues

- Plassard and Kogoj (1981): in 130, there was an earthquake in Syria and Palestine. It was strongly felt in Baalbak.

- Ben-Menahem (1979): $M_{l}=6.1$, strong in Damascus (Plassard and Kogoj; Sieberg; Willis).

Seismological compilations

- Sieberg (1932): 130, a strong earthquake in
Damascus and many aftershocks lasted for the next year.

- Lemmens (1898): in 131 A.D., there was an earthquake in the Eastern Mediterranean region and Syria.

$\langle 017\rangle 160$ October Dura Europos: $\mathbf{z}$ VI.

Seismological compilations

- Guidoboni et al. (1994): a morning in October 160, an earthquake struck Dura Europos (Baur and Rostovtzeff, 1931).

〈018 220 Antioch: VI. Aftershocks.

Seismological compilations

- Sieberg (1932): 220 A.D., a destructive earthquake in Antioch. It was followed by a large number of shocks.

$\langle 019\rangle 233$ Damascus: VII.

Parametric catalogues

- Ben-Menahem (1979): 233 A.D., $M_{l}=6.3$, damage in Damascus. 
Seismological compilations

- Sieberg (1932): 233 A.D., there was an earthquake in Syria causing destruction of many houses at Damascus.

$\langle 020\rangle$ 242-245 Antioch: VI-VII; Syria: VIVII; Egypt: III; Iran: III.

Parametric catalogues

- Ben-Menahem (1979): 245, $M_{l}=7.5$, near Antioch (Willis).

Seismological compilations

- Sieberg (1932): 242 or 245, a strong earthquake in Antioch and all over Syria. It was felt in Egypt and Iran.

〈021〉 272 Antioch: VI; Syria: VI.

Seismological compilations

- Sieberg (1932): 272 A.D., a strong earthquake in Antioch and all over Syria.

$\langle 022\rangle$ 303-304 Sidon: VIII; Tyre: VIII; Syria: VII; Al-Quds: III-IV. Tsunami at Caesaria.

Parametric catalogues

- Plassard and Kogoj (1981): 306 A.D., in Lebanon $I_{0}=\mathrm{IX}$, it was a destructive earthquake at Tyre and Sidon. There was a tsunami in Caesaria (Cesare) in Palestine (Eusèbe; Perrey).

- Ben-Menahem (1979): 306-308, off coast Sur, $I_{0}=\mathrm{X}, M_{l}=7.1$, destruction at Sur and Sidon. Felt in Jerusalem. Tsunami at Caesaria (Amiran; Plassard and Kogoj; Sieberg; Willis).

Seismological compilations

- Guidoboni et al. (1994): 303-304, Sidon IXs $\leq I \leq X I$, a terrible earthquake caused many buildings to collapse at Tyre and Sidon, and a large number of people were killed (Chronicon of Eusebius). An earthquake followed in Syria, as a result of which buildings collapsed everywhere, and thousands of people were crushed in Tyre and Sidon (Orosius). A date 303 for this event was mentioned by Hermann (1962).

- Russell (1985): 306, a terrible earthquake at Tyre and Sidon threw down many buildings, and in-numerable people were crushed (Chronicon of Eusebius). A date $c a .303$ may be more nearly cor-rect (Ambraseys). Russell believes that sites in the Galilee would have been affected by this event.
- Sieberg (1932): 306, a strong earthquake in Syria. Tyre and Sidon were destroyed. The earthquake was felt in Jerusalem.

<023〉 341 Antioch: VI-VII; Beirut: VII. Aftershocks.

Parametric catalogues

- Ben-Menahem (1979): 334, $M_{l}=7.0$, destruction of Antioch. Felt all over the near east (Ergin et al.; Sieberg; Willis).

- Plassard and Kogoj (1981): 344, destruction in Cyprus, in Lebanon I = IV (Theophanes; Perrey). - Poirier and Taher (1980): 340, $I_{0}=$ IX (MMS), heavy destruction in Antioch.

- Ergin et al. (1967): an earthquake was in Antioch.

Seismological compilations

- Guidoboni et al. (1994): 341 A.D., a series of earthquakes occurred in the Eastern Mediterranean and in particular at Antioch for the whole year (Socrates). The church of Arian collapsed (Michael the Syrian). In the year 341, Antioch was shaken by a violent earthquake for three days (Theophanes). An earthquake at Antioch lasted for three days in the year 341-342 (Cedrenus).

- Sieberg (1932): In 334, a strong earthquake in Syria and the near East. It was said there were 40000 victims. Antioch was destroyed. In 340, an earthquake destroyed Beirut, killing a large number of people. In 341, a destructive earthquake in Antioch, followed by many shocks.

〈024 348-349 Beirut: VII; Arwad: VI. Tsunami?

Parametric catalogues

- Plassard and Kogoj (1981): 349, I=X, a destructive earthquake at Beirut, $I=\mathrm{X}$ or IX, where most of the city was destroyed (Anstase). - Ben-Menahem (1979): 349-348, off coast Beirut, $I_{0}=\mathrm{X}, M_{l}=7.0$, Syrian coast. Destruction at Beirut (Plassard and Kogoj; Sieberg; Willis).

Seismological compilations

- Guidoboni et al. (1994): 348-349, Beirut $\mathrm{VIII} \leq I \leq \mathrm{IX}$, a powerful earthquake destroyed most of Berytus (Theophanes; Cedrenus). Grumel in 1958 dates it to 348 .

- Sieberg (1932): 348, a destructive earthquake in the Syrian coast, causing damage in Beirut and Arwad with tsunami. 
$\langle 025\rangle 363$ May 18-19, night This earthquake destroyed Palestine and parts of Jordan, Panyas: VII.

Seismological compilations

- Guidoboni et al. (1994): 363 May 18-19 night, Jerusalem, Sebastia and Nicopolis $I=X$. A furious storm and earthquake occurred in Jerusalem, and the fire broke out in the temple and there was a light in the sky in the form of a cross (Gregory of Nazianzus). On the night, a mighty earthquake tore up the stones of the old foundations of the temple, and dispersed them all together with the adjacent edifices. Fire came down from heaven and consumed all the builders' tools (Socrates; Sozomen; Philostor-gius; Theodoret). The land shook considerably, and there were great tremors in the towns round about. Many Christians and the majority of the Jews perished in that scourge not only by the earthquake but also as a result of fire and in the heavy rain they had. More than half of Beit Gubrin, part of Baishan, Sebastia and its territory, Nicopolis and its territory, more than half of Lydda and its territory, about half of Ascalan, Antipatris and its territory, part of Caesarea, more than half of Samaria, a third of Paneas, half of Azotus, part of Gophna, more than half of Petra, more than half of Hada, a suburb of Jerusalem, more than half of Jerusalem. Fire came forth and consumed the teachers of the Jews. Part of Tiberias and its territory, more than half of Areopolis, Sepphoris and its territory, Aina d-gader, Haifa flowed with blood for 3 days, Japho perished. This event took place on Monday at the third hour, and partly at the ninth hour of the night. There was great loss of life here. It was on 19 Iyyar of the year 674 [May 363] of the kingdom of Alexander the Greek (Cyril of Jerusalem?). In 365 July 21, a great earthquake occurred in Areopolis, and the sea swept in over the shores of the whole wold, and the city walls collapsed that same night (Jerome in his Commentary on Isaiah). Many cities in Palestine were destroyed (Libanius). 21 cities were destroyed (Chronicle of 724; Chronicon Maroniticum). 22 cities were destroyed (Agapius of Menbij). It was a sudden fire rather than an earthquake (Ammianus; Ambrose; John Chrysostom). The Temple was destroyed (Coptic source). It was wrongly taken to be the 365 earthquake (Amiran).
- Russell (1985): 363 May 19, such as Cyril of Jerusalem' description as above.

- Sieberg (1932): 362, before June, a strong earthquake occurred at the eastern bank of the Dead Sea, causing a flood. Cities of Areopolis and Kerak were destroyed. At Jerusalem, the Temple suffered.

\section{〈026〉 394-396 Antioch: V-VI.}

Parametric catalogues

- Poirier and Taher (1980): 394 and 396, $I_{0}=$ IX (MMS), heavy destruction in Antioch.

Seismological compilations

- Sieberg (1932): 396, a strong earthquake in Antioch.

\section{$\langle 027\rangle$ 450-457 September Tripoli: VI-VII.}

Parametric catalogues

- Plassard and Kogoj (1981): 457, I=IV, a destructive earthquake at Antioch (Cedrenus; Perrey).

Seismological compilations

- Guidoboni et al. (1994): 450-457 September, Tripoli VIII $\leq I \leq \mathrm{X}$, Tripoli in Syria suffered from the wrath of God, at night (Malalas).

- Sieberg (1932): In 445, a strong earthquake was in Tripoli.

\section{〈028〉 458 September Antioch: VII-IX.}

Parametric catalogues

- Poirier and Taher (1980): 458, $I_{0}=$ IX (MMS), 80000 victims in Antioch.

Seismological compilations

- Guidoboni et al. (1994): 458 September 1314 , Antioch VIII $\leq I \leq$ IX, a destructive earthquake struck Antioch with a large number of victims and homeless and habitant ran towards the mountain tops (Severus of Antioch). A dreadful trembling and shaking of the earth occurred in Antioch, destroying nearly all the buildings in the new city, towers and baths (John of Rhetorician). Antioch suffered its fourth calamity on Sunday 13th September (Malalas). Two parts of Antioch were destroyed and caused many deaths (Chronicle of 724). It was between 456 to 459 A.D. (Pseudo-Dionysius of Tellmahre). It was a terrible earthquake in 457-458 causing nearly all the city to reduce to ruins (Theophanes). It was in 457 (Cedrenus). 
- Sieberg (1932): 457-458, a strong earthquake in Northern Syria destroyed a large part of Antioch.

〈029 475 September Jableh: VII-VIII.

Seismological compilations

- Guidoboni et al. (1994): 475 September, Jableh VIII $\leq I \leq \mathrm{X}$, Jableh suffered (Malalas). It was dated on 478-479 (Pseudo-Dionysius of Tellmahre).

- Sieberg (1932): In 477, a strong earthquake in Jableh. In 479, a strong earthquake destroyed a large number of houses in Syria.

$\langle 030\rangle 494$ Antioch: VII; Tripoli: VI-VII; Lattakia: VI-VII; Beirut: V.

Parametric catalogues

- Plassard and Kogoj (1981): 494 or 492, I= VIII, a destructive earthquake at Tripoli, causing panic at Beirut (Zacharie le Scolastique).

Seismological compilations

- Sieberg (1932): 494 A.D., 90 villages and cities in Syria were destroyed. Laodicea and Tripoli were among these cities. The walls of Antioch fell down.

〈031 500 Antioch; Seleucea; Orfa; Safad.

Parametric catalogues

- Ben-Menahem (1979): 500, 36.2N, 36.1E, $I_{0}=\mathrm{XI}, M_{l}=7.5$, destruction of Antioch. Damage to Safad. It was felt in Turkey and Greece (Amiran; Plassard and Kogoj; Sieberg; Willis). - Ergin et al. (1967): an earthquake was in Samandag and Urfa.

Seismological compilations

- Sieberg (1932): 500, a heavy earthquake in Syria. It reached Palestine. Large destruction in Antioch and Seleucea. There was damage in Edessa and Safad.

〈033〉 525 May Beirut: VII-VIII; Byblus: VII-VIII; Sidon: VI-VII; Antioch: VI-VII. Aftershocks.

Parametric catalogues

- Ben-Menahem (1979): 525 May 29, off coast Sidon, $\mathrm{I}_{0}=\mathrm{IX}-\mathrm{X}, M_{l}=6.7$ (Ergin et al.; Plassard and Kogoj; Sieberg; Willis).

Seismological compilations

- Sieberg (1932): 525 May, a strong earthquake occurred in the coastal area of Syria with a large number of deaths. Berytos and Byblos were completely destroyed. In Sidon and Antioch, there was heavy damage to the buildings. Aftershocks continued till October.

$\langle 038\rangle 553$ Antioch: V.

Seismological compilations

- Sieberg (1932): in 553, a strong earthquake was in Antioch.

$\langle 039\rangle 557$ Antioch: V.

Seismological compilations

- Sieberg (1932): in 557, a strong earthquake was in Antioch.

$\langle 045\rangle 639$ Antioch: IV-V

Seismological compilations

- Sieberg (1932): 639, a strong earthquake with a horrible noise occurred in Antioch.

〈051〉 775 Antioch: IV.

Seismological compilations

- Sieberg (1932): 775, an earthquake was at Antioch.

〈052〉 791 Aleppo: V; Northern Syria; Palestine.

Seismological compilations

- Sieberg (1932): 791, a strong earthquake in Aleppo and Northern Syria. It reached Palestine.

$\langle 053\rangle$ 8th century Ar-Rassafeh: VII-VIII. Other works

- Klengel (1985): During the 8th century, ArRassafeh hit by a strong earthquake, transferring its buildings into ruins.

$\langle 059\rangle 881$ May 16 Syria; Egypt; Mesopotamia; North Africa and Al-Andalus.

Seismological compilations

- Guidoboni et al. (1994): In that year [267 A.H., 12 August 880-31 July 881], there was a strong earthquake in Syria, Egypt, some parts of Mesopotamia, North Africa and Andalusia (Ibn Al-Athir).

$\langle 060\rangle 889$ Aleppo: III-IV.

Seismological compilations:

- Sieberg (1932): 889, several size-varied shocks $(\sim 6)$ occurred in Aleppo. 
$\langle 061\rangle 894$ Northern Syria.

Seismological compilations

- Sieberg (1932): 894, an earthquake occurred in Northern Syria. It was felt in Armenia and Palestine.

$\langle 062\rangle$ 951 June 9-952 May 28 Aleppo: V-VI; Raaban?; Duluk ?; Tal Hamed ? Aftershocks. Parametric catalogues

- Poirier and Taher (1980): 951 September, $I_{0}=$ VIII-IX, heavy destruction in Aleppo. Raaban and Duluk were destroyed.

Seismological compilations

- Guidoboni et al. (1994): 951 June 9-952 May 28, Aleppo VIII $\leq I \leq \mathrm{X}$, Duluk, Raaban, and Tall Hamid. In that year (9 June 951-28 May 952) there were many earthquakes in Aleppo and other cities, they lasted for 40 days, causing many victims and destroying the strongholds of Tall Hamid and those of the towns of Raaban and Duluk, three towers of the latter collapsed (Ibn Tagri Birdi).

〈063〉 963 July Izaz: VII; Northern Syria: VI. Rock-falls.

Seismological compilations

- Seiberg (1932): 963 July, Izaz was destroyed by an earthquake. Many other places in Northern Syria were damaged. It was accompanied by rock-falls.

〈064〉 972 Antioch: VI-VII; Damascus: V. Parametric catalogues

- Plassard and Kogoj (1981): 972-3, I=III, a strong earthquake occurred in Al-Sham (= Southern Syria) (Al-Suyuti).

- Poirier and Taher (1980): 972, $I_{0}=$ IX (MMS), Antioch, Emperor Johannes Shamshik sent 12000 workers to rebuild the city.

Seismological compilations

- Guidoboni et al. (1994): 972, Antioch VII $\leq$ $\leq I \leq$ VIII and Damascus. There was an earthquake in Antioch, and a large part of its walls collapsed (Al-Antaki). An earthquake affected Damascus and surrounding area, many towers in Antioch collapsed (Al-Maqrizi).

〈065〉 991 April 5, night Baalbak: VIII-IX; Damascus: VII-VIII; Egypt: III-IV. Landslide, tsunami, aftershocks.
Parametric catalogues

- Plassard and Kogoj (1981): 991 April 5, I= VII, this earthquake caused destruction of 1000 houses at Damascus and a village near Baalbak (Erpenius).

Seismological compilations

- Guidoboni et al. (1994): Baalbak and Damascus $I=$ IX. On the night of 5 April 991, there was an earthquake at Damascus collapsing more than 1000 houses and a large number of people died, a village near Baalbak was swallowed up by the earth, other tremors occurred in Damascus and the surrounding area of Baalbak (Al-Antaki).

- Seiberg (1932): 991 April 5, an earthquake occurred in Syria. It was accompanied by a tsunami. In Damascus, more than 1000 houses collapsed with many victims. A village near Baalbak vanished. Aftershocks lasted for six weeks. The earthquake was felt in Egypt.

- Ben-Menahem (1979): 991 April 5, $I_{0}=$ IX-X, $M_{l}=6.5$, great destruction and many casualties in Damascus and Baalbak. Felt as far as Egypt (Plassard and Kogoj; Seiberg; Willis).

〈071〉 1089 Palmyra: $\geq$ VIII.

Seismological compilations

- Sieberg (1932): 1089, a strong earthquake was in Syria. It ruined Palmyra.

〈074〉 1098 January Antioch: III; Aleppo: III. Seismological compilations

- Sieberg (1932): 1098 January, a slight earthquake was in Antioch, Aleppo and other places in Northern Syria.

$\langle 076\rangle 1128$ Tyre. Surface faulting?

Seismological compilations

- Sieberg (1932): 1128, a destructive earthquake killed a large number of people in Sure. Cracks appeared in the ground.

$\langle 077\rangle 1135$ Syria.

Seismological compilations

- Sieberg (1932): 1135, an earthquake was in Syria.

〈080〉 1139 Aleppo.

Seismological compilations

- Sieberg (1932): 1139, many strong shocks occurred in Aleppo for two weeks. 
〈085〉 1182 Bosra: VII; Judea: VI; Nablus: VI. Parametric catalogues

- Ben-Menahem (1979): 1182, 32.6N, 36.7E, Jabal Al-Arab, $I_{0}=\mathrm{IX}-\mathrm{X}, M_{l}=6.7$, destructive at Bosra and Southern Syria. Destructive in Judea and Nablus (Amiran; Plassard and Kogoj; Seiberg; Willis).

Seismological compilations

- Sieberg (1932): 1182, a destructive earthquake hit Southern Syria. It was felt in Judea.

〈086〉 1202 May 20, early morning Mount Lebanon: IX; Baalbak: IX; Tyre: IX; Nablus: VIII; Beit Jin: IX; Banyas: VIII+; Al-Samyra: VIII+; Damascus: VIII; Safita: VII; Akka: VII; Hauran:VIII; Hama: VIII; Tripoli: VIII; Safad: VII; Al-Quds: VI; Bosra: VII-VIII; AlBatron: VII; Jbeil: VII; Beirut: VII; Marqab and Hosn Al-Akrad: VII; Barin: VII; Homs: VII; Tartus: VI; Aleppo: V; Antioch: V; AlMousel: IV-V; Mesopotamia: IV; Cairo: IV; Alexandria: IV; Dimyat: IV; Qus: IV; Iraq: IV; Cyprus: VII?; Lesser Armenia: IV; Sicily: IV; Khlat: IV; Ceuta: III?; Constantinople: IV (fig. 16). Tsunami, landslide, aftershocks.

Parametric catalogues

- Plassard and Kogoj (1981): 1201 June and July, $I=\mathrm{X}$, there was an earthquake that caused a destruction in Tyr, Beirut, Damascus, Baalbak, Palestine (Nablus, Acre and Safad), and Homs in Syria, with tsunami in Cyprus (Al-Suyuti; Ernoul; Perrey).

- Ben-Menahem (1979): 1201 July-August, $34.5 \mathrm{~N}, 36.8 \mathrm{E}, I_{0}=\mathrm{XI}, M_{l}=7.3$, felt in Mesopotamia, Anatolia, Upper Egypt, Cyprus. Destructive in Tripoli, Sur, Acre, Nablus. Many monuments and temples at Baalbak collapse. Many victims (Al-Sinawi et al.; Amiran; Ergin et al.; Plassard and Kogoj; Seiberg; Willis).

- Ben-Menahem (1979): 1202, May 20, at down, $32.5 \mathrm{~N}, 35.5 \mathrm{E}$, near Bissan, $I_{0}=\mathrm{X}-\mathrm{XI}$, $M_{l}=6.8$, destruction in Central Palestine. Nablus destroyed. Safad, Bissan and Banyas experienced $M_{M}=\mathrm{IX}$. It was felt in Syria, Cyprus, Egypt and Mesopotamia. Jerusalem $M_{M}=$ V. Acre $M_{M}=$ VIII. Tiberias $M_{M}=$ IX, damage to the city walls (Al-Sinawi and Ghalib; Amiran; Plassard and Kogoj; Sieberg).

Seismological compilations

- Ambraseys et al. (1994): 1202 May 20,

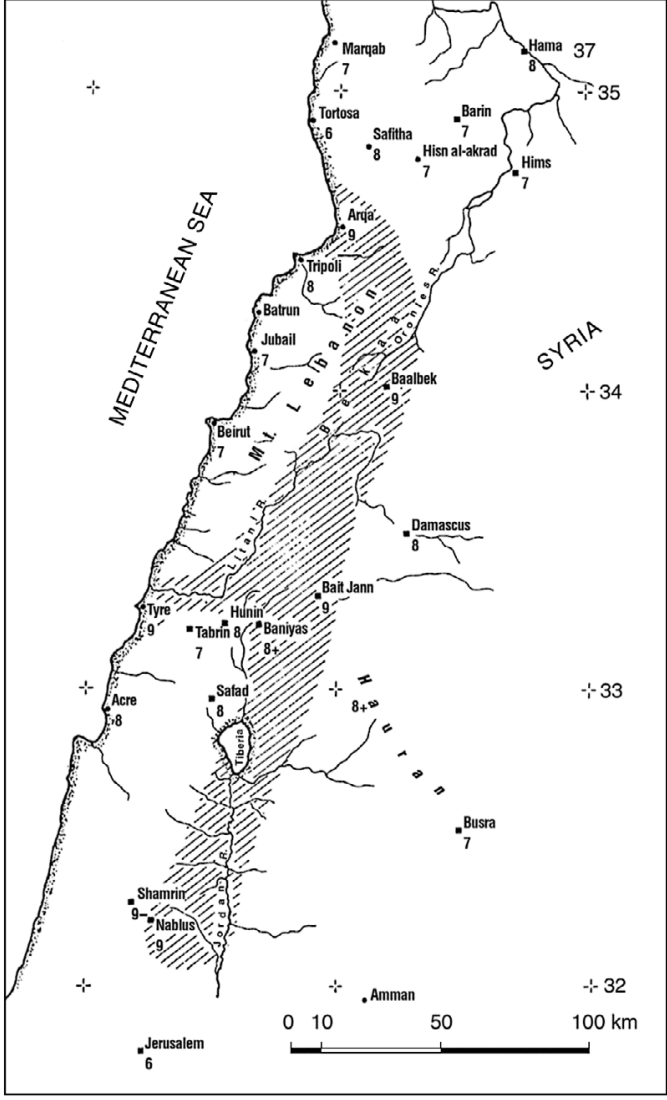

Fig. 16. Map of intensity distribution for May 20, 1202 earthquake (Ambraseys and Melville, 1985). Shaded zone is the most affected region.

$33.5 \mathrm{~N}-36.0 \mathrm{E}, \mathrm{VI} \leq I \leq \mathrm{VII}$, tsunami and faulting. A major earthquake in the upper Jordan and Litani Valleys was responsible for tens of thousands of casualties in the Eastern Mediterranean region, it was felt throughout Egypt, causing great concern but little damage (Abd Al-Latif). The main shock was felt from Sicily to Azarbaijan in NW Iran, and from Constantinople to Aswan (Ambraseys and Melville). - Sieberg (1932): 1202 May 20, a strong earthquake at Samaria and Galilia, causing a large number of victims and destroying Nablus. Ak$\mathrm{ka}$ and Safad were suffered. There was a large sea wave along the Syrian coast destroying 
many ships and settlements. In 1202, a destructive earthquake destroyed Baalbak. There was destruction in Homs and Crac des Chevaliers. It was felt in Mesopotamia and Cyprus.

\section{Monographs}

- Ambraseys and Melville (1988): A shallow, large magnitude multiple earthquake was widely felt in the Middle East around daybreak on the morning of 20 May 1202. The main shock was felt from Lesser Armenia, parts of Anatolia and northwest Iran to Qus in upper Egypt, and from Sicily in the west to Iraq and Mesopotamia in the east (radius of $1200 \mathrm{~km}$ ). It was associated with tsunamis. This event caused serious damage in Syria and to a lesser extent in Cyprus, with great loss of life. The epicenter was evaluated to be $34.1 \mathrm{~N}$ and 36.1E, with estimated magnitude $M_{s}=7.5$. Both Acre and Tyre were severely damaged with heavy loss of life. Contemporary letters (Mayer, 1972) speak of damage to walls and towers in both cities, including the palace at Acre. The house of the Temperas in Acre was spared. All but 3 towers and some outlying fortifications were destroyed in Tyre, along with churches and many houses. Intensities in Tyre may be assessed higher than those in Acre, respectively around IX and VIII. In Shamrin (Samaria) and Houran, damage was equally severe (VIII). Safad was partially destroyed, with the loss of all (VIII). At Bait Jann, not even the foundations of walls remained standing, everything having been swallowed up (IX). In Nablus, there was total destruction (IX). In Houran province, most of the towns were so badly damage (Abd Al-Latif; Sibt Al-Jwazi). One of the villages around Busra is said to have been completely destroyed, perhaps by landslides (Ibn Al-Athir). Jerusalem suffered relatively lightly (Abd Al-Latif) at intensities not exceeding VI. Damascus was strongly shaken (VIII): a large number of houses collapsed, major buildings near the citadel were damaged, the Umayyad mosque lost its eastern minaret and 16 ornamental battlements along its north wall, one man was killed in the collapse of the Jirun gate of the mosque, the lead dome of the mosque was split in two and one other minaret fissured (Le Strange), the Kallasa mosque was ruined, killing a North African and a Mamluk slave (Abu Sha- ma). The shock in Damascus was of long duration. Another slight shock was felt early on the following morning (Abu Shama), and aftershocks continued for at least four days ("Abd Al-Latif). In Jubail, houses are said to have collapsed (VII). The walls of Beirut are said to have been repaired around this time following earthquake damage (VII). Rockfalls in Mount Lebanon overwhelmed about 200 people from Baalbak. Baalbak itself was destroyed ('Abd AlLatif) (IX). In Tripoli, there was heavy loss of life (Mayer) and heavy damage (Ibn Al-Athir) (VIII). Tartus and the Templar citadel seem largely to have been spared (Berchem and Fatio; Enlart) (VI). The strongholds at Marqab and Krak (Hosn Al-Akrad) were badly damaged (Geoffrey of Donjon; Sibt Al-Jawzi) (VII). Castle of Barin was also damaged (Abd Al-Latif) (VII). In Homs, the shock was experienced at similar intensities (VII), where a watchtower of the castle was thrown down (Sibt Ibn Al-Jwazi). The earthquake in Hama was experienced as two shocks, destroying its castle, along with many houses (Ibn Al-Athir) (VIII). In and around Aleppo, the earthquake is said to have been felt (Sibt Ibn Al-Jawzi) (V), and also in Antioch (V). This event was reported also in AlMousel (IV-V) and throughout the districts of Mesopotamia (IV), as far as Iraq, though without destruction of houses. Azarbaijan, Armenia, parts of Anatolia are said to have experienced the earthquake (Ibn Al-Athir; Sibt Ibn AlJawzi). The shock was felt throughout Egypt from Qus to Alexandria: in Cairo, the shock caused arousing sleepers who jumped from their beds in fear (V). Three violent shocks were reported, shaking buildings, doors and roofs (Abd Al-Latif). In Cyprus, the earthquake damaged churches and other buildings and was strongly felt (Abd Al-Latif; Annales 5689; Ibn Al-Athir) (VII?). The sea between Cyprus and the coast parted and mountainous waves were piled up, throwing ships up onto the land (Arabic authors). Eastern parts of the island were flooded and numbers of fish were left stranded (Abd AlLatif; Ibn Mankali in Taher). The earthquake is said to have been felt as far as Sicily (Ibn AlAthir) (IV) and Ceuta (Ibn Wasil) (III?). It is very likely that the shaking reported on or after 1 March 1202 felt in and around Constantinople 
was from the earthquake of 20 May (Nicetas) (IV). The loss of life caused by this earthquake and its aftershocks is high. A figure frequently quoted in Arab sources is 1100000 dead (AlDhahabi; Al-Suyuti) for the year 597-598 A.H. (1201-1202). This includes those dying of famine and the epidemic consequent on the failure of the Nile floods, graphically described by Abd Al-Latif, who noted 111000 deaths in Cairo along between 596 and 598 A.H. Aftershocks were reported from Hama, Damascus and Cairo, for at least four days (Abd Al-Latif).

$\langle 087\rangle 1212$ Antioch.

Seismological compilations

- Sieberg (1932): 1212, an earthquake in Antioch.

$\langle 088\rangle 1222$ Kelless.

Seismological compilations

- Sieberg (1932): 1222, there was a lava in Killis.

〈089〉 1236 Northern Syria: VI-VII.

Seismological compilations

- Sieberg (1932): 1236, an earthquake in Northern Syria, causing minor damage.

$\langle 090\rangle 1242$ Syria.

Seismological compilations

- Sieberg (1932): 1242, an earthquake was in Syria.

〈091〉 1254 Northern Syria.

Seismological compilations

- Sieberg (1932): 1254, an earthquake caused minor damage in Northern Syria.

$\langle 093\rangle 1274$ Syria.

Seismological compilations

- Sieberg (1932): 1274, an earthquake was in Syria.

〈094〉 1281 Syria.

Seismological compilations

- Sieberg (1932): 1281, a slight earthquake hit Syria, but without damage.

〈096〉 1290 Syria.

Seismological compilations

- Sieberg (1932): 1290, an earthquake was in Syria.
<097〉 1303 August 8 (It seems to be two different events). Cairo: VII; Alexandria: VII; Damanhur: VII; Safad: VII; Damascus: VI; Hama: VI; Antioch: IV; Tunis: IV; Barqa: IV; Morocco: IV; Cyprus: IV; Istanbul: IV; Sicily: IV. Tsunami, flood.

Parametric catalogues

- Plassard and Kogoj (1981): In 1303 August 8, $I=\mathrm{V}$, there was an earthquake causing destruction in Alexandaria with tsunami and Cairo. It was felt in Damascus (Abu Al-Fida; Al-Suyuti; Perrey).

Seismological compilations

- Al-Ghouneim (no date): In [702 A.H.] Zu-1Hijja 23 Thursday (1303 August 9) early morning, it was mentioned that a strong earthquake was in many towns and cities in Egypt. Many places in Cairo, Eskandariyeh, Damenhur were destroyed or fell down. It was felt in Barqa, Tunis, Sicily and Morocco. Cyprus was destroyed to the ground. It was felt in Antioch, Constantinople the great (Al-Dawadari). In this year [702 A.H.] of Zu-l-Hijja 23, a great earthquake in Egypt. In Cairo, many mosques, minarets and schools were destroyed. There was flooding of the Nile River with great sound. There was a sea wave in Eskandariyeh. A part of Safad citadel was collapsed and the sea in Akka was retread. Cracks appeared in the walls of Omyyad mosque at Damascus (Al-Maqrizi).

- Sieberg (1932): 1303, an earthquake in Syria. Part of walls of Hama was collapsed.

$\langle 099\rangle 1339$ January 13-February 11 Tripoli: VII; Palestine: IV.

Parametric catalogues

- Plassard and Kogoj (1981): 1339 JanuaryFebruary, $I=\mathrm{IX}$, an earthquake occurred causing destruction in Tripoli (Al-Suyuti).

Seismological compilations

- Al-Ghouneim (no date): In 739 A.H. Rajab (1339 January 13), an earthquake occurred at Tripoli, killing 60 persons.

- Sieberg (1932): 1338 July 20, an earthquake was in Syria. It was strong in Tripoli. It was felt in Palestine.

〈102〉 1399 September 20 Damascus: III-IV. Seismological compilations

- Al-Ghouneim (no date): In 802 A.H. Muhar- 
ram 17 (1399 September 20), a shock was felt at Damascus (Al-Asqalani).

$\langle 103\rangle 1403$ December 18 Aleppo: IV-V. Seismological compilations

- Ambraseys and Melville (1995): 1403 December 18 Tuesday, 806 A.H. Jamada II 3 Friday, a shock was felt in Aleppo and its dependencies, but without damage (Atsiz; Ibn Hajar).

〈104〉 1404 February 20 Qalaat Blatnes: VIII; Bkas: VIII; West of Aleppo: VII-VIII; Qalaat Al-Marqeb: VII-VIII; Tripoli district: VII; Lattakia: VII; Jableh: VII. Tsunami, landslide.

Parametric catalogues

- Ambraseys and Barazangi (1989): 1404 February $22,35.9 \mathrm{~N}-36.3 \mathrm{E}$, large.

- Plassard and Kogoj (1981): 1403-1404 December-January, in Lebanon $I=\mathrm{V}$, there was an earthquake which caused destruction in Aleppo with tsunami in the Syrian coast (Al-Suyuti; Perrey). - Poirier and Taher, 1980: 1404 February 11, $I_{0}=$ IX (MMS), heavy destruction in Aleppo, while Lattakia fortress was destroyed.

Seismological compilations

- Ambraseys and Melville (1995): 1404 February 20, 806 Sha'ban 8 , a damaging earthquake took place affecting the region west of Aleppo, where many places were destroyed. There was a long sequence of aftershocks which caused considerable concern, particularly to the west of Aleppo (Ibn Hajar; Ibn Al-Shihna). Other accounts mentioned that the most effects were experienced in the district of Tripoli, where many buildings were destroyed (Al-Jauhari). Either as a result of this shock, or of further strong aftershocks, part of the castle of Marqab collapsed at the beginning of Ramadan (mid March), together with other structures elsewhere (Al-Jauhari; Al-Maqrizi).

- Al-Ghouneim (no date): In 806 A.H. Sha'ban (from 1404 February 13), news received that a great earthquake was at Tripoli region, destroying many buildings including a part of Qalaat AlMarqab, Lattakia, Jableh, Blatnes citadel, Bkas and other towns in the mountain and the coastal areas, killing many people under the debris (AlMaqrzi). In this year [806 A.H.] Shaaban 8, a strong earthquake was in and around Aleppo, destroying many places. It was shacked on mid-day of Friday 3rd Jamada II. Many shocks were felt during this year (Al-Asqalani). In the latest third of Sha'ban, news brought from Tripoli region, that there was a great earthquake destroying many buildings and most parts of Qalaat Al-Marqab fell down (Al-Sayrafi).

- Sieberg (1932): 1402, an earthquake was in Syria, causing landslides with damage in a few cities. There were sea waves in the coastal area.

$\langle 105\rangle 1404$ November 5-December 4 Aleppo: V.

Parametric catalogues

- Poirier and Taher (1980): 807 A.H. Jamada I (1404 December 5), $I_{0}=$ VII (MMS), there were three shocks in Aleppo.

Seismological compilations

- Ambraseys and Melville (1995): 1404 November 7, 807 A.H. Jamada I 3 at midday, The shock was of long duration and was widely felt in other towns of the region. It caused great alarm, and was followed by a few aftershocks, but no damage was reported (Al-Suyuti; Ibn Hajar).

- Al-Ghouneim (no date): 807 A.H. Jamada I (from 5 November 1404), a great earthquake in Aleppo, causing a large panic without damage (Al-Asqalani).

- Sieberg (1932): 1404, an earthquake in Syria.

〈106〉 1407 April 9-May 8 Antioch: VII; Cyprus: V. Surface faulting.

Parametric catalogues

- Plassard and Kogoj (1981): 1407 April-May, $I=I V$, there was an earthquake that caused destruction in Antoich (Al-Suyuti).

- Ambraseys and Barazangi (1989): 1407 April $29,35.7 \mathrm{~N}-36.3 \mathrm{E}, M_{s}=7.0$, faulting.

Seismological compilations

- Ambraseys and Melville (1995): 1407 April, 809 A.H. Zu-L-Qa'da, a shock was in Antioch, killing 100 people or more (Al-Suyuti; Ibn Hajar). An earthquake felt strongly throughout Cyprus on 29 April 1407 may be the same event. - Al-Ghouneim (no date): In 809 A.H. Zu-l-Qa'da (from 1407 April 09), a great earthquake was at Antioch, killing a large number of people, 100 or more, under the debris (Al-Asqalani).

〈107〉 1408 December 29 Shugr: VIII-IX; Bkas: VIII-IX; Blatnes: VIII; Lattakia: VII; 
Jableh: VII; Antioch: VII; Syrian coast: VI (fig. 17). Faulting between Sfuhen and AlQuseir. Landslide in Sfuhen. Tsunami in Lattakia.

Parametric catalogues

- Plassard and Kogoj (1981): 1408-1409 December-January, in Lebanon $I=I X$. They are earthquakes which caused destruction in Tripoli and Aleppo (Al-Suyuti).

- Poirier and Taher (1980): 1408 December 30, $I_{0}=$ X-XI (MMS), heavy destruction was in Antioch and Aleppo, the ice fell off the top of Jabal Al-Akraa. Between Al-Qucir and Saltuhum, a fissure 1 mile long appeared. A sea wave in Lattakia.

Seismological compilations

- Ambraseys and Melville (1995): 1408 Decem- ber 29, 811 A.H. Sha'ban 10, there was a great earthquake in Shugr and Antioch, where Shugr and its region were destroyed (Atsiz). A great earthquake affected the districts belonging to Aleppo and Tripoli, and destroyed a number of places in Lattakia, Jableh and Balatunus. The castle of Balatunus collapsed and 15 people were killed. 15 people were killed in Jableh. Shugr Bakas was totally destroyed with its castle, and all but 50 of its inhabitants were killed. The ground fissured and was thrown down over the distance of a stage, from the town of Qusair to Salt(f)uham (?) - a town on the top of a mountain - about a mile of which moved during the night, carrying with it trees, buildings and their inhabitants, who were unaware of what was happening. The shock also affected Cyprus, where many

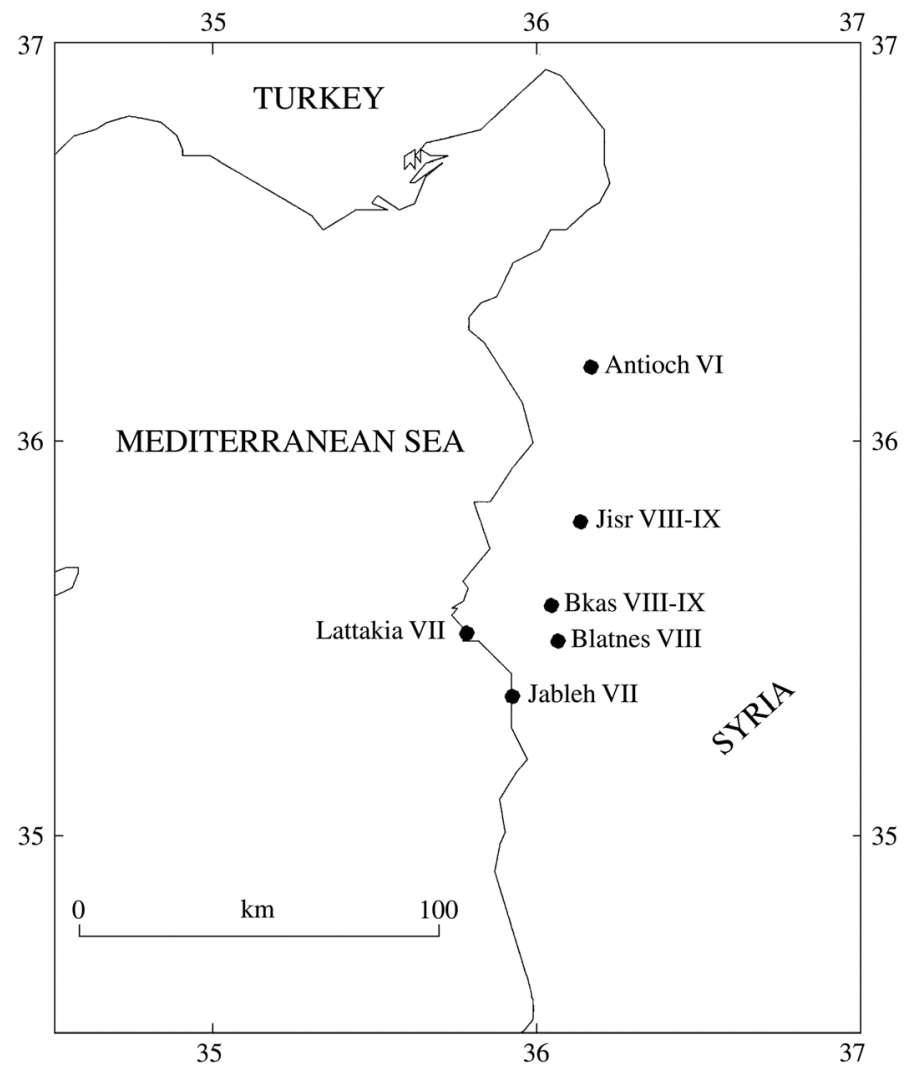

Fig. 17. Map of intensity distribution for December 29, 1408 earthquake. 
places were destroyed in the mountains and the plains. Snow was seen on the top of Jabal AlAkraa, and the sea receded for 10 farsakhs ( ca. 60 $\mathrm{km}$ ) and then returned. Ships at sea touched the bottom before the water returned to normal, without hurting anyone (Ibn Hajar). According to Ambraesys' point of view, the available evidence suggests that surface faulting extended for a distance of at least $20 \mathrm{~km}$ from Qusair, either southwest in the direction of the coast, or south along one or more strands of the Dead Sea Fault.

- Al-Ghouneim (no date): In 811 A.H. Sha'ban 10 (1408 December 30), a great earthquake in Aleppo, Tripoli and their vicinity. Many places in Lattakia, Jableh and Blatnes were destroyed. Fortress of Platnes fell down, killing 15 persons under the debris. In Jableh, 15 persons were killed. Both citadels of Bkas totally collapsed and all their residents were killed and only 50 persons survived. The earth was opened between Salfouhum and Al-Qusair. Salfouhum moved from the top of the hill down along one mile with its inhabitants, trees, springs and animals, but without damage. In Cyprus, many places were destroyed. It was felt in the coastal area of Syria. The ice masses on the Jabal AlAqra were seen moving down. In the sea, sailors mentioned that the sea retreated then returned back without any damage (Al-Maqrizi).

〈108〉 1484 March 29-April 27 Aleppo: V-VI. Seismological compilations

- Al-Ghouneim (no date): In 889 A.H. Rabi I (started from 148429 March), Aleppo was shaken by 6 strong shocks (Al-Suyuti).

〈109〉 1491 April 24 Nicosia: VII; Limassol: VII; Famagusta: VII; Paphos: VII; Damascus: IV; Cairo: IV; Crete: IV.

Seismological compilations

- Ambraseys et al. (1994): 1491 April 24, two slight shocks a week apart were reported from Damascus, Cairo and Crete, both earthquakes caused heavy damage in Cyprus, where the forts at Limassol, Paphos and Famagusta and buildings in Nicosia were destroyed (Anonymous Pilgrim; Archivo Ducale Sforzesco-Milan; BenMenahem; Darrouzes; Dietrich von Schachtem). In Damascus, the first shock, which was not widely felt, occurred after the sunset prayers on
16 Jumada II-evening of 25 April; the second was before sunrise on 22 Jumada II-1 May (Ibn Tulun). In Egypt, the earthquake was alarming, shaking buildings and lasting a daraja or more ('Abd Al-Basit; Al-Sakhawi). The second shock was slight (Al-Suyuti; Ibn Iyas).

〈112〉 1546 September 29 Nablus: VI-VII; Damascus: V; Al-Quds: VI; Yafa: VI; Tripoli: VI; Famagusta: V. Tsunami at Cyprus.

Parametric catalogues

- Plassard and Kogoj (1981): 1546 September 29, $I=\mathrm{VI}$, there was an earthquake which caused destruction in Nablus, it was strong in Damascus and Famagusta in Cyprus (Perrey; Sieberg). There was a tsunami in Cyprus (Shalem Nathan).

Seismological compilations

- Sieberg (1932): 1546 September 29, a strong earthquake was in Samaria, causing heavy damages in Nablus. Damages were recorded in Jerusalem, Yafa, Tripoli, Damascus and Famagusta. It was accompanied with a sea wave.

$\langle 115\rangle 1568$ October 10 Lattakia: VII; Famagusta: V; Limassol: IV; Nicosia: IV.

Seismological compilation

- Ambraseys and Finkel (1995): An order from the Kadi of Lazkiya (Lattakia), dated 18 Rebi-II A.H. (10 October 1568), says that 'The great earthquake ruined the walls and roofs of many mescids (mosques), mihrabs and imarats in the town and villages; in particular, some walls of the great old mosque built by Sultan Alaeddin are demolished and some walls are cracked (BBA). Limassol and Nicosia were affected by some shocks of varying intensity, Famagusta was also shaken for eight days and many people moved out and camped in the countryside (Lusignano). This earthquake seems probable in Lattakia associated with the fore- and aftershock activity of the same event, a possible location of which would be between the Syrian coast and Cyprus.

〈116〉 1577 Northern Syria: VI-VII; Palestine: IV; Cyprus: IV; Armenia: IV. Aftershocks.

Parametric catalogues

- Plassard and Kogoj (1981): 1577, I= IV, there was an earthquake that caused a destruction in Northern Syria and Cyprus. It was felt in Palestine (Perrey; Sieberg). 
Seismological compilations

- Sieberg (1932): 1577, a destructive earthquake was in Northern Syria. It was felt in Palestine and Armenia. Aftershocks lasted four months.

\section{$\langle 120\rangle 1616$ July 22 Aleppo: VI.}

Seismological compilations

- Ambraseys and Finkel (1995): 1616 July 22, a strong earthquake was experienced on the feast of S. Maria della Neve by Pietro della Valle while he was in Aleppo. The shock did not last long and caused no damage in the town (Valle).

- Sieberg (1932): 1616 August 27, a destructive earthquake in Aleppo collapsed its walls.

$\langle 126\rangle 1640$ Damascus: VI; Syria; Tabriz.

Parametric catalogues

- Plassard and Kogoj (1981): 1640, I= VI, it was an earthquake that caused destruction in Damascus (Perrey ?).

Seismological compilations

- Sieberg (1932): 1640, an earthquake was in Syria. Some buildings in Damascus fell down. It was felt in Tabriz.

$\langle 127\rangle 1656$ February Tripoli: VII; Palestine: IV. Parametric catalogues

- Plassard and Kogoj (1981): 1656 February, in Lebanon $I=$ VII, an earthquake occurred in Tripoli, causing some damages (Perrey; Willis). - Ben-Menahem (1979): 1656 February, 34.9N, $36.2 \mathrm{E}, I_{0}=\mathrm{X}, M_{l}=7.0$, destruction of Tripoli. It was felt in Palestine (Al-Sinawi and Ghaleb; Amiran; Plassard and Kogoj; Sieberg; Willis).

Seismological compilations

- Sieberg (1932): 1656 February, an earthquake in Syria ruined half of Tripoli. It was felt in Palestine. Shocks repeated in November.

$\langle 128\rangle 1657$ Aleppo: IV.

Seismological compilations

- Ambraseys and Finkel (1995): 1657, during this year four earthquakes were felt in Aleppo within a period of two months (Besson).

〈129〉 1666 September 22 Al-Mousel: VIIVIII; Sinjar: VI-VII; Sharqat: VI-VII; Aleppo: V; Tabriz: V; Van: V. Landslides, aftershocks.

Parametric catalogues
- Ambraseys (1989): 1666 September 22, 37.0

$\mathrm{N}-43.0 \mathrm{E}, M_{s}=6.6, I_{\max }(\mathrm{MSK})=\mathrm{IX}$.

Seismological compilations

- Ambraseys (1989): 1666 September 22, news of the disaster was reported from Aleppo where the shock was apparently felt. In Al-Mousel and its surroundings the shock was particularly strong. Many houses were destroyed in AlMousel and also the cathedral that housed the tomb of Nebi Yunus. Monasteries to the north of the town were ruined. In addition, 5 towns and 45 villages were totally destroyed, and damages extended to Sinjar and Sharqat. It is said that as a result of the earthquake «four great mountains were raised up from the ground and thrust against each other reducing themselves into dust», an allusion, perhaps, to landslides. Destructive shocks continued for several days. It appears that the earthquake was felt strongly in Van and Tabriz (Fiey; Hammer; Theatrum Europeum).

- Sieberg (1932): 1666, Aleppo and 44 places affected deeply by an earthquake.

〈130〉 1680 March 22-23 Aleppo: IV.

Seismological compilations

- Ambraseys and Finkel (1995): Slight shocks on 22 and 23 March 1680 were felt by a European traveler in Aleppo (d'Arvieux).

$\langle 132\rangle$ 1693-94 Northwestern Iraq. Landslides. Seismological compilations

- Ambraseys and Finkel (1995): In 1105 A.H. (2 September 1693-21 August 1694) in the region of Jabal Sinjar in NW Iraq, there was a mighty noise which heard and an area 50 cubits long by 30 wide sank down beneath the mountain (Al'Umari). It is note necessary to be assumed that an earthquake was responsible for triggering what appears to be landslide or rock-fall.

\section{$\langle 133\rangle 1701$ Aleppo: IV.}

Seismological compilations

- Ambraseys and Finkel (1995): 1701, it seems that an earthquake was felt in Aleppo during this year (Panzac).

\section{〈136〉 1719 March Aleppo: VII.}

Parametric catalogues

- Plassard and Kogoj (1981): 1719 March, $I=I V$, it was an earthquake that caused destruc- 
tion in Aleppo, 200 houses of Aleppo affected (Sieberg).

Seismological compilations

- Ambraseys and Finkel (1995): An earthquake shook Aleppo during this month, damaging three mosques and ruining more than 200 houses (Berryat).

- Sieberg (1932): 1719 March, a destructive earthquake in Syria caused destruction of three mosques and 200 houses in Aleppo.

\section{$\langle 137\rangle$ 1722-1723 Aleppo: VII.}

Seismological compilations

- Ambraseys and Finkel (1995): A nearcontemporary source says that: in 1135 A.H. (1722-1723) Aleppo was afflicted by a terrible earthquake, which destroyed most of its houses and killed many people (Al-Ghazi). Modern author (Panzac) repeated this information.

〈138〉 1726 April 15 Jum: > VII; Aleppo: VII; Iskenderun: IV; Famagusta: III.

Seismological compilations

- Ambraseys and Finkel (1995): 1726 April 15, this earthquake occurred at quarter past noon and caused considerable damage in the region of Jum, particularly at Harim, but details are lacking (ANF; Panzac). It was violent in Aleppo, where some walls were thrown down, and caused panic in Iskenderun $(\mathrm{PMdF})$. It was perceptible in Famagusta at the same hour, but there is no evidence in French consular correspondence that it was felt in Antioch (ANF).

- Sieberg (1932): 1726 April 15, three shocks caused collapsing the old walls of Aleppo. News brought that an earthquake occurred in Iskandaroun.

〈139〉 1738 September 25 Iskenderun: VIII; Bellen Bass: VII-VIII; Antioch: VII; Jabal Al-Amanus: VII; Aleppo: V-VI; Kelless: V; Bereket: V.

Seismological compilations

- Ambraseys and Finkel (1995): 1738 September 25 , this earthquake caused considerable damage in the region of Amanus, ruining a number of villages on the east side of the Belen Bass (Riggs). Part of Antioch's walls and some houses collapsed according to European traveler (Pococke). A part of castle between Bayas and Iskenderun has been demolished (BBA). Probably, it was demolished by this earthquake. The shock, according to an eyewitness, was strongly felt in Aleppo without damage (Kort). This is certainly the same event that was also felt in Kilis (Kilisli Kadri) and in other parts of the region of Bereket (Riggs).

- Sieberg (1932): 1737, a destructive earthquake in Antioch destroyed completely many old ruins.

$\langle 140\rangle 1752$ July 21 Lattakia: VII; Tripoli: V. Tsunami at the Syrian coast.

Parametric catalogues

- Plassard and Kogoj (1981): 1752 July 21, in Lebanon $I=$ VII, a strong earthquake occurred in Tripoli, Lattakia and along the entire Syrian coast, generating a tsunami (Sieberg; Willis).

- Ben-Menahem (1979): 1752 July 21, off coast Lattakia, $I_{0}=\mathrm{X}, M_{l}=7.0$, destruction at Tripoli and Lattakia. Tsunami at Syrian coasts (Amiran; Plassard and Kogoj; Sieberg; Willis ).

Seismological compilations

- Sieberg (1932): 1752 July 21, an earthquake occurred in the Syrian coast, generating a destructive sea wave. Great damage was in Lattakia. It was felt in Tripoli. It was said that there were 20000 deaths.

〈141〉 1759 February 17 Aleppo: V.

Seismological compilations

- Sieberg (1932): 1759 February 17, a strong earthquake occurred in Aleppo.

$\langle 142\rangle 1759$ June 10 Aleppo: IV.

Seismological compilations

- Ambraseys and Finkel (1995): 1759 June 10, an eyewitness reports that a slight earthquake was felt in and around Aleppo in the morning (Russell).

- Sieberg (1932): 1759 June 10, a weak shock was felt in Aleppo.

$\langle 143\rangle 1759$ October 30, 03:45 (local time) AlQunaytra: VIII; Safad: VII; Acre: VI; AnNasra: VI; Sidon: VI; Saasaa: VI; Damascus: V; Aleppo: IV; Al-Quds: IV; Beirut: IV; Antioch: IV; Gaza: IV; Cyprus: IV. Landslides at the west of Damascus and Tabariya. Tsunami at Acre and Tripoli. Aftershocks.

Parametric catalogues

- Plassard and Kogoj (1981): 1759 October 30, 
$I=$ VIII (in Lebanon), it was an earthquake that caused destruction in Safad and large damage in Al-Chouf (Jalfaq).

- Ben-Menahem (1979): 1759, October 30, 02 h, $33.0 \mathrm{~N}, 35.5 \mathrm{E}, I_{0}=\mathrm{IX}, M_{l}=6.5$, heavy destruction and many casualties in Safad. Tiberias city wall overthrown. Area of damage extend to Damascus. Tsunami in the sea of Galilee. Damage in Sidon MM=VII (Amiran; Barslawy; Plassard and Kogoj; Sieberg; Willis).

Seismological compilations

- Sieberg (1932): 1759 October, a set of shocks started for three months in ... and Bekaa Valley. It was said that 30000 persons were killed due to these events, from which 20000 deaths in Bekaa.

\section{Monographs}

- Ambraseys and Barazangi (1989): 1759 October $30,33.1 \mathrm{~N}-35.6 \mathrm{E}, M_{s}=6.6$. This earthquake is considered as a foreshock of the main event of November 25. It was affected the region of Safad and a mountain area to the NE where many villages were destroyed with the loss of about 2000 lives. Safad and Qunaitra were almost totally ruined, and many of the inhabitants were killed. In Sidon, Saasaa, Nazareth and Acre, few houses collapsed without casualties. In and around Damascus, this earthquake caused considerable concern and widespread minor damage, one or two houses collapsed, a few were damaged, many were cracked, many public buildings such as minarets and tall buildings were damaged, the water supply of Damascus was affected by rock falls. In Tiberias, a landslide took place but without loss of life. Antioch, Aleppo, Jerusalem and Gaza were felt, and it was reported by sailing boats between Cyprus and Beirut. In Acre and Tripoli, there was a seismic sea wave that flooded them without damage. This earthquake was followed by a series of strong aftershocks, some of which were felt as far as Aleppo, that added to the damage (Al-Budayri; ANF; Archives British Legations; Archives Historiques Ch. Comm. Marseille; Ben Zvi; Dahman; Findikli; Vitaliano; Yaari).

$\langle 145\rangle 1760$ January Qadicha: V; Aleppo: VI. Earthquake.

Parametric catalogues

- Plassard and Kogoj (1981): 1760 January, I= = VII (in Lebanon), a strong earthquake occurred in Qadicha (Deir-Marjerjius and Qanobin), it was stronger in Aleppo (Perrey; Sieberg).

Seismological compilations

- Sieberg (1932): 1760 January, aftershocks continued to occur, destroying Deir-Marjerjius. It was felt in the mountain of Lebanon.

\section{〈146〉 1765 Tripoli: V; Aleppo: IV.}

Parametric catalogues

- Plassard and Kogoj (1932): 1764 February 14, $19 \mathrm{~h}, I=$ VI (in Lebanon), a strong earthquake hit Tripoli. It lasted 6 seconds (Perrey). Seismological compilations - Ambraseys and Finkel (1995): 1765, during the year there were earthquakes in the region between Aleppo and Tripoli (Lemmens).

- Sieberg (1932): 1764 January/February, a shock was in Aleppo. In 1764 February 14, a strong shock was in Syria. It was felt in Tripoli.

$\langle 147\rangle 1778$ May 5 Aleppo: IV.

Seismological compilations

- Ambraseys and Finkel (1995): 1778 May, at 5

h $10 \mathrm{~min}$ there was an earthquake in Aleppo without damage (PGF).

- Sieberg (1932): 1778 May 5, a shock was felt in Aleppo.

〈148〉 1779 June 8 Aleppo: V-VI.

Seismological compilations

- Ambraseys and Finkel (1995): 1779 June 8, preceded by an earthquake at the beginning of the month, a strong earthquake occurred in Aleppo on June, causing considerable concern (BRG). Another eyewitness reports the same event on Tuesday, 10 June, between $23 \mathrm{~h}$ and midnight, stating that it caused no damage save the collapse of inhabited houses (Evens). 8 June fell on Tuesday.

\section{〈149〉 1783 December 14 Aleppo: VI; Tripo-} li: IV.

Parametric catalogues

- Plassard and Kogoj (1981): 1783 July 20, I= IV (in Lebanon), an earthquake felt in Tripoli and Aleppo (Sieberg).

Seismological compilations

- Ambraseys and Finkel (1995): 1783 December 14, a strong shock was felt in Aleppo (BV; Guys; Volney). 
- Sieberg (1932): 1783 July 20, an earthquake occurred in Northern Syria. In Aleppo, there was minor damage. It was felt in Tripoli and the whole of Lebanon.

$\langle 150\rangle 1783$ December 4 Aleppo: IV.

Seismological compilations

- Sieberg (1932): 1783 December 4, a slight shock occurred in Aleppo.

\section{〈151〉 1795 January Aleppo: VI.}

Seismological compilations

- Ambraseys and Finkel (1995): 1783 December, at $14 \mathrm{~h} 10 \mathrm{~min}$, two shocks in Aleppo, the second being strong enough to damage many houses (Olivier).

- Sieberg (1932): 1795 January, two shocks caused some damages in houses at Aleppo.

〈152〉 1796 April 26 Qalaat Al-Marqeb: VIII; Al-Qadmous: VIII; villages along Nahr Al-Kabir: VII-VIII; Jableh: VII-VIII; Bkas area: VII-VIII; Lattakia: VII; Saida: V; Aleppo: IV; Tripoli: V. Landslides, liquefaction.

Parametric catalogues

- Plassard and Kogoj (1981): 1796 May 5, I= V (in Lebanon), an earthquake caused destruction in Lattakia, where one-third of the city houses were destroyed (Blanckenhorn; Sieberg; Willis). - Ambraseys and Barazangi (1989): 1796 April $26,35.7 \mathrm{~N}-36.0 \mathrm{E}, M_{s}=6.6$.

- Ambraseys (1989): 1796 April 26, 09:05 (LT), $35.5 \mathrm{~N}-36.0 \mathrm{E}, M_{s}=6.6, I_{\max }(\mathrm{MSK})=\mathrm{VIII}$.

Seismological compilations

- Ambraseys and Finkel (1995): 1796 April 26, this was a destructive shock in the Sahel region of Lattakia on the Syrian littoral (Ambraseys, 1989). The earthquake occurred on 18 Shawal 1210 A.H. (Nuri). At about $9 \mathrm{~h}$ (Olivier) without foreshocks and lasted with intermissions for about one minute. In Lattakia so violent that almost everything collapsed with the first shock. The traveler Olivier, who had been there 22 months earlier, found the town barely recognizable. In the port area the old fort at the entrance of the harbor (Morana) and the tobacco stores of the customshouse and the han (BBA), solidly-built structures, collapsed instantly killing the Aga, his officers, 400 people and many animals (AMAE CADN).
Out of a population of about 5000, 1500 (Olivier)2000 (Guys) people were killed and many injured. One-third of the houses was destroyed and the remainder more or less ruined. Damages were equally heavy in Jableh where most of the houses were destroyed and the minaret of the mosque of Ibrahim fell: farmers lost their lives in surrounding villages; the castles of Markab and Qadmus were completely ruined (Nuri). There was also loss of life in the Bucak area north of Lattakia and settlements along the Nahr Al-Kebir River suffered in particular (ANF). The shock was felt between Aleppo and Tripoli and in Saida (Sidon) (Browne). It is said that as a result of the earthquake the surface of the ground around Lattakia rose (Olivier) but this may be an exaggeration.

- Ambraseys (1989): 1796 April 26 morning, a destructive earthquake occurred in the Sahel district of Lattakia. It lasted for about $1 \mathrm{~min}$, almost totally ruining the coastal plain between Jableh and Bucak. Most of the houses collapsed in Jableh, and water wells caved in and became dry. Most of the miri villages in the Nahr Al-Kebir plain were ruined. In Lattakia, 1500 out of a population of 5000 were killed. One-third of Lattakia collapsed and the remainder was damaged. The old castle, minarets, watchtowers and large buildings fell down. In the port area, the tobacco customs-house fell in and killed 400 people. It is said that the shock raised the surface of the ground several toises. It was strongly felt at Saida. Aftershocks continued to be felt for two months (Consular Archives; Cevdet; Olivier, 1807).

- Sieberg (1932): 1796 April 26 or May 5, a destructive earthquake was in Northern Syria. 1/3 of the houses in Lattakia was destroyed and there were 1500 victims. In 1796 June, many weak shocks were felt in Lattakia.

\section{〈153 1802 Baalbak: VI; Palestine: III.}

Parametric catalogues

- Ben-Menahem (1979): 1802, 34.0N, 36.2E, $I_{0}=$ VIII-IX, $M_{l}=6.2$, great damage at Baalbak . It was felt in Palestine (Amiran; Karnik; Plassard and Kogoj; Seiberg).

Seismological compilations

- Sieberg (1932): 1802, a vast earthquake occurred in Central Syria. Minor damage occurred in Al-Bekaa and Baalbak. It was felt in Palestine. 
$\langle 155\rangle 1814$ Al-Laja: VI-VII. Rock-falls. Seismological compilations

- Sieberg (1932): 1814, there was a strong earthquake at the edge of the volcanic area in Al-Laja. It was accompanied by large rock-falls.

〈156〉 1819 February Syria: IV-V.

Seismological compilations

- Sieberg (1932): 1819 end of February, a strong shock was felt in Syria.

\section{$\langle 158\rangle 1822$ September 5 Aleppo: VII.}

Parametric catalogues

- Poirier and Taher (1980): 1822 September 5, destruction of what remained in Aleppo, with 20000 victims.

$\langle 159\rangle 1830$ Aleppo: III.

Seismological compilations

- Sieberg (1932): 1830, a shock was felt in Aleppo.

$\langle 160\rangle 1831$ February 22 Aleppo: V.

Seismological compilations

- Sieberg (1932): 1831 February 22, a very strong shock was felt in Aleppo.

〈162〉 1844 September 19 and 30 Aleppo: V. Seismological compilations

- Sieberg (1932): 1844 September 19 and 30, strong shocks were felt in Aleppo.

〈164〉 1846 December 3 Aleppo: V.

Seismological compilations

- Sieberg (1932): 1846 December 3, there was a strong shock in Aleppo.

\section{$\langle 165\rangle 1850$ February 12 Beirut: III; Ain} Hamadeh: III.

Parametric catalogues

- Plassard and Kogoj (1981): 1850 February $12, I=$ III (in Lebanon), an earthquake was felt in Beirut and Ain Hamadeh (Sieberg).

Seismological compilations

- Sieberg (1932): 1850 February 12, a slight shock was in Beirut. It was felt in Ain Hamadeh.

〈166〉 1854 Antioch: III; Suaidiya: III; Beirut: III; Aleppo: III; Yafa: III.
Parametric catalogues

- Plassard and Kogoj (1981): 1854, I= III (in Lebanon), an earthquake was felt in Beirut, Aleppo and Yafa (Blackenhorn; Willis).

Seismological compilations

- Sieberg (1932): 1854, an earthquake was felt in Syria. It was felt in Swedieh, Antioch, Aleppo, Beirut and Yafa.

〈167〉 1859 January 24 Tripoli: III; Beirut: III; Damascus: III; Aleppo: III.

Parametric catalogues

- Plassard and Kogoj (1981): 1859 January 24, $I=I V$, an earthquake was felt in Tripoli, Beirut, Damascus and Aleppo (Blachenhorn; Sieberg; Willis).

Seismological compilations

- Sieberg (1932): 1859 January 24, three shocks were felt in Damascus and Tripoli.

〈168〉 1864 August 15 Aleppo: IV.

Seismological compilations

- Sieberg (1932): 1864 August 15, a strong shock was felt in Aleppo.

$\langle 169\rangle 1868$ April 16 Aleppo: III.

Seismological compilations

- Sieberg (1932): 1868 April 16, a shock was felt in Aleppo.

$\langle 170\rangle 1870$ January 2 Aleppo: III.

Seismological compilations

- Sieberg (1932): 1870 January 2, a shock was felt in Aleppo.

〈171) 1872 April 3 Harem: VIII; Armanaz: VIII; Buhyret Al-Amq: VII-VIII; Antioch: VII-VIII; Aleppo: VII; Suaidiya: VII; Izaz: VI-VII; Idleb: VI-VII; Iskenderun: VI-VII; Hama: IV; Homs: IV; Tripoli: IV; Damascus: III; Beirut: III; Sidon: III; Diyar Bakr: III; Egypt: III; Rhodos: III (figs. 18 and 19). Faulting at Baghras. Liquefaction, tsunami, aftershocks.

Parametric catalogues

- Ambraseys (1989): 1872 April3, 07:40 (LT), $36.4 \mathrm{~N}-36.5 \mathrm{E}, M_{s}=7.2, I_{0}(\mathrm{MSK})=\mathrm{X}$.

- Ambraseys and Barazangi (1989): 1872 April 3, 36.4N, 36.5E, $M_{s}=7.2$.

- Plassard and Kogoj (1981): In Lebanon I=IV, 


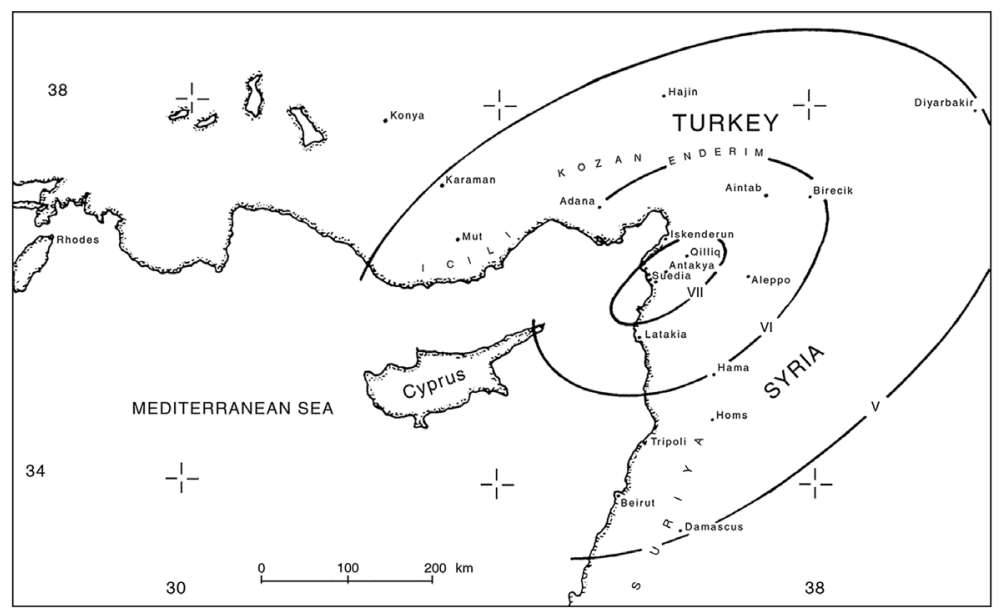

Fig. 18. Map of intensity distribution for April 3, 1872 earthquake (Ambraseys, 1989).

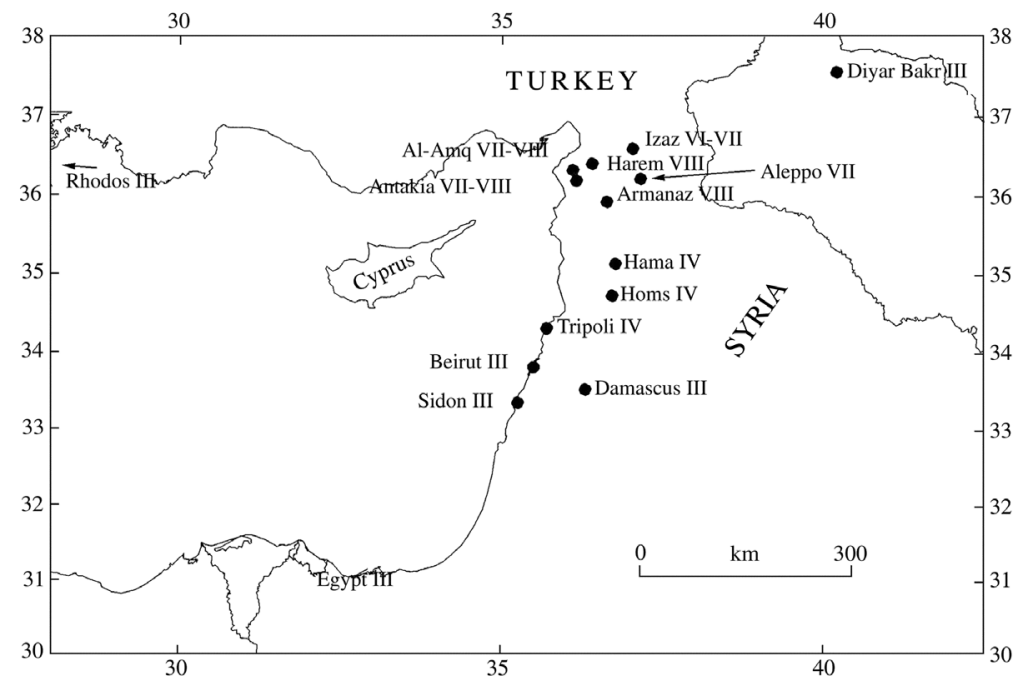

Fig. 19. Map of intensity distribution for April 3, 1872 earthquake.

at $07 \mathrm{~h} 50 \mathrm{~min}$ an earthquake caused destruction in Antioch and Swedieh, it was felt in Beirut and Tripoli (Fuchs, 1886). In April 28, an earthquake was felt in Sidon, Beirut and Antioch (Diaire des Pères Jésuites de Saida; Journaux Contemporains des Événments).
- Poirier and Taher (1980): 1872 April 2, Antioch was destroyed at 30\%, 500-1800 victims. - Ben-Menahem (1979): 1872 April 2, 07 h 45 $\min , 36.2 \mathrm{~N}, 36.2 \mathrm{E}$, near Samandag, $I_{0}=\mathrm{X}-\mathrm{XI}$, $M_{l}=7.3$, destruction of Antioch. Felt in Palestine and Egypt. Strong aftershocks on April 10 
and May 15 (Amiran; Ergin et al.; Karnik; Plassard and Kogoj; Sieberg).

\section{Seismological compilations}

- Ambraseys (1989): 1872 April 3, a large earthquake occurred at 7:40 a.m., affecting the reaches of the Orontes where the river empties into the Mediterranean. The shock almost totally destroyed Antioch as well as its seaport of Suaidiya. At Antioch, the shock lasted $40 \mathrm{~s}$, killing 500 people and injuring an equal number. 1960 houses of 3003 were totally destroyed and 894 so damaged. There were a further 1331 other buildings, i.e. shops, mosques, churches, etc., of which there remained 349 shops, one mosque and one soap factory; thus, of the 4334 buildings of all kinds, only 500 were left standing. The Greek cathedral, completed before the earthquake, and the American Protestant church and premised collapsed, killing four members of the community. The East and North gates (of Bab Bulus) were thrown down and part of the citadel walls collapsed. The old Roman bridge of four arches was breached in several places and all manor houses, including that of the Scotsman Yate, were destroyed. By contrast with the lower part of the town, the upper part suffered less severely. Thirty-eight villages between Suaidiya and Beilan were totally destroyed. 2150 houses were destroyed in Suaidya, and more than 300 people killed or seriously injured. The nearby villages of Kabusi, Jedida and Laushiya were razed to the ground with loss of life. The sea rose after the earthquake, allegedly to a great height, flooding the coast. Qaramut and its district were completely destroyed. In the town itself there were 170 dead and 187 wounded; in addition to shops and public buildings, 3552 houses were razed to the ground. Heavy damage extended to east of Amik Glü. Qilliq was totally ruined with the loss of 300 lives, and neighboring villages suffered similarly. Here, it is said, the earthquake split the ground in places and yellow sand filled the area, a description suggesting widespread liquefaction. Also, between Batrakan and Quaralu, the valley to the east of hills is said to have dropped as a result of the earthquake and the ground was 'rent' all the way to Baghras, an allusion to faulting. Damage was very heavy and there was great loss of life to the north and south of Qilliq, particularly in the region of Harim and Armanaz, but details are lacking. In Aleppo, the shock lasted 72 $\mathrm{s}$ and caused great panic. About 100 houses were badly damaged or collapsed, killing 7 and injuring 3 people. Part of the citadel fell down. Damage extended to Izaz, Basut, Zirbeh and Idleb as well as to settlements along the Mediterranean coast such as Arsuz and Iskenderun. Damage to the south of Afsiyeh became known many months after the earthquake, as did damage to bridges and hans. The Orontes bridge at Jisr AlHadid was damaged and its defense towers were thrown down. The shock was very strongly felt at Adana, Aintab, Birecik, Hama, Homs and Tripoli. It was reported from Rhodes, Konya, Diyar Bakr, Beirut and Damascus. The earthquake was not felt in Egypt as alleged by modern writers. Aftershocks continued to be felt with decreasing severity throughout April and May, but did not cease altogether until 1873 February (Consular Archives; Press Reports).

- Sieberg (1932): 1872, a destructive earthquake in Northern Syria, killing 1800 persons. 2/3 of Antioch and Swedieh were ruined and rebuilt again using stones of the ramparts of the city. Iskandarun and Aleppo felt by this event, but without damage. It was felt in Urfa, Diyar Bakir, many places in Mesopotamia, Damascus, Yafa, Egypt, Tripoli (of Libya), Rhodos and Smyrna. Aftershocks lasted till August, that were felt in Antioch, Aleppo and Smyrna.

\section{$\langle 172\rangle 1873$ February 9 Aleppo: III.}

Seismological compilations

- Sieberg (1932): 1873 February 9, a shock was felt in Aleppo.

〈173〉 1873 February 14 Tyr: V; Beirut: III; Al-Quds: III; Akka: III.

Parametric catalogues

- Plassard and Kogoj (1981): 1873 February 14, in Lebanon $I=\mathrm{V}$, an earthquake felt in Tyr, Beirut and Palestine (Fuchs; Sieberg).

- Ben-Menahem (1979): 1873 February 14, off coast Sur, $M_{l}=6.2$, strong at Sur. Felt in Jerusalem and Cairo (Amiran; Plassard and Kogoj; Sieberg).

Seismological compilations

- Sieberg (1932): 1873 February 14, a strong shock was reported in Tyre. It was felt in Beirut, Akka and Jerusalem. 
$\langle 177\rangle 1884$ June 6 Aleppo: V.

Seismological compilations

- Sieberg (1932): 1884 June 6, a strong shock was felt in Aleppo.

$\langle 178\rangle 1896$ February 20 Damascus: V.

Parametric catalogues

- Plassard and Kogoj (1981): 1896 February 20, I= III? (in Lebanon), an earthquake caused damage in Damascus (Sieberg).

Seismological compilations

- Sieberg (1932): 1896 February 20, a slight earthquake occurred in Damascus. It was followed by a shock at night.

〈179〉 1896 May 12 Baalbak: V.

Parametric catalogues

- Plassard and Kogoj (1981): 1896 May 12, $I=\mathrm{VI}$, two shocks were felt at Baalbek (Sieberg). Seismological compilations

- Sieberg (1932): 1896 May 12, two strong shocks were felt in Baalbak. The second was stronger.

〈180〉 1896 May 14 Antioch: V; Jisr Ash'Shoughur: III; Lattakia: III; Aleppo: III; Kelless: III.

Seismological compilations

- Sieberg (1932): 1894 May 14, an earthquake occurred in Northern Syria. It was strong in Antioch. It was weak in Jisr Ash'Shoughur, Lattakia, Aleppo and Kelless.

〈181〉 1896 June 29 Syria: IV; Bisri: IV; Shouf: IV; Palestine: IV; Cairo: IV.

Parametric catalogues

- Plassard and Kogoj (1981): 1896 Jun. 29, $I=\mathrm{VI}$, an earthquake was felt at Bisri, Chouf in Lebanon, Syria, Palestine and Cairo (Blanckenhorn, 1905; Willis, 1928, 1933a,b; Sieberg, 1932).

Seismological compilations

- Sieberg (1932): 1896 June 29, an earthquake caused heavy destruction at Lymasol.

\subsection{Historical seismic events without re-evaluation}

〈092〉 1268 Kilikia.

Parametric catalogues

- Plassard and Kogoj (1932): 1268, I= III, an earthquake caused destruction in Cilicia (Abu Al-Faraj; Al-Suyuti).

〈101〉 1355 Syria; Armenia; Palestine.

Seismological compilations

- Sieberg (1932): 1355, an earthquake in Syria caused minor damage. It was felt in Armenia and Palestine.

〈144) 1759 November 25, 19:23 (local time) Baalbak: > VIII; Serghaya: > VIII; Zabadani: > VIII; Ras Baalbak: VIII; Al-Qunaytra: VIII; Damascus: VII-VIII; Beirut: VII-VIII; Sidon: VII-VIII; Safad: VII-VIII; Sur: VII-VIII; Tripoli: VII; Acre: VII; Homs: VI-VII; Hama: VI-VII; An-Nasra: VI-VII; Hosn Al-Akrad: VI-VII; Lattakia: V-VI; Al-Quds: V-VI; Gaza: V-VI; Antioch: V-VI; Aleppo: V; Tarba: V; Anatolia: IV; Egypt: IV (fig. 20). Faulting along the Bekaa valley. Landslides near Mukhtara and Deir Marjirjos. Tsunami at Acre. Aftershocks.

Parametric catalogues

- Plassard and Kogoj (1981): 1759 November $25, I=X$, it was an earthquake that caused destruction in Shouf and 100 persons were killed, it also caused destruction in Baalbak, Ras Baalbak, Hasbaya, Beit Jin and Northern Syria (Jalfaq; Perrey; Sieberg).

- Ben-Menahem (1979): 1759 November 25, $33.8 \mathrm{~N}, 36.2 \mathrm{E}, I_{0}=\mathrm{X}-\mathrm{XI}, M_{l}=6.8$, great destruction at Baalbak. A part of Damascus destroyed. Damaged area extends to Antioch and Yafa. Safad $M_{M}=$ VIII. Many thousands of persons were reported to have perished in the Bekaa (Amiran; Plassard and Kogoj; Seiberg).

Seismological compilations

- Sieberg (1932): 1759 November 25, a destructive earthquake destroyed $1 / 3$ of Damascus. Many places in Lebanon were strongly damaged. In Baalbak, there was heavy damage, 12 huge columns of the Temple fell down. It was felt in Antioch and Yafa. Aftershocks continued to the end of the month, causing a few houses to fell.

Monographs

- Ambraseys and Barazangi (1989): 1759 November $25,33.7 \mathrm{~N}-35.9 \mathrm{E}, M_{s}=7.4$, tsunami and faulting. It is the main shock of the 1759 earthquakes, lasted about $50 \mathrm{~s}$. It destroyed totally all villages in a narrow zone extending to the $\mathrm{NE}$ 


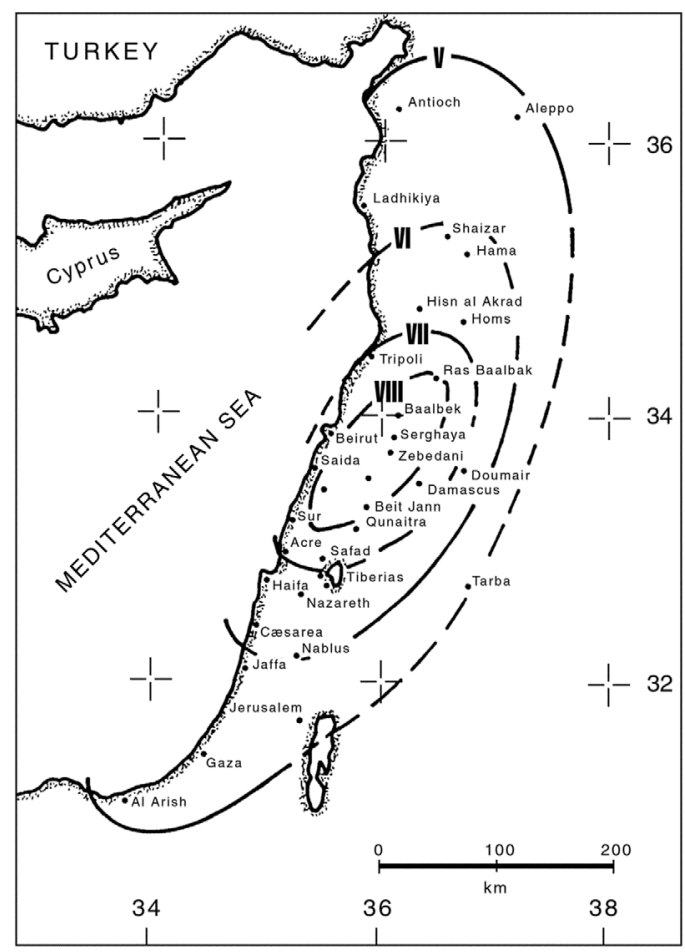

Fig. 20. Map of intensity distribution for November 25, 1759 earthquake (Ambraseys and Barazangi, 1989).

for about $120 \mathrm{~km}$ along the Litani and the Bekaa Valleys into the upper reaches of the Orontes River in NW Syria. Safad was almost totally destroyed with loss of life. The Metwali settlements, Bshara and in the Shouf region, were razed to the ground. Near Mukhtara and Mar Djerjos, rock falls and landslides took place and added to the damage. In Serghaya and Hasbaya, there was heavy destruction. Baalbak was totally destroyed with great loss of life, a landslide was dammed the supplied water up. Heavy damage extended to Ras Baalbak. The available evidence suggests that within this area of maximum damage the earthquake was associated with extensive faulting for at least $100 \mathrm{~km}$. In Damascus district, many villages in the Ghutah and Marj suffered mainly from foundation failures. The shock caused great panic in Damascus with several casualties and damage, of the 15000 mainly adobe houses, very few collapsed completely but many were badly cracked, the Umayyad mosque, other mosques, medreses, gates, baths and walls suffered different degrees of damage, a few minarets were thrown down causing additional damage to adjacent houses, part of the Damascus Citadel crumbled into the Banas canal damming its flow, in Salihiyeh (north part of Damascus), damage was more serious, European consuls estimated loss of life at a few handred lives as compared to 6000-20000 given by local sources in Damascus. It was strongly felt in Antioch and Lattakia, causing some panic and collapse of a number of old houses. In Aleppo, it lasted two minutes and a few walls were fissured. It was also felt in Tarba, Gaza and Al-Arish and a few old Khans were damaged. The shock was felt throughout Anatolia as far as Nakhichevan and in Egypt. A seismic sea wave associated with this earthquake was noted as far south as the Nile Delta without any damage. In Acre, ships were thrown onto the shore with some casualties. The total estimated killed number by various temporary writrers vary between 10000-40000. Aftershocks continued to be felt till August 1760 (Al-Budayri; Archives British Legations; Archives Historiques Ch. Comm. Marseille; ANF; Ben Zvi; Dahman; Findikli; Vitaliano; Yaari).

〈154〉 1810 Baalbak: VI; Tripoli: VI; Syria: III; Palestine: III.

Parametric catalogues

- Plassard and Kogoj (1981): 1810, I= VII, an earthquake caused light damage near Baalbak and in Lebanon, a house in Tripoli was destroyed, it was felt in Syria and Palestine (Diaire des Pères Lazaristes de Tripoli; Willis).

〈161〉 1837 January 1, 04:00 p.m. (local time) Safad: VII-VIII; Nablus: VII-VIII; Beit Lahm: VII-VIII; Al-Khalil: VII-VIII; Tabariya: VII; Beirut: VI-VII; Damascus: VI. Tsunami at the lake of Tabariya. Aftershocks. Parametric catalogues

- Ben-Menahem (1979): 1837, January 1, 14h $34 \mathrm{~m}, 33.0 \mathrm{~N}, 35.5 \mathrm{E}$, near Safad, $I_{0}=\mathrm{IX}$, $M_{l}=6.4$, destructive in Safad and Tiberias. 5000 victims. Damage at Sur, Sidon, Damascus and Beirut. Tsunami in the lake of Galilee (Amiran; 
Braslawy; Karnik; Plassard and Kogoj; Sieberg; Vered and Striem; Willis).

- Plassard and Kogoj (1981): 1837 January 1, $I=\mathrm{IX}$, an earthquake caused destruction in Shouf, Palestine, Safad (5000 persons killed?) and Tiberias (700 persons killed and there was agitation of the lake water and elevation of temperature of the thermal sources), in Beirut there was large damage and panic, there was damage in Damascus (Shalem; Sieberg).

Seismological compilations

- Sieberg (1932): 1837 January 1, a destructive earthquake in the Galilea killed a large number of people. It was felt in Cyprus. Safad was near completely destroyed and it was said that 10005000 were killed. In Tabrias, most of the houses and a large part of its wall fell down, with a loss of 700 lives. Temperature of the springs increased. There was a tsunami in the lake of AlHuleh. Zone of destruction extended from Jesreel niderung till Beirut. Another zone of destruction extended from Nablus through Beit Lahm till AlKhalil. Aftershocks continued till end of January in the Galilea region, especially in Safad. On 24 January many houses at Sur were destroyed.

Monographs

-Ambraseys (1997): 1837 January 1 at about four in the afternoon, its epicentral area extended from beyond Safad into Lebanon, $M_{s}>7.0$, there is no conclusive field evidence that this event was associated with surface faulting. There was a destructive earthquake lasting about $20 \mathrm{~s}$ which caused heavy damage in Southern Lebanon and Northern Palestine. Destruction was done along the relatively narrow zone which extended from the coastal area of Saida through the inland ikilmi of Al-Touffa, Marjuyum, Bshara to lake Taberias. In Beirut, the earthquake caused panic and about eight houses collapsed killing two people. Saida was almost totally ruined with the loss of 7 lives. Much of Banyas was ruined. Sur suffered considerable damage where 40 houses collapsed killing 16 and injuring 36 people. Bint Jubayl was ruined with the loss of 8 lives. In Safad, the largest of places affected with 2158 deaths. At Acre, about houses fell, 4 people were killed and several injured. Also in the district of Acre, 141 people were killed. In Tiberias, about two thirds of the houses collapsed killing 822 people and injuring 65. In Nazareth, only one house collapsed and one quarter of the dwellings suffered killing 7 people. In Nablus, one quarter of the houses and a number of shops were ruined causing the loss of 48 lives. In Damascus, about 2000 houses were slightly damaged, 4 minarets and several houses were destroyed and about 10 people were killed or injured. Bazaars were damaged and parts of the city gates as well as several. At the port of Jaffa the shock threw merchandise from stacks while it was slow in Ramala. In Jerusalem, the earthquake was not very strong. The shock was felt all along the coast such as in Tripoli, Lattakia, Antioch as well as in Aleppo and at Kilis. Also it was felt in the Nile Delta, at Damietta and Cairo. The earthquake was also felt in Famagusta and Larnaca. Aftershocks continued to be felt for almost 4 months e.g., 16, 22, 25 January and 20 May were the most important. The loss of life due to this earthquake and its aftershocks was larger than 6000-7000 deaths (AMAE CADN; Archives Dép. des Bouches du Rhône; Archives Société de Géographie; Archives: Abdin Palace, Athene, Correspondenzblatt, L'Echo du Monde Savante, Journal de Smyrne, Das Morgenland, Natur und Heilkunde; FO).

\section{〈163〉 1845 February 21 Antioch: V; Cyprus:} III.

Parametric catalogues

- Plassard and Kogoj (1981): 1845 February 21, $I=$ III, a strong earthquake occurred in Antioch. It was felt in Cyprus (Ambraseys, 1961, 1963).

$\langle 174\rangle 1873$ November 4 Sidon: III.

Parametric catalogues

- Plassard and Kogoj (1981): 1873 November 4, I= III (in Lebanon), an earthquake was felt at Sidon (Diaire des Pères Jésuites de Saida; Journaux Contemporains des Événments).

$\langle 175\rangle 1877$ February 26 Sidon: III.

Parametric catalogues

- Plassard and Kogoj, 1981: 1877 February 26, $I=$ III, an earthquake was felt at Sidon (Diaire des Pères Jésuites de Saida; Journaux Contemporains des Événments).

$\langle 176\rangle$ 1881 January 23, 17:45 (local time) Sidon: III.

Parametric catalogues 
- Plassard and Kogoj (1981): 1881 January 23, $I=$ III (in Lebanon), an earthquake was felt at Sidon (Diaire des Pères Jésuites de Saida; Journaux Contemporains des Événments; Sieberg).

\section{Discussion and conclusions}

This catalogue represents a comprehensive databank on the historical earthquakes for Syria and the surroundings covering 35 centuries, and will serve in studying the seismic hazards of the region. It is a unified seismological compilation and parametric catalogue. While it is certain that many small earthquakes must be missing due to many reasons, we can say that the total number of the historical earthquakes in and around Syria for the period between the 14th century B.C. and the 19th century A.D. amounts to 181 events. The 1365 B.C. earthquake in Ugharit was the first documented one to be mentioned in the catalogue. The most extensive and disastrous appear to have been those of 53 A.D., 494, 502, 551, 747, 849, 859-860, 1114, 1157, 1170, 1202, 1404, 1408, 1705, 1759, 1796, 1822, 1837 and 1872. They caused considerable damage and killed a large number of people in Syria and Lebanon. Most these events were preceded and followed by some damaging shocks, some of them causing significant destruction and large loss of life. On the other hand, they were associated with earthquake hazards such as faulting raptures, liquefaction, landslides, tsunamis and fires.

Parameters of 36 historical events are included in table I. Also, fig. 21 is a distribution of these events. These destructive earthquakes and others

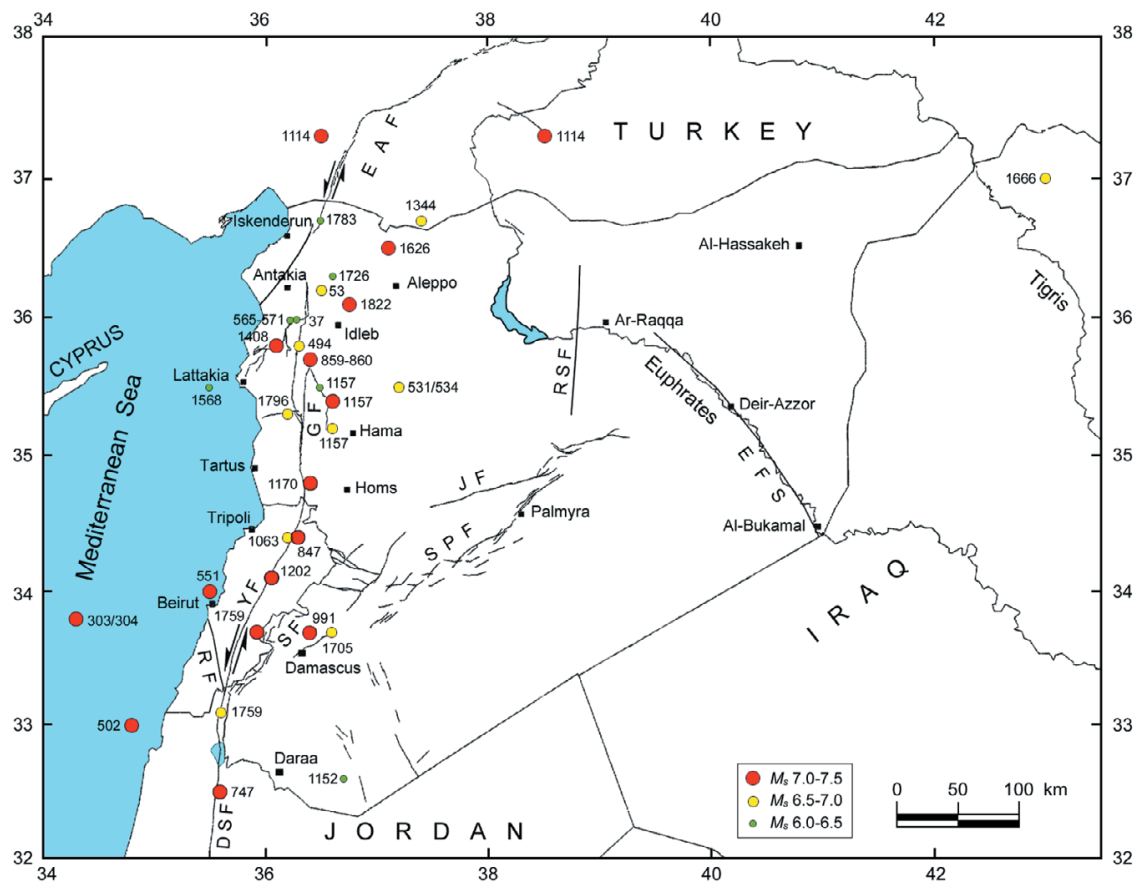

Fig. 21. Map of Syria and the surroundings showing the distribution of historical earthquakes epicenters (circles). Dates of earthquakes are listed in table I. DSF - Dead Sea Fault system; EAF - Eastern Anatolian Fault system; EFS - Euphrates Fault System; GF - Al-Ghab Fault; RSF - Ar-Rassafeh Fault; RF - Roum Fault; SF Serghaya Fault; SPF - Southern Palmyride Fault; YF - Al-Yammouneh Fault (faults are compiled from McBride et al., 1990; Barazangi et al., 1993; Gomez et al., 2001). 
presented in the catalogue occurred primarily as a result of movement of the northern segment of the Dead Sea fault system (Al-Yammouneh in Lebanon and Al-Ghab in Syria) and of the Eastern Anatolian fault system. While few large earthquakes occurred along the Palmyra, Ar-Rassafeh and the Euphrates faults. Table II is a complete list of historical earthquakes with estimated intensities at relevant localities and accompanying effects, with information completeness (A - complete; $\mathrm{B}$ accepted; $\mathrm{C}$ - uncomplete) and information quality factors ( 1 - good source quality; 2 - moderate source quality; 3 - poor source quality).

The general conclusion of this paper is that the historical seismicity of Syria is relativelywell documented now, and that Western Syria and Lebanon are the most seismic regions, while the Palmyra, Ar-Rassafeh, the Euphrates and the
Jabal Al-Arab regions have less seismic activity. Consequently, the earthquake hazards may be genuine in the Western Syria and Lebanon, the region that is the most densely populated where both regions include the larger cities such as Damascus, Beirut, Aleppo, Homs, Hama, Tripoli, Idleb, Lattakia, Tartus, Daraa, Akka, Saida, Zahleh, Baalbak Al-Qunaytra and Antakia.

Comparing both instrumentally recorded (figs. 2 and 22) and historical earthquakes (figs. 21 to 23) for the northern extension of the DSF in Syria and Lebanon, one can easily see that there is a clear difference between these two periods. In fact, the instrumental seismicity represents an apparent quiescence that does not reflect the potential hazard. It is, therefore, recommended that consideration of historical period is essential when assessing seismic hazard in this region.

Table II. A complete table of historical earthquakes with estimated intensities at relevant localities and accompanying effects, with information completeness (A - complete; $\mathrm{B}$ - accepted; $\mathrm{C}$ - incomplete) and information quality factors ( 1 - good source quality; 2 - moderate source quality; 3 - poor source quality)

\begin{tabular}{|c|c|c|c|c|c|}
\hline No. & Date & Intensity distribution & Surface effects & Completeness & Quality \\
\hline 001 & $\sim 1365$ B.C. & Ugharit: VIII-IX. & Tsunami, fire. & $\mathrm{C}$ & 2 \\
\hline 002 & 590 B.C. & Tyre: VII? & $\begin{array}{l}\text { Tsunami at the } \\
\text { Lebanese coast. }\end{array}$ & $\mathrm{C}$ & 3 \\
\hline 003 & 525 B.C. & $\begin{array}{l}\text { Tyre: VIII-IX; Sidon: VIII-IX; } \\
\text { Kiklades island: III-IV; } \\
\text { Eubea island: III-IV. }\end{array}$ & $\begin{array}{l}\text { Tsunami at the } \\
\text { Lebanese coast. }\end{array}$ & B & 3 \\
\hline 004 & 331 B.C. & Syria: VI. & & $\mathrm{C}$ & 3 \\
\hline 005 & 199-198 B.C. & Sidon: VIII; Syria: $\leq$ VII. & Landslide at Sidon. & $\mathrm{C}$ & 3 \\
\hline 006 & $\begin{array}{l}\text { 148-130 B.C. } \\
\text { February } 21, \\
\text { afternoon }\end{array}$ & Antioch: $\geq$ VII. & & $\mathrm{C}$ & 3 \\
\hline 007 & 92 B.C. & Syria: III-IV; Egypt: III-IV. & $\begin{array}{l}\text { Tsunami at the } \\
\text { Syrian-Lebanese coasts. }\end{array}$ & $\mathrm{C}$ & 3 \\
\hline 008 & 65 B.C. & $\begin{array}{l}\text { Syria: VII-VIII; Antioch: } \\
\text { VII-VIII; Al-Quds: VI; } \\
\text { Cyprus: III-IV; Salamis: } \\
\text { III-IV; Famagusta: III-IV. }\end{array}$ & & B & 3 \\
\hline 009 & $\begin{array}{l}37 \text { B.C. } \\
\text { March 23, } \\
\text { morning }\end{array}$ & Dafneh: VI-VII; Antioch: V. & & $\mathrm{C}$ & 3 \\
\hline 10 & 19 A.D. & $\begin{array}{l}\text { Sidon; Palestine; Syria; } \\
\text { Asia Minor. }\end{array}$ & & $\mathrm{C}$ & 3 \\
\hline 011 & 37 A.D. & $\begin{array}{l}\text { Antioch: VII-VIII; Dafneh: } \\
\text { VII; Al-Quds: IV. }\end{array}$ & & $\mathrm{C}$ & 3 \\
\hline
\end{tabular}


Table II (continued).

\begin{tabular}{|c|c|c|c|c|c|}
\hline No. & Date & Intensity distribution & Surface effects & Completeness & Quality \\
\hline 012 & 47 & Antioch: VII. & & $\mathrm{C}$ & 3 \\
\hline 013 & 53 & $\begin{array}{l}\text { Antioch: VII-VIII; } \\
\text { Afamia: VI-VII; } \\
\text { Manbej: VI-VII; } \\
\text { Lattakia:VI-VII (fig. 15). }\end{array}$ & & B & 3 \\
\hline 014 & $82-94$ & Antioch: VI-VII; Syria. & Aftershocks. & $\mathrm{C}$ & 3 \\
\hline 015 & 115 December 13 & $\begin{array}{l}\text { Antioch: VII; Eleyah: VI } \\
\text {-VII; Mirana: VI-VII; } \\
\text { Rhodos: IV; Pitana. }\end{array}$ & $\begin{array}{l}\text { Tsunami at Caesaria, } \\
\text { the Lebanese coast } \\
\text { and Yavne. }\end{array}$ & B & 2 \\
\hline 016 & 130 & $\begin{array}{l}\text { Damascus: V-VI; Baalbak: V; } \\
\text { Eastern Mediterranean region. }\end{array}$ & Aftershocks. & $\mathrm{C}$ & 3 \\
\hline 017 & 160 October & Dura Europos: $\geq$ VI. & & $\mathrm{C}$ & 3 \\
\hline 018 & 220 & Antioch: VI. & Aftershocks. & $\mathrm{C}$ & 3 \\
\hline 019 & 233 & Damascus: VII. & & $\mathrm{C}$ & 3 \\
\hline 020 & $242-245$ & $\begin{array}{l}\text { Antioch: VI-VII; Syria: VI- } \\
\text {-VII; Egypt: III; Iran: III. }\end{array}$ & & B & 3 \\
\hline 021 & 272 & Antioch: VI; Syria: VI. & & $\mathrm{C}$ & 3 \\
\hline 022 & $303-304$ & $\begin{array}{l}\text { Sidon: VIII; Tyre: VIII; } \\
\text { Syria: VII; Al-Quds: III-IV. }\end{array}$ & Tsunami at Caesaria. & B & 2 \\
\hline 023 & 341 & Antioch: VI-VII; Beirut: VII. & Aftershocks. & $\mathrm{C}$ & 2 \\
\hline 024 & $348-349$ & Beirut: VII; Arwad: VI. & Tsunami? & $\mathrm{C}$ & 3 \\
\hline 025 & $\begin{array}{l}363 \text { May } 18-19, \\
\text { night }\end{array}$ & $\begin{array}{l}\text { This earthquake destroyed } \\
\text { Palestine and parts } \\
\text { of Jordan, Panyas: VII. }\end{array}$ & & $\mathrm{C}$ & 2 \\
\hline 026 & 394-396 & Antioch: V-VI. & & $\mathrm{C}$ & 3 \\
\hline 027 & $\begin{array}{l}450-457 \\
\text { September }\end{array}$ & Tripoli: VI-VII. & & $\mathrm{C}$ & 3 \\
\hline 028 & 458 September & Antioch: VII-IX. & & $\mathrm{C}$ & 2 \\
\hline 029 & 475 September & Jableh: VII-VIII. & & $\mathrm{C}$ & 3 \\
\hline 030 & 494 & $\begin{array}{l}\text { Antioch: VII, Tripoli: VI-VII; } \\
\text { Lattakia: VI-VII; Beirut: V. }\end{array}$ & & B & 3 \\
\hline 031 & 500 & Antioch; Seleucea; Orfa; Safad. & & $\mathrm{C}$ & 3 \\
\hline 032 & $\begin{array}{l}502 \text { August } 22, \\
\text { Friday }\end{array}$ & $\begin{array}{c}\text { Akka: VIII; Tyre: VII-VIII; } \\
\text { Sidon: VII-VIII; Beirut: VII; } \\
\text { Palestine: VI; Safad: VI?; } \\
\text { Reina: VI? }\end{array}$ & & A & 2 \\
\hline 033 & 525 May & $\begin{array}{l}\text { Beirut: VII-VIII; Byblus: VII-VIII; } \\
\text { Sidon: VI-VII; Antioch: VI-VII. }\end{array}$ & Aftershocks. & A & 3 \\
\hline 034 & 526 May 20-29 & $\begin{array}{l}\text { Antioch: VIII; Dafneh: VII; } \\
\text { Seluecea: VII. }\end{array}$ & $\begin{array}{l}\text { Aftershocks. } \\
\text { Liquefaction } \\
\text { at Antioch. } \\
\text { Fire in Antioch. }\end{array}$ & B & 1 \\
\hline 035 & 528 November 29 & $\begin{array}{l}\text { Antioch: VII-VIII; } \\
\text { Lattakia: VI-VII. }\end{array}$ & & $\mathrm{C}$ & 1 \\
\hline 036 & $531-534$ & $\begin{array}{l}\text { Area between Aleppo } \\
\text { and Homs: VI-VII; Antioch: }\end{array}$ & & $\mathrm{C}$ & 2 \\
\hline
\end{tabular}


Table II (continued).

\begin{tabular}{|c|c|c|c|c|c|}
\hline No. & Date & Intensity distribution & Surface effects & Completeness & Quality \\
\hline 037 & 551 July 9 & $\begin{array}{c}\text { VI; Mesopotamia: IV. } \\
\text { Beirut: IX-X; Sur: IX-X; } \\
\text { Tripoli: IX-X; Byblus: IX-X; } \\
\text { Al-Batron: IX-X; } \\
\text { Shaqa: IX-X; Sarfand: VII-VIII?; } \\
\text { Sidon: VII-VIII; Arwad: III-IV. }\end{array}$ & $\begin{array}{l}\text { Tsunami along } \\
\text { the Lebanese coast. } \\
\text { Landslide near } \\
\text { Al-Batron. Fire } \\
\text { at Beirut (fig. 5). }\end{array}$ & A & 1 \\
\hline 038 & 553 & Antioch: V. & & $\mathrm{C}$ & 3 \\
\hline 039 & 557 & Antioch: V. & & $\mathrm{C}$ & 3 \\
\hline 040 & $565-571$ & $\begin{array}{l}\text { Antioch: VI-VII; } \\
\text { Seleucea: VI-VII; Kilikia: } \\
\text { VI; Anazrabo: VI; Orfa: IV. }\end{array}$ & & B & 1 \\
\hline 041 & $580-581$ & Antioch: VI-VII; Dafneh: VI. & & $\mathrm{C}$ & 1 \\
\hline 042 & 588 & Antioch: VI-VII. & Aftershocks. & $\mathrm{C}$ & 1 \\
\hline 043 & $601-602$ & Kilikia; Syria. & Surface faulting. & $\mathrm{C}$ & 1 \\
\hline 044 & 634 & $\begin{array}{l}\text { Aleppo: VII-VIII; } \\
\text { Palestine: IV-V. }\end{array}$ & Aftershocks. & $\mathrm{C}$ & 1 \\
\hline 045 & 639 & Antioch: IV-V. & & $\mathrm{C}$ & 3 \\
\hline 046 & 678 & $\begin{array}{c}\text { Batnan: VI-VII; Orfa: VI-VII; } \\
\text { Mesopotamia: VI. }\end{array}$ & & $\mathrm{C}$ & 1 \\
\hline 047 & 713 February 28 & $\begin{array}{l}\text { Antioch: VI-VII; } \\
\text { Aleppo: VI-VII; } \\
\text { Kennesreen: VI-VII. }\end{array}$ & Aftershocks. & $\mathrm{C}$ & 1 \\
\hline 048 & 717 December 24 & $\begin{array}{l}\text { Antioch: VI-VII; Batnan: } \\
\text { VI-VII; Orfa: VI-VII. }\end{array}$ & Aftershocks. & $\mathrm{C}$ & 1 \\
\hline 049 & $\begin{array}{l}747 \text { January } 18 \\
\text { (It seems to be } \\
\text { that there are two } \\
\text { earthquakes, } \\
\text { the first is in the } \\
\text { Southern Syria } \\
\text { while the second } \\
\text { is in the northern one } \\
\text { and Mesopotamia } \\
\text { that Manbej could } \\
\text { be affected.) }\end{array}$ & $\begin{array}{l}\text { Mt. Tabor: VII-IX; } \\
\text { Baalbak: VIII; Bosra: VII; } \\
\text { Nawa: VIII; Balqa: VIII; } \\
\text { Al-Quds: VII; Beit Qubayeh: } \\
\text { VII-VIII; Tabaryya: VII; } \\
\text { Al-Ghouta and Manbej: VII; } \\
\text { Darayya: VI; Damascus } \\
\text { and Daraa: V-VI; Ariha. }\end{array}$ & $\begin{array}{l}\text { Surface faulting and } \\
\text { liquefaction in Meso- } \\
\text { potamia. Landslide } \\
\text { at Mt.Tabor. }\end{array}$ & A & 1 \\
\hline 050 & 757 March 9 & $\begin{array}{l}\text { Habura: VII; Meso- } \\
\text { potamia; Syria; Palestine. }\end{array}$ & & $\mathrm{C}$ & 1 \\
\hline 051 & 775 & Antioch: IV. & & $\mathrm{C}$ & 3 \\
\hline 052 & 791 & $\begin{array}{l}\text { Aleppo: V; Northern } \\
\text { Syria; Palestine. }\end{array}$ & & $\mathrm{C}$ & 3 \\
\hline 053 & 8th century & Ar-Rassafeh: VII-VIII. & & $\mathrm{C}$ & 3 \\
\hline 054 & $\begin{array}{l}835 \text { January } 5- \\
\text {-December } 25\end{array}$ & Antioch: VI-VII. & Aftershocks. & $\mathrm{C}$ & 3 \\
\hline 055 & $\begin{array}{l}846 \text { August } 28- \\
-847 \text { August } 16\end{array}$ & $\begin{array}{c}\text { Antioch: > VIII; } \\
\text { Damascus: VII; Homs: VII; } \\
\text { Antioch; Al-Jazira: VI; } \\
\text { Al-Mousel: VI. }\end{array}$ & Aftershocks. & A & 3 \\
\hline
\end{tabular}


Table II (continued).

\begin{tabular}{|c|c|c|c|c|c|}
\hline No. & Date & Intensity distribution & Surface effects & Completeness & Quality \\
\hline 056 & 847 November 24 & $\begin{array}{l}\text { Damascus: VII-VIII; } \\
\text { Al-Ghouta: VII-VIII; } \\
\text { Al-Mazzeh: VII; Beit Lahya: } \\
\text { VII; Darayya: VII; Antioch: } \\
\text { VI; Al-Mousel: V. }\end{array}$ & & A & 1 \\
\hline 057 & $\begin{array}{l}\text { 853 June } 12- \\
\text {-854 June } 1\end{array}$ & Tabariya: VIII-IX. & Landslide. & $\mathrm{C}$ & 3 \\
\hline 058 & $\begin{array}{l}859 \text { December } 30- \\
-860 \text { January } 29 \\
\text { (It could be two } \\
\text { earthquakes, } \\
\text { the first one is } \\
\text { between Antioch } \\
\text { and Lattakia } \\
\text { while the second } \\
\text { is on the Euphrates.) }\end{array}$ & $\begin{array}{l}\text { Antioch: VIII; Lattakia and } \\
\text { Jableh: VIII; Homs: VII; } \\
\text { Palmyra: VII; Tarsus: VI; } \\
\text { Balis: VI; Damascus: VI; } \\
\text { Adana: VI; Al-Quds: } \\
\text { V-VI; Ar-Raqqa: V; Ras } \\
\text { Al-Ein: V; Harran: V; } \\
\text { Orfa: V; Egypt: IV (fig. 6). }\end{array}$ & Landslide. & A & 1 \\
\hline 059 & 881 May 16 & $\begin{array}{l}\text { Syria; Egypt; Meso- } \\
\text { potamia; North Africa } \\
\text { and Al-Andalus. }\end{array}$ & & $\mathrm{C}$ & 3 \\
\hline 060 & 889 & Aleppo: III-IV. & & $\mathrm{C}$ & 3 \\
\hline 061 & 894 & Northern Syria. & & $\mathrm{C}$ & 3 \\
\hline 062 & $\begin{array}{l}\text { 951 June 9- } \\
\text {-952 May } 28\end{array}$ & $\begin{array}{l}\text { Aleppo: V-VI; Raaban?; } \\
\text { Duluk ?; Tal Hamed? }\end{array}$ & Aftershocks. & $\mathrm{C}$ & 3 \\
\hline 063 & 963 July & $\begin{array}{l}\text { Izaz: VII; Northern } \\
\text { Syria: VI. }\end{array}$ & Rock-falls. & $\mathrm{C}$ & 3 \\
\hline 064 & 972 & $\begin{array}{l}\text { Antioch: VI-VII, } \\
\text { Damascus: V. }\end{array}$ & & $\mathrm{C}$ & 2 \\
\hline 065 & 991 April 5, night & $\begin{array}{l}\text { Baalbak: VIII-IX; } \\
\text { Damascus: VII-VIII; } \\
\text { Egypt: III-IV. }\end{array}$ & $\begin{array}{l}\text { Landslide, tsunami, } \\
\text { aftershocks. }\end{array}$ & $\mathrm{C}$ & 3 \\
\hline 066 & $\begin{array}{l}1002 \text { November } 10- \\
-1003 \text { October } 29\end{array}$ & Western Syria: $\geq$ VIII. & & $\mathrm{C}$ & 3 \\
\hline 067 & $\begin{array}{l}1029 \text { January } 20- \\
\text {-1030 January } 8\end{array}$ & Damascus: VII. & & $\mathrm{C}$ & 3 \\
\hline 068 & $\begin{array}{l}\text { 1042 August } 21- \\
-1043 \text { August } 9\end{array}$ & $\begin{array}{l}\text { Palmyra: > VII; Baalbak: } \\
\text { V; Tabriz: III; Egypt: III. }\end{array}$ & & B & 3 \\
\hline 069 & $\begin{array}{l}1046 \text { July } 8- \\
1047 \text { June } 27\end{array}$ & $\begin{array}{l}\text { Diyar Bakr: } \geq \text { VII; } \\
\text { Khlat: } \geq \text { VII. }\end{array}$ & & $\mathrm{C}$ & 3 \\
\hline 070 & $\begin{array}{l}1063 \text { July 30- } \\
\text {-August } 27\end{array}$ & $\begin{array}{l}\text { Tripoli: VII-VIII; } \\
\text { Lattakia: V-VI; } \\
\text { Acre: V-VI; Sur: V-VI; } \\
\text { Antioch: V (fig. 7). }\end{array}$ & & B & 1 \\
\hline 071 & 1089 & Palmyra: $\geq$ VIII. & & $\mathrm{C}$ & 3 \\
\hline 072 & $\begin{array}{l}1091 \text { September } \\
26 \text { or October } 6\end{array}$ & Antioch: VI-VII. & & $\mathrm{C}$ & 1 \\
\hline 073 & $\begin{array}{l}1094 \text { April 20- } \\
\text {-May } 18\end{array}$ & Damascus: V-VI. & & $\mathrm{C}$ & 1 \\
\hline
\end{tabular}


Table II (continued).

\begin{tabular}{|c|c|c|c|c|c|}
\hline No. & Date & Intensity distribution & Surface effects & Completeness & Quality \\
\hline 074 & 1098 January & Antioch: III; Aleppo: III. & & $\mathrm{C}$ & 3 \\
\hline 075 & $\begin{array}{l}1114 \text { November } \\
\text { (Two earthquakes } \\
\text { could be happened; } \\
\text { one at Maraash and } \\
\text { other at Orfa.) }\end{array}$ & $\begin{array}{l}\text { Maskaneh: VIII; Maraash: } \\
\text { VII-VIII; Samsat: VII-VIII; } \\
\text { Orfa: VII-VIII; Harran: } \\
\text { VII; Aleppo: V; Antioch: } \\
\text { IV (fig. 8). }\end{array}$ & Landslide. & A & 1 \\
\hline 076 & 1128 & Tyre. & Surface faulting? & $\mathrm{C}$ & 3 \\
\hline 077 & 1135 & Syria. & & $\mathrm{C}$ & 3 \\
\hline 078 & $\begin{array}{l}1137 \text { October } 19 \\
\text {-November } 16\end{array}$ & $\begin{array}{l}\text { Syria: VII; Al-Jazira: VII; } \\
\text { Al-Mousel: VII; Iraq: VII. }\end{array}$ & & $\mathrm{B}$ & 1 \\
\hline 079 & $\begin{array}{l}1138 \text { October } \\
11-26\end{array}$ & $\begin{array}{l}\text { Al-Sham: VI-VII; } \\
\text { Al-Jazira: VI-VII; } \\
\text { Aleppo: VI-VII. }\end{array}$ & Aftershocks. & $\mathrm{C}$ & 1 \\
\hline 080 & 1139 & Aleppo. & & $\mathrm{C}$ & 3 \\
\hline 081 & $\begin{array}{l}1140 \text { August } 17 \\
-1141 \text { August } 6\end{array}$ & Qalaat Sheizar: VI-VII. & & $\mathrm{C}$ & 2 \\
\hline 082 & 1152 September 27 & $\begin{array}{l}\text { Bosra: VII; Hauran: } \\
\text { VII; Syria: VII. }\end{array}$ & & $\mathrm{C}$ & 2 \\
\hline 083 & $\begin{array}{l}\text { 1156 September } \\
\text {-1159 May }\end{array}$ & $\begin{array}{c}\text { Western Syria including } \\
\text { Damascus. }\end{array}$ & $\begin{array}{l}\text { Foreshocks, aftershocks, } \\
\text { surface faulting. }\end{array}$ & $\mathrm{C}$ & 1 \\
\hline 084 & 1170 June 29 & $\begin{array}{l}\text { Damascus: VII-VIII; Homs: } \\
\text { VII-VIII; Hama: VII-VIII; } \\
\text { Al-Sham: VII-VIII; Lattakia: } \\
\text { VII-VIII; Baalbak: VII-VIII; } \\
\text { Shaizar: VII-VIII; Barin: VII; } \\
\text { Aleppo: VII-VIII; Iraq: V; } \\
\text { Al-Jazira: V; Al-Mousel: V (fig. 10). }\end{array}$ & Aftershocks, tsunami. & A & 1 \\
\hline 085 & 1182 & $\begin{array}{l}\text { Bosra: VII; Judea: VI; } \\
\text { Nablus: VI. }\end{array}$ & & $\mathrm{C}$ & 3 \\
\hline 086 & $\begin{array}{l}1202 \text { May } 20 \text {, } \\
\text { early morning }\end{array}$ & $\begin{array}{l}\text { Mount Lebanon: IX; } \\
\text { Baalbak: IX; Tyre: IX; Nablus: } \\
\text { VIII; Beit Jin: IX; Banyas: VIII+; } \\
\text { Al-Samyra: VIII+; Damascus: VIII; } \\
\text { Safita: VII; Akka: VII; Hauran: } \\
\text { VIII; Hama: VIII; Tripoli: VIII; } \\
\text { Safad: VII; Al-Quds: VI; Bosra: } \\
\text { VII-VIII; Al-Batron: VII; Jbeil: } \\
\text { VII; Beirut: VII; Marqab and Hosn } \\
\text { Al-Akrad: VII; Barin: VII; Homs: } \\
\text { VII; Tartus: VI; Aleppo: V; Antioch: } \\
\text { V; Al-Mousel: IV-V; Mesopota- } \\
\text { mia: IV; Cairo: IV; Alexandria: IV; } \\
\text { Dimyat: IV; Qus: IV; Iraq: IV; } \\
\text { Cyprus: VII?; Lesser Armenia: IV; } \\
\text { Sicily: IV; Khlat: IV; Ceuta: III?; } \\
\text { Constantinople: IV (fig. 16). }\end{array}$ & $\begin{array}{l}\text { Tsunami, landslide, } \\
\text { aftershocks. } \\
\text { : } \\
\text { : }\end{array}$ & A & 1 \\
\hline 087 & 1212 & Antioch. & & $\mathrm{C}$ & 3 \\
\hline 088 & 1222 & Kelless. & & $\mathrm{C}$ & 3 \\
\hline
\end{tabular}


Table II (continued).

\begin{tabular}{|c|c|c|c|c|c|}
\hline No. & Date & Intensity distribution & Surface effects & Completeness & Quality \\
\hline 089 & 1236 & Northern Syria: VI-VII. & & $\mathrm{C}$ & 3 \\
\hline 090 & 1242 & Syria. & & $\mathrm{C}$ & 3 \\
\hline 091 & 1254 & Northern Syria. & & $\mathrm{C}$ & 3 \\
\hline 092 & 1268 & Kilikia. & & $\mathrm{C}$ & 3 \\
\hline 093 & 1274 & Syria. & & $\mathrm{C}$ & 3 \\
\hline 094 & 1281 & Syria. & & $\mathrm{C}$ & 3 \\
\hline 095 & 1287 March 22 & $\begin{array}{c}\text { Lattakia: VII-VIII; } \\
\text { Palestine: IV; Armenia: IV. }\end{array}$ & & $\mathrm{C}$ & 3 \\
\hline 096 & 1290 & Syria. & & $\mathrm{C}$ & 3 \\
\hline 097 & $\begin{array}{l}1303 \text { August } 8 \\
\text { (It seems to be two } \\
\text { different events.) }\end{array}$ & $\begin{array}{l}\text { Cairo: VII; Alexandria: } \\
\text { VII; Damanhur: VII, Safad: } \\
\text { VII; Damascus: VI; Hama: VI; } \\
\text { Antioch: IV; Tunis: IV; Barqa: } \\
\text { IV; Morocco: IV; Cyprus: IV; } \\
\text { Istanbul: IV; Sicily: IV. }\end{array}$ & Tsunami, flood. & A & 2 \\
\hline 098 & $\begin{array}{l}\text { 1322 January 20- } \\
\text {-February } 19\end{array}$ & Damascus: V. & & $\mathrm{C}$ & 2 \\
\hline 099 & $\begin{array}{l}1339 \text { January } 13 \\
\text {-February } 11\end{array}$ & Tripoli: VII, Palestine: IV. & & $\mathrm{C}$ & 3 \\
\hline 100 & 1344 January 2 & $\begin{array}{l}\text { Al-Rawendan: VIII; Manbej: } \\
\text { VII-VIII; Aleppo: VI-VII; } \\
\text { Damascus: IV. }\end{array}$ & & B & 1 \\
\hline 101 & 1355 & Syria; Armenia; Palestine. & & $\mathrm{C}$ & 3 \\
\hline 102 & 1399 September 20 & Damascus: III-IV. & & $\mathrm{C}$ & 3 \\
\hline 103 & 1403 December 18 & Aleppo: IV-V. & & $\mathrm{C}$ & 3 \\
\hline 104 & 1404 February 20 & $\begin{array}{l}\text { Qalaat Blatnes: VIII; } \\
\text { Bkas: VIII; West of Aleppo: } \\
\text { VII-VIII; Qalaat Al-Marqeb: } \\
\text { VII-VIII; Tripoli district: VII, } \\
\text { Lattakia: VII; Jableh: VII. }\end{array}$ & Tsunami, landslide. & A & 2 \\
\hline 105 & $\begin{array}{l}1404 \text { November 5- } \\
\text {-December } 4\end{array}$ & Aleppo: V. & & $\mathrm{C}$ & 3 \\
\hline 106 & $\begin{array}{l}\text { 1407 April 9- } \\
\text {-May } 8\end{array}$ & Antioch: VII; Cyprus: V. & Surface faulting. & $\mathrm{C}$ & 3 \\
\hline 107 & 1408 December 29 & $\begin{array}{l}\text { Shugr: VIII-IX; Bkas: VIII- } \\
\text {-IX; Blatnes: VIII; Lattakia: } \\
\text { VII; Jableh: VII; Antioch: VII; } \\
\text { Syrian coast: VI (fig. 17). }\end{array}$ & $\begin{array}{l}\text { Faulting between Sfuhen } \\
\text { and Al-Quseir. Landslide } \\
\text { in Sfuhen. Tsunami } \\
\text { in Lattakia. }\end{array}$ & 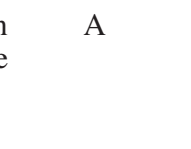 & 2 \\
\hline 108 & $\begin{array}{l}\text { 1484 March 29- } \\
\text {-April } 27\end{array}$ & Aleppo: V-VI. & & $\mathrm{C}$ & 3 \\
\hline 109 & 1491 April 24 & $\begin{array}{l}\text { Nicosia: VII; Limassol: VII; } \\
\text { Famagusta: VII; Paphos: } \\
\text { VII; Damascus: IV; Cairo: } \\
\text { IV; Crete: IV. }\end{array}$ & & A & 2 \\
\hline 110 & 1537 January 7 & $\begin{array}{l}\text { Antioch: VII; Damascus: IV; } \\
\text { Dimyat: IV-V; Egypt: IV. }\end{array}$ & & B & 1 \\
\hline
\end{tabular}


Table II (continued).

\begin{tabular}{|c|c|c|c|c|c|}
\hline No. & Date & Intensity distribution & Surface effects & Completeness & Quality \\
\hline 111 & 1537 March 08 & Damascus: IV. & & $\mathrm{C}$ & 2 \\
\hline 112 & 1546 September 29 & $\begin{array}{l}\text { Nablus: VI-VII; Damascus: } \\
\text { V; Al-Quds: VI; Yafa: VI; } \\
\text { Tripoli: VI; Famagusta: V. }\end{array}$ & Tsunami at Cyprus. & A & 3 \\
\hline 113 & 1563 September 13 & Damascus: VI. & & $\mathrm{C}$ & 2 \\
\hline 114 & 1565 July 26 & Damascus: V. & & $\mathrm{C}$ & 2 \\
\hline 115 & 1568 October 10 & $\begin{array}{l}\text { Lattakia: VII; Famagusta: V; } \\
\text { Limassol: IV; Nicosia: IV. }\end{array}$ & & B & 3 \\
\hline 116 & 1577 & $\begin{array}{c}\text { Northern Syria: VI-VII; } \\
\text { Palestine: IV; Cyprus: IV; } \\
\text { Armenia: IV. }\end{array}$ & Aftershocks. & B & 3 \\
\hline 117 & 1604 March 13 & Damascus: V, Bekaa: V. & & $\mathrm{C}$ & 2 \\
\hline 118 & 1606 October 19 & Baalbak: IV. & & $\mathrm{C}$ & 2 \\
\hline 119 & 1610 March 7 & Aleppo: VI. & & $\mathrm{C}$ & 2 \\
\hline 120 & 1616 July 22 & Aleppo: VI. & & $\mathrm{C}$ & 3 \\
\hline 121 & 1618 July 8 & Damascus: IV. & & $\mathrm{C}$ & 2 \\
\hline 122 & $\begin{array}{l}1618 \text { July } 23-- \\
\text {-August } 21\end{array}$ & Damascus: IV. & & $\mathrm{C}$ & 2 \\
\hline 123 & $\begin{array}{l}1619 \text { December } 8- \\
-1620 \text { November } 25\end{array}$ & Darkoush. & Landslide. & $\mathrm{C}$ & 2 \\
\hline 124 & 1626 January 21 & $\begin{array}{l}\text { Aleppo: VIII-IX; Gaziantab: } \\
\text { VIII-IX; Hama: VI-VII; } \\
\text { Damascus: V (fig. 11). }\end{array}$ & & $\mathrm{B}$ & 2 \\
\hline 125 & 1627 November 24 & Damascus: V. & & $\mathrm{C}$ & 2 \\
\hline 126 & 1640 & $\begin{array}{l}\text { Damascus: VI; } \\
\text { Syria; Tabriz. }\end{array}$ & & $\mathrm{C}$ & 3 \\
\hline 127 & 1656 February & $\begin{array}{l}\text { Tripoli: VII, } \\
\text { Palestine: IV. }\end{array}$ & & $\mathrm{C}$ & 3 \\
\hline 128 & 1657 & Aleppo: IV. & & $\mathrm{C}$ & 3 \\
\hline 129 & 1666 September 22 & $\begin{array}{l}\text { Al-Mousel: VII-VIII; Sinjar: } \\
\text { VI-VII; Sharqat: VI-VII; } \\
\text { Aleppo: V; Tabriz: V; Van: V. }\end{array}$ & $\begin{array}{l}\text { Landslides, } \\
\text { aftershocks. }\end{array}$ & A & 2 \\
\hline 130 & 1680 March 22-23 & Aleppo: IV. & & $\mathrm{C}$ & 3 \\
\hline 131 & 1683 & Safineh. & Landslides. & $\mathrm{C}$ & 3 \\
\hline 132 & $1693-1694$ & Northwestern Iraq. & Landslides. & $\mathrm{C}$ & 3 \\
\hline 133 & 1701 & Aleppo: IV. & & $\mathrm{C}$ & 3 \\
\hline 134 & 1705 November 24 & $\begin{array}{l}\text { Yabroud: VIII; Al-Qastal: } \\
\text { VIII; Damascus: VII; } \\
\text { Tripoli: VII. }\end{array}$ & Aftershocks. & B & 2 \\
\hline 135 & 1712 December 28 & Damascus: IV. & & $\mathrm{C}$ & 2 \\
\hline 136 & 1719 March & Aleppo: VII. & & $\mathrm{C}$ & 3 \\
\hline 137 & $1722-1723$ & Aleppo: VII. & & $\mathrm{C}$ & 3 \\
\hline 138 & 1726 April 15 & $\begin{array}{c}\text { Jum: > VII; Aleppo: VII; } \\
\text { Iskenderun: IV; Famagusta: III. }\end{array}$ & & B & 2 \\
\hline
\end{tabular}


Table II (continued).

\begin{tabular}{|c|c|c|c|c|c|}
\hline No. & Date & Intensity distribution & Surface effects & Completeness & Quality \\
\hline 139 & 1738 September 25 & $\begin{array}{l}\text { Iskenderun: VIII; Bellen } \\
\text { Bass: VII-VIII,; Antioch: VII; } \\
\text { Jabal Al-Amanus: VII; Aleppo: } \\
\text { V-VI; Kelless: V; Bereket: V. }\end{array}$ & & A & 2 \\
\hline 140 & 1752 July 21 & Lattakia: VII; Tripoli: V. & $\begin{array}{l}\text { Tsunami at the } \\
\text { Syrian coast. }\end{array}$ & $\mathrm{C}$ & 3 \\
\hline 141 & 1759 February 17 & Aleppo: V. & & $\mathrm{C}$ & 3 \\
\hline 142 & 1759 June 10 & Aleppo: IV. & & $\mathrm{C}$ & 3 \\
\hline 143 & $\begin{array}{l}\text { 1759 October } 30 \text {, } \\
\text { 03:45 (local time) }\end{array}$ & $\begin{array}{l}\text { Al-Qunaytra: VIII; Safad: } \\
\text { VII; Acre: VI; An-Nasra: VI; } \\
\text { Sidon: VI; Saasaa: VI; } \\
\text { Damascus: V; Aleppo: IV; } \\
\text { Al-Quds: IV; Beirut: IV; } \\
\text { Antioch: IV; Gaza: IV; } \\
\text { Cyprus: IV. }\end{array}$ & $\begin{array}{c}\text { Landslides at the west of } \\
\text { Damascus and Tabariya. } \\
\text { Tsunami at Acre } \\
\text { and Tripoli. Aftershocks. }\end{array}$ & f. & 1 \\
\hline 144 & $\begin{array}{c}\text { 1759 November 25, } \\
\text { 19:23 (local time) }\end{array}$ & $\begin{array}{l}\text { Baalbak: > VIII; Serghaya: } \\
\text { > VIII; Zabadani: > VIII; Ras- } \\
\text { Baalbak: VIII; Al-Qunaytra: } \\
\text { VIII; Damascus: VII-VIII; Beirut: } \\
\text { VII-VIII; Sidon: VII-VIII ; Safad: } \\
\text { VII-VIII; Sur: VII-VIII; Tripoli: } \\
\text { VII; Acre: VII; Homs: VI-VII; } \\
\text { Hama: VI-VII; An-Nasra: VI-VII; } \\
\text { Hosn Al-Akrad: VI-VII; Lattakia: } \\
\text { V-VI; Al-Quds: V-VI; Gaza: V-VI; } \\
\text { Antioch: V-VI; Aleppo: V; Tarba: V; } \\
\text { Anatolia: IV; Egypt: IV (fig. 20). }\end{array}$ & $\begin{array}{l}\text { Faulting along the } \\
\text { Bekaa valley. Land- } \\
\text { slides near Mukhtara } \\
\text { and Deir Marjrjos. } \\
\text { Tsunami at Acre. } \\
\text { Aftershocks. } \\
\end{array}$ & A & 1 \\
\hline 145 & 1760 January & Qadicha: V; Aleppo: VI. & & $\mathrm{C}$ & 3 \\
\hline 146 & 1765 & Tripoli: V; Aleppo: IV. & & $\mathrm{C}$ & 3 \\
\hline 147 & 1778 May 5 & Aleppo: IV. & & $\mathrm{C}$ & 3 \\
\hline 148 & 1779 June 8 & Aleppo: V-VI. & & $\mathrm{C}$ & 3 \\
\hline 149 & 1783 December 4 & Aleppo: IV. & & $\mathrm{C}$ & 3 \\
\hline 150 & 1783 December 14 & Aleppo: VI; Tripoli: IV. & & $\mathrm{C}$ & 2 \\
\hline 151 & 1795 January & Aleppo: VI. & & $\mathrm{C}$ & 3 \\
\hline 152 & 1796 April 26 & $\begin{array}{c}\text { Qalaat Al-Marqeb: VIII; } \\
\text { Al-Qadmous: VIII; villages } \\
\text { along Nahr Al-Kabir: VII-VIII; } \\
\text { Jableh: VII-VIII; Bkas area: VII- } \\
\text { VIII; Lattakia: VII; Saida: V; } \\
\text { Aleppo: IV; Tripoli: V. }\end{array}$ & $\begin{array}{l}\text { Landslides, } \\
\text { liquefaction. }\end{array}$ & A & 2 \\
\hline 153 & 1802 & Baalbak: VI; Palestine: III. & & $\mathrm{C}$ & 3 \\
\hline 154 & 1810 & $\begin{array}{l}\text { Baalbak: VI; Tripoli: VI; } \\
\text { Syria: III; Palestine: III. }\end{array}$ & & $\mathrm{B}$ & 3 \\
\hline 155 & 1814 & Al-Laja: VI-VII. & Rock-falls. & $\mathrm{C}$ & 3 \\
\hline 156 & 1819 February & Syria: IV-V. & & $\mathrm{C}$ & 3 \\
\hline 157 & $\begin{array}{l}\text { 1822 August } 13 \text {, } \\
\text { 09:50 p.m. }\end{array}$ & $\begin{array}{c}\text { Jisr Ash'Shoughour: IX; } \\
\text { Quseir: IX; Aleppo: VIII-IX; }\end{array}$ & Faulting, tsunami. & A & 1 \\
\hline
\end{tabular}


Table II (continued).

\begin{tabular}{|c|c|c|c|c|c|}
\hline No. & Date & Intensity distribution & Surface effects & Completeness & Quality \\
\hline & (local time) & $\begin{array}{l}\text { Darkoush: VIII-IX; Antioch: } \\
\text { VIII; Iskenderun: VIII; Idleb: } \\
\text { VIII; Sarmeen: VIII; Kelless: } \\
\text { VIII; Armanaz: VII-VIII; Sar- } \\
\text { mada: VII-VIII; Lattakia: VII; } \\
\text { Homs: VII; Hama: VII; Maraash: } \\
\text { VII; Ram Hamadan: VII; } \\
\text { Bennesh: VII; Maarret Missrin: } \\
\text { VII; Damascus: III; Gaza: III; } \\
\text { Al-Quds: III; Black Sea: III; } \\
\text { Cyprus: III (figs. 12, } 13 \text { and 14). }\end{array}$ & & & \\
\hline 158 & 1822 September 5 & Aleppo: VII. & & $\mathrm{C}$ & 3 \\
\hline 159 & 1830 & Aleppo: III. & & $\mathrm{C}$ & 3 \\
\hline 160 & 1831 February 22 & Aleppo: V. & & $\mathrm{C}$ & 3 \\
\hline 161 & $\begin{array}{l}\text { 1837 January } 1 \\
\text { 04:00 p.m. } \\
\text { (local time) }\end{array}$ & $\begin{array}{c}\text { Safad: VII-VIII; Nablus: } \\
\text { VII-VIII; Beit Lahm: VII-VIII; } \\
\text { Al-Khalil: VII-VIII; Tabariya: } \\
\text { VII; Beirut: VI-VII; Damascus: VI. }\end{array}$ & $\begin{array}{l}\text { Tsunami at the } \\
\text { lake of Tabariya. } \\
\text { Aftershocks. }\end{array}$ & A & 3 \\
\hline 162 & $\begin{array}{l}1844 \text { September } \\
19 \text { and } 30\end{array}$ & Aleppo: V. & & $\mathrm{C}$ & 3 \\
\hline 163 & 1845 February 21 & Antioch: V; Cyprus: III. & & $\mathrm{C}$ & 3 \\
\hline 164 & 1846 December 3 & Aleppo: V. & & $\mathrm{C}$ & 3 \\
\hline 165 & 1850 February 12 & $\begin{array}{l}\text { Beirut: III; Ain } \\
\text { Hamadeh: III. }\end{array}$ & & $\mathrm{C}$ & 3 \\
\hline 166 & 1854 & $\begin{array}{c}\text { Antioch: III; Suaidiya: III; } \\
\text { Beirut: III; Aleppo: III; Yafa: III. }\end{array}$ & & B & 3 \\
\hline 167 & 1859 January 24 & $\begin{array}{c}\text { Tripoli: III; Beirut: III; } \\
\text { Damascus: III; Aleppo: III. }\end{array}$ & & B & 3 \\
\hline 168 & 1864 August 15 & Aleppo: IV. & & $\mathrm{C}$ & 3 \\
\hline 169 & 1868 April 16 & Aleppo: III. & & $\mathrm{C}$ & 3 \\
\hline 170 & 1870 January 2 & Aleppo: III. & & $\mathrm{C}$ & 3 \\
\hline 171 & 1872 April 3 & $\begin{array}{l}\text { Harem:VIII; Armanaz:VIII; } \\
\text { Buhyret Al-Amq: VII-VIII; } \\
\text { Antioch: VII-VIII; Aleppo: VII; } \\
\text { Suaidiya: VII; Izaz: VI-VII; } \\
\text { Idleb: VI-VII; Iskenderun: VI-VII; } \\
\text { Hama: IV; Homs: IV; Tripoli: } \\
\text { IV; Damascus: III; Beirut: III; } \\
\text { Sidon: III; Diyar Bakr: III; Egypt: } \\
\text { III; Rhodos: III (figs. } 18 \text { and 19). }\end{array}$ & $\begin{array}{l}\text { Faulting at Baghras. } \\
\text { Liquefaction, tsunami, } \\
\text { aftershocks. }\end{array}$ & A & 1 \\
\hline 172 & 1873 February 9 & Aleppo: III. & & $\mathrm{C}$ & 3 \\
\hline 173 & 1873 February 14 & $\begin{array}{c}\text { Tyr: V; Beirut: III; } \\
\text { Al-Quds: III; Akka: III. }\end{array}$ & & B & 3 \\
\hline 174 & 1873 November 4 & Sidon: III. & & $\mathrm{C}$ & 3 \\
\hline 175 & 1877 February 26 & Sidon: III. & & $\mathrm{C}$ & 3 \\
\hline 176 & $\begin{array}{l}\text { 1881 January 23, } \\
\text { 17:45 (local time) }\end{array}$ & Sidon: III. & & $\mathrm{C}$ & 3 \\
\hline
\end{tabular}


Table II (continued).

\begin{tabular}{|c|c|c|c|c|c|}
\hline No. & Date & Intensity distribution & Surface effects & Completeness & Quality \\
\hline 177 & 1884 June 6 & Aleppo: V. & & $\mathrm{C}$ & 3 \\
\hline 178 & 1896 February 20 & Damascus: V & & $\mathrm{C}$ & 3 \\
\hline 179 & 1896 May 12 & Baalbak: V. & & $\mathrm{C}$ & 3 \\
\hline 180 & 1896 May 14 & $\begin{array}{l}\text { Antioch: V; Jisr Ash'Shoughur: } \\
\text { III; Lattakia: III; Aleppo: III; } \\
\text { Kelless: III. }\end{array}$ & & B & 3 \\
\hline 181 & 1896 June 29 & $\begin{array}{l}\text { Syria: IV; Bisri: IV; Shouf: } \\
\text { IV; Palestine: IV; Cairo: IV. }\end{array}$ & & B & 3 \\
\hline
\end{tabular}

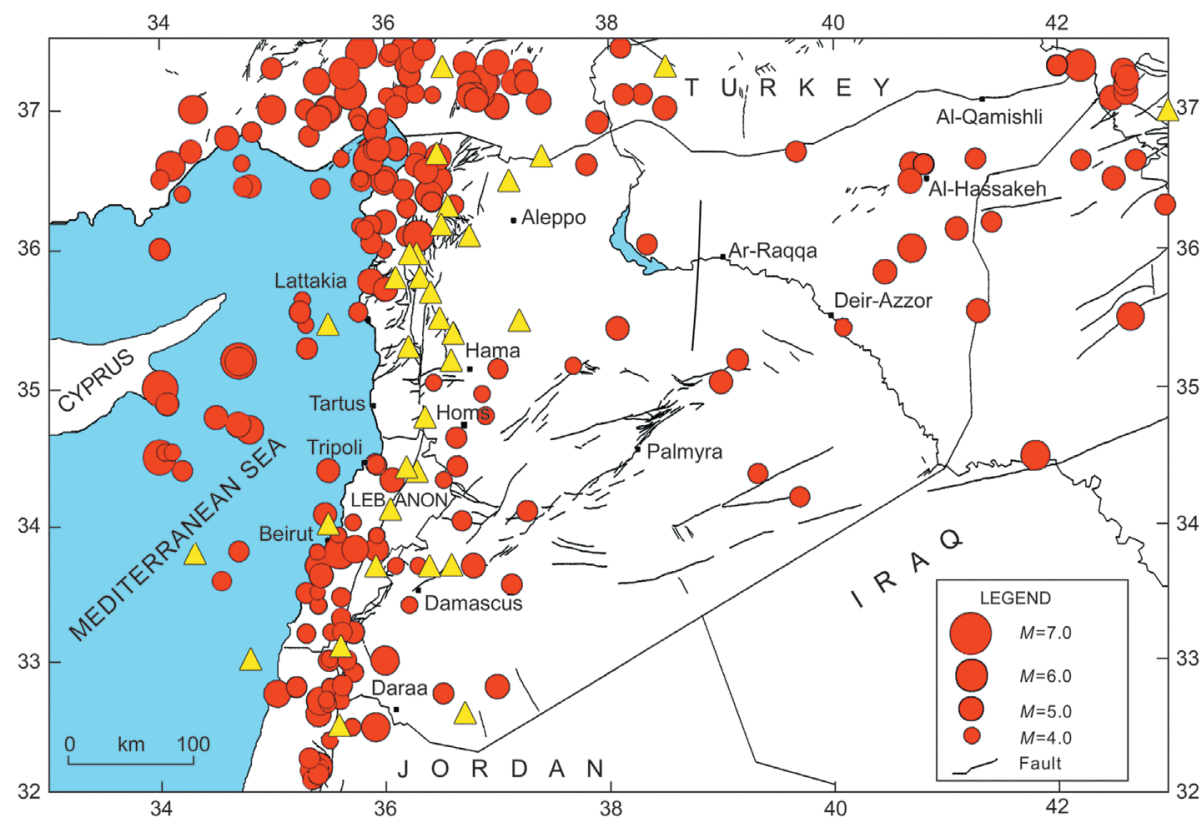

Fig. 22. Map of instrumental (red circles) and historical (yellow triangles) seismicity of Syria and surrounding region.

From the statistical point of view, a completeness test is applied to the parametric catalogue. It is found that its completeness was estimated to be at magnitude $M=6.5$. The reason that this magnitude-threshold is very high, can be explained through two factors: i) the parametric assessing of some historical earthquakes is only performed for the earthquakes that have complete descrip- tions and in the meantime affected many localities; and ii) there is some inhomogeneity with respect to the density of the description flow of the historical earthquakes along the whole time-window of the catalogue. Figure 24 shows the completeness plot of the parametric catalogue.

We believe that the coverage, to some extent, in this catalogue is still not uniform in space or 


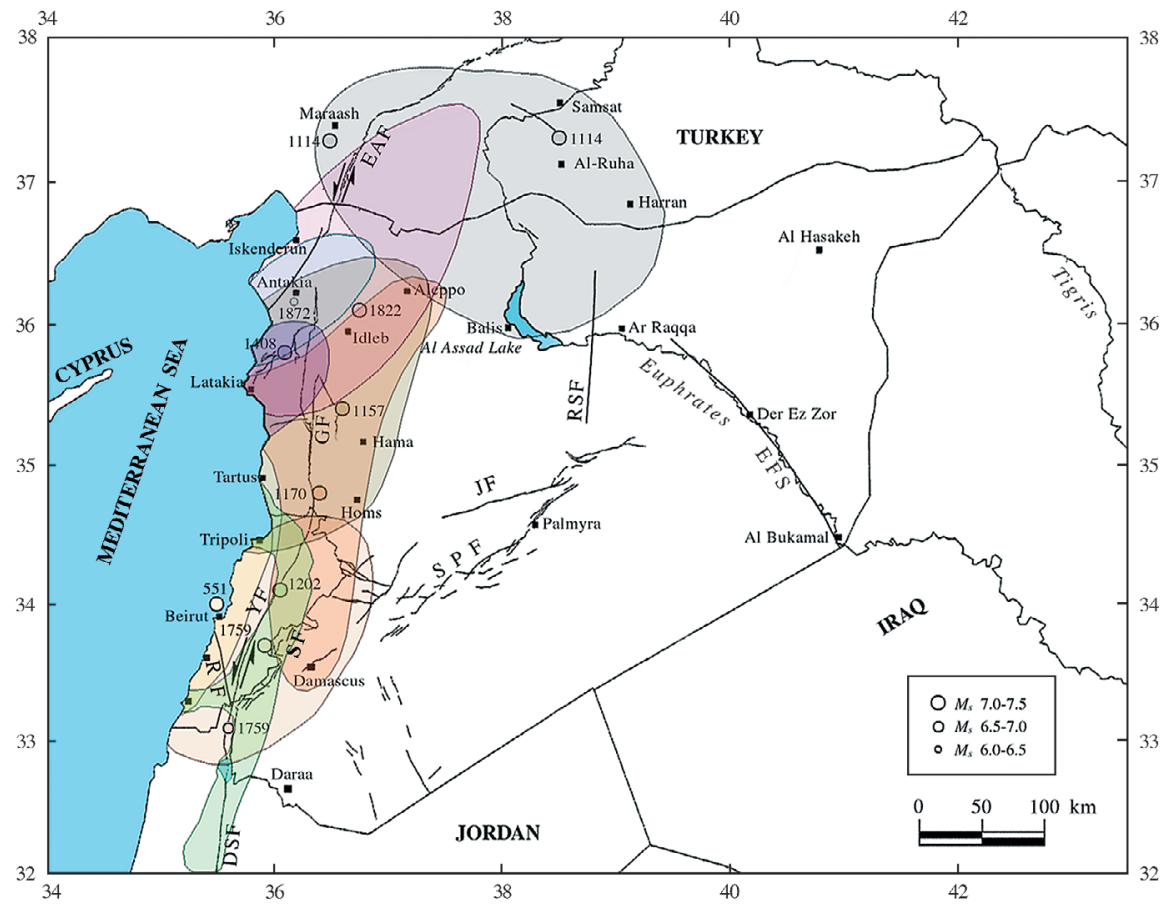

Fig. 23. Map of cumulative main historical earthquake damage distribution in Syria and surrounding region.

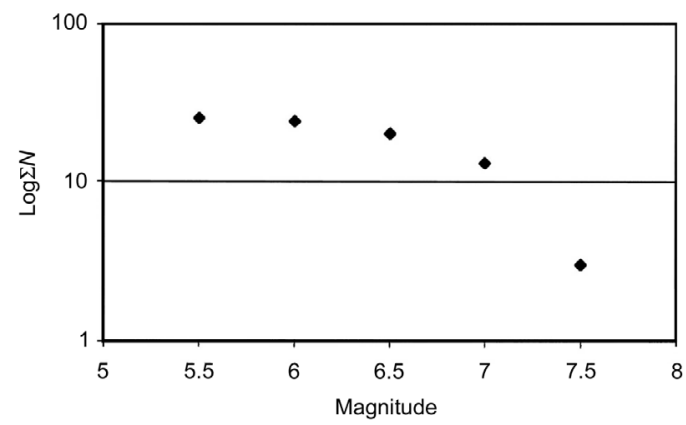

Fig. 24. The completeness plot of the parametric catalogue ( $N$ : number of earthquakes).

time. This requires further archival searches to discover unknown earthquakes and improve the data, and studies of earthquake and faulting behavior through palaeoseismic analyses should be done to identify seismotectonic behaviors of these active faults.

It is hoped that this catalogue represents a comprehensive databank on the historical seismicity covering 35 centuries, and will serve in studying the seismic hazards of the country.

\section{Acknowledgements}

We wish to thank Prof. Ibrahim Othman, Director General of the AECS.

We would also like to thank Profs. Abdul Karim Rafek, Nazem Kallas, Mohamed Muhafel and Souhail Zakkar from Damascus University, Faculty of Literatures, Department of History; Dr. Muammer Ülker, Head of the Süleymaniye Library in Istanbul and Dr. Salvatore Paolini from ENEA in Rome, for providing some historical sources. Dr. Claudio Margottini contributed in providing and analyzing some historical sources. 
We thank Profs. Nicholas A. Ambraseys (Imperial College of London) and Massimiliano Stucchi (INGV-Milan) for their review of manuscript and their comments. We are deeply indebted to Prof. Muawia Barazangi (Cornell University), Dr. Mustapha Meghraoui (IPG Strasbourg) and Dr. Francisco Gomez (Missouri University) who made thorough reading in early and recent versions of the manuscript. We are grateful to Mme. Micheline Berthélemy (Damascus) for her re-writing of the manuscript of 1822 earthquake. Many thanks to Mr. Tony Nimr (IPG Strasbourg) for his help in preparing the fig. 1. Special thanks to our colleagues from AECS-Department of geology Mr. Ihssan layyous, Mme. Rahil Saadeh and Mr. Adnan Hasan for their helping drawing some figures, and also to $\mathrm{Mr}$. Youssef Radwan for reading in the manuscript.

More information on the historical seismicity database is in <http://apamea.u-strasbg.fr>.

The preparation of the catalogue and related specific studies and investigations on individual earthquakes were funded by the International Atomic Energy Agency (contract No. 6247/ $\mathrm{R} 3 / \mathrm{RB}$ ) and partially by the APAME EC project (contract No. ICA-CT-2002-10024) General Directorate of Antiquities and museums (Ministry of Cultural).

Appendix I. Information about authors or texts cited in the catalogue.

Abû Al-Fidâ, E. (672-732 A.H., 1273-1331 A.D.): He was born in Damascus and lived partially in Cairo. He was a prince of Hama, the scientist and the historian. His book Al-Mukhtasar fi Akhbar Al-Bashar (A Summary of Human Beings News) was known and appreciated in Europe during the 17 th century. It represents his most famous work, in which many earthquakes were described.

\footnotetext{
Abu Shama, Shihab Ed-Din Abdl Rahman AlMaqdisi (559-665 A.H., 1203-1268 A.D.): He was born in Damascus. After studying, he traveled to Mecca and Al-Quds. In the year 628 A.H./1231 A.D., he was named a teacher at Rukniya and in the 662-1264 he was named teacher of the most important school of law called
}

Al-Asrafiya. His book Al-Roudhtein fi Akhbar AlDawlatein (The Two Gardens in Both Countries) is the history of both sultans Nur Ed-Din and Salah Ed-Din. In his work, he copied from some sources adding personal events or his father's events.

Agathius Scholasticus (ca. 536-582): A Byzantine poet, historian and lawyer from Myrina, who lived in Constantinople. His history of his own times begins where that of his model, Procopius of Caesarea, ends. His historical account of the reign of emperor Justinian covers events from 552 to 558 , but the work was unfinished, and was continued by Menander Protector.

Al-Antaki, Abu'l-Faraj Yahya Ibn Sa'id (980?-1066 A.D.): An Arab historian and physician, well known for his continuation of the Chronicle of Eutychius of Alexandria. He was a Melchite Christian, and lived in Egypt for the first forty years of his life. From 1014 onwards, he lived in Antioch under Byzantine rule. His sources are Islamic, Greek and Antiochene Christian.

Al-Boustani, Botrus (1234-1300 A.H., 18191883 A.D.): An Arab knowledgeable scientist who was born in Al-Dbiyya (Lebanon). His work, Dairet Al-Maaref (Cycle of the knowledge), is an encyclopedia that contains a section of Zlzala (earthquake).

Al-Budayri Al-Halak, Ahmad (18th century A.D.): He was a barber who was born at Damascus. His career assisted him to write a valuable historical book entitled Hawadith $\mathrm{Di}$ mashq Al-Yawmiyya bayn 1741 wa 1762 (Damascus daily events between 1741-1762 A.D.) which represents an eyewitness account of the 1759 A.D. earthquake.

Al-Dhahabi, Shams Ed-Din Muhammad Ibn Abdallah (1274-1348 A.D.): An Arab historian and theologian who was born in Damascus or Mayyafariqin (east of Diyar Bakr, Southern Turkey) and educated in Cairo. His major work is a Chronicle dealing with the history of Islam from its origin to the 14th century. 
Al-Ghazi, Kamal Ed-Din (586-660 A.H., 11911262 A.D.): He was born in Aleppo. He studied the law and was a historian and traveler. His most important work is Tarikh Halab (History of Aleppo). He took some information from ancient sources and personal, or parents', memories.

Al-Ghazi, Mohamad Al-Najm (?-1061 A.H., ?1651 A.D.): A historian and writer of literature who compiled many texts. He died in Damascus.

Al-Hamoui, Yakut (547-626 A.H., 1178-1229 A.D.): He is a geographic chronicler. His origin was Byzantine, captured when he was a boy and sold as a slave in Baghdad, he was released by a merchant who educated him. His surname was probably derived from his Master Askar Al-Hamoui. In his work Moujam Al-Bouldan (Dictionary of Towns), he described places, cities, towns and villages he visited.

\section{Al-Maqrizi, Taqi Ed-Din Abul Abbas Ahmad} (766-845 A.H.,1346-1442 A.D.): An Arab historian who was born in Cairo. Most of his life was in Misr (Egypt) except sometimes in Damascus. He worked in government, but then left public administration to follow his vocation as a historian. His work Al-Suluk li Maarefet Dual Al-Muluk describes the events that occurred between 568 and 845 A.H.

Al-Nablsi, Abd Al-Ghani (?-1143 A.H., ?1731 A.D.): A Damascene historian, poet and literature who compiled many texts of earthquakes. He died in Damascus.

Al-Suyuti, Jalal Ed-Din (849-911 A.H., 14451505 A.D.): An Arab polygrapher and historian, who was born in Cairo. His well work Kashf AlSalsala an Wasf Al-Zalzala (... Description of the Earthquake) represents the first compilation for about 108 earthquakes that occurred in the Arab World before and during Islam till 905 A.H.

Al-Tabakh, Mohammad Ragheb (1293-1370 A.H., 1877-1951 A.D.): An Arab historian, who was born and died at Aleppo. In his work Aalam Al-noubala'a bi Tarikh Halab Al-Shahba'a (The Famous Noblemen in the History of Aleppo), the 1237 A.H. earthquake (1822 A.D.) was mentioned in detail according to four eyewitnesses from Aleppo namely Bakri Kateb, Jawdat Basha, Mohammad Al-Termanini and Mohammad Taqi Ed-Din.

Al-Tabari, Muhammad Ibn Jarir (224-310 A.H., 839-923 A.D.): The most famous Arab historian. He was born at Amil (Tarbastan), and lived and died in Baghdad. After studying in Baghdad and then in Basra and Kufeh, he returned to Baghdad, where he spent the rest of his life as a teacher. His work Tarikh Al-Russol wa Al-Mouluk (History of Prophets and Kings), covers the period from the beginning of the Islam and the year 302 A.H., and containing ten earthquakes.

Antonini Placentini Itinerarium (6th century A.D.): This is one of the itineraries written for the use of pilgrims visiting the Holy lands in Palestine. It dates to 6th century.

Badr Al-Ghazi, Mohamad (?-984 A.H.,?1576 A.D.): A theology teacher and writer who lived in Damascus. He is a father of Mohamad Al-Najm Al-Ghazi.

Chronicle of Edessa (540 A.D.): A Syriac source written by an unknown author around 540. It mentions the 528 earthquake.

Chronicle of 724 (8th century A.D.): It was a Syriac chronicle by an unknown author covering the period from Adam to 724. It was probably written at the time of the Caliph Hisham.

Chronicle of 1234 (13th century A.D.): An anonymous Syriac chronicle written about half a century after the chronicle of Michael the Syrian. It is divided into two parts, of which one is devoted to secular history (to 1234) and the other to ecclesiastical history (to 1207).

Dio Cassius Cocceianus (2nd-3rd century A.D.): A senator during the reign of the Roman emperor Commodus (180-192 A.D.), who subsequently held other important positions. He wrote in Greek a history of Rome from its origin to 299 A.D., of which the books covering the years 68-10 B.C. have survived in their en- 
tirety. The period 9 B.C.-46 A.D. survives in abbreviated form, and the other parts are to be found in the epitomes of Xiphilinus (11th century) and Zonaras (12th century). Dio Cassius' work is based on late republican histories, the tradition imperial annals and, for contemporary events, his own experience.

Elias of Nisibis (975-1049 A.D.): He was born at Nisibis in Northern Syria, and became metropolitan of the city in 1008 . He wrote a Chronography in Syriac and Arabic, the first part of which is historiographical work coming down to 1018 and modeled on the Chronicon of Eusebius. He mentions various earthquakes in his work, but some of his dating have to be corrected in the light of other Byzantine sources.

Evagrius Scholasticus (ca. 536-600): He was born at Epiphania in Syria, and worked as a lawyer, probably at Antioch, where he wrote his Historia Ecclesiastica in 6 books. It narrates events from 431 to 594 and treats both ecclesiastical and secular history. He used sources which are now partly lost.

Fragmenta Tusculana (6th century A.D.): These fragments were discovered in the Abbey of Santa Maria at Grottaferrata (Rome). They are probably dated to the 6th century A.D.

Georgius Cedrenus (late 11th-early 12th century A.D.): A Byzantine chronicler who compiled a chronicle of the world history from the creation to the reign of the emperor Isaac I Comnenus (1057). His material comes from earlier chroniclers such as Joannes Scitre and Joannes Scylitzes.

Georgius Monachus (9th century A.D.): $\mathrm{He}$ is a Byzantine historian. Between 842 and 867, he wrote a chronicle covering the period from the creation to the year 842 . He brought together material from many ancient sources as well as from some nearer to his own day. It is very difficult to identify his ancient sources, but those for the Byzantine period are the works of Theophanes, Malalas and Nicephorus.

Ibn Al-Athir, Ezz Ad-Din (555-630 A.H., 1160-1232 A.D.): An Arab historian who was born, lived and died in Al-Mousel. He traveled often to many cities such as Baghdad, Aleppo, Damascus and Al-Quds. His book Al-Kamil fi Al-Tarikh (The Complete in History), which covers the period from the creation up to the end of 1230 A.D. and contains 56 earthquakes, represents the most famous one. He took some information from Ibn Al-Qalansi.

Ibn Al-Dawadari, Abu Bakr Ibn Abdallah (14th century A.D.): An Arab historian who was born in Egypt and lived between Egypt and Syria. His Chronicle is an important source for the history of the Fatimites, Ayyoubites and Mamluks periods.

Ibn Al-Jawzi, Abdul Rahman (510?-597 A.H., 1113?-1200 A.D.): An Arab historian who was born, lived and died in Baghdad. His work $A l$ Mountazam fi Tarikh Al-Mouluk wa Al-Oumam (The Regular in the History of Kings and Nations) is a general history, including earthquakes, from the creation up to 1185 A.D.

Ibn Al-Qalanisi, Hamzeh Ibn Assad (465-555 A.H., 1073-1160 A.D.): He was born and lived in Damascus. Following his studies in Letters, Law and Theology, he began an administrative career. He was ra'is (president) of Damascus twice. His Chronicle is the best source relating the first and second Crusader stages and the first years of Nur Ed-Din. His work Tarikh $\mathrm{Di}$ mashq (history of Damascus) was used by Ibn Al-Athir.

Ibn Al-Wardi, Omar (691-749 A.H., 12921348 A.D.): An Arab grammarian and historian, who was born at Maarret Annooman and died at Aleppo. In his work Tarikh Ibn Al-Wardi (History of Ibn Al-Wardi), numerous earthquakes occurring in Arabia before and during his life have been mentioned.

Ibn Batriq (877-940 A.D.): An Arab historian, who was Melchite Patriarch of Alexandria from 933, and opposed the Coptic Jacobites. He wrote a number of works in Arabic, notably a Chronicle, which was continued by his nephew Al-Antaki. It includes several theological discussions. 
Ibn Kathir Al-Dimashqi, Ismail Abu Al-Fida Al-Hafez (710-774 A.H., 1310-1372 A.D.): An Arab chronicler who was born in the village of Bosra and lived most of his life in Damascus. His work Al-Bidaya wa Al-Nihaya (The Beginning and the Finale) covers the period from the creation to the year 767 A.H., and includes 46 earthquakes that occurred in and around Syria.

\section{Ibn Tagri Birdi, Abu'l-Mahasin Jamal Ed-Din} yusuf (1410?-1470 A.D.): An Arab historian who was born and died in Cairo. He was a military official during the Egyptian Mamluk dynasty. He covered many important positions. He wrote a Chronicle of this dynasty, which is a primary source for the study of post-Fatimite Egypt.

John of Ephesus (507-586 A.D.): A Bishop of Ephesus and a monophysite. He wrote an ecclesiastical history in Syriac before the year 581 A.D.

Klengel, Horst: He was a director of the Berlin's museum in the 1950 s.

Lammense, Henri (1278-1356 A.H., 1862-1937 A.D.): An orientalist who was born in Belgium. He studied theology in England then lived in Beirut. He was a compiler of many books on the Arabs and Islam. He died at Beirut.

Malalas, John (ca. 491-578): He was a chronicler. His name Malalas is a Greek adaptation of the Syriac word melel, meaning «lawyer» or «rhetorician». His Chronographia, in 18 books, provides a confused and sometimes ill-ordered narrative of world history since the creation. It makes use of an extraordinary variety of sources, often misunderstanding dates and confusing events. When he comes to the 5th and 6th centuries A.D., however, he is closest to his own day, and provides interesting information, intermingled with accounts of wonders and prodigies. The fact that he shows a great deal of interest in Antioch, suggests that the work was written there.

Maronite Chronicle (2nd half of the 7th century A.D.): An anonymous Syriac chronicle, covering the period from the reign of Alexander the Great (336-323 B.C.) to the mid 660s, but there is a great lacuna from 361 to 658 . It must have been composed shortly after the latest events it covers.

Michael the Syrian (1126-1199 A.D.): A Syrian historian who was born at Melitene (Malatya). He was named patriarch of the Jacobites from 1166 onwards, and wrote a universal history from Adam to 1195 in 21 books. It has come down to us in a number of manuscripts, but all of them have eliminated certain parts. It was also translated into Arabic and Armenian. The Armenian translation, which is of only slightly later date, contains certain details which add to the surviving Syriac texts. The original work was arranged in three parallel columns, which dealt respectively with Church history, secular history and reports of prodigious events such as eclipses, earthquakes, famine etc.

Pompeus Trogus (29 B.C.-14 A.D.): A Latin historian who was born in Gallia and lived in Augustan times. He wrote De animallibus and Historiae Philippicae, the latter surviving only in an abbreviated version by Justin.

Posidonius (135-51/50 B.C.): A stoic philosopher who was born at Apamea (Turkey) and lived in Athens, Rome and Rhodes. His work embraced all areas of philosophy and natural science, but only fragments have survived. His theory of earthquakes was elaborated by his disciple Asclepiodotus and has come down to us through Seneca.

Procopius of Caesarea (end of the 5th centuryafter 565 A.D.): A Byzantine historian who was born at Caesarea in Palestine. All his writings are of a historical nature, except for Aedificia, which he wrote between 553 and 555 to describe and praise Justinian's building work throughout the Empire. He also wrote a Historia Arcana. The gothic War is his most important work.

Pseudo-Dionysius of Tellmahre (8th century A.D.): It is a chronicle written by a Christian author of about the 8th century, because it was formerly attributed to the 9th century Syrian patriarch Dionysius of Tellmahre, whose Chronicle in 16 books (of which only a few echoes re- 
main) covered events from 582 to 843 . A more correct name for our work is Chronicle of Zuquin, and it is divided into two parts, the first consisting of freely adapted excerpta from the historical works of Eusebius (the Chronicon and the Ecclesiastical History).

Pseudo-Joshua the Stylite (5th-6th century A.D.): Attributed to this Syrian writer is a chronicle of Edessa for the years around 497-505/507, which was subsequently reworked by the Jacobite patriarch Pseudo-Dionysius of Tellmahre.

Saadeh, Gabreal (1922-1997 A.D.): A Syrian historian about Lattakia and Ugharit who was born and died recently in Lattakia. He had the degree of law from Beirut in 1944, then had many positions in Lattakia. His work $A l$ Mukhtasar fi Tarikh Al-Lathiqyeh (A Summary in the History of Lattakia) consists of 7 historical earthquakes that hit Lattakia $(529,859 / 860$, 1157, 1170, 1287, 1796 and 1822).

Severus of Antioch (465-538 A.D.): Born at Sozopolis in Pisidia (Turkey), he was monophysitic patriarch of Antioch from 512 to 518 . As a result of presecution by the Chalcedonians, he was forced to flee to Alexandria in Egypt, where he spent many years. He wrote in Greek, but scarcely any of his works have survived in that language, being preserved instead in Syriac translation.

Socrates Scholasticus (380-439/450 A.D.): He is a Byzantine writer. His Historia Ecclesiastica continues the work of Eusebius from 305 A.D. up to 439 . He is primarily interested in the history of the Church.

Strabo (64 B.C.-23? A.D.): A Greek geographic historian who was born at Amasea in Pontus. His historical writings were lost, but the 17th books of his Geographia have survived. Books 3-11 are about Europe; books 11-16 are about Asia and book 17 is about Africa.

Theophanes ( $c a$. 760-818): A Byzantine chronicler who wrote a history of events from 284 to 813 A.D. for the western and eastern empires. His sources are ecclesiastical histories and chronicles, as well as historians such as Procopius and Agathias. He is the principle source for the dating of a number of earthquakes.

Zonaras, John (12th century A.D.): A Byzantine historian and writer on ecclesiastical subjects, who held an official position at the court of Constantinople. He became a monk around 1118 and retired to the Monastery of Mt. Athos. In addition to an epitome of world history from the creation to the year 1118 , he wrote various commentaries on canon law and some hymns. His sources include such important historians as Herodotus, Xenophon, Plutarch and Dio Cassius.

Appendix II. Different historical names of localities cited in the catalogue.

[Format: Current locality name(s) in Arabic and English (description): Ancient name(s), location.]

Aafrine: see Ifreen.

Acre: see Akka.

Adana (town): Southern Turkey.

Afamia (archaeological site): Apamea, northwest of Hama.

Afsiyeh: see Aq-Saya.

Aina d-Gader (village?): near Salt, Northwestern Jordan.

Ain Hamadeh: near Beirut.

Akka, Acre (city): Ptolemais, Akkô, southern Lebanese littoral.

Akkar (town): east of Tripoli, Northern Lebanon.

Akkô: see Akka.

Al-Andalus: see Espania.

Al-Assi, Orontes (river): Orontes, Western Syria.

Al-Batra, Patra, Petra (archaeological site): Southern Jordan.

Al-Batron (town): Botrys, Botro, south of Tripoli.

Al-Dbiyya (village): in Lebanon.

Aleppo: see Halab.

Al-Eskandariyeh, Alexandria (city): Northern Egypt.

Alexandria: see Al-Eskandariyeh. 
Al-Fustat: see Al-Qahira.

Al-Ghouta (plain): it surrounds Damascus from south and east.

Al-Harbyeh: see Dafneh.

Al-Hejaz, Hejaz (region): in Saudi Arabia.

Al-Jalil, Galilee (region): Northern Palestine.

Al-Jazira, Mesopotamia (region): NE of Syria and $\mathrm{N}$ of Iraq.

Al-Karak, Kerak (city): Central Jordan.

Al-Khalil, Hebron (city): Hebron, Central Palestine.

Al-Laja (hill): south of Damascus.

Al-Lathiqiyeh, Latakia (city): Rameta, Mazbada, Laodicea, Syrian coast.

Al-Led, Lod, Lydda (town): Diospolis, northwest of Al-Quds, Central Palestine.

Al-Mazzeh: a Damascene suburb.

Al-Mazzeh: a Damascene suburb.

Al-Mousel, Mosul (city): Mousel, Northern Iraq.

Al-Qadmous (town): northeast of Tartus.

Al-Qahira, Cairo (city): Al-Fustat, Northern Egypt.

Al-Qastal (village): northeast of Damascus.

Al-Quds, the Holy City, Jerusalem (city): $A l$ Quds, Central Palestine.

Al-Qunaytra (city): southeast of Damascus, Southern Syria.

Al-Rafiqa: see Ar-Raqqa.

Al-Ruha: see Orfa.

Al-Salameyeh, Salamiya (town): Salamias, southeast of Hama.

Amid: see Diyar Bakr.

Amil: in Tarbastan.

Amik Glü: see Buhyret Al-Amq.

Andalusia: see Espania.

An-Nasra, Nazareth (town): Northern Palestine. Antakia, Antakya, Antioch (city): Theopolis, Antioch, Northwestern Syria.

Antakya: see Antakia.

Antaradus: see Tartus.

Antharidus: see Arwad.

Antioch: see Antakia.

Apamia: see Afamia.

Aq-Saya, Afsiyeh (village): east of Antioch, NW of Syria.

Aradus: see Arwad.

Areopolis: see Moab.

Ariha, Riha (town): $13 \mathrm{~km}$ south of Idleb, Western Syria.
Ariha, Jericho (city): Jericho, Central Palestine.

Armanaz (town): west of Aleppo.

Arra: see Maarret Annooman.

Ar-Raqqa (city): Ar-Raqqa, Al-Rafiqa, NE Syria.

Ar-Rassafah (archaeological site): Rasaba, Sergiopolis, southwest of Ar-Raqqa.

Arwad (island): Aradus, Antharidus, Syrian coast, southwest of Tartus.

Ascalan (town): Ascalon, Southern Palestinian Littoral.

Ascalon: see Ascalan.

Ash-Sham: see Dimashq.

Ash-Sham, Bilad as-Sham (region): Syria, Lebanon, Palestine and Jordan.

As-Salihiyeh (archaeological site): Dura Europos, southeast of Deir Ez-Zor, Eastern Syria. As-Samyra, Samaria, Shamrin (archaeological site): Sebastia, northwest of Nablus.

As-Suweida (city): Soada, Southern Syria.

Atareb (town): southwest of Aleppo.

Azotus (archaeological site): south of Jaffa, southern Palestinian littoral.

Baalbak (town): Heliopolis, Eastern Lebanon.

Baghdad: in Iraq.

Baghras (village): in Antioch district.

Baishan: see Bissan.

Bakas: see Bkas.

Balis: see Maskaneh.

Bambyce: see Manbej.

Banyas (village): Banyas, southwest of Damascus.

Banyas Al-Sahel, Banyas (town): Syrian Littoral.

Barin (village): Western Syria.

Bar Lyas (village): south of Zahleh, Lebanon.

Barqa (city): in Libya.

Basut: see Basuta.

Basuta, Basut (village): NW of Aleppo.

Batnan (town): Southern Turkey.

Batrakan (village): in Antioch district.

Beilan (town): south of Iskenderun.

Beirut (city): Bêrytus, Lebanese coast.

Beit Jin (village): southwest of Damascus.

Beit Jubrin (village): southwest of Al-Quds.

Beit Lahm, Bethlehem (town): south of AlQuds, Central Palestine.

Beit Lahya (ruins of a village): few kilometers northeast of Damascus. 
Beit Qubayeh (village): around Damascus.

Beit Saho (village): east of Damascus.

Benghazi, Benighazi (city): in Libya.

Benighazi: see Bebghazi.

Bennesh (village): $7 \mathrm{~km}$ northeast of Idleb.

Beroea: see Halab.

Bêrytus: see Beirut.

Bethlehem: see Beit Lahm.

Bilad Al-Andalus: see Espania.

Bissan, Baishan (town): Northern Palestine.

Bkas, Bakas (archaeological site): near Jisr Ash'Shoughour.

Bosra: see Bosra Al-Sham.

Bosra Al-Sham, Bosra (town): Bostra, Southern Syria.

Bostra: see Bosra Al-Sham.

Botro: see Al-Batron.

Botrys: see Al-Batron.

Bucak (?): Western Syria.

Buhyret Al-Amq, Amik Glü (lake): north Antioch.

Byblus: see Jbeil.

Caesarea (town): Northern Palestinian coast.

Cairo: see Al-Qahira

Casius Mount: see Jabal Al-Aqraa.

Ceasar: see Qalaat Sheizar.

Chalcis: see Kennesreen.

Cilicia: see Kilikia.

Constantinople: see Istanbul.

Crac des Chevaliers: see Qalaat Al-Hosn.

Cyprus: see Qubrus.

Dafneh, Al-Harbyeh (town): $9 \mathrm{~km}$ southwest of Antioch.

Damanhur (city): Northern Egypt.

Damascus: see Dimashq.

Dameska: see Dimashq.

Dameski: see Dimashq.

Damietta: see Dimyat.

Daraa (city): Daraat, Southern Syria.

Daraat: see Daraa.

Darayya (village): $3 \mathrm{~km}$ south of Damascus.

Darkoush, Darkush (village): NWW of Idleb.

Darkush: see Darkoush.

Deir Marjrjos (village and archaeological site): west of Homs.

Dimashq, Ash-Sham, Damascus (city): $D a$ meski, Dameska, Ash-Sham, Southern Syria.

Dimyat, Damietta (city): NW Egypt.

Diospolis: see Al-Led.

Diyar Bakr (town): Amid, Northern Syria.
Douma (town): $7 \mathrm{~km}$ northeast of Damascus.

Duluk (village and fortress): near Gaziantab, Southern Turkey.

Dura Europos: see As-Salihiyeh.

Edessa: see Orfa.

Edlib: see Idleb.

Eleutherus: see Nahr Al-Kabir.

Emessa: see Hims.

Epiphania: see Hama.

Espania, Spain (country): Al-Andalus, Bilad Al-Andalus, Andalusia.

Euphrates: see Nahr Al-Furat.

Famagusta (city): western coast of Cyprus

Galilee: see Al-Jalil.

Gaza (town): southern Palestinian coast.

Gaziantab, Iantab (town): Southern Turkey.

Gerasa: see Jarash.

Germanicia: see Marash.

Gophna: see Jifna.

Habur, Habura (village): east southeast of Mardin, Southern Turkey.

Habura: see Habur.

Halab, Aleppo (city): Harabu, Beroea, Halab, Northern Syria.

Hama (city): Epiphania, Hamat, Hamath, Central Syria.

Hamat: see Hama.

Hamath: see Hama.

Harabu: see Halab.

Harem, Harim (town): west of Aleppo.

Harim: see Harem.

Harran (town): southeast of Sanliurfa, Southern Turkey.

Hauran (region): Hauran, region of Daraa, Southern Syria.

Hazart: see Izaz.

Hebron: see Al-Khalil.

Hejaz: see Al-Hejaz.

Heliopolis: see Baalbak.

Herapolis: see Manbej.

Hims, Homs (city): Emessa, Homs, Central Syria.

Homs: see Hims.

Hosn Al-Akrad: see Qalaat Al-Hosn.

Iantab: see Gaziantab.

Ibin (village): north of Idleb.

Idleb, Idlib (city): Northwestern Syria.

Ifreen, Aafrine (town): northwest of Aleppo.

Iskenderun (city): Miryandrous, Northwestern

Syria. 
Istanbul (city): Constantinople, Western Turkey. Izaz (town): Hazart, north of Aleppo.

Izmir (city): Smyrna, Western Turkey.

Jabal Al-Akraa (mountain): Casius Mount, Northwestern Syria.

Jabal Al-Amanus (mountain): Jabal AlLkam, Northwestern Syria.

Jabal Al-Lkam: see Jabal Al-Amanus.

Jabala: see Jableh.

Jableh (town): Jabala, Syrian coast, south of Latakia.

Jaffa: see Yafa.

Japho: see Yafa.

Jarash, Jerash (town): Gerasa, Northern Jordan.

Jbeil (town): Byblus, Lebanese coast, north of Beirut.

Jedida (village): in Antioch district, NW of Syria.

Jerash: see Jarash.

Jericho: see Ariha.

Jerusalem: see Al-Quds.

Jifna, Gophna (?): in Jordan.

Jisr Ash'Shoughour (town): southwest of Idleb.

Judea (region): Central Palestine.

Jum (village): NW of Aleppo.

Kabusi (village): in Antioch district, NW of Syria.

Kafer Tab (village): north of Hama.

Kelless, Killes, Killis (town): north of Aleppo.

Kennesreen (archaeological site): Chalcis, Qenneshrin, $20 \mathrm{~km}$ south of Aleppo.

Kerak: see Al-Karak.

Khan Sheikhoun, khan Sheikhun (town): 30

$\mathrm{km}$ north of Hama.

Khan Sheikhun: see Khan Sheikhoun.

Khlat: northeast of Diyar Bakr, Southern Turkey.

Kilikia, Cilicia (region): Southern Turkey.

Killes: see Kelless.

Killis: see Kelless.

Konya (town): Turkey.

Kufeh: in Iraq.

Labruda: see Yabroud.

Laodicea: see Al-Lathiqiyeh.

Laryssa: see Qalaat Sheizar.

Latakia: see Al-Lathiqiyeh.

Laushiya (village): in Antioch district.

Lefkosia (city): Central Cyprus.

Lejjun (citadel): Western Jordan.
Limassol (city): southern littoral of Cyprus.

Lod: see Al-led.

Lydda: see Al-Led.

Maarat: see Maarret Annooman.

Maarret Annooman, Maarat (town): Arra, south of Idleb.

Maarret Missrin (village): $12 \mathrm{~km}$ north of Idleb.

Mabbog: see Manbej.

Mabbug: see Manbej.

Makkeh, Mecca (city): in Western Saudi Arabia.

Malatya, Melitene (city): in Turkey.

Manbej (town): Bambyce, Hierapolis, Mabbug, Mabbog, northeast of Aleppo.

Maras: see Marash.

Marash, Maras (town): Germanicia, Southern

Turkey.

Marsin (town): in Kilikia, Southern Turkey.

Masada (village): Central Palestine.

Maskaneh (town): Balis, southeast of Aleppo.

Mazbada: see Al-Lathiqiyeh.

Mecca: see Makkeh.

Melitene: see Malatya.

Mesopotamia: see Al-Jazira.

Miryandrous: see Iskenderun.

Misis (town): Moposueste, Southern Turkey.

Moab (town and archaeological site): Areopolis, east of Dead Sea, in Jordan.

Moposueste: see Misis.

Mosul: see Al-Mousel.

Naba (mountain and archaeological site):

Nebo, northwest of the Dead Sea, Western Jordan.

Nablus (city): Northern Palestine.

Nahr Al-Kabir, Nahr Al-Kebir (river): Eleutherus, Northwestern Syria.

Nahr Al-Furat, Euphrates (river): in Northern and Eastern Syria.

Nahr Al-Kebir: see Nahr Al-Kabir.

Nawa (village): Neve, north of Daraa, Southern

Syria.

Nazareth: see An-Nasra.

Nebo: see Naba.

Neve: see Nawa.

Nusaybin, Nisibis (town): Northern Syria.

Nisibis: see Nusaybin.

Orfa, Urfa, Sanliurfa, Al-Ruha (town):

Edessa, Southern Turkey.

Orontes: see Al-Assi.

Palmyra: see Tadmor.

Patra: see Al-Batra. 
Payas (village): Northwestern Syria.

Petra: see Al-Batra.

Phoenician coast: coasts of Syria, Lebanon and Palestine.

Ptolemais: see Akka.

Qalaat Balatunus: see Qalaat Blatnes.

Qalaat Blatnes, Qalaat Al-Mahalbeh, Qalaat

Balatunus (citadel): east of Latakia.

Qalaat Al-Hosn, Hosn Al-Akrad, Crac des

Chevaliers (citadel): west of Homs.

Qalaat Al-Mahalbeh: see Qalaat Blatnes.

Qalaat Al-Marqeb (citadel): North Tartus, Syrian coast.

Qalaat Sheizar (citadel): Laryssa, Ceasar, northwest of Hama.

Qaramut (village): south of Iskenderun.

Qatana (town): $17 \mathrm{~km}$ southwest of Damascus.

Qenneshrin: see Kennesreen.

Qilliq (village): in Antioch district.

Quaralu (village): in Antioch district.

Qubrus, Cyprus (island and country): Eastern Mediterranean region.

Quseir (mountain): it includes Dafneh and three villages, Northwestern Syria.

Rameta: see Al-Lathiqiyeh.
Ram Hamadan (village): $10 \mathrm{~km}$ northeast of Idleb.

Rasaba: see Ar-Rassafah.

Ras Al-Ein (town): Northeastern Syria.

Ras Baalbak (village): Northern Lebanon.

Ras Shamra, Ugharit (archaeological site): Ugharit, $10 \mathrm{~km}$ north of Latakia.

Riha: see Ariha of Syria.

Saasaa (village): northeast of Al-Qunaytra.

Safad (town): Zefat, Northern Palestine.

Safita (town): southeast of Tartus.

Saida, Sidon (city): Sidon, Southern Lebanese littoral.

Salamias: see Al-Salameyeh.

Salamis (town): Western Cyprus.

Salamiya: see Al-Salameyeh.

Salfouhum: see Sfuhen.

Salqein (town): northwest of Idleb.

Samandag, Samandaği (town): southwest of Antioch.

Samandaği: see Samandag.

Samaria: see As-Samyra.

Samosta: see Samsat.

Samsat (?): Samosata, Turkey.

Sanliurfa: see Orfa.

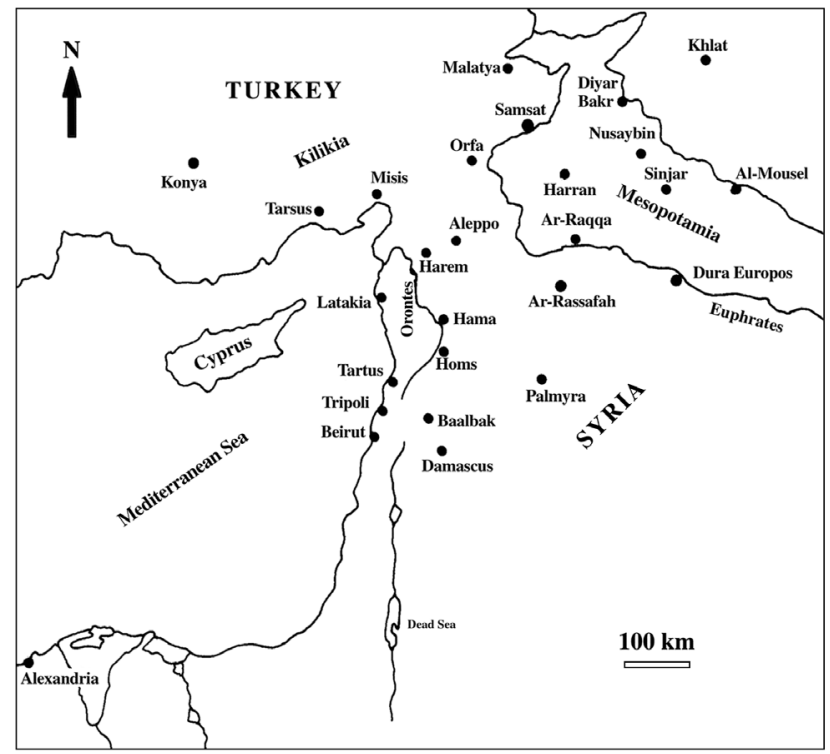

Fig. A.1. Major cities affected by the historical earthquakes in Syria and the surroundings. 
Sarakeb (town): southeast of Idleb.

Sarepta: see Sarfand.

Sarfand (village and archaeological site):

Sarepta, Lebanese littoral.

Sarghaya (town): northwest of Damascus.

Sarmada (village): north of Idleb, Northwestern Syria.

Sarmeen (village): $8 \mathrm{~km}$ southeast of Idleb.

Sarugi (?): see Suruc.

Sebastia: see As-Samyra.

Seleucea: see Suaidiya.

Sepphoris (?): Palestine.

Sergiopolis: see Ar-Rassafah.

Sfuhen (village and archaeological site): Salfouhum?, west of Maarret Annooman.
Shamrin: see As-Samyra.

Shaqa (village): Triaris, Lebanese coast.

Sharqat (?): in Iraq.

Sicily: see Siqilliya.

Sidon: see Saida.

Sinjar (mountain): Northern Iraq.

Siqilliya, Sicily (island): Southern Italy.

Sis (town): in Kilikia, Southern Turkey.

Smyrna: see Izmir.

Soada: see As-Suweida.

Sur, Tyre (city): Tyre, southern Lebanese littoral. Suruc (?): Sarugi, between Harran and Orfa, Southern Turkey.

Suaidiya, Sweidiyeh (town): Seleucea, near Antioch.
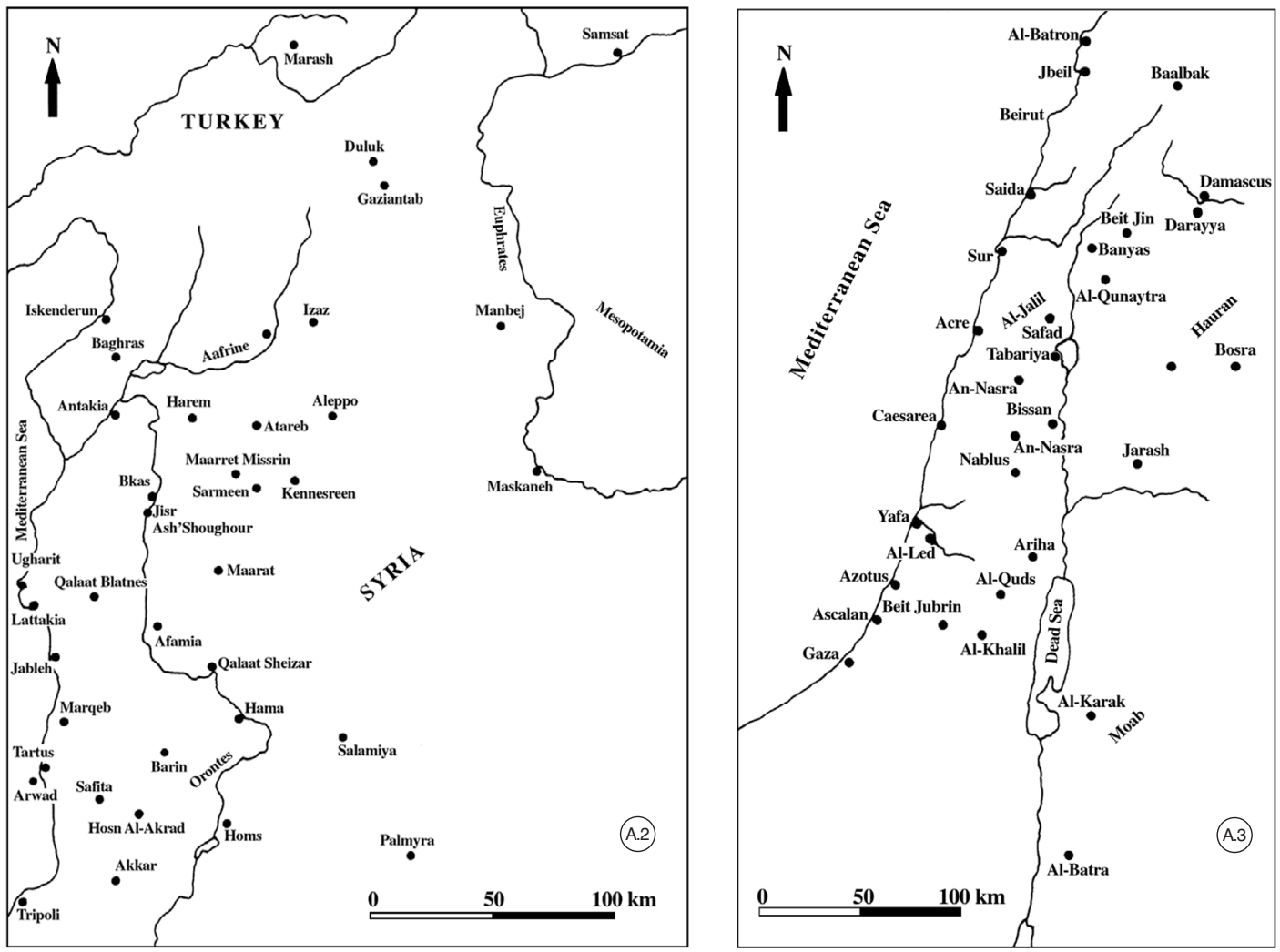

Fig. A.2. Localities affected by the historical earthquakes in Western and Northern Syria.

Fig. A.3. Localities affected by the historical earthquakes in and around Palestine. 
Sweidiyeh: see Suaidiya.

Tabariya, Tiberias (town): Northern Palestine. Tadmor, Palmyra (town and archaeological site): Tadmor, Central Syria.

Taftanaz (village): $15 \mathrm{~km}$ northeast of Idleb. Tarablus Ash-Sham, Tripoli (city): northern Lebanese littoral.

Tartus (city): Antaradus, Tortosa, Syrian littoral. Tarsus (town): Southern Turkey.

Tel Aviv: see Yafa.

Theopolis: see Antakia

Tiberias: see Tabariya.

Tinnis (village): NE Egypt.

Tortosa: see Tartus.

Triaris: see Shaqa.

Tripoli: see Tarablus Ash-Sham.

Tyre: see Sur.

Ugharit: see Ras Shamra.

Urfa: see Orfa.

Yabroud (town): Labruda, northeast of Damascus.

Yafa, Jaffa, Tel Aviv (city): Japho, Palestinian littoral.

Zabadani (town): northwest of Damascus.

Zahleh (city): Eastern Lebanon.

Zefat: see Safad.

Zerba, Zirbeh (village): SW of Aleppo, NW of Syria.

Zirbeh: see Zerba.

(For location of the most of these localities, see figs. A.1., A.2. and A.3.).

\section{REFERENCES}

Bibliographical list of all types of historical and modern references.

\section{Abbreviations}

$\mathrm{AE}=$ Archives Etrangères (in $\mathrm{AN})$.

$\mathrm{AN}=$ Archives Nationales, Paris.

BBA = Başbakanlik Arşivi, Istanbul.

$\mathrm{BL}=$ British Library, London .

Bodleian $=$ Bodleian Library, Oxford .

$\mathrm{CFHB}=$ Corpus fontium historiae Byzantinae

CSCO Arab. = Corpus Scriptorum Christianorum Orientalium, Scriptores Arabici.

CSCO Syr. = Corpus Scriptorum Christianorum Orientalium, Scriptores Syri.

$\mathrm{CSHB}=$ Corpus Scriptorum Historiae Byzantinae

$\mathrm{FO}=$ Foreign Office archives, Public Record Office, London . Leiden $=$ Bibliotheek der Rijksuniversiteit te Leiden .
$\mathrm{MD}=$ Mühimme Defteri (in BBA)

MMD = Maliyeden Müdevver Defterler (in BBA).

MGH, AA = Monumenta Germaniae Historica, Auctores Antiquissimi.

PG = Patrologiae cursus completus, series Graeca.

$\mathrm{SP}=$ State Papers (in FO)

Sources

'AbD Al-Basit, Nail Al-amal fi Dhail Al-Duwal, Bodleian Ms. Huntington 610.

'AbD Al-LATIF, Kitab Al-Ifada, facsimile edited and translated by K.H. ZAND, J.A. VIDEAN and I.E. VIDEAN, The Eastern Key, London 1965; also translated by SILVESTRE DE SACY, Relation de l'Egypte, Paris 1810.

ABU'L-FADA'Il, Tarikh Mansuri, facsimile edited by P.A. GRYAZEvitch, Moscow 1960.

ABU'L-FADA'IL, Al-Tarikh Al-Mansuri, facsimile edited by ABu Al-EID Doudou, Damascus 1982.

ABu Al-FIDA, E., Al-Mukhtasar fi Akhbar Al-Bashar, vols. 2-4, Dar Al-kitab Al-Lubnani, Beirut 1970.

ABu Al-Faraj (Bar Hebraeus), Chronography, translated by E.A.W. Budge, London 1932.

Abu Shama, Al-Raudhtein fi Akhbar Al-Dawlatein, edited by Muhammad Hilmi Muhammad Ahmad, 2 vols., Cairo 1956-1962.

ABu Shama, Dhail 'ala Al-Raudatain, edited by M. ZAHID Al-KAUTHARI, Cairo 1947.

Agapius of Menbi, Kitab Al-Unwan, edited by A. VasilieV, Patrologia Orientalis, VIII, Fasc. 3, Paris 1921.

Agathias, in Patrologie Grecque (PG), edited by J.P. Migne, 88, col. 1359, 1360 .

Agathias, Historiae, edited by R. Keydell, CFHB 2, Berlin 1967; translated by J.D. FRENDO, The Histories, Berlin and New-York 1975.

AL-'Aini, Iqd Al-Juman fi Tarikh ahl Al-Zaman, Paris Ms. Arabe $1543(621-79 \mathrm{H})$ and $1544(799-832 \mathrm{H})$.

Al-AsQAlani, Ibn Hajar, Anbaa' Al-Ghamer bi A'nbaa' AlOumer, edited by HasAn HABASHI, Cairo 1969-1972.

Al-Assadi, KH. (1984): Ahiyaa Halab wa Asswaqouha, Ministry of Education (Pub.), Damascus.

AlBert Milioli, Cronica Imperatorum, Mon. German Hist. Ss. vol. 31

Al-Boustani, B., Dairet Al-Maaref (Arab Encyclopedia), vol. 9, Beirut 1887, 239-242.

Al-BudaYri Al-HalaK, A, Hawadith Dimashq Al-Yawmiyya bayn 1741 wa 1762, edited by A.I. KARIM, Cairo 1959.

AL-DA'UDI, continuator of Al-Suyuti, in Kashf Al-Salsala, 62-64; also edited by AL-HAFIZ, 1982.

Al-DawadARI, Abu Bakr Ibn Aybak, Kanz Al-Durar wa Jamea Al-Ghurar, Cairo 1972.

Al-DHAHABI, Tarikh Al-Islam wa-Tabaqat Mashahir Al-Islam, edited by H.D. Al-QADSI, V, Cairo no date (?1369/1950).

Al-DHAHABI, Kitab Al-'ibar fi Khabar Man Ghabar, edited by S. MunAJJID, 5 vols., Kuwait 1960-1966.

Al-Dwyhy, Astafanos, Tarikh Al-Azmineh, Al-Mashreq Journal, vol. 44, Beirut 1951.

AL-GHAZI, K.A. (N.D): The seismicity in Damascus region, Al-Mashreq Journal, vol. 6.

Al-GHazzI, Kamil, Nahr Al-thahab fi Tarikh Halap, 3 vols., Maronian Publisher, Aleppo 1926.

Al-Hamawi, Yaqut, see Yaqut Al-Hamawi. 
Al-Hamawi, Muhammad Ibn Ali (1963): Al-Tarikh AlMansouri, Moscow.

Al-Hamawi, Muhammad Ibn Ali, Mukhtasar Siyar AlAwail wa Al-Muluk wa Wasilat Al-Abd Al-Mamluk, Bibliotheque Nationale, Ms. Ar. 1507, 177a.

Al-Isfahani, Kitab Ta'rikh Sani Muluk Al-Ard wa'l-Anbiya, edited by GoTTWALD, Leipzig 1848 .

Al-Isfahani, Hamza, Tarikh Sini Muluk Al-Ard wa Al-Anbiya, Berlin 1921.

AL-JALABI, D., Ikhtiar Zoubdet Al-Athar Al-Jaliya fil ' $L$ Hawadith Al-Ardiya, Al-Najaf 1974.

Al-MAQRIZI, Itti'az, Al-Hunafa fi Akhbar Al-A'imma Al-Fatimiyyin Al-Khulafa, edited by J. SHAYYaL, 3 vols., Cairo 1967-1973.

AL-MAQRIZI (1970-1973): Al-Suluk Li-maarifat Dual Al-Mu$l u k$, edited by MouHAMmed Mustafa ZIYADAH, voll. 12, Cairo 1939-1958; edited by SA'ID ABD AL-FATTAH Ashour, voll. 3-4, Cairo.

Al-Mashreq Journal, Damascus.

AL-NABLSI, Abd Al-Ghani, Manuscript (see AL-HAFIZ).

Al-SaKhawi, Al-Dau Al-lami' Li-ahl Al-qarn Al-tasi', 12 vols., Cairo 1934-1936.

Al-SaYrafi, Ali Ibn Dawood, Nuzhet Al-nufus wa Al-Abdan fi Tawarikh Al-Zaman, edited by HASAN HABASHI, Cairo 1973.

Al-Shinaby, A., Al-Ghouras Al-Hissan fi Twarikh Hawadeth Al-Azman, Egypt 1900.

AL-SuYuTI, Jalal Ed-Din, Kashf Al-Salsala an Wasf Al-Zalzala, edited by A. SAADANI, Fez 1971; French translation by S. AL-NAJJAR, Cahiers du Centre Universitaire de la Recherche Scientifique, Rabat 1974.

Al-SuYuTI, Jalal Ed-Din, Kashf Al-Salsala an Wasf Al-Zalzala (Al-Dar Library), edited by A.A. AL-FrYOUAI, Al-MadineH Al-Mounawra 1984.

Al-TABAKH Al-Halabi, Ragheb, Mouthakarat Tarikhieh Lemadinet Halap, 3 vols., Aleppo 1925.

Al-TAвAKH Al-HaLABI, Ragheb, Aalam Al-Noubala'a bi Tarikh Halab Al-Shahba'a, Aleppo.

Al-TABBAKH, Muhammad (1923): Ilam Al-Nubala, I, Aleppo, 205.

Al-TABARI, M. Ibn Jarir, Tarikh Al-Russol wa Al-Muluk, edited J.M. DE GOERJE, 3 vols. in 15, Leiden 1879-1901.

Al-TABARI, M. Ibn Jarir, Tarikh Al-Oumam wa Al-Mouluk, vol. 8, Cairo 1939.

Al-TABARI, M. Ibn Jarir, Tarikh Al-Russol wa Al-Muluk, edited by MouHAmmed ABUl-FAdHel IBRAHIM, voll. 110, Cairo 1960-1969.

Al-'Ulami, Al-Uns Al-Jalil Bi-tarikh Al-Quds wa 'l-Khalil, Cairo 1283/1866; abr. translated by J. SAuvaIRE, Histoir de Jerusalem et d'Hebron, Paris 1876; also 2 vols., Najaf 1388/1968.

Al-'Umari, Y. Al-Khatib, Ghayat Al-Masary fi Tarikh AlMahasen, Bagdad 1917.

Al-'Umari, Y. Al-Khatib, Ghraeb Al-Athar fi Hawadith Rouba Al-Karn Al-Thaleth Ashar, Mosel 1940.

Al-'Umari, Y. Al-Khatib, Mouniet Al-Oudabaa fi Tarikh Al-Mosel Al-Hadbaa, Mosel 1955.

Al-'UMARI, Y. Al-Khatib, Al-Athar Al-Jaliya fi'l-hawadith Al-Ardhiya, Ms. Iraqi Academy, Baghdad, also BL Or. 6300 .

Al-YA'Qubi, Tarikh, edited by T. Houstsma, 2 vols., Leiden 1883.

AL-YA'QUBI, Tarikh Al-Ya'qubi, voll. 1-2, Beirut 1960.
AnASTASE LE BIBLIOTHÉCAIRE, Histoire Ecclésiastique (Byzantin IX).

Annales 5689, Annales Terrae Sanctae, Bibliotèque Nationale de France, Paris, Fond Latin, no. 5689, Extr. Archives de 1'Orient Latin, vol. 2.

Annales de Terre Sainte, edited by G. RAYNAUD and R. RoHRICHT, Archives de l'Orient Latin, vol. 2b, 1884.

AnONYMous, Manah Al-Rabaniyya, Paris Ms. Arab. 1536.

ANONYMOUs, Chronicum, CSCO 56, 254-255.

ANONYMous PILGRIM, in Queen's College Oxford, Ms. 357, fol. 33ro.; also BL Ms. Haerleian 2333, fol. 30ro.

Archives Historiques Ch. Comm. Marseille, AA/340/ 1759-60.

ARChives NATIONALES (ANF), Affaires Etrangères (AE). (Bi/978 ‘Acre'), (Bi/973 ‘Aleppo'), (Cor. Pol., Turquie voll. 193, 194), (Libraries \& Archives), Paris.

ARChives NATIONALES (ANF), Affaires Etrangères (AE), vol. 26, 177-181, (Libraries \& Archives), Paris.

ATsIz, C.N. (1961): Osmanli Tarihine ait Takvimler, Istanbul.

BAETHGEn, F., Fragmente Syrischer und Arabischer Historiker. Abbandlungen f. die Kunde des Morgenlandes, VIII/3, Leipzig 1884

Bar Hebraeus, Girgis Abu Al-Faraj, Chronography, edited by P. Beduan, Gregorii Bahebraei Chronicon Syriacum, Paris 1890; translated by E.A.W. BudGe, The chronography of Gregory Abul-Faraj, London 1932.

Barletta Ms. in KOHLER (1900-1901).

Başbakanlik Osmanli Arşıvi (BBA), Mühimme Defteri (MD), (7.797), (Libraries \& Archives), Istanbul.

BaşBAKANLIK OSManli Arşıvi (BBA), Cevdet-Maliye (CM), (27741), (Libraries \& Archives), Istanbul.

BAŞBAKANLIK OSMANLI ARŞIVI (BBA), Maliyeden Müdevver Defterler (MMD), (3609.570), (Libraries \& Archives), Istanbul.

BEN ZVI (Editor), Edut Bi-Jhossef, Daron 40, Jerusalem 1933.

BibliotheEk RiJKsuniversiteIT (BRG), (Ms., no. 997, 9091), (Libraries \& Archives), Gnt.

BibliotheK Vadiana (BV), (Ms., no. S. 66d, p. 40), (Libraries \& Archives), St. Gall.

Broughton, Th.R.SH. (1935): Some non-colonial coloni of Augustus, Trans. Proc. Am. Philol. Assoc., 66, 18-24.

Broughton, Th.R.SH. (1938): An Economic Survey of Ancient Roma (The Johns Hopkins Press, Baltimore), vol. IV.

BÜCHElER, F. (1882): Coniectanea, Kleine Schriften, II, Leipzig-Berlin 1927, 444-463.

CAETANI, L. (1913-1923): Chronographia Islamica ossia Riassunto Chronologico della Storia di Tutti i Popoli Musulmani, 5 vols., Paris.

CAmeron Averil (1970): Agathias, Oxford

Cedrenus, Georgios, Histoir (XI Byzantin) in PG, edited by J.P. Migne, col. 569, 719.

Cedrenus, Georgius, Synopsis Historiarum, edited by I. BEKKER, Bonn 1838-1839.

Chandler, Tertius (1964): Date of the earthquake at Ugharit, J. Syria, XLI, 81-182.

Cevdet, 1309/1893, Cevdet tarhi, Istanbul.

Chronicle of $724=$ Chronicon Miscellaneum ad A.D. 724 Pertinens, edited by E.W.Brooks, in Chronica minora, II, CSCO 3 Syr. 3, Louvain 1960 (repr.), 77-155; Latin translation by J.B. СНАвот, CSCO 4 Syr. 4, Louvain 1960 (repr.), 61-119.

Chronicle of $819=$ Chronicon Anonymum ad A.D. 819 Pertinens, edited by A. BARSAUM, CSCO 81 Syr. 36, Lou- 
vain, 1953 (repr.), 3-22; Latin translation by J.-B. Снавот, CSCO 109 Syr. 56, Louvain 1937, 1-16.

Chronicle of $846=$ Chronicon A.D.846 pertinens, edited by E.W. BRooKs, in Chronica minora, II, CSCO 3 Syr. 3, Louvain 1960 (repr.), 157-238; Latin translation by J.B. СНАВОТ.

Chronicle of $1234=$ Chronicon ad Annum Christi 1234 Pertinens, edited by J.B. СНАвот, 2 vols., CSCO 81-82 Syr. 36-37, Louvain 1953 (repr.); Latin translation of Part I by J.B. Снавот, CSCO 109 Syr. 56, Louvain 1937; French translation of part II by A. ABOUNA, CSCO 354 Syr. 154, Louvain, 1974.

Chronicon Edessenum, edited by I. GuIDI, in Chronica minora, I, CSCO 1 Syr. 1, Louvain 1960 (repr.), 1-13; Latin translation by I. GUIDI, CSCO 2 Syr. 2, Louvain 1955 (repr.), 1-11.

Chronicon Maroniticum, edited by E.W. BROOKs, in Chronica minora II, CSCO 3 Syr. 3, Louvain 1960 (repr.), 4374; Latin translation by J.-B. Chabot, CSCO 4 Syr. 4, Louvain 1960 (repr.), 37-57.

Chronicon Pseudo-Dionysus of Tell-Mahre, Incerti Auctoris Chronicon Pseudo-Dionysianum Vulgo Dictum, edited by J.B. Снавот, CSCO, vol. 121, Scripores Syri, no. 66, Louvain 1949.

Chronique de Terre Sainte, 1131-1224, in Gestes des Chiprois, edited by G. RaYnaud, Publ. Soc. de l'Orient Lat., vol. 5, Paris 1887 (repr. Osnabruck 1968).

Chronography, edited by BAR HeBraeus, II, 144.

Clementoni, G. (1989): Tiberio e il Problema della Protezione Civile, in SORDI (1989a), 167-183.

Consular Archives: Foreign Office. London (FO 195/ 39.1796. Aleppo. Istanbul. Alexandria: FO, 78/110112.1822-3 Aleppo. Istanbul also FO 195/112: also for other years under Levant); India Office Records. London (IO SP 105/140.1822-4. Aleppo. Antioch. Suedia; also for other years); Archives Nationales, Paris (AN B1/1042/169204,1822 Aleppo, Saida, Levant; also for other years).

DAHMAN, M.A. (Editor) (1948): Zalzal sanat 1173, AlMashriq, 42, 333-337.

Dahman, M.A. (1982): Fi Rihab Dimashq (published by Dar Al-Fikr, Damascus), 194-216.

DARGon, G. (1974): Naissance d'une Capitale, Paris.

DARRouZÉs, J. (1954, 1957, 1958): Notes pour servir à 1'histoire de Chypre, Kypriakai Spoudai, vol. 17, 83102; vol. 20, 33-63; vol. 22, 224-250, Nicosia.

D'Arvieux, L., Mémoires du Chevalier d'Arvieux etc., 6 vols., Paris 1735.

Deutsche Presseforschung (BDP), Universitatsbibliothek, (Libraries \& Archives), Bremen-Zeitung, (Z. 20, no. 18, 1626.4.18)

DE VAuX, Vincent O.P., L'Archéologie et les Manuscrits de Mer Morte, British Academy, Oxford 1962.

Diaire des Pères Lazaristes de Tripoli (XIX), 1834.

Diaire des Pères Jésuites de Saida (XIX).

DIETRICH VON SCHACHTEM, in Deutshe Pilgerreisen nach dem Heiligen Lande, edited by R. RÖHRICHT and K. MEISNER, Berlin 1880 (new edition, Innsbruck 1900).

Dio Cassius Cocceianus, Historia Romana, Xiphilini Epitome, edited by U.P. Boissevain, Berlin 1895-1931; Dio's Roman History, edited by E. CARY, London-Cambridge (Mass.) 1914-27; The Roman History: the Region of Augustus, translated by I. SCOTT-KILVERT, Harmondsworth 1987.
Downey, G. (1938a): Seleucid chronology in Malalas, Am. J. Archaeol., 42, 106-20.

Downey, G. (1951): Nizam Al-Miyah fi Antakia fi Al-Ussor Al-Kadimah, translated by G. HADDAD, Journal of AlHawlyat Al-Atharia As-Souria I, Part II, Damascus, 281-283.

Downey, G. (1961): A History of Antioch in Syria, Princeton.

Elias of Nisibis, Opus Chronologicum, I, edited by E.W. BRooKs, CSCO 62 Syr. 21; Latin translation by E.W. Brooks, CSCO 63 Syr. 23, Paris 1910.

ERnoul, Chronique d'Ernoul et de Bernard le Trésorier, edited by MAS LATRIE, Paris 1871.

ERPENIUS, Historia Sarracernorum, translated by GIRGIS IBN AL-MANSUR, Leyde 1625.

Eusèbe, Histoir de Ecclésiastique (Byzantin V, dans Patrologie Grecque).

EusÈBe, Les Martyrs de Palestine.

Eusebius, Chronicon, edited by R. Helm, GSC 47, Berlin 1956.

Eusebius, I Martiri della Palestina, edited by G. DEL ToN, Scrinium Patristicum Lateranense, Roma 1964.

EusEbIUs, Praeparatio Evangelica, edited by G. Dindorf, Leipzig 1867.

EUTYCHIUS, see IBN BATRIQ.

EVAGRIUS SCHOLASTICUS, Historia Ecclesiastica, edited by J. BideZ and L. PARMEnTIER, London 1898 (repr. Amsterdam 1964).

Evens, S. (1784): Journal Kept on a Journey from Bassora to Otranto, Hrsham.

FIEY, J.M., Assyrie Chretienne, vol. 2, Impremerie Catholique, Beyrouth 1965.

FINDIKLI, Mür'it-tavanli, Bayzit Library Ms. F. 429, Istanbul.

Foster, R. (1902): De Libanio, Pausania, Templo Apollinis Delphico, Album gratultorium in honorem H. van Herwerden, Utrecht, 45-54.

Fragmenta Historica Tusculana, edited by A. MAI, 18081826.

Francesco Amadi, Chroniques d'Amadi et de Strambaldi, Chronique d'Amadi, edited by Mas Latrie, Coll. de doc. inedit. sur 1'Hist. de France, vol. 1, Paris.

Gazett de France (PGF), (1778.8.10, 9.11), (Press), Paris.

GenNADIUS, De Viribus Illustribus, edited by W. HERDING, Leipzig 1879 (repr. 1924).

GEOFFREY OF DONJON, Letter in MAYER (1972).

George the Monk, Chronicle, edited by C. DE Boor, BT, 2 vols., Leipzig 1904.

Georgius Cedrenus, see Cedrenus.

Georgius Monachus, see George the Monk.

Georgius Syncellus, see SynCEllus.

GIL, M. (1992): A History of Palestine, Cambridge, 634-1099.

Giovanni Lido, De Magistratibus Romanis, CSHB, 246247, Bonnae 1837.

Grosdidier de Matons, J., Romanos le Mélode, Hymnes V, Paris 1981.

Grumel, V. (1958): Traité d'Études Byzantines: la Chronologie, Paris.

GlyKas, Michael, see MichaEl GlyKas.

GuILlAuME DE TYRE (XII), Histoire, livre 20, chap. 18 (ouvrage écrit en latin, traduit et continué après lui sous les titres de Chroniques d'Eracles et d'Ernoul).

GüZELBEY, C. and H.YeKTIN (1970): Gaziantep Şer'i Mahkeme Sicillerinden Örnekler, vol. 140, Gaziantep, 57-58.

HadDAD, G. (1951) Anaser Al-Sukkan fi Antakia fi Al-Asr 
Al-Helnesti (The journal of Al-Hawlyat Al-Atharia AsSouria), 1, Part I, Damascus, p. 126.

Hakim Memet, Vakayi Name (I), Ms. Bagdad Kosku 231, Topkapi Sarrayi Library, Istanbul.

Hammer, J. von, Geschichte des Osmanischen Reiches, 10 vols., Pest.

Hethum of Gor'igos, Table Chronologique, Rec. Hist. Croisades. Arm., vol. 1.

Hethum Patmic, Chronicle, in Hakobyan (1956, p. 61).

Honigmann, E. (1952): Á propos de Pompéiopolis de «Mysie», Byzantion 22, 301-304.

HroznY, B. (1932): Les ionien à Ras Shamra, Arch. Or., IV, 169-178.

IBN Al-ATHIR, Ezz Ad-Din, Al-Kamil fi Al-Tarikh (Dar Sader), voll. 8, 9, 10, 11, 12, Beirut 1982 .

IBN Al-AthIR, Ezz Ad-Din, Al-Kamil fi Al-Tarikh, edited by C.J. TORNBERG, Leiden 1851-1876.

IBN Al-Furat, Tarikh Al-Duwal wa ' $l$-Muluk, edited by HASSAN AL-SHAMMA, vol. IV/I-V/I, Basra 1969.

IBN AL-IMAD, Al-Hanbali, Shatharat az-Zahab fi Akhbar men Zahab, Beirut.

IBN AL-JAWZI, Ajaib, Arabes 1567, 26a.

IBN Al-QAlanisi, Hamzah Ibn Assad, Tarikh Dimashq, edited by S. ZAKKAR, Damascus 1983.

IBN Al-SHinnA, Raudat Al-Munazir fi Akhbar Al-Awa'il wa'l-Awakhir, British Library Ms., Or., Add. 23,336.

IBN AL-SHIHNA, Raudat Al-Munazir, on the margins of Ibn Al-Athir, edited by BULAQ, vols. VII-IX, Cairo 1874.

IBN AL-WARDI, Omar, Tarikh Ibn Al-Wardi, voll. 1-2, Cairo 1879.

IBN BATRIQ, Al-Ta'rikh Al-Majmu' ala Al-Tahqiq wa'l-Tasdiq (Eutychii Patriachae Alexandrini Annales-Pars Prior), edited by L. CHEIKHo, CSCO Arab., Series tertia, vol. 6, Beyrout-Paris 1906.

IBN HABIB, Tadhkirat Al-Nabih, edited by M.M. AmIN, 3 vols., Cairo 1976-1986.

IBN HAJAR, see Al-Asqalani.

IBN IYAS, Mohammad Ibn Ahmad, Bada'i' Al-Zuhur fi waqa' $i$ ' Al-Duhur, edited by P. KAHLE and M. MostafA, 5 vols., Cairo and Wiesbaden 1960-1975. Partly translated by G. WIET, Histoire des Mamlouks Circassiens, II, Cairo 1945; and G. Wiet, Journal d'un Bourgeois du Caire, 2 vols., Paris 1955, 1960.

IBN JARIR AL-TABARI, M., see AL-TABARI.

IBN JUBAIR, The Travels of Ibn Jubayr, edited by W. WRIGHT; 2nd edition by J.M. DE GoEJE, Gibb Memorial Series, vol. 5, London 1907.

IBN KATHIR, Al-Bidaya wa Al-Nihaya fi ' l-Tarikh, 13 vols., Cairo 1351-1358/1932-1939.

IBN KATHIR Al-DimASHQI, Al-Bidaya wa Al-Nihaya, voll. 11, 12, 13, Beirut 1988.

IBN MANKALI, Al-Ahkam Al-Mulukiyya, vol. 37, quoted in TAHER (1979, p. 125).

IBn QAdi SHuhba, Al-Kawakib Al-Duriyya fi ' $l$-Sirat AlNuriyya, edited by M. ZAYIDH, Beirut 1971.

IBn Shaddad, Al-A'laq Al-Khatira fi Dhikr Umara' AshSham wa'l-Jazira, edited by D. Sourdel, Damascus 1953.

IbN ShaKIR Al-Kutubi, Uyun Al-Tawarikh, Bibliotheque Nationale Ms. Arab. 1588, 88a.

IBN TAGRi BIRDI, Al-Nujum Al-Zahira fi Muluk Misr wa'lQahira, Cairo 1932.

IBN Tulun, Mufakaat Al-Khillan fi Hawadith Al-Zaman, edited by M. Mostafa, 2 vols., Cairo 1962,1964.

IBN WASIL, Mufarrij Al-Kurub fi Akhbar Bani Ayyub, edited by M. Shayyal, vol. III, Cairo 1962.

IOHANNES MALALAS, see MALALAS.

IOHANNES ZONARAS, see ZONARAS.

JACOB of EDESSA, Chronicle, edited by E.W. BRooKs, in Chronica minora III, CSCO 5 Syr. 5, Louvain 1961 (repr.), 261-330; Latin translation by E.W. BRooKs, III, CSCO 6 Syr. 6, Louvain 1960 (repr.), 197-258; English translation by E.W. BRooKs, The Chronological Canon of James of Edessa, Zeitschrift der deutschen morgenlandischen Gesellschaft, 53 (1899), 261-327, 550; 54 (1900), 100-102.

JALFAQ, B., Évêque de Saida-Lettres publiées dans les Nouvelles (Riçalat) de l'Abbaye de Mar Mukhallès près Saida.

JEFFREYS, E., M. JEFFREYS and R. SCOTT (Translators) (1986): The Chronicle of John Malalas, Sydney, N.S.W.

Joshua the Stylite, The Chronique of Joshua the Stylite composed in Syriac, A.D. 507, translated by DE WRIGHT, Cambridge 1882.

JOHN OF EPHESUs, Ecclesiastical History, Fragments of Part II, edited by J.P.N. LAND, Anecdota Syriaca, 2, Leiden 1868, 289-329; Latin translation by W.J. VAN DOUwEN and J.P.N. LAND, Ioannis Ephesini episcopi Commentarii de beatis orientalibus et Historiae ecclesiasticae fragmenta (Verhandelingen van de Kkoninklijke Akademie van Wetenschappen. Afdeeling Letterkunde, 18), Amsterdam 1889, 216-243; Part III, edited by E.W. BROOKS, CSCO 105 Syr. 54, Louvain 1935; Latin translation by E.W. BRoOKS, CSCO 106 Syr. 55, Louvain 1936.

JoHN OF NIKIU, The Chronicle of John Bishop of Nikiu, translated to English by R.H. CHARLES, 135-137, London 1916.

Journaux Contemporains des Événements.

KILISLI, Kadri (1932): Kilis Tarihi, Istanbul.

KoRTE, J. (1741): Jonas Kortens Reise nach Egypten dem Berg Libanon etc., Altona.

LANDESBIBLIOTHEK (LBS), (Libraries \& Archives), StuttgartZeitung (Allgem. G., qt. 407, 1626.5.1).

Leo Grammaticus, Chronographia, edited by I. BeKKer, CSHB, Bonn 1842

Les Gestes des Chyprois, Rec. Hist. Croisades. Arm., vol. 2.

L'Estoire d'Eracle, Rec. Hist. Croisades. Occ., vol. 2.

Liebeschuetz, J.H.W.G. (1972): Antioch: City and Imperial Administration in the Later Roman Empire, Oxford.

LIGORIO PIRRO (1574-1577): Libro o Trattato di diversi terremoti, raccolti da diversi Autori per Pyrro Ligorio cittadino romano, mentre la città di Ferrara è stata percossa et ha tremato per un simile accidente del moto della terra, Archivio di Stato di Torino, Antichità romane, cod. 28.

Lusignano, S. (1950): Descripion de Toute l'Isle de Chypre etc., translated by G. CHAUdière, Paris.

Malalas, IoHannes (1831): Chronographia, edited by L. DiNDORF, CSHB, Bonn 1831; translated by E. JEFFREYS, M. JEFFreys and R. ScotT, The Chronicle, Sydney, N.S.W. 1986.

Marcellinus Comes (1894): Chronicon, edited by TH. Mommsen, MGH, AA 11, Chronica minora, vol. 2, Berlin, 37-104.

MARINO SANUTO, THE ELDER, Liber secretorum (Secrets for the Crusaders) or Gesta Dei per Francos, book III/XI, ch. 1, Hannover 1611. 
McGing, B.C. (1986): The Foreign Policy of Mithridates VI Eupator King of Pontus, Leiden.

Mercure DE France (PMdF), (1726.10, p. 2349), (Press), Paris.

Michael Glykas, Annales, edited by J.P. Migne, PG 158, Paris 1866.

MichaEl THE SyRIAn, Chronicle, translated by J.-B. Chabot, 4 vols., Paris 1899.

Ministère des AfFAIREs ETRANGÈREs, Centre des Archives Diplomatiques de Nantes (AMAE CADN), (CCC, Turquie vol. 14, Lattaquie, entry dated 1822.8.28), Nantes.

MuHAMmed AL-TABAKH, see Al-TABAKH.

Mukhtar Basha, Muhamed, Al-Tawfiqat Al-Ilhamyeh, Boulaq 1893.

MüNZER, TH. (1930): s.v. Marcius 92, RE 14.2, cols. 15841585.

NASIR-I-KHusRau, Sefer Nameh, Relation du Voyage de Nassiri Khusrau en Syria, en Palestine, et Egypte, en Arabe ..., Charles Schefer, Paris 1881, 17-18.

Nicephorus Callistus, Historia Ayntomo, edited by C. DE BoR, BT, Leipzig 1880

NicePhORUS PATRIARCHA, Short History, edited by C. MANGO, Washigton D.C. 1990

Nicetas Choniates Acominatos, Historia Chronicon, edited by I. BeKKER, Corp. Script. Hist. Byz., Bonn 1835.

OBerhummer, E., Die Insel Cypern. Eine Landeskunde auf historischer Grundlage, edited by TH. ACKERMAN, München 1903, 139-146.

OBERMEYER, J., Die Landschaft Babilonien im Zeitalter des Talmuds und des Gaonats, Frankfort a.M 1929.

OliviER, G.A. (1807): Voyage dans l'Empire Othoman, L'Egypte et la Perse, 3 vols., Paris.

OpPENHEIMER, A. (1983): Babylonia Judaica in the Talmudic Period, Wiesbaden.

Oracula Sibyllina, edited by A. KURFESS, München 1951; edited and translated by H.N. BATE, Sibylline oracles (books III-V), London 1918.

Orosius Paulus, Historiarum Adversus Paganos Libri VIII, edited by A. LIPPOLD, Milano 1976.

PANZAC, D. (1985): La Peste dans l'Empire Ottoman, 17001850 , Louvain.

PAYne SMITH, R. (Editor) (1879): Thesaurus Syriacus, Oxford.

PhILIP OF Plessis (1972): Letter in MAYER.

Philostratus the Athenian, Vita Apolloni, edited by C.L. KAYSER, I, Leipzig 1870; translated by F.C. CONYBEARE, The Life of Apollonius of Tyana, London 1912; translated by J.S. Phillimore, Philostratus in Hinour of Apollonius of Tyana, Oxford 1912; translated by C.P. Eells, Life and times of Apollonius of Tyana, Stanford 1923.

Press Reports: Varius: most important. Istanbul (Levant Herald, Stanboul, Neologos, Ikdam, Sabah). Izmir (Amaltheia, Courier de Symrne). Paris (Moniteur, Journal des Debats, Nouvelles Missions du Levant).

Pococke, R.A. (1743-1745): A Description of the East etc., 2 vols., Bowyer, London.

Procopius of CAesarea, Anecdota, in Opera omnia, edited by J. HAURY and G. WIRTH, III, Liepzig 1953; translated by G.A. Williamson, Secret history, London, 1990.

Procopius of Caesarea, Bella, in Opera omnia, edited by J. HAURY and G. WIRTH, I-II, Liepzig 1952-1953.

Procopius of Caesarea, De Aedificiis, in Opera omnia, edited by J. HAurY and G. WIRTH, IV, Liepzig 1954.

RAFEQ, A.K. (no date): The provance of Damascus.
Ralph of Coggeshall, Chronicon Anglicanum, edited by J. Stevenson, Rolls Ser., vol. 66.

Res gestae Divi Augusti, edited by P.A. Brunt and J.M. MOORE, Oxford 1967.

Rizzo, F.P. (1963): Le Fonti per la Storia della Conquista Pompeiana della Siria, Palermo.

RoBert, L. (1962): Villes d'Asie Mineure (2nd edition), Paris.

Robert of Auxerre, Chronicon, Mon. German. Hist. Ss. vol. 26; also edited by BouQuet, Rec. Hist. Gaule et de la France, vol. 18.

Runciman, S. SiR (1971): A History of the Crusades,Harmondsworth, 3 vols..

SAADEH, G. (1984): Al-Moukhtasar fi Tarikh Al-Lathiqieh (A Summary in the History of Lattakia), Lattakia.

SAADEH, S. (1982): Ugharit, Mu'assaset Al-Fikr lil'abhath we Al-Nasher (1st edition), Beirut.

Salimbene de Adam, Cronica, Mon. German. Hist. Ss., vol. 32 .

SCHAEFFER, C.F.A. (1948): Stratigraphie Comparée et Chronologie de l'Asie Occidentale (IIIe et Ile millénaires), (Oxford University Press, London).

SCHENK VON STAUfFENBERG, A. (1931): Die romische Kaisergeschichte bei Malalas, Stuttgart.

Sempad le Connétable, Chronique du Royaume de Petite Arménie, Cf KSA 6, p. 29 (Reports of Ksara Observatory).

SEVERUS of ANTIOCH, Homily 31, edited with French translation by M. BrIÈRE and F. GRAFFIN, Les Homiliae cathedrales de Sévère d'Antioche. Traduction syriaque de Jaques d'Edesse. Homélies XXVI à XXXI, PO 36/4= =170, Turnhout 1974, 106-31.

SibT Ibn AL-'AJAmi, Kunuz Al-Dhahab fi Tarikh Halab, translated by J. SAUVAGET, Matériaux pour servir à l'histoire de la ville d'Alep, Beirut 1950.

SiBT IBN Al-JAUZI, Mir'at Al-Zamn, vol. VIII, Hyderabad 1951.

Sibt IBN Al-Jawzi, A., Al-Mountazam fi Tarikh Al-Mouluk wa Al-Oumam, vols. 7, 8, 9, 10, Haydarabad 1938.

Sibt IBN Al-JAwZI, A., Al-Mountazam fi Tarikh Al-Mouluk wa Al-Oumam, British Library Ms. Or. 3004, $19 \mathrm{~b}$.

Socrates, Historia Ecclesiastica, edited by J.P. Migne, PG 67, Paris 1864.

Stein, E., Histoire du Bas-Empire II, edited by J.-R. PALANQUE, Bruges 1949.

Strabo, Geographica, edited by A. MeIneKe, Leipzig 1877; edited by G. Aujac and F. LASSERE, Paris 196689; edited by H.L. JoHnEs, The Geography of Strabo, London-Cambridge (Mass.) 1917-1928.

Strabon, Géographe Grec (a vécu de 58 à 21-25), Auteur de «Geographica».

Suetonius, C. Tranquillus, De Vita Caesarum, edited by H. AIlloud, Paris 1961-1964; translated by R. GRAVES, The twelve caesars, Harmondsworth 1989.

SynCEllus, Georgius, Chronographia, edited by G.B. NieBuHR, CSHB, Bonn 1829; edited by A.A. MosshaMMER, Leipzig 1984.

Tacitus, Publius Cornelius, Annales ab Excessu Divi Augusti, edited by E. KoESTERMANN, Leipzig 1971; translated by M. GRANT, The annals of imperial Rome, Harmondsworth 1989 .

The Book of the Wanderings of Felix Fabri (1480-83), vol. 9, London 1893 (repr. AMS, New York 1971).

The Great Chronographer, in Beitrage zur antiochenis- 
chen und zur kostantinopolitanischen Stadtchronik, edited by A. FREUND, Jena 1882, 38-53.

Theatrum Europeum, edited by J.P. ABELIN, 21 vols., Frankfurt 1617-1712.

Theophanes, Theophanis Chronographia, CSHB, vol. 26/i, Bonn 1839.

TheOPHANES, Chronographi, edited by C. DE Boor, Leipzig 1883-85 (repr. Hildesheim 1963).

Theophanes Continuatus, edited by I. BeKKer, CSHB, Bonn 1838.

TsugitaKA, S. (1988): The Syrian coastal town of Jabala: Its history and present situation, Studia Culturae Islamicae, 35 (Institute for the Study of Languages and Cultures of Asia and Africa, Tokyo).

Tusculum (Fragments of Tusculum), D'avant l'an 565, découvert par Angelo May, Fragment IV, in PG, edited by J.P. Migne, 85, coll. 1821-1824.

VAlle, Pietro della (1662-63): Viaggi di Pietro della Valle il Pellegrino etc., 4 vols., Roma.

Vita Symeonis Iunioris, edited by P. VAN DEN VEN, Brussels 1962-1970.

Vitaliano Donati, Giornal del Viaggio, Bibl. Reale Ms. 291, Torino.

Volney, C.F. (1787): Travels through Syria and Egypt in the Years 1783, 1784 and 1785, 2 vols., London.

Whitby, M. and M. (Translators) (1989): Chronicon Paschale 284-628 A.D., Liverpool.

Wilbrandus of OldenborG, Travels, edited by J.C.M. LAURENT, Peregrinatores medii aevi quatuor (2nd edition), Leipzig 1873, 161-191.

William of Nangis, Chronicon, Rec. Gaule et de la France, vol. 20.

WinnetT, F.V. and W.L. REED (1970): Ancient Records from North Arabia, Toronto.

YAARI, A. (1951): Sinai: 28.349, Jerusalem.

YAHYA IBN SAID, Histoire, edited and translated into French by I. KRATChKovsky and A. Vasiliev, Pat Orientalis, XVIII, Fasc. 5, Paris 1957.

YAHYA IBN SAID AL-ANTAKI, Dhayl ta'rikh Ibn Batriq, edited by L. CHeIKHo et al., CSCO Arab., Series tertia, vol. 7, Beirut-Paris.

YaquT Al-HamaWI, Mu'jam Al-Buldan, edited by WusteNFELD, 4 vols., Leipzig 1866-1873.

Yebamoth (from The Bobylonian Talmud), edited by I.W. SLOTKI, London 1936.

ZaCHARIAH OF Mitylene, The Syriac Chronicle, translated by F.J. Hamilton and E.W. Brooks, London 1899.

Zacharie le ScolastiQûe, Vie de Sévère d'Antioche, Patrologie Orientale (2nd edition), Graffin-Nau.

ZAKarayA, W. (1984) Jawla Athariya fi Baedh Al-Bilad AlShamiya, Dar Al-Fikr (Pub.), Damascus.

ZoNARAS, Iohannes, Epitome Historiarum Libri I-XII, edited by B.G. NIEBUHR, CSHB, Bonn, 1844; Epitome Historiarum Libri XIII-XVIII, edited by Th. BüTTNERWoBst, CSHB, Bonn 1897.

\section{Parametric catalogues}

ABOU KARAKI, N. (1987) : Synthèse et carte sismotectonique des pays de la bordure orientale de la Méditerranée : sismicité du systéme de failles du Jordain-Mer Morte, Thèse de Doctorat (Université Louis Pasteur, Strasbourg).
AL-HAKeEM, K. (1988): Studying of historical earthquakes activity in Syria, in Proceedings of the Workshop on Historical Seismicity of Central-Eastern Mediterranean Region, edited by C. Margottini and L. Serva, 27-29 Ottobre 1987, ENEA CRE Casaccia, Roma, 19-32.

AL-Sinawi, S.A. and H.A.A. GHALIB (1975): Historical seismicity of Iraq, Bull. Seismol. Soc. Am., 65 (5), 541-547.

Ambraseys, N.N. (1961): On the seismicity of South-West Asia: data from a XVth century Arabic manuscript, Rev. Etud. Calamités, 37, 18-30.

Ambraseys, N.N. (1962): A note on the chronology of Willis's list of earthquakes in Palestine and Syria, Bull. Seismol. Soc. Am., 52, 77-80.

Ambraseys, N.N. (1963): The seismicity of Cyprus, Publications of Imperial College, London.

AmbraseYs, N.N. (1965): The seismic history of Cyprus, Rev. Union Int. Secours, 3, 25-48.

Ambraseys, N.N. (1975): Studies in historical seismicity and tectonics, in Geodynamics Today (Royal Society, London), 7-16.

Ambraseys, N.N. (1978): Middle East: a reappraisal of the seismicity, Q. J. Eng. Geol., 11, 19-32.

AMIRAN, D.H.K. (1950-1951, 1952): A revised earthquake-catalogue of Palestine, Isr. Explor. J., 1, 223-246; 2, 48-62.

ANDREASYAN, H. (1970): Ermeni Kaynaklarindan Derlenmis Deprem Listesi, Yayinlanmamis, Prof. Dr. H. Soysal Arsivi, Istanbul.

BÅTH, M. (1979): Introduction to Seismology (2nd edition), Basel, Boston, Stuttgart, p. 139.

Ben-Menahem, A. (1979): Earthquake catalogue for the Middle East (92 B.C. to 1980 A.D.), Boll. Geofis. Teor. Appl., 21, 245-313.

Berloty, B. (1931) : Tremblements de terre et séismologie, Almanach de l'Imprime Catholique, 24-38.

Calvi, V.S. (1941): Erdbebenkatalog der Turkei und Einiger Benaehbarter Gebiete, Yayinlanmamis, Rep. No. 276, MTA Enstitüsü, Ankara.

ERgIN, K., U. GÜÇLÜ and Z. Uz (1967): A Catalogue of Earthquakes for Turkey and Surrounding Area (11 A.D. to 1964 A.D.), Technical University of Istanbul, Istanbul.

Galanopoulos, A.G. and N.D. Delibasis (1965): The seismic activity of the Cyprus Area (26 B.C.-1963 A.D.), in Proc. Athens Academy, 387-405.

Ganse, R.A. and J.B. NeLSON (1981): Catalogue of significant earthquakes (2000 B.C.-1979 A.D.), Rep. SE-27, World Data Center A for Solid Earth Geophysics, pp. 154.

IsmAIL, A. (1960): Near and local earthquakes of Helwan (1903-1950), Helwan Obs., 49, pp. 32.

KÁRNík, V. (1971): Seismicity of the European Area (D. Reidel Publishing Company, Dordrecht, Holland), 2.

LERSCH, Erdbeben-Chronik für die Zeit von 2362 v. Chr. bis 1897, Ms., Archives of the Zentralinstitut für Physik der Erd, Jena.

Lomnitz, C. (1974): Global tectonics and earthquake risk, Dev. Geotect., 5, Elsevier Sc. Publ. Com., p. 320.

Lyons, H.G. (1907): Earthquakes in Egypt, Survey Notes, Cairo, I (10), 277-86.

Maamoun, M. and A. Allam (1981): Neotectonics of Eastern Arabian region - Regional studies, Bull. Helwan Inst. Astron. Geophys., I, Ser. B, 173-235.

MeYers, H.M. and C.A. vON HAKE (1976): Earthquake data file summary, National Geophysical and Solar Terrestrial Data Center, Boulder, CO. 
MiLnE, J. (1911): Catalogue of destructive earthquakes A.D. 7 to A.D. 1899 , Report of the 81st Meeting of the British Association for the Advancement of Science, London, 694-740.

Morelli, C. (1942): Carta sismica dell'Albania, Reale Academia d'Italia, Commissione Italiana di Studio per i Problemi del Soccorso alle Popolazioni, 10, Firenze, p. 121.

Mouty, M. and M.R. SbeinAti (1988): Historical earthquake catalogue for Syria and adjacent areas, Atomic Energy Commission of Syria, Internal Rep., Damascus.

ÖCAL, N. (1961): Kurze Liste der Erdbeben in der Türkei bis $1800(I \geq I X)$, Ms., 2.

ÖCAL, N. (1968): Türkiyenin sismisitesi ve zelzele cografyasi, 1850-1960 Yiliari Için Zelzele Katalogu, Kandilli Rasathanesi Yayinlari No. 8, Istanbul.

PINAR, N. and E. LAHN (1952): Türkiye depremleri izahli kataloğu, Bayindirlik Bakanligi, Yapi ve Imar Isleri Reisligi Yayinlarindan, Ser. 6, Sayi 36, Ankara, p. 153.

Plassard, J. and B. KogoJ (1981): Seismicité du Liban: catalogue des séismes ressentis (3rd edition), Collection des Annales-Mémoires de l'Observatoire de Ksara, IV, Beirut.

POIRIER, J. and M. TAHER (1980): Historical seismicity in the Near and Middle East, North Africa, and Spain from Arabic documents (VIIth-XVIIIth century), Bull. Seismol. Soc. Am., 70, 2185-2201.

RigGS, H.H. (1905-1909): Monthly Earthquake Reports, Euphrates College Seism. Station, Harpoot.

Russell, P. (1760): An account of the late earthquake in Syria, Philos. Trans., 51, London, 529-534.

SchMidT, J.F. (1879): Studien üeber Erdbeben, Leipzig.

SCHмIDT, J.F. (1881): Studien über Vulkanen und Erdbeben (2nd edition), Leipzig.

Shalem, N. (1952): La seismicité au Levant, Bull. Res Counc. Isr., 2 (1), 1-16.

Shalem, N. (1954): The Red Sea and the Erythrean disturbances, in Congrès Géologique International, $C$., $R$., de la 19e session, Alger, 222-231.

Shalem, N. (1956) Seismicity and Erythrean disturbances in the Levant, Publ. BCIS, S.A., Tr. Sc. F. 19, 267-275.

Shalem, N. (1960): Seismicity in Palestine and neighboring areas (macroseismical investigation), Ms., 79.

Shebalin, N.V., V. KÁRníK and D. HADZIEVSKI (1974): Catalogue of earthquakes, Part I: 1901-1970; Part II: prior to 1901, UNESCO, Skopie.

Soysal, H., S. SipahiĞLU, D. KolÇAK and Y. AltinoK (1981): Türkiye ve çevresinin tarihsel deprem kataloğ $u$ (M.Ö. 2100-M.S. 1900), Tubitak, Matematik - Fiziki Ve Biyolojik Bilimler Arastirma Grubu, Project. No. TBAG 341, Istanbul.

TholOZAN, J.D. (1879): Sur les tremblements de terre qui ont eu lieu en Orient du VII au XVII siecle, Compte Rendus de l'Académie des Sciences de Frances, 88, 1063-1066.

Türkelli, N., A. NecioĞLU and A. Al-Amri (1990): Seismicity of the Eastern Mediterranean, in Proceedings of the Workshop on Historical Seismicity and Seismotectonics of the Mediterranean Region (Bektur, ed.), Istanbul, 37-129.

US CONGRESS (1888): Great Earthquakes (Washington D.C.), 1.

Willis, B. (1928): Earthquakes in the Holy Land, Bull. Seismol. Soc. Am., 18, California, 73-103.

WiLlis, B. (1933a): Earthquakes in the Holy Land: a correction, Bull. Seismol. Soc. Am., 23, 88-89.
WILLIS, B. (1933b): Earthquakes in the Holy Land: a correction, Science, $\mathbf{7 7}$, p. 351.

World Map of Natural Hazards (1978), Münchener Rückversicherungs-Gesellschaft, Munich, Federal Republic of Germany.

\section{Seismological compilations}

Al-GHouneim, A.Y. (no date): Asbab Al-Zlazel wa Houdutheha fi Al-Tourath Al-Arabi (Causes of Earthquakes and their Events in the Arabic Literature).

AL-HAFEZ, M.M. (1982): Nusus ghair manshura an al-zalazil men 914-1124 A.H./1508-1712 A.D., Bull. Etud. Orientales, 32-33, Damascus, 256-264.

Alonso-NúũEZ, J.-M. (1992): La Historia Universal de Pompeyo Trogo, Madrid.

Al-Sanawi, S. and H.A. Ghalib (1975): Historical seismicity of Iraq, Bull. Seismol. Soc. Am., 65, 541-547.

Ambraseys, N.N. (1961): On the seismicity of South-West Asia: data from a XV century Arabic manuscript, Rev. Etud. Calamités, 37, 18-37.

AmbraseYs, N.N. (1962): Data for the investigation of the seismic sea-waves in the Eastern Mediterranean, Bull. Seismol. Soc. Am., 52, 895-913.

AMBRASEYs, N.N. (1988) Engineering seismology, J. Earthquake Eng. Struct. Dyn., 17, 1-105.

Ambraseys, N.N. (1989): Temporary seismic quiescence: SE Turkey, Geophys. J., 96, 311-331.

AmBraseys, N.N. and C.F. FinKEL (1993): Material for the investigation of the seismicity of the Eastern Mediterranean region during the period 1690-1710, in Materials of the CEC Project 'Review of Historical Seismicity in Europe', edited by M. STUCCHI, CNR Milano, 1, 173-194.

Ambraseys, N.N. and C. Finkel (1995): The seismicity of Turkey and adjacent areas: a historical review (15001800), Muhittin Salih EREN Publ., Istanbul.

AMBRASEYS, N.N. and J.A. JAKSON (1998): Faulting associated with historical and recent earthquakes in Eastern Mediterranean region, Geophys. J. Int., 133, 390-406.

Ambraseys, N.N. and C.P. Melville (1995): Historical evidence of faulting in Eastern Anatolia and Northern Syria, Ann. Geofis., XXXVIII (3/4), 337-343.

AmbraseYs, N.N. and D. White (1997): The seismicity of the Eastern Mediterranean region 550-501 B.C.: a reappraisal, J. Earthquake Eng., 1 (4), 603-632.

Ambraseys, N.N., C.P. Melville and R.D. AdAms (1994): The Seismicity of Egypt, Arabia and the Red Sea: a Historical Review (Cambridge University Press).

Andreasyan, H. (1973): XIV ve XV. Yuzyil Turk Tarihine Ait Ufak Kronolojiler, Kolafanlar, Ist. Uni. Ede. Fak. Tarih Ens. Dergisi, Sayi 3, Istanbul.

ARINCI, R. (1945): Arzda ve Yerdumuzda Zelzele Bolgeleleri, Corumlu Mcmuasi, Corum Halkevi Yayini, Yil 4, Sayi 29, Corum.

BArbieri, G. (1970): Pompeo Macrino, Asinio Marcello, Bebio Macro e i Fasti Ostiensi del 115, Mélanges d'Archéologie et d'Histoire de l'Ècole Française de Rome, 82 (1), 263-78.

Baur, P.V.C. and M.I. RostovtzefF (1931): The Excavations at Dura-Europos, II, New Haven.

BERRYAT, J. (1761): Liste chronologique des éruptions de Volcans, des Tremblements de Terre etc., Collect. Académique, 6, Paris, 488-676. 
Besson, J. (1660): La Syrie Sainte ... Henault, Paris.

BlanCKENHORN, Max (1905): Die Erdbeben in Palästina und die erforschung künftiger, Zeitschrift des deutschen Palätinavereins, 28, part 1, 216-218.

Bonito, M. (1691): Terra tremante, o vero continuatione de' terremoti dalla Creatione del Mondo sino al tempo presente ..., Napoli 1691 (reprint, Sala Bolognese 1980).

BurnaRnd, Y. (1984): Terrae Motus, La documentation épigraphique sur les tremblements de terre dans l'Occident romain, in Tremblements de terr ...., 173-82.

Capelle, W. (1924): s.v. Erdbebenforschung, RE, Suppl. IV, coll. 344-374.

Catalogo epigrafi (1989) = Catalogo delle epigrafi latine riguardanti terremoti, in GUIDOBONI (1989), 135-68.

CAvasino, A. (1931a): Note sur catalogo dei terremoti distruttivi dal 1501 al 1929 nel bacino del Mediterraneo, 29-36, R. Acad. Nat. Lincei, Publ. della Com. It. per lo Studio delle Grandi Calamita, vol. II, Mem. Sci. Technol., Roma.

Cavasino, A. (1931b): Catalogo dei terremoti avertiti nel bacino del Mediterraneo del 1501 al 1929, 37-60, $R$. Acad. Nat. Lincei, Publ. della Com. It. per lo Studio delle Grandi Calamita, vol. II, Mem. Sci. Technol., Roma.

Collection AcadémiQue, Tome VI de la Partie Etranger et Premier, Tome de la Physique Experimentale Séparée.

FrancIs, I. (1947): Bizanz Kaynaklarina, Gore Orta Sark'ta Vukubulan Zelzeleler, 1st. Uni. Ed. Fak. Cog. B1. Doktora tezi, Ist. Uni. Kitapligi No. 1420.

Fuchs, C.W.C. (1886): Statistik der Erdbeben von 18651885, Sitzungsberichte d.M. Mathem.-Naturw. Ges., Bd. XCII, Heft. 3, 215-625, Vienna.

Gatier, P.L. (1984): Tremblements du sol et frissions des hommes, Trois séismes en Orient sous Anastase, in Tremblements de terre ...., 87-94.

GHawanmeH, Y. (1989): Earthquakes effects on Belad AlSham settlements, Paper presented at IVe Congrés sur I'Histoire et L'Archéologie de Jordanie, 30 May-4 June, Lyon.

Guidoboni, E. (Editor) (1989): I Terremoti Prima del Mille in Italia e nell'Area Mediterranea, Storia Archeologia Sismologia (ING, Roma-SGA, Bologna), pp. 768.

Guidoboni, E., A. Comastri and G. Traina (1994): Catalogue of Ancient Earthquakes in the Mediterranean Area up to the 10th Century (ING, Roma-SGA, Bologna), pp. 504.

Henry, M. (1985): Le témoignage de Libanius et les phénomènes séismiques du IVe siècle de notre ère, $E s$ sai d'Interprétation, Phoenix, 39, 36-61.

Hermann, A. (1962): s.v. Erdbeben, Reallexikon für Antike und christentum 5, cols. 1070-10113, (Contributions to the geology and palaeobiology of the Caribean and adjacent areas), Verhandlungen der Naturforschenden Gesellschaft in Basel 84, 101-52.

HoFf, K.E.A. von (1840): Chronik der Erdbeben und VulkanAusbrüche etc., Gesch. Überlief. Nachgew. Natürl. Veräender. Erdoberfläche, IV, Gotha.

KALLNER-AmiRAN, D. (1951): A revised earthquake catalogue of Palestine, Is. Explor. J., vol. I, 223-46; vol. II, (1952), 48-65.

Lemmens, H.J. (1898): Al-zalazil fi Suriah, Al-Mashreq, 1, 303-304 and 337-342, Beirut.

MALLET, R. (1853): Third report on the facts of earthquakes phenomena, Report of the 22nd Meeting of the British Association for the Advancement of Science, 1-176.

Mallet, R. and J.W. Mallet (1858): The earthquake catalogue of the British Association, Trans. Br. Ass. Adv. Sci., 1852 to 1858 , London.

ManetTi, Giannozzo (1457): De Terraemoto Libri Tres, Biblioteca Apostolica Vaticana, cod. Urbinate Lat. 5; cod. Palatino Lat. 1076, 1077 and 1604.

Montandon, F. (1953): Les Tremblements de Terre Destructeurs en Europe (Union Internationale de Secours, Genève), p. 160 séisme de 334.

Perrey, A. (1850): Mémoire sur les tremblements de terre ressentis dans la Péninsule Turco-Hellénique et en Syrie, Mém. Acad. R. Belg., 23, Bruxelles.

POIRIER, J.P., B.A. ROMANOWICZ and M.A. TAHER (1980): Large historical earthquakes and seismic risk in Northwest Syria, Nature, 285, 217-20.

Robert, L. (1978): Documents d'Asie Mineure V. Stèle funéraire de Nicomédie et séismes dans les inscriptions, Bull. Corresp. Helléniqque, 102, 395-408.

Russell, K.W. (1985): The earthquake chronology of Palestine and Northwest Arabia from the 2nd through the Mid-8th century A.D., Bull. Am. Sch. Oriental Res., 260, 37-59.

SiEBERG, A. (1932): Untersuchungen übar erdbeben und bruchscholenbau im Östlichen mittelmeergebiet, Denkschrifften der Medizinsch-Naturwissenschaft Gesellschaft zu Jena, 18, 161-273.

Swiss Reinsurance Company (1978): Atlas on Seismicity and Volcanism (October 1977, Switzerland).

TAHER, M.A. (1979): Corpus des textes arabes relatifs aux tremblements de terre et autres catastrophes naturelles de la conquête arabe au XII H/XVIII JC, Thesis de Doctorat d'Etat (Univ. Paris 1, Sorbonne), 2 vols.

TUCKER, W. (no date): The Effects of Earthquakes in the Medieval Islamic World (Dept. of History, Univ. of Arkansas, Fayeteville).

World Data Center for Sold EARTh Geophysics, Catalogue of Significant Earthquakes (2000 B.C.-1979 A.D.).

\section{Monographs}

Al-HaKeem, K. (1986): Analysis of the 1759 A.D. earthquake, Atomic Energy Commission of Syria, Internal Rep., Damascus.

Ambraseys, N.N. (1997): The earthquake of 1 January 1837 in Southern Lebanon and Northern Israel, Ann. Geofis., XL (4), 923-935.

Ambraseys, N.N. and M. BARAZANGi (1989): The 1759 earthquake in the Bekaa Valley: implications for earthquake hazard assessment in the Eastern Mediterranean region, J. Geophys. Res., 94, 4007-4013.

Ambraseys, N.N. and C.P. Melville (1988): An analysis of the Eastern Mediterranean earthquake of 20 May 1202, in History of Seismography and Earthquakes of the World, edited by W.H. LEE (Academic, San Diego, CA), 181-200.

Darawcheh, R., M.R. Sbeinati, C. Margottini and S. PAolini (2000): The 9 July 551 A.D. Beirut earthquake, Eastern Mediterranean region, J. Earthquake Eng., 4, 403-414.

GuYs, C.E. (1822): Le tremblement de terre qui a bouleversé la Haute-Syrie en Août 1822, Bull. Soc. Géogr., Paris, 1, 301-305 
Margaliot, M. (1960): The date of an earthquake at Taberias, Tarbiz, 29, 339-44.

TrainA, G. (1994): From Crimea to Syria. Re-defining the alleged historical earthquake of 63 B.C., Ann. Geofis., XXXVIII (5/6), 479-489.

TSAFRIR, Y. and G. FoERSTER (1992): The dating of the 'Earthquake of the Sabbatical year' of 749 C.E. in Palestine, Bull. Sch. Oriental African Stud., 55/ii, London, 231-235.

Vered, M. and H. Striem (1976): The Safad earthquake of 1.1.1837 and its implications on risk evaluation in Israel, Isr. A.E.C., No. IA-LD-1-105.

Other works

BARAZANGI, M. (1983): A summary of the seismotectonics of the Arabia region, in Assessment and Mitigation of Earthquake Risk in the Arab Region, edited by K. CIDINSKY and B. RouHBAn, Ass. Mit. Earthq. Ris. Arab Reg., UNESCO, 43-58.

Barazangi, M., D. Seber, T. Chaimov, J. Best and R. LITAK (1993): Tectonic Evolution of the Northern Arabian Plate in Western Syria (Kluwer Academic Publishers), 117-140.

Best, J., M. Barazangi, D. Al-SAad, T. SAWAF and A. GEBRAN (1990): Bouguer gravity trends and crustal structure of thePalmyride mountain belt and surrounding northern Arabian platform, Geology, 18, 1235-1239.

Brew, G., M. Barazangi, A.K. Al-Maleh and T. SawaF (2001): Tectonic and geological evolution of Syria, GeoArabia, 6, 537-616.

GARFUNKEL, Z., I. ZAK and R. FreUnd (1981): Active faulting in the Dead Sea rift, Tectonophysics, 80, 1-26.

Gomez, F., M. Meghraoui, A.N. Darkal, R. Sbeinati, R. Darawcheh, C. Tabet, M. Khawlie, M. Charabe, K. KHAIR and M. BARAZANGI (2001): Coseismic displacements along the Serghaya fault: an active branch of the Dead Sea fault system in Syria and Lebanon, J. Geol. Soc., 158, 405-408.

GRÜNTHAL, G. (Editor) (1993): European macroseismic scale 1992 (up-dated MSK-scale), Conseil de l'Europe, Cen. Européen Géodyn. Seismol., 7, Luxembourg.

IAEA (InTERnational ATOMic ENERgy Agency) (1979): Earthquakes and its associated topics in relation to nuclear power plant siting, IAEA Safety Series 50-SG-S1, Vienna.
IAEA (InTERNATIONAL ATOMIC ENERgy AgENCy) (1987): Methodology and procedures for compilation of historical earthquakes data, IAEA-TECDOC-434, Vienna.

KLENGEL, H. (1985): Syria Antiquity, translated by KASSEM Twer, Ministry of Culture, Damascus, 47-48 and 127

McBride, J., M. Barazangi, J. Best, D. Al-SaAd, T. SawaF, M. Al-Otri, and A. Gebran (1990): Seismic reflection structures of intracratonic Palmyride foldthrust belt and surrounding Arabian platform, Syria, Am. Assoc. Pet. Geol. Bull., 74, 238-259.

McClusky, S., R. Reilinger, S. Mahmoud, D. Ben SARi and A. TEALEB (2003): GPS constraints on Africa (Nubia) and Arabia plate motions, Geophys. J. Int., 155, 126-138.

Meghraoui, M., F. Gomez, R. Sbeinati, J. VAN DER WoERd, M. Mouty, A.N. Darkal, Y. Radwan, I. Layyous, H. Al-NajJar, R. Darawcheh, F. Hijazi, R. Al-GhazZi and M. BARAZANGI (2003): Evidence for 830 years of seismic quiescence from palaeoseismology, archaeoseismology and historical seismicity along the Dead Sea fault in Syria, Earth Planet. Sci. Lett., 210, 35-52.

PonIKARov, V.P (Editor) (1964): Tectonic Map of Syria, Scale 1:1000000 (Ministry of Industry, Damascus, Syria).

SBeinAti, M.R. (1993): Instrumental catalogue of earthquakes in Syria and adjacent areas from 1900 to 1993 , ICTP Res. Rep., Trieste (unpublished).

Shebalin, N.V. (1970): Intensity: on the statistical definition of the term, in Proc. X Ass. ESC, Leningrad, 3-11 September 1968 (Acad. Sci. USSR, Soviet Geophysical Committee, Moscow).

Shebalin, N.V. (1974): Principles and procedures of cataloguing, in Catalogue of Earthquakes, edited by N.V. SHEBALIN, V. KÁRNÍK and D. HADZIEVSKI, UNDP/UNESCO Survey of Seismicity of the Balkan Region (UNESCO, Skopje).

STUCCHI, M. (1994): Recommendations for the compilation of a European parametric earthquake catalogue, with special reference to historical records, in Materials of the CEC Project 'Review of Historical Seismicity in Europe', edited by P. Albini and A. Moroni, CNR Milano, 2, 181-190.

Wolseley Haig, LT.-Colonel SiR (1932): Comparative Tables of Muhammadan and Christian Dates (Luzac and Co., London).

(received December 19, 2003; accepted November 12, 2004) 